\begin{abstract}
UNIVERSIDADE DE SÃO PAULO
FACULDADE DE ECONOMIA, ADMINISTRAÇÃO E CONTABILIDADE DEPARTAMENTO DE ADMINISTRAÇÃO

PROGRAMA DE MESTRADO PROFISSIONAL EM EMPREENDEDORISMO
\end{abstract}

WALNEY BARBOSA DOS REIS

GESTÃO DE MARKETING EM MICRO E PEQUENAS EMPRESAS DESENVOLVEDORAS DE JOGOS DIGITAIS NO BRASIL 

FACULDADE DE ECONOMIA, ADMINISTRAÇÃO E CONTABILIDADE

WALNEY BARBOSA DOS REIS

GESTÃO DE MARKETING EM MICRO E PEQUENAS EMPRESAS DESENVOLVEDORAS DE JOGOS DIGITAIS NO BRASIL

Orientadora: Profa. Dra. Jane Aparecida Marques 
Prof. Dr. Vahan Agopyan

Reitor da Universidade de São Paulo

Prof. Dr. Fábio Frezatti

Diretor da Faculdade de Economia, Administração e Contabilidade

Prof. Dr. Moacir de Miranda Oliveira Junior

Chefe do Departamento de Administração

Prof. Dr. Marcelo Caldeira Pedroso

Coordenador do Programa de Mestrado Profissional em Empreendedorismo 


\title{
GESTÃO DE MARKETING EM MICRO E PEQUENAS EMPRESAS DESENVOLVEDORAS DE JOGOS DIGITAIS NO BRASIL
}

\begin{abstract}
Dissertação apresentada ao Programa de PósGraduação em Mestrado Profissional em Empreendedorismo do Departamento de Administração da Faculdade de Economia, Administração e Contabilidade da Universidade de São Paulo, como requisito parcial para obtenção do título de Mestre em Ciências.
\end{abstract}

Orientadora: Profa. Dra. Jane Aparecida Marques

\section{Versão Corrigida}

(versão original disponível na Biblioteca da Faculdade de Economia, Administração e Contabilidade) 
Autorizo a reprodução e divulgação total ou parcial deste trabalho, por qualquer meio convencional ou eletrônico, para fins de estudo e pesquisa, desde que citada a fonte.

Sistema de Geração Automática de Ficha Catalográfica, desenvolvido pelo Instituto de

Ciências Matemáticas e de Computação, da Universidade de São Paulo.

Reis, Walney Barbosa dos.

GESTÃO DE MARKETING EM MICRO E PEQUENAS EMPRESAS DESENVOLVEDORAS DE JOGOS DIGITAIS NO BRASIL / Walney Barbosa dos Reis. - São Paulo, 2021. $187 \mathrm{p}$.

Dissertação (Mestrado) - Universidade de São Paulo, 2021.

Orientador: Jane Aparecida Marques.

1. Gestão de Marketing. 2. Indústria de Jogos Digitais. 3. Indústrias Criativas. 4. Micro e Pequenas Empresas. 5. Análise Temática de Conteúdo. I. Universidade de São Paulo. Faculdade de Economia, Administração e Contabilidade. II. Título. 
FOLHA DE AVALIAÇÃO

Nome: REIS, WALNEY BARBOSA DOS

Título: Gestão de Marketing em Micro e Pequenas Empresas Desenvolvedoras de Jogos Digitais no Brasil

Dissertação apresentada ao Programa de Pós-Graduação em Mestrado Profissional em Empreendedorismo do Departamento de Administração da Faculdade de Economia, Administração e Contabilidade da Universidade de São Paulo, para obtenção do título de Mestre em Ciências.

Aprovado em: 30/06/2021

Banca Examinadora

Prof. Dr.: $\quad$ Delmar Galisi Domingues

Instituição: Universidade Anhembi Morumbi

Julgamento: Aprovado

Prof. Dr.: Otávio Bandeira De Lamônica Freire

Instituição: Universidade de São Paulo

Julgamento: Aprovado

Prof. Dr.: George Bedinelli Rossi

Instituição: Universidade de São Paulo

Julgamento: Aprovado 



\section{AGRADECIMENTOS}

Primeiramente, agradeço aos meus pais por todo apoio, suporte e amor que venho recebendo desde que nasci. Em um país marcado pela desigualdade, mas também pela esperança, é um grande privilégio poder contar com um ambiente familiar acolhedor e incentivador da busca pelo conhecimento e da superação das adversidades impostas por uma condição socioeconômica vulnerável. Até hoje, não sei de onde tiraram tanta força para nos criarem, eu e meus irmãos. Aliás, também agradeço muito aos meus irmãos pelas alegrias e momentos memoráveis que passamos (e continuamos passando) juntos.

Aterrissando no momento presente e a caminho do futuro, agradeço imensamente ao amor da minha vida, Renata, minha companheira de todas as horas e meu porto seguro, que me incentiva e me encoraja nas decisões mais difíceis e nos momentos mais críticos. Como disse o famoso astrônomo Carl Sagan, “diante da vastidão do tempo e da imensidão do Universo, é um imenso prazer para mim dividir um planeta e uma época com você".

Agradeço imensamente a todos os professores e pesquisadores com os quais tive o prazer de adquirir profundo conhecimento, mas também de aprender a valorizar a ciência, tão necessária nos tempos atuais. Tenho um especial carinho e admiração por todos, mas, por serem muitos, elejo, para representá-los, a minha querida orientadora, Profa. Dra. Jane A. Marques, mulher incrível que foi além do seu papel incontáveis vezes (ter me ajudado a realizar o sonho de estudar fora do país é só um exemplo dentre tantos), tendo se tornado uma verdadeira amiga e mentora de vida.

Além da minha orientadora, agradeço também a todos que viabilizaram na prática o desenvolvimento desse trabalho: aos professores membros da banca de Qualificação, Prof. Dr. Delmar Galisi Domingues e Profa. Dra. Graziella Maria Comini, pelas críticas e sugestões que enriqueceram e ditaram os novos rumos do trabalho; à Profa. Dra. Maria Cristina Caponero pela leitura atenta e sugestões valiosas; aos representantes das empresas analisadas, por terem concedido parte de seu precioso tempo; ao Paulo Rovai, meu amigo e colega de projetos de consultoria, fundamental no desenho do processo de convite e abordagem dos entrevistados; à Ana Correia, minha amiga e colega de classe, por ter viabilizado a transcrição das entrevistas em troca de um conhecimento estatístico que "supostamente" possuo; Ao Bruno Oliveira, meu amigo e parceiro de negócios, por revisar tecnicamente as definições e os conceitos de Publicidade Programática utilizados; à ABRAGAMES, pelo fornecimento de sua lista pública de empresas associadas e ao Raphael Dias, que embora não o conheça pessoalmente, deixou 
um legado na Internet denominado Mapa das Indústrias de Jogos, do qual também extraí uma enorme lista de contatos de empresas brasileiras de jogos digitais.

Não poderia deixar de agradecer a todos os gamers do Brasil e aos meus amigos gamers que fiz ao longo da vida, que sem dúvida tiveram participação fundamental no meu processo de engajamento com o tema e de vivência em uma comunidade única, compartilhando momentos especiais e irreplicáveis. Dentre alguns nomes, cito os mais contemporâneos de um clã (uma família, melhor dizendo) que quase todas as noites reúnem-se comigo para jogarmos Call of Duty: Douglas, Edson, Edu, Vini, Panda, Riva, Silvio e Wega.

Por fim, agradeço à Universidade de São Paulo, que mais uma vez me acolheu por meio da Faculdade de Economia, Administração e Contabilidade, proporcionando um Programa de Mestrado inesquecível, essencial ao meu desenvolvimento empreendedor, com professores, colaboradores e colegas com os quais gostaria de continuar tendo contato até o fim da minha vida. 
Para mim, é muito melhor compreender o Universo como ele realmente é do que persistir na ilusão, por mais satisfatório e reconfortante que seja.

Carl Sagan 



\section{RESUMO}

REIS, Walney Barbosa dos. Gestão de Marketing em Micro e Pequenas Empresas Desenvolvedoras de Jogos Digitais no Brasil. 2021. 187 f. Dissertação (Mestrado Profissional em Empreendedorismo) - Faculdade de Economia, Administração e Contabilidade, Universidade de São Paulo, São Paulo, 2021.

A Indústria de Jogos Digitais é um componente de destaque das Indústrias Criativas, especialmente pelo fato de os níveis de faturamento e o ritmo de crescimento superarem os das Indústrias Cinematográfica e Musical. Os videogames evoluíram com o tempo e passaram a fazer parte da rotina de bilhões de pessoas, de diferentes faixas etárias e nacionalidades, para fins de entretenimento ou outros. No Brasil, há um ecossistema de agentes responsáveis pelo desenvolvimento, publicação, promoção, distribuição e propagação de informações como parte de uma complexa cadeia de valor, mas caracterizado por limitações associadas ao porte e a diversos fatores de suas instituições desenvolvedoras, constituídas, em sua maioria, por micro e pequenas empresas. Parte dessas limitações diz respeito à mão de obra com um histórico acadêmico e experiências profissionais distantes do mundo dos negócios, culminando na inabilidade de elaboração de estratégias eficientes de gestão, especificamente de gestão de marketing. Sendo assim, o presente estudo teve como objetivo elencar, descrever e qualificar grandes desafios que as micro e pequenas empresas brasileiras desenvolvedoras de jogos digitais precisam superar para melhorar sua gestão de marketing. Para atingir tal objetivo, empreendeu-se uma pesquisa de caráter exploratório, de natureza qualitativa, baseada na coleta e análise de dados primários obtidos por meio de entrevistas em profundidade realizadas com 10 (dez) representantes de micro e pequenas empresas brasileiras de jogos digitais e com 2 (duas) de maior porte, utilizadas como base de comparação. Os dados coletados foram analisados sob os preceitos da análise temática de conteúdo, que segmentou, padronizou e quantificou o conteúdo de modo a viabilizar interpretações qualitativas a partir de uma base objetiva e menos dependente de conceitos preliminares do autor. Tais técnicas viabilizaram um entendimento do histórico e das características, da oferta e dos processos de produção, da visão estratégica de marketing e de um diagnóstico da gestão de marketing e da inteligência de marketing atuais das empresas em questão. Como resultado, foi possível elencar, descrever e qualificar 5 (cinco) grandes desafios de gestão de marketing, a saber: 1) Ir além do "P" de Promoção e passar a contemplar os outros "Ps" de marketing; 2) Engajar e manter a base de jogadores via sistemas digitais abundantes de gestão de relacionamento com os clientes; 3 ) Impactar mais eficientemente os públicos potenciais, visto que a publicidade online fornece recursos e possibilidades pouco exploradas; 4) Converter dados em inteligência de marketing, transformando-os em informações valiosas; e 5) Atender aos anseios do mercado sem perder a essência, ou seja, sem que isso interfira em um posicionamento artístico, de qualidade ou social da marca. Tais ações foram consideradas desafios, pois envolvem o rompimento de barreiras estruturais como falta de recursos financeiros, conhecimento, processos, pessoas, suporte público e privado, dentre outras. Por se tratar de uma pesquisa de identificação de problemas, procurou-se abrir o leque de possibilidades de estudos futuros e de desenvolvimento mercadológico.

Palavras-chave: Gestão de Marketing. Indústria de Jogos Digitais. Indústrias Criativas. Micro e Pequenas Empresas. Análise Temática de Conteúdo. 


\begin{abstract}
REIS, Walney Barbosa dos. Marketing Management in Micro and Small Development Companies of Digital Games in Brazil. 2021. 187 p. Dissertation (Professional Master in Entrepreneurship) - Faculdade de Economia, Administração e Contabilidade, Universidade de São Paulo, São Paulo, 2021.
\end{abstract}

The digital games industry is a prominent component of the creative industries, especially since it's levels of revenue and growth rates surpass those of the film and music industries. Video games have evolved over time and become routine for billions, of different age groups and nationalities, both for entertainment and other purposes. In Brazil, there is an ecosystem of agents responsible for the development, publication, promotion, distribution, and dissemination of information as part of a complex value chain, but it is characterized by limitations associated with the size and other characteristics of development companies, which are mainly micro and small businesses. Part of these limitations concern the gap between the workforce academic/professional experiences and the business world, culminating in the inability to develop efficient management strategies, specifically marketing management. Therefore, this study aims to list, describe, and qualify big challenges Brazilian micro and small game developers need to overcome to improve their marketing management. To fulfill this objective, an exploratory research of a qualitative nature was undertaken, based on the collection and analysis of primary data obtained through in-depth interviews, conducted with 10 (ten) representatives of micro and small Brazilian digital gaming enterprises and with 2 (two) larger ones as a basis for comparison. The data collected were analyzed under the precepts of thematic content analysis, which segmented, standardized, and quantified the content to enable qualitative interpretations from an objective basis and less dependence on the author's preliminary concepts. Such techniques enabled an understanding of the history and characteristics, the offer and its production processes, the strategic marketing vision, and current marketing management and marketing intelligence diagnosis of such enterprises. As a result, it was possible to list, describe and qualify 5 (five) big marketing management challenges, namely: 1) Going beyond the "P" of "promotion" and starting to contemplate the other "Ps" of marketing; 2) Engaging and maintaining the player base via abundant digital customer relationship management systems; 3) Impacting potential audiences more efficiently, since online advertising provides little-explored resources and possibilities; 4) Converting data into marketing intelligence, transforming it into valuable information; and 5) Meeting the market's desires without losing the essence, that is, without interfering with an artistry, quality or social positioning of the brand. Such actions were considered challenges, as they all involve breaking down structural barriers, such as lack of financial resources, knowledge, processes, people, public and private support, among others. As research to identify problems, it sought to open a range of possibilities for future studies and business opportunities.

Keywords: Marketing Management. Digital Games Industry. Creative Industries. Micro and Small Enterprises. Thematic Content Analysis. 


\section{LISTA DE FIGURAS}

Figura 1 - Cadeia de valor da Indústria de Jogos Digitais...................................................29

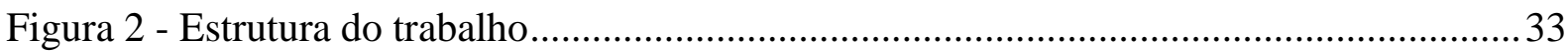

Figura 3 - Comparação entre o filme Avatar e o videogame GTA V ......................................35

Figura 4 - Função de realidade aumentada do jogo Pokémon Go............................................ 41

Figura 5 - Mercado global de videogames por região ........................................................... 43

Figura 6 - Volume global de jogadores por região ............................................................... 44

Figura 7 - Processo de estruturação do referencial teórico...................................................... 48

Figura 8 - Estratégia de Marketing e o Mix de Marketing .....................................................56

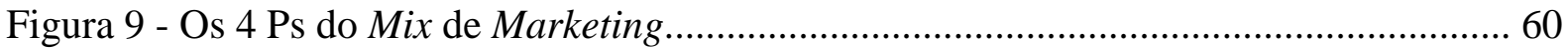

Figura 10 - Diferenças entre tipos de mídia no meio online ................................................. 72

Figura 11 - Principais componentes da Publicidade Programática ......................................... 73

Figura 12 - Marketing de Relacionamento, CRM e Gestão de Clientes ................................. 75

Figura 13 - Características distintivas das Indústrias Criativas ............................................... 79

Figura 14 - Fluxograma das principais decisões metodológicas da dissertação....................... 86

Figura 15 - Termos-chave de busca para trabalhos de base para o instrumento ......................94

Figura 16 - Processo de seleção e de filtragem das empresas do mailing .............................. 101

Figura 17 - Ciclo de análise utilizando o software NVivo ................................................... 113

Figura 18 - Estrutura-base da análise temática de conteúdo ................................................. 119

Figura 19 - Histórico geral da trajetória das empresas analisadas........................................ 120

Figura 20 - Nuvem de palavras nos segmentos de texto marcados como "desafios" ............122

Figura 21 - Árvore de palavras ramificadas pela palavra-tronco "não" ................................ 123

Figura 22 - Processo geral de produção de jogos das empresas analisadas ...........................126

Figura 23 - Nuvem de palavras com termos-chave de todo o conteúdo transcrito ................ 136

Figura 24 - Dendrograma da análise de cluster por similaridade de palavras ........................ 140

Figura 25 - Inspiração para criação do videogame Pac Man ................................................. 145

Figura 26 - Exemplo de conteúdo fornecido pelo SEBRAE em formato acessível ............... 158 



\section{LISTA DE TABELAS}

Tabela 1 - Volumetria e codificação dos dados avaliados

Tabela 2 - Volumetria da segmentação temática do conteúdo de gestão de marketing 138

Tabela 3 - Temas mais abordados em gestão de marketing ao longo das fases de

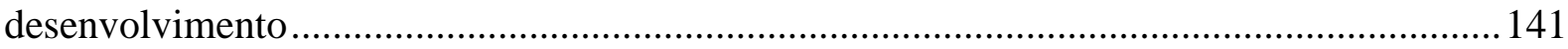

Tabela 4 - Subtemas mais abordados em gestão de marketing ao longo das fases de

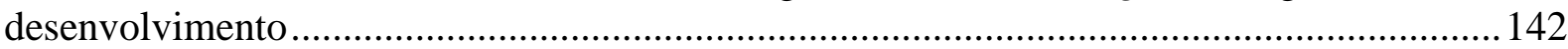

Tabela 5 - Coeficientes do conteúdo das entrevistas outliers em relação às entrevistas regulares

Tabela 6 - Temas mais abordados em inteligência de marketing ao longo das fases de desenvolvimento 



\section{LISTA DE QUADROS}

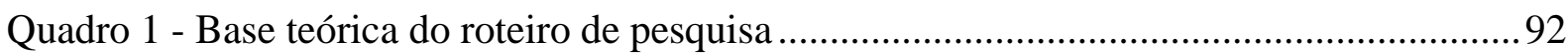

Quadro 2 - Procedimentos de busca e de filtragem dos trabalhos ...........................................94

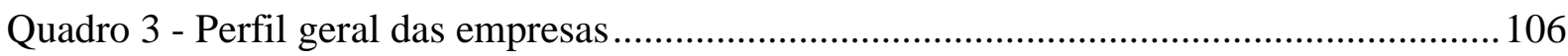

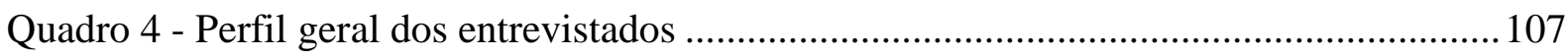

Quadro 5 - Grau de escolaridade dos entrevistados ............................................................ 108

Quadro 6 - Tipos de jogos desenvolvidos pelas empresas analisadas .................................. 125

Quadro 7 - Apostas de geração de receita das empresas analisadas ...................................... 127

Quadro 8 - Resultados da análise transversal sintética do conteúdo ......................................130 



\section{LISTA DE ABREVIATURAS E SIGLAS}

\begin{tabular}{|c|c|}
\hline ABRAGAMES & Associação Brasileira das Desenvolvedoras de Jogos Eletrônicos \\
\hline AMA & American Marketing Association \\
\hline BNDES & Banco Nacional de Desenvolvimento Econômico e Social \\
\hline B2B & Business to Business \\
\hline CD & Compact Disc (Disco Compacto) \\
\hline CD-ROMs & $\begin{array}{l}\text { Compact Disc Read-Only Memory (Disco Compacto com Memória apenas } \\
\text { de Leitura) }\end{array}$ \\
\hline CEO & Chief Executive Officer (Diretor Executivo) \\
\hline CRM & $\begin{array}{l}\text { Customer Relationship Management (Gestão de Relacionamento com o } \\
\text { Cliente) }\end{array}$ \\
\hline EP & Entrevista em profundidade \\
\hline FPS & First Person Shooter \\
\hline DCMS & Department for Digital, Culture, Media \& Sport \\
\hline DLCs & Downloadable contents \\
\hline DMP & Data Management Platform \\
\hline DSP & Demand Side Platform \\
\hline DVD & Digital Video Disk (Disco Digital de Vídeo) \\
\hline LGBT & Lésbicas, Gays, Bissexuais e Transgêneros \\
\hline LOL & League of Legends \\
\hline MINC & Ministério da Cultura \\
\hline MMO & Massive Multiplayer Online (Multijogadores online em massa) \\
\hline MPEs & Micro e pequenas empresas \\
\hline $\mathbf{P C}$ & Personal Computer \\
\hline PO & Product Owner \\
\hline ROI & Return on Investment (Retorno sobre o Investimento) \\
\hline $\mathbf{R P}$ & Relações Públicas \\
\hline RPG & Role-Playing Game \\
\hline SEBRAE & Serviço Brasileiro de Apoio às Micro e Pequenas Empresas \\
\hline USP & Unique Selling Proposition \\
\hline WoW & World of Warcraft \\
\hline
\end{tabular}





\section{APRESENTAÇÃO}

Estudar qualquer indústria, incluindo a de jogos digitais, impõe desafios e perspectivas de múltiplas naturezas: um cientista da computação pode trabalhar com as implicações tecnológicas associadas a ela; um sociólogo pode se interessar pelas dinâmicas sociais de ambientes digitais; um psicólogo pode querer compreender os efeitos dos jogos no processo de aprendizagem etc. Dentre as várias abordagens possíveis em relação ao fenômeno em questão, o autor optou por analisá-lo sob a perspectiva da gestão de marketing, adotada por micro e pequenas empresas, com base nos fatores descritos a seguir. A experiência e o relacionamento do autor com o fenômeno a ser estudado serão abordados com o propósito de evoluir alguns aspectos da atividade empreendedora nacional.

O autor é graduado em Marketing pela Escola de Artes, Ciências e Humanidades da Universidade de São Paulo (EACH-USP) e, há 7 (sete) anos, vem atuando no ramo de Ciência de Dados aplicada a Marketing, com o propósito de auxiliar tomadores de decisão em estratégias e ações de marketing com base no uso extensivo de dados.

A jornada profissional e acadêmica do autor vem sendo moldada por problemas e soluções ao redor do campo de conhecimento de Marketing, o que se enquadrou perfeitamente com visão do Programa de Mestrado Profissional em Empreendedorismo da Universidade de São Paulo (FEA-USP), que preza tanto pelo avanço científico quanto pelas práticas empreendedoras das organizações, incluindo a vivência prática de seus alunos e pesquisadores no âmbito profissional. A partir do Programa, "busca-se analisar as atividades, características, efeitos sociais e os métodos de suporte utilizados para facilitar a atividade empreendedora..." (FEA-USP, 2020).

Essa vivência acadêmica e profissional possibilitou ao autor ter contato com empreendedores e profissionais da Indústria de Jogos Digitais, testemunhando dificuldades impostas às micro e pequenas empresas, tais como o financiamento e o relacionamento com instâncias governamentais, mas mais especificamente com os problemas completa ou parcialmente relacionados a marketing, a saber: atração e retenção de clientes (jogadores); promoção dos jogos desenvolvidos; relacionamento com a base de jogadores; precificação de itens virtuais; formato e eficiência de criativos entre outros.

Numa conversa informal, um dos empreendedores da rede de contato do autor chegou a afirmar que "toda vez que é lançado um jogo que obtém sucesso e outro que fracassa, não se sabe exatamente os motivos que explicam o êxito de um e o fracasso de outro". Essa falta de conhecimento acerca dos fatores que levam um jogo ao sucesso ou ao fracasso poderia ser 
superada ao serem incorporados conhecimentos, rotinas e processos de gestão de marketing a níveis estratégicos, táticos e operacionais de tais empresas.

O trabalho, de forma geral, foi escrito pensando em três públicos: pessoas que entendem de jogos digitais, mas não entendem de marketing; pessoas que entendem de marketing, mas não entendem de jogos digitais; e pessoas que não entendem de ambos os assuntos, mas nutrem o interesse genuíno pela aquisição desse conhecimento. Desta forma, optou-se por um conteúdo que transitasse entre temas mais básicos e complexos, com base científica, mas que não deixasse de comtemplar a perspectiva mercadológica aplicada.

Portanto, somam-se ao conjunto de fatores e motivações para a elaboração do presente trabalho: o respeito à ciência e a busca por resultados confiáveis derivados de seu método, as necessidades práticas do ecossistema empreendedor e empresarial da indústria em território nacional e, sem dúvida alguma, o fascínio e a paixão do autor pelas possibilidades de imersão que esse tipo de tecnologia é capaz de proporcionar. 


\section{SUMÁRIO}

1. INTRODUÇÃO

2. CONTEXTUALIZAÇÃO DO MERCADO E DA INDÚSTRIA DE JOGOS

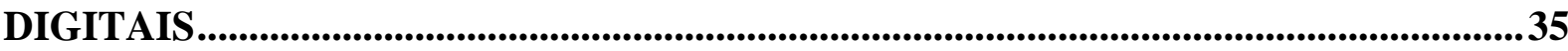

2.1 CARACTERÍSTICAS E TENDÊNCIAS ATUAIS DA INDÚSTRIA ..................... 37

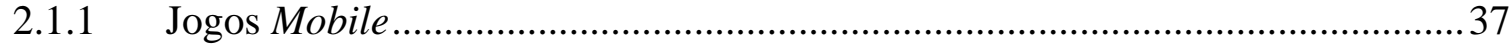

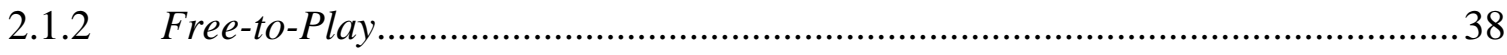

2.1.3 Massive Multiplayer Online - MMO ................................................................. 39

2.1.4 Ampliação do Público Gamer .............................................................................. 40

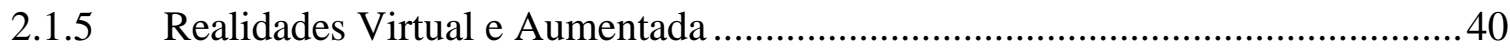

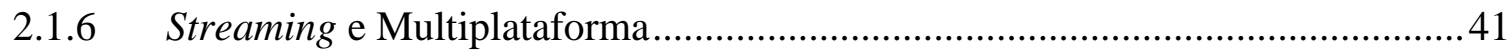

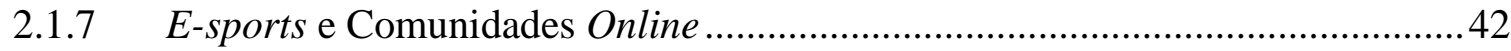

2.1.8 Exploração das Emoções e Incremento da Experiência ...................................... 42

2.2 MERCADO NACIONAL E INTERNACIONAL ................................................. 43

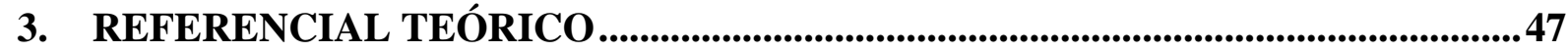

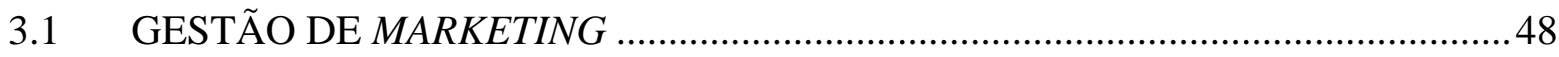

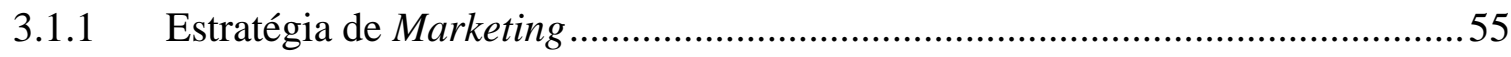

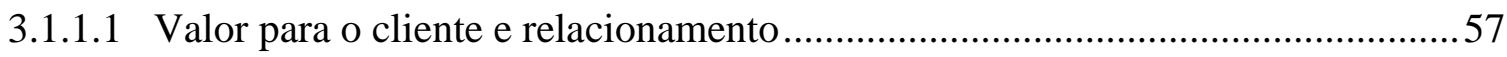

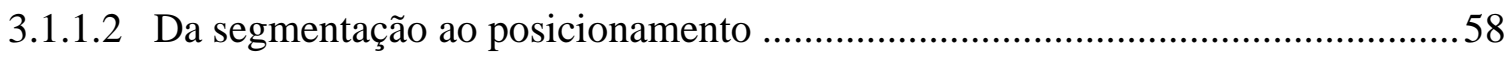

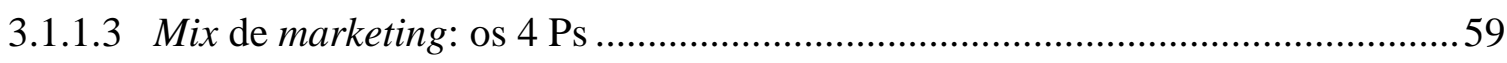

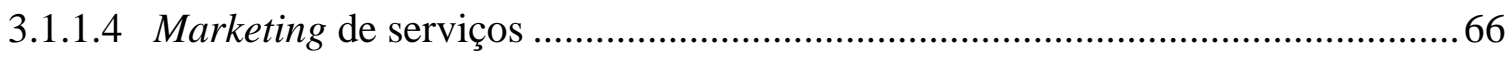

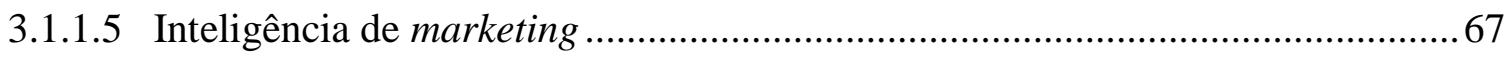

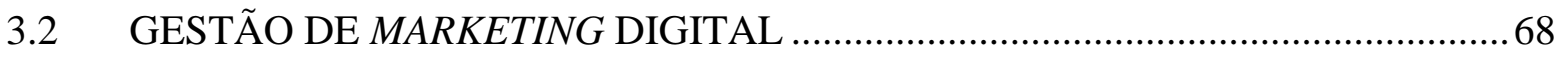

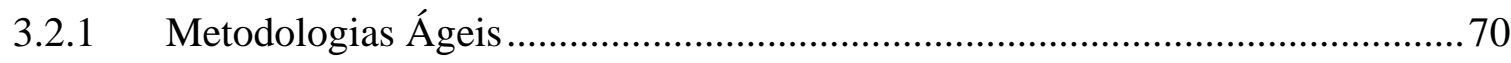

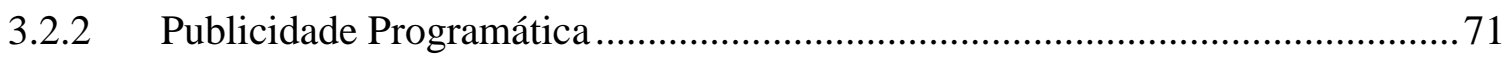

3.2.3 Gestão de Relacionamento com o Cliente - CRM ............................................ 74

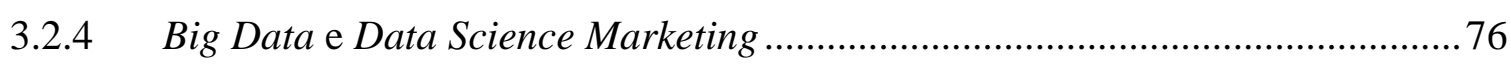

3.3 GESTÃO DE MARKETING NAS INDÚSTRIAS CRIATIVAS .............................77

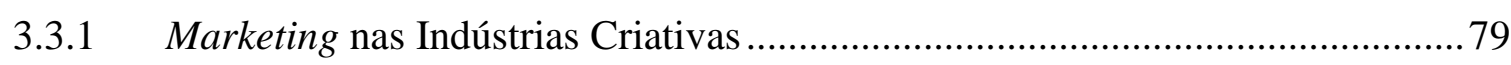

3.3.2 Marketing em Empresas de Jogos Digitais ................................................... 81

3.3.3 Marketing em MPEs de Jogos Digitais ...................................................... 82

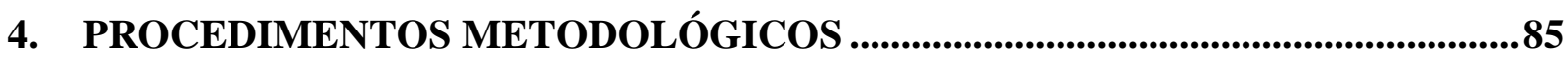

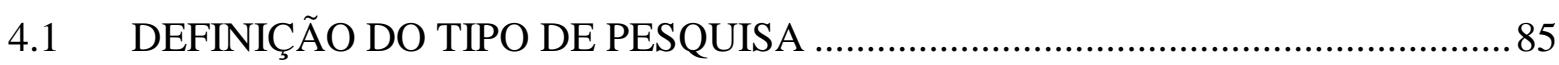

4.2 CRITÉRIOS DE SELEÇÃO E TAMANHO DA AMOSTRA.................................8

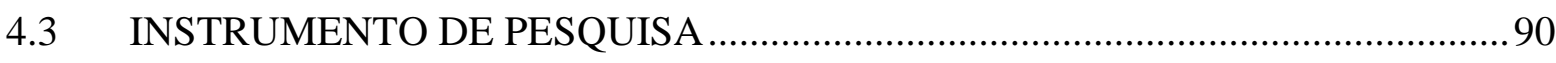




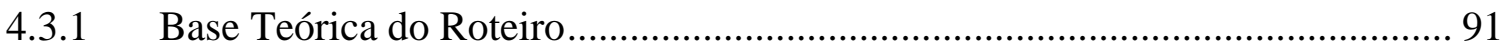

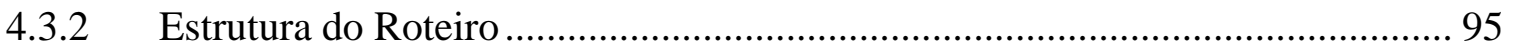

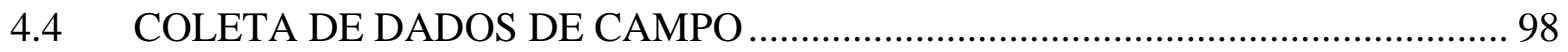

4.4.1 Processo de Construção e Gestão do Mailing de Entrevistados ......................... 99

4.4.2 Abordagem dos Potenciais Entrevistados .......................................................... 101

4.4.3 Pré-teste e Execução das Entrevistas ................................................................. 103

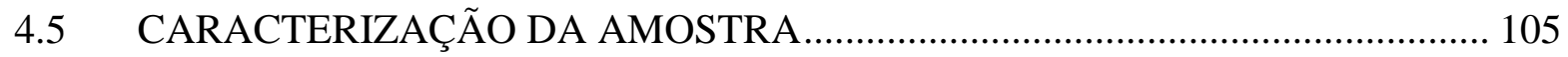

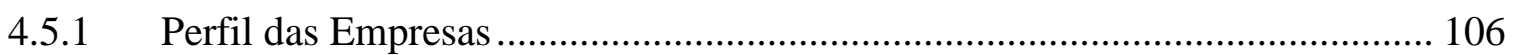

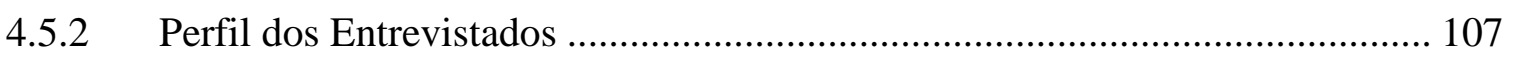

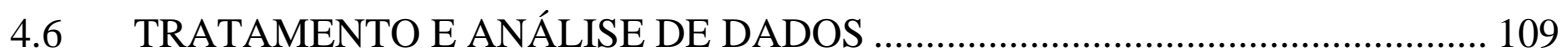

4.6.1 Processo de Análise Temática do Conteúdo ...................................................... 110

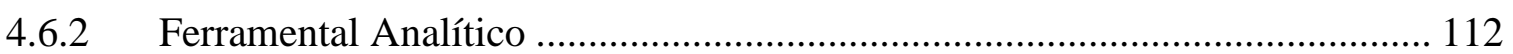

4.6.3 Técnicas de Análise de Dados ............................................................................ 114

4.6.4 Volumetria e Codificação dos Dados Avaliados ........................................... 115

5. DISCUSSÃO DOS RESULTADOS ......................................................................... 119

5.1 HISTÓRICO E CARACTERÍSTICAS DAS EMPRESAS.................................... 120

5.2 NATUREZA E PROCESSOS ATRELADOS À OFERTA ................................... 124

5.3 GESTÃO DE MARKETING DAS EMPRESAS …........................................... 128

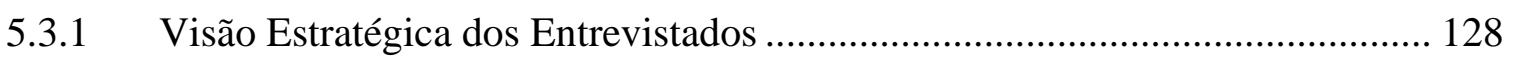

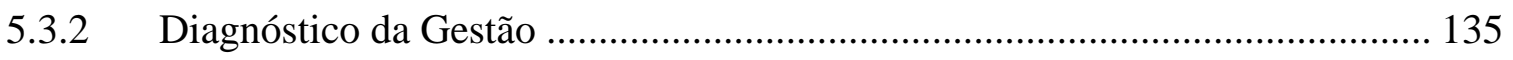

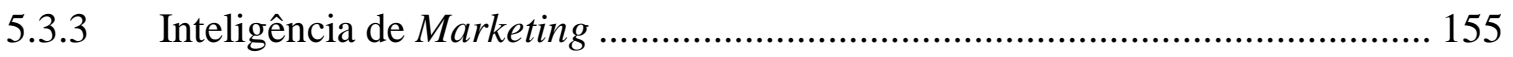

5.4 GRANDES DESAFIOS DA GESTÃO DE MARKETING ................................... 157

5.4.1 Desafio 1: Ir além do "P” de Promoção ............................................................ 157

5.4.2 Desafio 2: Engajar e Manter a Base de Jogadores .......................................... 159

5.4.3 Desafio 3: Impactar Mais Eficientemente os Públicos Potenciais ................... 160

5.4.4 Desafio 4: Converter Dados em Inteligência de Marketing ............................. 161

5.4.5 Desafio 5: Atender aos Anseios do Mercado sem Perder a Essência ............... 162

6. CONCLUSÕES, LIMITAÇÕES E ESTUDOS FUTUROS ..................................... 165

REFERÊNCIAS BIBLIOGRÁFICAS ........................................................................ 169

APÊNDICE 1: VERSÃO FINAL DO ROTEIRO DE ENTREVISTAS........................... 181

APÊNDICE 2: CARTA-BASE DE CONVITE ENVIADA À AMOSTRA

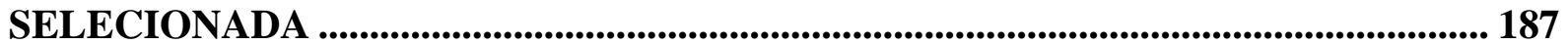




\section{INTRODUÇÃO}

Marketing, de forma holística, é um importante componente de gestão (administrativo) e de visão (que lida com ideais) de uma empresa. É considerado o "processo pelo qual as empresas criam valor para os clientes e constroem fortes relacionamentos para capturar seu valor em troca" (KOTLER; ARMSTRONG, 2007, p. 4). Valor é entendido, por um lado, como o suprimento de uma necessidade do cliente e, por outro, como a geração de lucro, reconhecimento ou obtenção do propósito da empresa (KOTLER; ARMSTRONG, 2007).

Marketing pode, então, ser entendido como um fator crucial de sobrevivência de uma empresa (KOTLER; ARMSTRONG, 2007), sendo uma das áreas que mais recebem atenção por parte dos sócios de empresas brasileiras de jogos digitais, devido ao baixo número de profissionais especializados em seu quadro de colaboradores e por ser decisivo na geração de receita, de acordo com o Segundo Censo da Indústria Brasileira de Jogos Digitais ${ }^{1}$ do Ministério da Cultura (MINC, 2018).

No entanto, mais atenção não se converte automaticamente em maiores investimentos ou maior conhecimento na área, tanto que, geralmente, há no máximo 9,8\% de colaboradores dedicados a esse tipo de atividade - somados às atividades de vendas. Nesse cenário, há uma conversão prática de nenhum ou 1 (um) a cada 10 (dez) colaboradores - número próximo à média nacional (MINC, 2018).

O desconhecimento advindo de um histórico acadêmico e as experiências profissionais mais distantes do mundo dos negócios culminam na inabilidade dos sócios das empresas em elaborarem estratégias de gestão, podendo "deixar áreas como a de publicidade ou a de marketing sem investimento real. A baixa receita e o limitado capital de giro fazem com que essas sejam áreas preteridas em favor do desenvolvimento do jogo digital em $\mathrm{si}^{2}$ " (MINC, 2018, p. 162).

Observa-se que, nos últimos anos, a Academia vem dando cada vez mais atenção aos videogames como objeto de estudo devido ao seu potencial educativo (GRIFFITHS, 2002;

\footnotetext{
${ }^{1}$ Indústria Brasileira de Jogos Digitais é a nomenclatura oficial utilizada pelo Ministério da Cultura (2018) para o setor nacional de videogames. O termo videogame será utilizado, portanto, para se referir aos produtos que movem a indústria nacional e a indústria global, definido em maiores detalhes por Esposito (2005) na seção 3.1.1.3 - Mix de Marketing: os 4Ps. Tal definição assemelha-se à de Jogos Digitais estabelecida pelo Ministério da Cultura (2018, p. 298), sendo, portanto, ambos tratados como sinônimos em boa parte do trabalho, com importante diferenciação em sua forma de distribuição: distribuição digital (via downloads, por exemplo) ou distribuição física (via compra de discos compactos com o jogo digital ou videogame instalado, por exemplo).

${ }^{2} \mathrm{O}$ relatório baseia-se nas características da mão de obra, sua distribuição entre funções e nas declarações dos entrevistados em relação às atividades mencionadas, não chegando a especificar numericamente o volume ou as proporções de investimento.
} 
MOLINS-RUANO et al., 2014; GONZÁLEZ-GONZÁLEZ; BLANCO-IZQUIERDO, 2012; SERRANO-LAGUNA et al., 2014), à sua função em tratamentos ou na recuperação de pacientes na área da saúde (DURKIN, 2010; VILLANI et al., 2018; LU et al., 2013; RAHMANI; BOREN, 2012) ou ao seu papel social em temáticas como hiper sexualização, violência, consumo, entre outras (JENSON; CASTELL, 2013; HARTMANN, 2017; WATKINS; MOLESWORTH, 2012).

Os estudos que abordam os videogames como negócio, sob perspectiva empreendedora, de indústria ou de empresa, são pouco numerosos, destacando-se os de Gil e Warzynski (2015) e os de Burger-Helmchen (2008). Raros são também os estudos acerca do papel das estratégias e das atividades de marketing nessas organizações, destacando-se os de Waller (2015) e os de Seo (2013).

Em termos do cenário brasileiro, a situação não é muito distinta, pois a Academia nacional conta apenas com raros trabalhos direcionados à temática como o de Moser (2005) e, mesmo assim, eles apenas tangenciam o tema central da presente dissertação em relação ao propósito, ao contexto ou à atualização, o que, portanto, justifica a realização da mesma.

A Indústria Brasileira de Jogos Digitais, assim como a indústria internacional, é bastante complexa e composta por uma série de atores que se interacionam e cooperam na geração e na entrega de valor ao consumidor final, conforme ilustra a Figura 1 a seguir.

A indústria de jogos digitais depende de uma série de agentes para entregar (distribuidores), promover (relações públicas e agências de publicidade) e disponibilizar informações (mídia especializada ou não especializada), além de desenvolver e publicar o jogo em si (os desenvolvedores e os fornecedores de mão de obra, ativos artísticos ou tecnologia em forma de serviços) para entregar valor ao consumidor final.

A complexidade aumenta na medida em que possam existir diferentes configurações e tipos de empresas presentes no mercado. Uma empresa pode ser ao mesmo tempo desenvolvedora e publicadora, enquanto terceiriza trabalhos de arte; outra empresa pode terceirar tudo, ficando responsável somente pela programação do jogo em si etc. São possíveis diversas combinações imagináveis.

Desse cenário emerge a definição da população de interesse ou o universo da pesquisa, que poderia ser a Indústria Brasileira de Jogos Digitais como um todo (desenvolvedores, publicadores, distribuidores, jornalistas etc.), ou um tipo de agente específico (desenvolvedores, por exemplo), tornando-se necessário especificar ao máximo esses agentes ou os conjuntos de agentes, assim como definir o tamanho da amostra que representará esse universo. 
Figura 1 - Cadeia de valor da Indústria de Jogos Digitais ${ }^{3}$

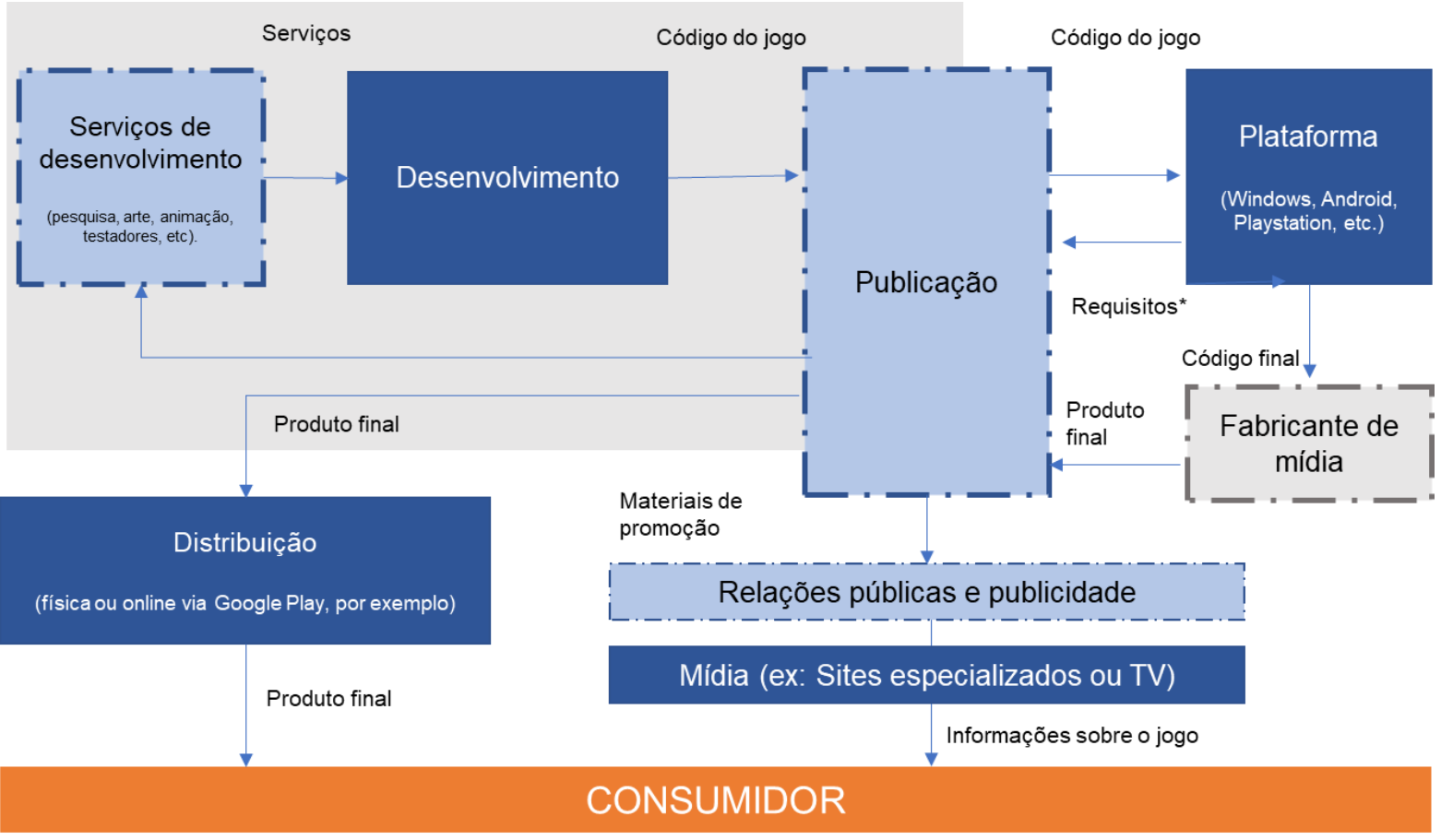

Fonte: Elaborada pelo autor, adaptada de Tucker (2016, p. 2), em função do contexto da dissertação.

A partir da cadeia de valor ilustrada na Figura 1 e dos conceitos de marketing apresentados no Capítulo 3. REFERENCIAL TEÓRICO foi possível deduzir as atividades de marketing presentes em toda a cadeia produtiva da indústria: o varejista (ou a loja online) pode ter seu foco nas vendas do título, lançando mão de táticas de precificação e de execução de promoções de "queima de estoque"; ou a publicadora que pode estar preocupada com a estratégia de distribuição do jogo, tomando decisões sobre os formatos (mídias físicas ou digitais) e o acesso (canais de distribuição online ou offline).

Apesar de desejável que se tenha contato e que se extraiam dados de todos os agentes da indústria que possam executar atividades de marketing, permitindo uma interpretação com múltiplas perspectivas, os recursos financeiros, humanos e técnicos disponíveis não são suficientes para tal, o que exige a delimitação do universo de pesquisa a um tipo de agente específico: empresas desenvolvedoras de jogos digitais.

\footnotetext{
${ }^{3}$ As funções que se apresentam tracejadas em azul podem ser incorporadas pela empresa desenvolvedora ou terceirizada a outras empresas. Distribuição, Mídia e Plataforma também são possibilidades de incorporação quando uma empresa proprietária da plataforma (Microsoft, por exemplo) assume o papel de desenvolvimento, mas são menos comuns. A função Fabricante de mídia (tracejada em cinza) pode não existir quando a distribuição é exclusivamente online (via download, por exemplo).

"Requisitos*" é um entregável adicionado, não presente no original, com base no conhecimento do autor em contato com profissionais e empresas da indústria.
} 
O desenvolvedor é definido oficialmente pelo Ministério da Cultura do Brasil (2018) como uma pessoa ou um estúdio que desenvolve, total ou parcialmente, um projeto de jogo digital. Uma empresa desenvolvedora de jogos digitais seria, então, uma organização individual ou coletiva que se responsabiliza por suas atividades e pelas atividades de terceiros, pela junção de todas as partes e pela composição da versão final do jogo. Elas são, em sua maioria, micro e pequenas empresas, como detalhado no subitem 2.2 MERCADO NACIONAL E INTERNACIONAL.

Dessa forma, é possível afirmar que há uma grande concentração de risco comercial em um só agente e pressupõe-se que o(a) desenvolvedor(a) seja um dos maiores - senão o(a) maior interessado(a) no sucesso de vendas, de crítica e de público de um jogo. Esse foi, então, o principal motivador para a escolha das micro e pequenas empresas desenvolvedoras de jogos digitais como o grupo que compõe o universo da pesquisa.

Guardando pertinência com a fase e com o contexto no qual essas empresas encontramse, o presente estudo visa a responder ao seguinte problema de pesquisa: "Como micro e pequenas empresas desenvolvedoras brasileiras de jogos digitais conduzem sua gestão de marketing?"

Para responder a essa pergunta, estabelecemos como objetivo principal para a presente pesquisa: "elencar, descrever e qualificar grandes desafios que as micro e pequenas empresas desenvolvedoras brasileiras de jogos digitais precisam superar para melhorar sua gestão de marketing".

Também foram estabelecidos os seguintes objetivos específicos para extração de informações-chave, com base na visão dos representantes das empresas:

a) Entender a realidade por meio do perfil das empresas e dos entrevistados, como ponto de partida da análise;

b) Compreender distintas visões estratégicas no que diz respeito à gestão de marketing, levando-se em consideração seu histórico e sua situação atual;

c) Realizar um diagnóstico das formas de gestão de marketing e seus principais aspectos dentro de seu contexto operacional e mercadológico.

Para a Academia, a presente dissertação traz, portanto, uma nova perspectiva e um novo enfoque das organizações brasileiras de jogos digitais com o propósito de evoluir o entendimento acerca de suas atividades de marketing, especificamente no que tange à gestão de marketing de micro e pequenas empresas brasileiras desenvolvedoras de jogos digitais que compõem nacionalmente o segmento das Indústrias Criativas (MINC, 2018). 
Para a Indústria Nacional, a presente dissertação apresenta os principais desafios de um ramo de atividade ao mesmo tempo necessário e desafiador para as micro e pequenas empresas. Espera-se que os resultados e as discussões levantadas auxiliem os empreendedores de jogos digitais e da Indústria Criativa de um modo geral a compreenderem melhor suas limitações e potencialidades, facilitando o desenvolvimento de soluções ou a busca por ajuda especializada nesse campo de atuação.

Por fim, para a sociedade de modo geral, acredita-se que essa dissertação seja uma pequena peça de auxílio no desenvolvimento dos ecossistemas econômico (com mais empresas nacionais de destaque), político (com mais proposições e suporte das autoridades competentes) e cultural (viabilizando formas de expressão via jogos digitais com características, valores e traços criativos tipicamente brasileiros).

Para tanto, o trabalho apresenta-se estruturado em seis capítulos, conforme demonstra a Figura 2 a seguir. No Capítulo 1. INTRODUÇÃO, é feita uma breve introdução e são apresentados o problema de pesquisa, os objetivos principal e específicos e a justificativa.

No Capítulo 2. CONTEXTUALIZAÇÃO DO MERCADO E DA INDÚSTRIA DE JOGOS DIGITAIS, são apresentadas as tendências, características e dados de mercado para uma melhor compreensão dos termos, situação e dinâmicas específicas da indústria nacional e internacional.

No Capítulo 3. REFERENCIAL TEÓRICO, são apresentados os conceitos de base para as análises que propiciem uma adequada resposta ao objetivo central. São eles: Gestão de Marketing, Gestão de Marketing Digital e Gestão de Marketing nas Indústrias Criativas.

No Capítulo 4. PROCEDIMENTOS METODOLÓGICOS, é apresentada a descrição da lógica e dos critérios para escolha de uma pesquisa de caráter exploratório, de natureza qualitativa, que lança mão de um instrumento de pesquisa semiestruturado para realizar entrevistas em profundidade com representantes de micro e pequenas empresas desenvolvedoras, cujos registros foram analisados sob a ótica da análise temática de conteúdo. Este capítulo visou a cumprir com o seguinte objetivo específico: a) Entender a realidade por meio do perfil das empresas e dos entrevistados como ponto de partida da análise.

O Capítulo 5. DISCUSSÃO DOS RESULTADOS visou a cumprir os objetivos específicos b) e c): Compreender distintas visões estratégicas no diz respeito à gestão de marketing levando-se em consideração seu histórico e a situação atual e realizar um diagnóstico das formas de gestão de marketing e seus principais aspectos dentro de seu contexto operacional e mercadológico, respectivamente. O cumprimento da totalidade dos objetivos específicos viabilizou seu fechamento em resposta ao objetivo principal: "Elencar, descrever e qualificar 
grandes desafios que as micro e pequenas empresas desenvolvedoras brasileiras de jogos digitais precisam superar para melhorar sua gestão de marketing", descritos no subitem 5.3.

No Capítulo 6. CONCLUSÕES, LIMITAÇÕES E ESTUDOS FUTUROS, as conclusões são apresentadas, além de serem apontados os limites metodológicos e as possibilidades para o desenvolvimento acadêmico futuro.

Nos APÊNDICES 1 e 2 encontram-se, respectivamente, a versão final do Roteiro de entrevistas e a Carta-base do convite enviado à amostra selecionada. 
Figura 2 - Estrutura do trabalho

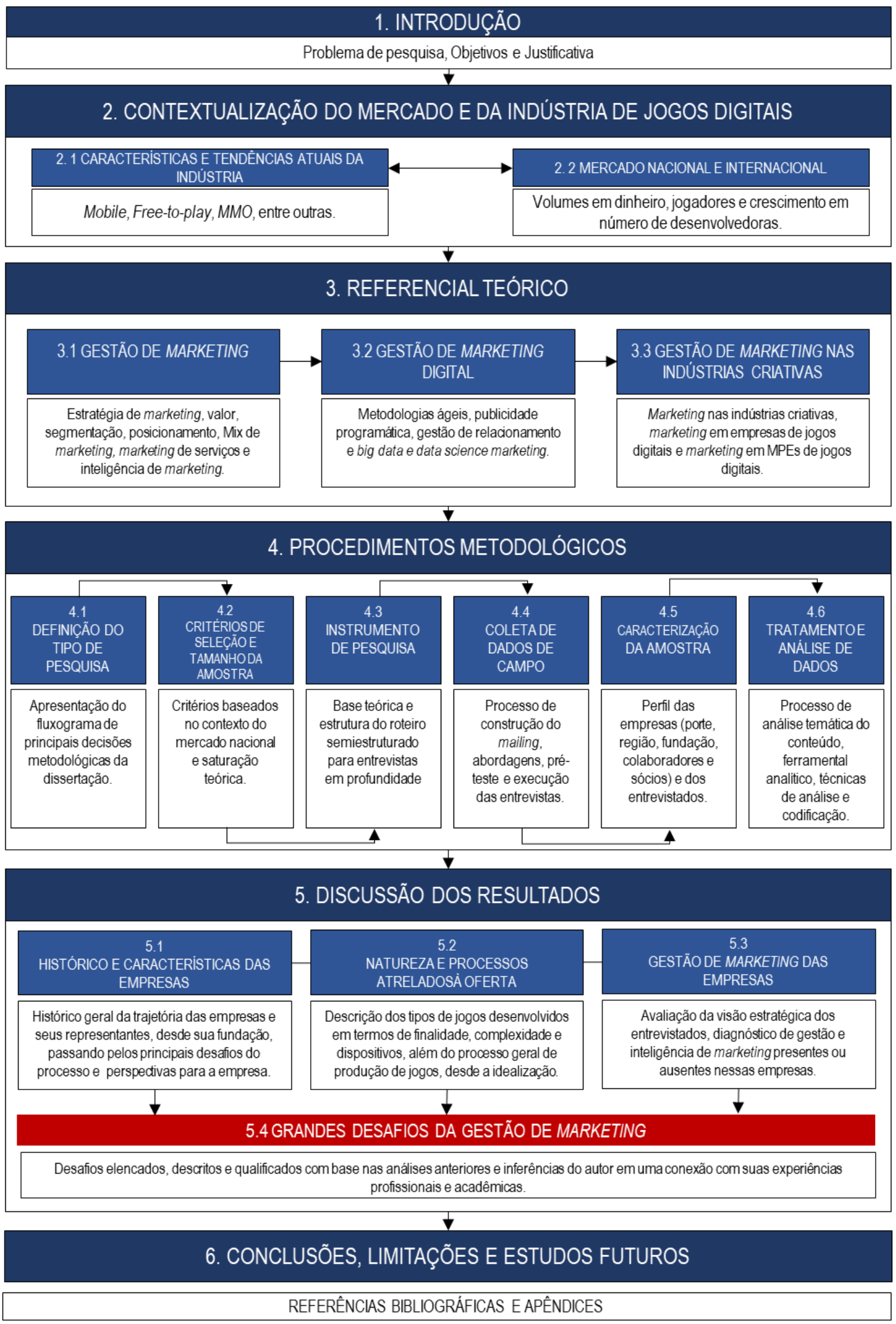

Fonte: Elaborada pelo autor. 


\section{CONTEXTUALIZAÇÃO DO MERCADO E DA INDÚSTRIA DE JOGOS DIGITAIS}

O álbum Thriller, de Michael Jackson, os filmes Vingadores: Ultimato e Avatar e a série de livros Harry Potter geraram volumes expressivos de vendas. No entanto, há uma obra de entretenimento que pode ser considerada a de maior sucesso financeiro de todos os tempos, tendo arrecadado mais de 6 bilhões de dólares, com 90 milhões de cópias vendidas (CHERNEY, 2018). Essa obra quebrou 7 (sete) recordes mundiais registrados no Guinness Book, dentre eles: "propriedade de entretenimento que mais rápido atingiu US\$ 1 bilhão em faturamento" e "produto de entretenimento que gerou o maior faturamento em 24 horas" (LYNCH, 2013). Essa obra é, na realidade, um videogame: o GTA V, jogo de ação em mundo aberto com possibilidades de interação entre múltiplos jogadores simultaneamente conectados online em todo o mundo (ROCKSTAR GAMES, 2020).

Figura 3 - Comparação entre o filme Avatar e o videogame GTA V ${ }^{4}$

\section{Grand Theft Auto V's record run Since it's launch in 2013 Grand Theft Auto V (GTA 5) has sold 90 million units,
putting its total haul for publisher Take-Two Interactive Inc. in the neighborhood
of $\$ 6$ billion, making it the highest grossing media title to date.}

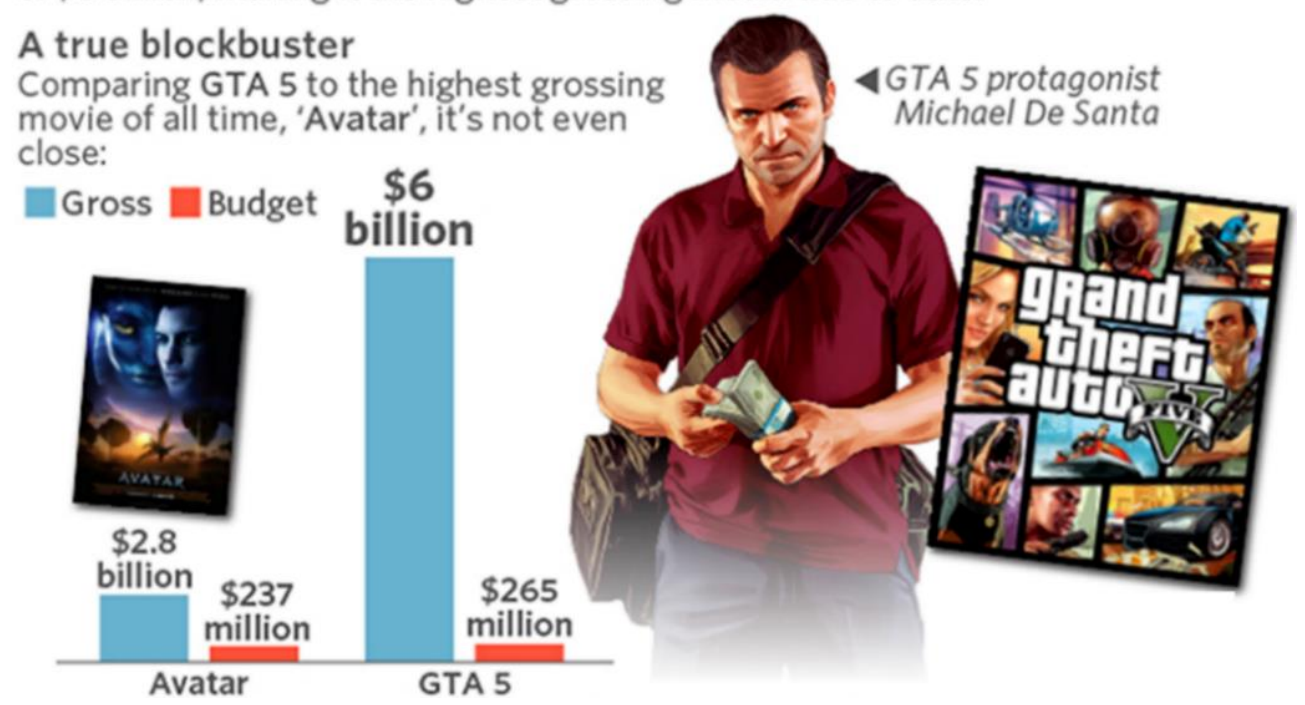

Fonte: Chemey (2018, n.p.).

A Figura 3 apresenta a comparação da receita e dos custos entre o videogame GTA V e o filme Avatar, recordista de bilheteria nos cinemas durante o mesmo período, ilustrando

\footnotetext{
${ }^{4}$ Por uma escolha artística dos criadores do infográfico, o gráfico apresentado está desproporcional, mas os valores apresentados estão corretos. Em azul (gross), apresenta-se a receita bruta e em vermelho (budget), o orçamento (CHEMEY, 2018, n.p., tradução nossa).
} 
grandes diferenças em termos de Retorno sobre o Investimento (Return on investment - $\mathrm{ROI}^{5}$ ) e materializando o impacto que esse produto causou na Indústria do Entretenimento.

Se for utilizada uma medida simples de Retorno sobre o Investimento, o filme Avatar obteve um ROI de 10,8 (US\$2,8 bilhões menos US \$ 237 milhões, sobre US\$ 237 milhões), ou seja, trata-se de um filme que rendeu praticamente 11 vezes o custo de sua produção, o que é um marco histórico. O videogame GTA V, por sua vez, obteve um ROI de 21,6, ou seja, rendeu praticamente 22 vezes o seu custo de produção, muito acima de seu "rival" equivalente na Indústria Cinematográfica.

$\mathrm{Na}$ realidade, é um fato amplamente disseminado que a Indústria de Jogos Digitais superou as Indústrias Musical e Cinematográfica, que, mesmo combinadas, não conseguem atingir os mesmos níveis anuais de faturamento, que chegam a ser 2,5 vezes maiores ${ }^{6}$ (STEWART, 2019).

Apesar das nuances e das definições sobre o início oficial da Era dos Videogames, há que se mencionar a década de 1940 como uma década-chave, com esforços de cientistas da computação debruçando-se sobre a ideia de que computadores poderiam não somente "pensar", mas também “jogar”. Nessa época, surgiram algumas patentes de máquinas computadoras que “desafiavam" seus usuários, evoluindo, na década seguinte, para protótipos como o videogame de tênis de Willy Higinbothan, em 1958, que tinha como aparato gráfico um osciloscópio (NATIONAL MUSEUM OF PLAY, 2020).

Ainda assim, aborda-se a questão de aparatos eletrônicos restritos a círculos acadêmicos e a laboratórios de grandes empresas, com pontuais demonstrações públicas. Pode-se afirmar que a Era Moderna dos Videogames teve início na década de 1970, sob a liderança do Atari, que popularizou os arcades $^{7}$ e os videogames domésticos (ou consoles ${ }^{8}$ ), com novas

\footnotetext{
5 O criador do conceito de ROI foi Donaldson Brown (1885-1965). Maiores informações disponíveis em: https://www.hagley.org/librarynews/father-roi-donaldson-brown. Acesso em: 29 mar. 2021.

${ }^{6}$ Maiores detalhes sobre o faturamento da Indústria de Jogos Digitais estão no subitem 2.2 MERCADO NACIONAL E INTERNACIONAL.

${ }^{7}$ Arcades (ou arcade games) são máquinas de videogames presentes em ambientes comerciais que funcionam à base de moedas proprietárias (os ambientes são chamados de fliperamas ou salões de jogos). Maiores informações disponíveis em: https://educalingo.com/pt/dic-en/arcade-game. Acesso em: 12 dez. 2020.

${ }^{8}$ No Brasil, é muito comum referir-se a consoles de videogame simplesmente como videogames. Neste trabalho, referimo-nos aos videogames como os componentes abstratos, a programação do jogo em si e os consoles como os aparelhos domésticos (um tipo possível de plataforma, além de celulares e de computadores, por exemplo) que, quando conectados à TV, viabilizam o acesso ao mundo virtual de um ou mais videogames. Maiores informações disponíveis em: https://educalingo.com/pt/dic-pt/videogame. Acesso em: 12 dez. 2020.
} 
possibilidades para a época, como a troca de jogos por meio de cartuchos $^{9}$ (NATIONAL MUSEUM OF PLAY, 2020).

No Brasil, a primeira grande onda popular desses dispositivos foi verificada na década de 1980, especificamente com o lançamento do Atari 2600, com 500 possibilidades de jogos em cartuchos. Lançado nos EUA, em 1977, ele chegou ao mercado brasileiro somente 6 anos mais tarde, por intermédio da Polivox, uma subsidiária da Gradiente (VICTOR, 2018).

Desde então, a Indústria de Jogos Digitais vem evoluindo com intervalos cada vez menores entre os lançamentos nacionais e os internacionais, superando momentos de crise e enfrentando diversos desafios ao longo dos anos.

\subsection{CARACTERÍSTICAS E TENDÊNCIAS ATUAIS DA INDÚSTRIA}

A seguir, será apresentado o resumo sobre as principais tendências atuais da Indústria de Jogos Digitais, elaborado com base nas informações extraídas e consolidadas de sites especializados, tais como: Museum of Play (2020), Jornada Geek (2018), Game Designing.org (2020) e outras fontes complementares mencionadas.

\subsubsection{Jogos Mobile}

Há algumas décadas, a preocupação com o conforto e com a mobilidade vem sendo uma constante entre os desenvolvedores de videogames. A criação dos consoles domésticos, mencionada anteriormente, é um bom exemplo: os videogames passaram a fazer parte dos lares, criando um vínculo mais íntimo e mais prático, sem necessidade de grandes deslocamentos para estabelecimentos comerciais.

Paralelamente à onda de videogames caseiros, a Nintendo entrou no mercado de jogos portáteis (aparelhos que, em geral, cabem na palma da mão), caminho aberto anteriormente pela Mattel, em 1976, que assumiu sua liderança a partir de 1980, com sucessos de venda como o Game \& Watch, passando pelas linhas Game Boy e Game Boy Color até os dias atuais com os aparelhos Nintendo DS e Nintendo Switch.

\footnotetext{
${ }^{9}$ Cartuchos ou "fitas" são os nomes dados a peças físicas que contêm a programação do jogo. São inseridos nos consoles para transmitir os dados do videogame à tela do jogador. Maiores informações disponíveis em: https://gizmodo.uol.com.br/hardware-cartuchos-videogame/. Acesso em: 12 dez. 2020.
} 
Esses lançamentos permitiram que as pessoas jogassem em praticamente quaisquer lugares: em casa, na rua, nos deslocamentos entre a escola e o trabalho, entre outros. Portanto, a mobilidade sempre foi uma questão presente e crucial na indústria, potencializada a níveis até então não verificados com os smartphones (em português, telefones celulares inteligentes).

Além da mobilidade física, proporcionada por aparelhos dedicados, os smartphones proporcionam uma mobilidade virtual de proporções até então inexistentes. Eles possibilitam: fazer downloads instantâneos dos jogos desejados, dentre milhares de opções disponíveis em lojas virtuais, em substituição aos minidiscos e aos cartuchos do passado; jogar com pessoas de quaisquer partes do mundo a partir de uma conexão com a Internet; contar com atualizações dos jogos, sem necessidade de compra de novas versões; e também realizar transações financeiras para compra de jogos e itens, conectando meios de pagamento e aplicativos já instalados no próprio aparelho, que se tornou um verdadeiro centro de diversão, comunicação, trabalho e gerenciamento da vida cotidiana, além de outras funções.

No ecossistema mobile atual também estão inclusos os aparelhos portáteis dedicados a jogos como os da Nintendo e os tablets, que complementam e disputam certos nichos do mercado.

\subsubsection{Free-to-Play}

Historicamente, o mercado de jogos apoiou-se em 2 (dois) grandes modelos de geração de receita: pagamento pela experiência por determinado tempo (arcades ou pagamento por hora de utilização de consoles) e aquisição de mídia física do jogo (cartuchos, CDs, DVDs, BlueRays e similares), tornando-se uma propriedade do adquirente e podendo ser consumido a qualquer momento pelo jogador.

O modelo de mídia física deu espaço à pirataria (venda de cópias ilegais de jogos) mesmo problema enfrentado pelas Indústrias Musical e Cinematográfica ${ }^{10}$, um duro golpe para as empresas do setor, especialmente no final da década de 1990 e no início dos anos 2000.

Nos últimos anos, especificamente a partir de 2014, uma nova forma de geração de receita passou a ganhar destaque e a dominar a indústria, sobretudo entre os mobile games: o modelo "free-to-play". Esse modelo funciona da seguinte forma: o jogador pode "baixar" e

\footnotetext{
${ }^{10}$ Antes da popularização do consumo "digitalizado" de música e filmes, a indústria cinematográfica e musical vinham acumulando grandes prejuízos por conta de cópias ilegais em todo o mundo. No Brasil, em 2007, representantes dessas indústrias uniram-se para adotar medidas de vendas de cópias ilegais de CDs e DVDs. Maiores informações disponíveis em: https://culturaemercado.com.br/industria-de-cinema-e-musica-contra-apirataria/. Acesso em: 20 mar. 2021.
} 
jogar sem ter que pagar, geralmente pelo tempo que desejar, e evoluir sem nenhum comprometimento financeiro prévio. Mas, o mesmo jogador pode potencializar suas chances de sucesso ou de destaque entre a comunidade do jogo, a partir da compra de itens especiais, que se materializam em forma de armas, acessórios ou mais rodadas, que oferecem mais vantagens sobre os demais jogadores, e as chamadas skins, que são apetrechos geralmente estéticos com alguma função social (são mecanismos de status por sua raridade ou exclusividade).

Esses itens especiais são adquiridos por meio de micro transações "dentro" do próprio jogo e geram montantes consideráveis de receita para empresas como a SuperCell, que já chegou a faturar mais de 1 milhão de dólares por dia em micro transações realizadas no jogo Clash of Clans $^{11}$ (TAKAHASHI, 2017).

\subsubsection{Massive Multiplayer Online - MMO}

Antes impensável pela incipiência e pelo pouco poder de transmissão de dados da Internet, atualmente, temos possibilidade de jogar com qualquer pessoa, em qualquer parte do mundo, em tempo real, sem grandes dificuldades. Foi a partir do rompimento dessa barreira tecnológica que se popularizaram os jogos com multijogadores online em massa (Massive Multiplayer Online ou MMOs, sigla em inglês). Em essência, são jogos que permitem a interação online de dezenas ou centenas de jogadores simultaneamente, em uma mesma sessão (CANALTECH, 2012). Jogos famosos desse segmento como World of Warcraft $^{12}$ (WoW) e League of Legends ${ }^{13}(\mathrm{LoL})$ registram aproximadamente 30 milhões de jogadores ativos por dia e vendem US\$ 9 bilhões em micro transações, desde 2016 (RAGE ZONE, 2020).

Um gênero de MMO cada vez mais popular é o Battle Royale, um estilo de jogo em que a premissa básica é "ser o último jogador a ficar de pé". São jogos em que dezenas e até centenas de players são colocados em um grande ambiente virtual, geralmente com o tamanho em escala de uma grande cidade, e precisam lutar para sobreviver. Atualmente, um dos mais populares do

\footnotetext{
${ }^{11}$ Clash of Clans é um jogo do gênero Estratégia para plataformas mobile lançado em 2012 pela empresa Supercell. Maiores informações disponíveis em: https://supercell.com/en/games/clashofclans/. Acesso em: 20 mar. 2021.

${ }^{12}$ World of Warcraft (WoW) é um Role-Playing Game (RPG) lançado em 1994 para PC e evoluído para outras versões até sua forma MMO (Massive Multiplayer Online), em 2004. Maiores informações disponíveis em: https://worldofwarcraft.com/en-us/story/timeline. Acesso em: 20 mar. 2021.

${ }^{13}$ League of Legends (LOL) é um Massive Multiplayer Online Battle Arena lançado em 2009 pela Riot Games. Maiores informações disponíveis em: https://www.riotgames.com/pt-br/quem-somos/valores. Acesso em: 19 mar. 2021.
} 
gênero é o Call of Duty: Warzone ${ }^{14}$, que atingiu 75 milhões de jogadores ativos, em agosto de 2020 (GOUGH, 2020).

\subsubsection{Ampliação do Público Gamer}

Videogames já foram associados à ideia de que seriam feitos para crianças e adolescentes mais afastados de círculos sociais comuns, os chamados nerds, significação que persistiu ao longo dos anos, sempre com certa resistência por parte de pessoas de mais idade que não tiveram tanto contato com jogos desse tipo na infância, por exemplo.

No entanto, há alguns anos, tem-se observado uma maior inclusão de outros segmentos de jogadores. Alguns fatos contribuíram para esse avanço: o lançamento do Nintendo Wii, em 2007, que representou um rompimento com a tradição de consoles que prometiam melhor desempenho, superando-os em vendas em função de seus jogos feitos especialmente para jogadores mais casuais - 25 milhões de unidades vendidas, em 2009 (HOLST, 2020); o crescimento em vendas dos smartphones, que aproximaram o mundo dos jogos às pessoas com pouco envolvimento e que, provavelmente, não gastariam dinheiro com consoles ou com outros aparelhos dedicados; e, por fim, a própria saturação do público mais fiel aos jogos digitais, forçando desenvolvedores e empresas do ramo a procurarem novos segmentos e novas demandas.

\subsubsection{Realidades Virtual e Aumentada}

A busca por maior imersão e realismo nos jogos faz parte de uma fase mais moderna da indústria, com aparelhos cada vez mais capazes de transportar os jogadores para mundos virtuais, como o Oculus Rift ${ }^{15}$, precursor de uma série de esforços posteriores para criar ambientes virtuais que exploram com maior intensidade os sentidos de seus jogadores.

Em termos de realidade aumentada, podemos citar o Pokémon $G o^{16}$, jogo mobile que permite a "inserção" de elementos do jogo no mundo real, a partir da câmera do celular,

\footnotetext{
${ }^{14}$ Call of Duty: Warzone é um jogo da franquia Call of Duty que traz a mecânica de "tiro em primeira pessoa" para o gênero Battle Royale, lançado em 2020 pela Actvision. Maiores informações disponíveis em: https://www.callofduty.com/warzone. Acesso em: 19 mar. 2021.

${ }^{15} \mathrm{O}$ Oculus Rift é um equipamento que serve para imergir o jogador em uma realidade virtual acessada pelos olhos. Fabricada pela Oculus VR, a empresa foi comprada pelo Facebook em 2014 que lançou o produto em 2016. Maiores informações disponíveis em: https://www.kickstarter.com/projects/1523379957/oculus-rift-step-into-thegame. Acesso em: 21 mar. 2021.

${ }^{16}$ Pokémon Go é um jogo de realidade aumentada para dispositivos móveis lançado pela empresa Niantic, em 2016. Maiores informações disponíveis em: https://pokemongolive.com/en/. Acesso em: 11 nov. 2020.
} 
conforme ilustra a Figura 4. O Pokémon Go acumulou aproximadamente 1 bilhão de downloads, até março de 2019, e 3 bilhões de dólares em receita, até outubro de 2019 (IQBAL, 2020).

Figura 4 - Função de realidade aumentada do jogo Pokémon Go

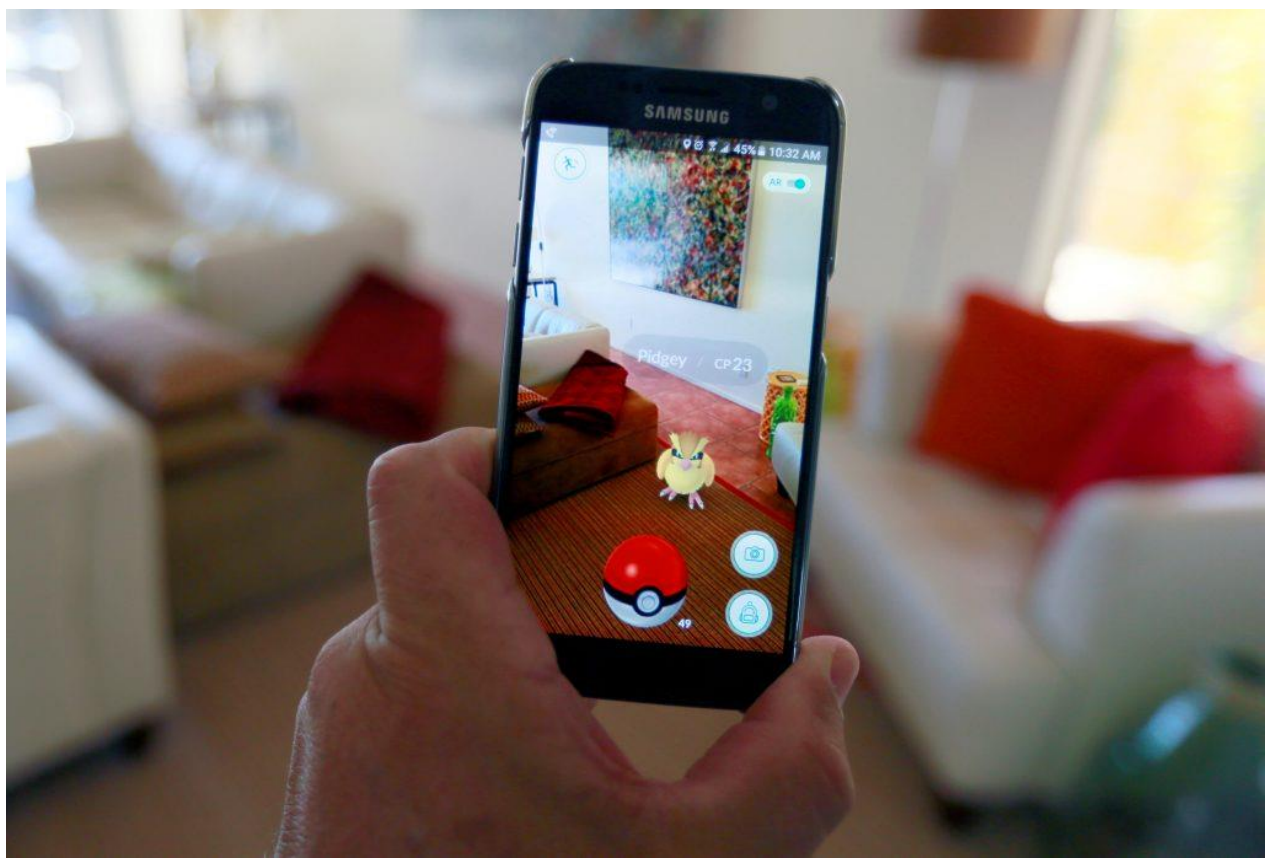

Fonte: PBS.org (2016, n.p.).

\subsubsection{Streaming e Multiplataforma}

Assim como nas Indústrias Musical e Cinematográfica, a utilização de hardware $^{17}$ pode ser mais variada, flexível e até reduzida a aparelhos cada vez menores. O Google Stadia, por exemplo, foi um considerável esforço nesse sentido com a criação de uma plataforma online similar à Netflix, na qual é possível jogar via tecnologia streaming ${ }^{18}$, que processa os elementos gráficos do jogo em computadores a milhares de quilômetros de distância, longe do alcance do usuário, o qual precisa somente de um celular, de um computador ou mesmo da televisão para poder jogar.

Apesar do insucesso inicial desse empreendimento por conta de severas limitações tecnológicas dos tempos atuais (CASWELL, 2020), é razoável acreditar que no futuro os jogos

\footnotetext{
${ }^{17}$ Hardwares são elementos físicos que compõem a experiência do jogo, envolvendo tudo o que pode ser tocado como os consoles, celulares, computadores ou aparelhos periféricos (como controles e TVs). Maiores informações disponíveis em: https://techterms.com/definition/hardware. Acesso em: 10 mar. 2021.

${ }^{18}$ A tecnologia streaming faz com que o Google Stadia, assim como o Netflix, sejam capazes de transmitir o conteúdo a distância, sem a necessidade de utilização de um dispositivo dedicado de processamento e memória (ex.: Aparelhos e DVDs de filmes ou de jogos). Maiores informações disponíveis em: https://stadia.google.com/. Acesso em: 10 mar. 2021.
} 
poderão ser acessados com a menor quantidade possível de aparelhos. Além disso, já se observa uma quantidade considerável de jogos que podem ser acessados por múltiplos aparelhos, os chamados multiplataformas, conectando comunidades até então separadas: a dos computadores pessoais (PCs), a dos consoles e a dos smartphones (BOBOLOGY, 2020).

\subsubsection{E-sports e Comunidades Online}

Os videogames não representam um fim em si mesmos: há todo um ecossistema formado por criadores de conteúdo, produtos licenciados e campeonatos promovidos pelas próprias desenvolvedoras ou por organizações independentes, além de toda infraestrutura energética e tecnológica necessária para sua manutenção.

Entre os distintos tipos de eventos, os que envolvem competição a nível profissional compõem o que se convencionou chamar $e$-sports, que representam a prática de competição entre players pela organização de campeonatos e um sistema similar ao realizado em esportes como o futebol, por exemplo.

Isso é fruto de uma organização eficiente de competição e, ao mesmo tempo, da manutenção de comunidades de jogadores que organizam encontros e grupos (geralmente virtuais) para trocarem experiências e conhecimentos a respeito de seus jogos preferidos. $\mathrm{O}$ relatório da Newzoo (2020a) estima uma audiência aproximada de $e$-sports de 495 milhões de pessoas em 2020, seguindo uma histórica taxa média de crescimento anual de 11,7\%.

\subsubsection{Exploração das Emoções e Incremento da Experiência}

A Flow Theory (ou Teoria do Fluxo) refere-se a um estado mental que propicia um sentimento de apreciação durante uma atividade, no qual se estabelece um balanço entre as habilidades do indivíduo e os desafios impostos pela atividade em si para a obtenção de uma recompensa intrínseca. O 'fluxo' também pode incluir a emergência de uma sensação de ‘domínio da situação' e experimentação de distorções de tempo (CSIKSZENTMIHALYI; CSIKSZENTMIHALYI, 1992).

É um nível profundo de concentração e engajamento em uma atividade que bons videogames conseguem propiciar, indispensável a qualquer projeto do tipo. Com o acirramento da concorrência, a emergência de novos tipos de jogadores e as novas tecnologias, os desenvolvedores são confrontados diariamente ante ao desafio de criarem jogos suficientemente interessantes para engajarem suas audiências. 
Esse processo passa pelo entendimento mais profundo dos desejos, emoções e necessidades dos jogadores, além de modelos preditivos baseados em dados de navegação no ambiente virtual para guiar alterações substanciais na experiência proporcionada.

\subsection{MERCADO NACIONAL E INTERNACIONAL}

O mercado mundial de videogames movimentou, em 2020, o montante aproximado de 159,3 bilhões de dólares ${ }^{19}$ e deve atingir 200 bilhões até o fim de 2023. É um mercado que cresce a uma taxa média anual de 9,3\%. Aproximadamente $74 \%$ desse valor estão concentrados na América do Norte e na Ásia (somada à região do Pacífico), sendo os Estados Unidos e a China os países protagonistas (NEWZOO, 2020b) (Figura 5).

Figura 5 - Mercado global de videogames por região

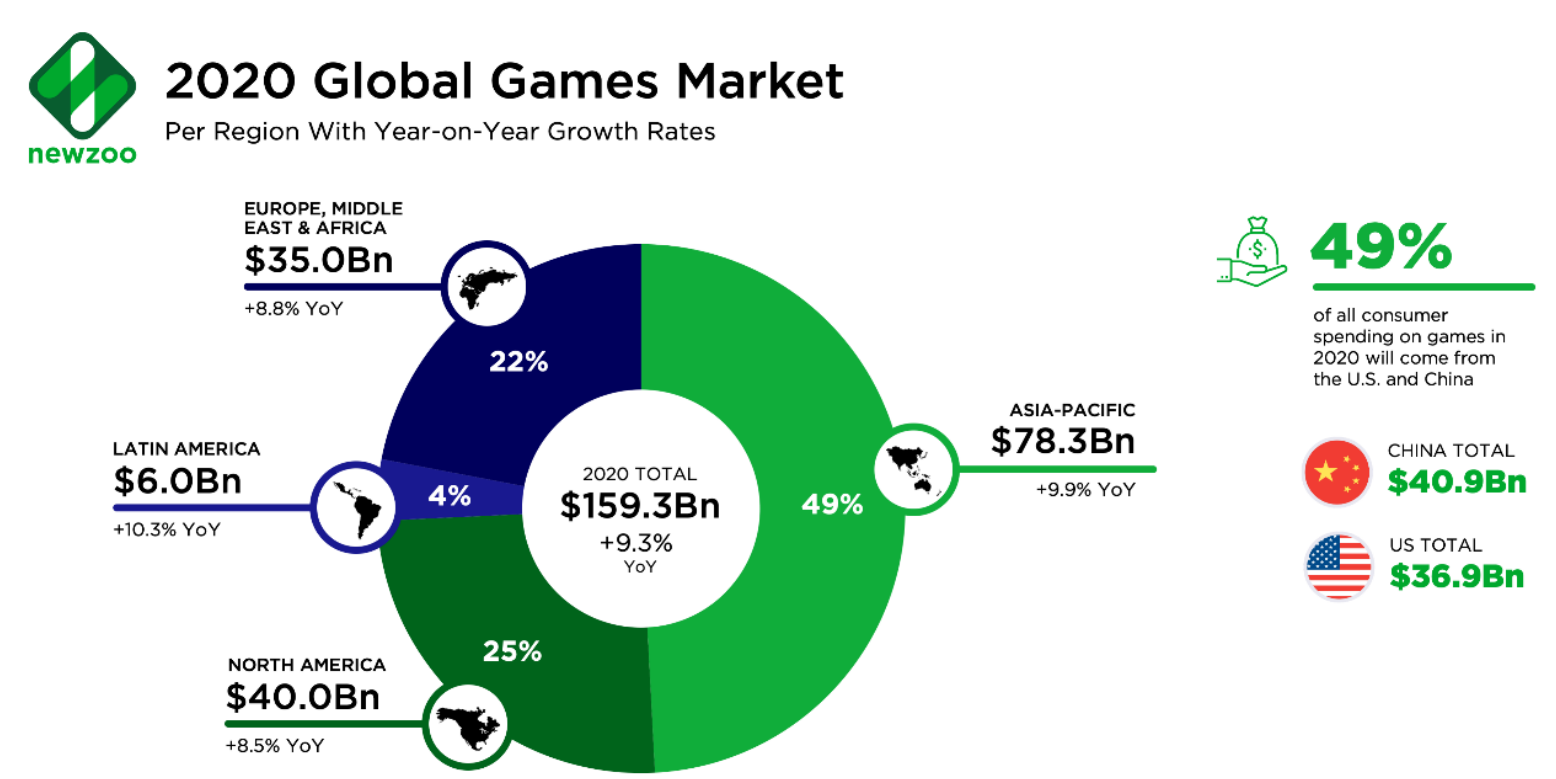

Fonte: Newzoo (2020b, n.p.).

De acordo com a Newzoo (2020b), o mercado de games na América Latina movimenta US\$ 6 bilhões anuais, detendo 4\% do mercado total (Figura 5). O Brasil movimentou, em 2019, US\$ 1,6 bilhões de dólares ${ }^{20}$, representando aproximadamente 1 terço do mercado latino-

\footnotetext{
${ }^{19}$ Números estimados pelo relatório Newzoo. Até o momento da finalização da presente dissertação, os dados consolidados referentes ao mercado mundial de videogames em 2020 ainda não haviam sido divulgados.

${ }^{20}$ Até o momento da finalização da presente dissertação, os dados atualizados referentes à movimentação do mercado de games no Brasil em 2020 ainda não haviam sido publicados pela Newzoo. Não foram colocadas estimativas para 2020, pois é razoável supor que os números oficiais a serem publicados, em 2021, ainda venham acompanhados dos efeitos da pandemia do Coronavírus.
} 
americano e $1 \%$ do mercado mundial, possuindo $3 \%$ do total de jogadores (76 milhões de indivíduos, aproximadamente). Como há grande concentração de faturamento em determinados países, o Brasil acaba sendo o $13^{\circ}$ maior mercado mundial e o maior da América Latina (LARGHI, 2019).

O número de jogadores também vem crescendo a taxas anuais consideráveis $(6,4 \%$ em média), somando, atualmente, cerca de 2,7 bilhões de pessoas, o que representa $34 \%$ da população mundial (NEWZOO, 2020b; WORLD METER, 2020) (Figura 6), ou seja, um terço da população mundial possui algum tipo de contato com jogos de videogame.

Figura 6 - Volume global de jogadores por região

\section{Global Gamers}

Per Region With Year-on-Year Growth Rates
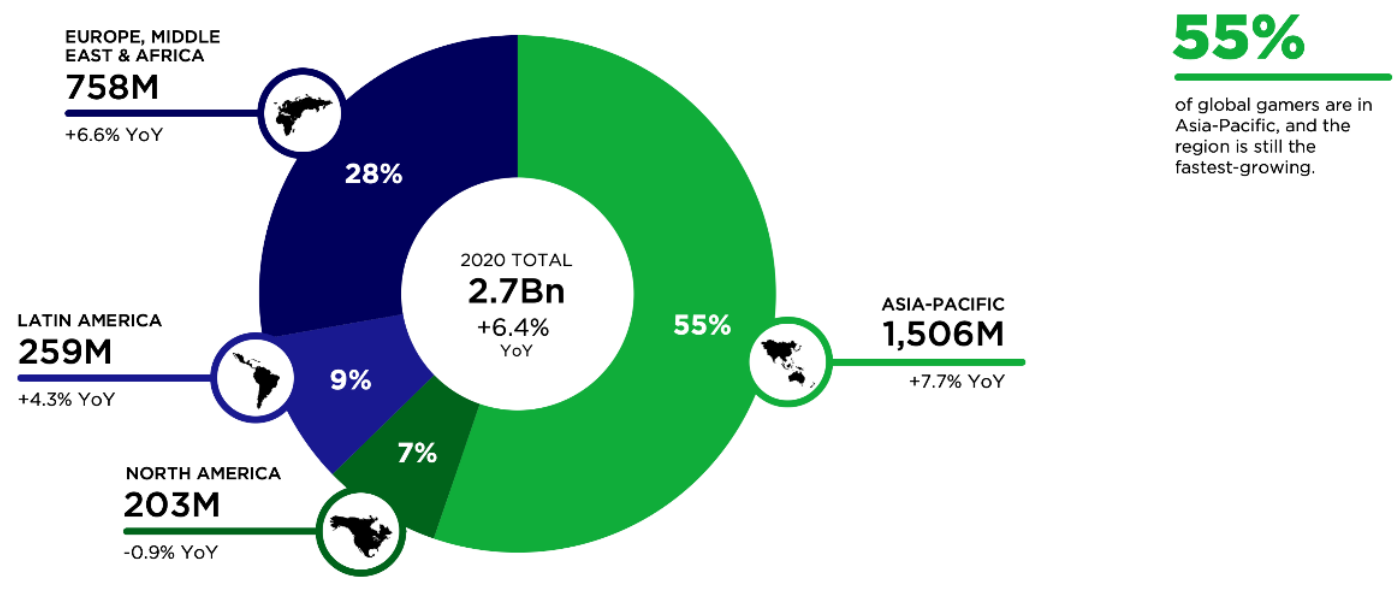

Fonte: Newzoo (2020b, n.p.).

De acordo com o Segundo Censo da Indústria Brasileira de Jogos Digitais, no início de 2018, havia no Brasil 375 empresas desenvolvedoras de jogos digitais (MINC, 2018). Como vem apresentando um crescimento médio anual de $16,1 \%$, estima-se, no início de $2020^{21}$, a existência de aproximadamente 505 desenvolvedoras. Trata-se de um ritmo de crescimento acelerado, especialmente quando comparado com o setor de software de forma geral (crescimento 2,5 vezes maior) (MINC, 2018).

Geralmente, são empresas que possuem no máximo 15 colaboradores (cerca de $85 \%$ delas), com 2 a 5 sócios. Trata-se de um universo predominantemente masculino (79,3\% são

\footnotetext{
${ }^{21}$ A taxa de crescimento acumulada divulgada pelo Censo da Indústria Brasileira de Jogos Digitais entre 2014 e 2018 foi de $182 \%$. Pela extração da raiz quarta, chegou-se à taxa anual de 16,1\% que, aplicada em 2018 e 2019 , resultou em 505 desenvolvedoras estimadas. A estimativa foi realizada até o início de 2020 por coincidir com o início dos procedimentos de campo do estudo.
} 
homens), com proporções ainda maiores em áreas como programação e gestão de projetos (89\%) (MINC, 2018).

Os jogos produzidos dividem-se em duas categorias básicas: os de entretenimento (49\%) e os serious games (ou "jogos sérios”) (51\%). No mercado brasileiro, por questão de sobrevivência, as empresas tendem a ocupar boa parte de seus recursos de desenvolvimento com jogos encomendados por terceiros, por trazerem um retorno sobre o investimento mais rápido do que os jogos próprios.

Os serious games são, em sua maioria, encomendados por terceiros (76\%), com o propósito de educar, treinar colaboradores de empresas, auxiliar em tratamentos de saúde, simular atividades cotidianas como dirigir, entre outras. Quase metade dos jogos de entretenimento (45\%), por sua vez, também é feita sob encomenda, para terceiros, o que inclui jogos feitos para promover marcas de empresas (os chamados Advergames - ou "jogos de publicidade") (MINC, 2018).

A maioria dos jogos desenvolvidos é para dispositivos móveis (43\%) assim como nos mercados mais desenvolvidos, seguidos por jogos para computador (24\%) e web - jogos que podem ser acessados diretamente em navegadores da Internet (16\%). Apenas 5\% são jogos feitos para consoles (MINC, 2018), distantes da proporção de receita mundial de 25\% (WIJMAN, 2018) aferida no mesmo ano de realização do Segundo Censo da Indústria Brasileira de Jogos Digitais.

Esse é um reflexo da incipiência e da falta de recursos financeiros da indústria nacional, pois o custo de jogos para dispositivos móveis pode variar entre US\$ 3,5 mil e US\$ 150 mil, enquanto os jogos para consoles, por serem mais complexos e proporcionarem experiências de maior envolvimento, facilmente ultrapassam a marca de 1 milhão de dólares em custos de produção (GAME ACE, 2017). Na lista dos 25 videogames mais jogados no Brasil, em setembro de 2020, em sua maioria disponíveis para consoles, todos são internacionais, nenhum deles é brasileiro (NEWZOO, 2020c).

O faturamento anual das desenvolvedoras de jogos digitais brasileiras, em 2017, mostra o quão distante elas se encontram da capacidade de desenvolvimento de jogos de maior complexidade sob o ponto de vista financeiro. 97\% são micro e pequenas empresas (MPEs), com faturamento inferior a $\mathrm{R} \$ 2,4$ milhões. Destas, 61,7\% não ultrapassam $\mathrm{R} \$ 81$ mil de faturamento e menos de 5\% faturam mais de R\$ 1 milhão (MINC, 2018). Há raríssimas 
exceções como a WildLife, empresa brasileira que, em 2019, passou a fazer parte do grupo de 'unicórnios'22 nacionais - avaliada em mais de 1 bilhão de dólares (SAMOR, 2019).

Assim, o mercado brasileiro é composto, em sua maioria, por micro e pequenas empresas, com pouca disponibilidade de mão de obra, grande dependência de encomendas de terceiros e foco na produção de jogos menos complexos, por necessitarem de baixos investimentos e, em sua maioria, distribuídos via dispositivos móveis e computadores. O Capítulo 3 a seguir visa a trazer o referencial teórico capaz de abarcar o universo da gestão de marketing com base nessas especificidades.

\footnotetext{
${ }^{22}$ Unicórnio (Unicorn, em inglês) é um termo utilizado para descrever uma startup (empresa nova com modelo de negócio escalável, geralmente com base em novas tecnologias) que supera a marca de US\$ 1 bilhão em valor de mercado. Maiores informações disponíveis em: https://www.investopedia.com/terms/u/unicorn.asp . Acesso em: 11 nov. 2020.
} 


\section{REFERENCIAL TEÓRICO}

A Revisão da Literatura utilizada para compor o referencial teórico da presente dissertação seguiu os preceitos de Moreira (2004): propósito, abrangência, função e abordagem.

No que tange ao propósito, foi realizada uma revisão de base, tendo como núcleo uma pesquisa empírica a ser beneficiada com aprendizados e conexões com outros estudos já realizados. Essa abordagem difere das revisões analíticas, que teriam um fim em si mesmas, geralmente com abordagens sistematizadas para fornecerem um panorama geral de desenvolvimento de determinada área.

A respeito da abrangência, optou-se pela forma temática, que extraiu os principais temas que cobrem o escopo do presente trabalho, sem deixar de admitir a dependência da visão do autor e da evolução da revisão bibliográfica em si, que foi construindo a cadeia de temas-chave envolvidos na resolução do problema e no cumprimento dos objetivos propostos. Não se trata, portanto, de uma abordagem temporal, ainda que boa parte dos conceitos tratados esteja contida em trabalhos publicados entre os séculos XX e XXI e, às vezes, a narrativa contemple algum tipo de linha do tempo para facilitar a compreensão.

Quanto à função da revisão da literatura, trata-se de atualização, uma vez que se buscou suportar a pesquisa proposta com entendimentos mais recentes sobre os conceitos abordados. A função histórica, como possibilidade alternativa, encontra suporte na função principal, em alguns casos, como a própria definição de marketing, um dos principais conceitos-chave tratados.

Por fim, a abordagem seguiu a linha bibliográfica, pois procurou primordialmente elencar conceitos já consolidados, menos passíveis de problematizações e desenvolvimentos críticos que fossem além do escopo proposto. Essa opção não invalidou e nem suprimiu a visão e a opinião do autor, mas procurou criar um saudável distanciamento entre experiências pessoais e fundamentos científicos já estabelecidos.

A Figura 7, a seguir, apresenta resumidamente a inter-relação entre os temas que serviram de base bibliográfica e como ponto de partida da metodologia de pesquisa e das análises realizadas em uma lógica de afunilamento em espiral, partindo dos conceitos mais abrangentes para os mais específicos. 
Figura 7 - Processo de estruturação do referencial teórico

\section{REFERENCIAL TEÓRICO}

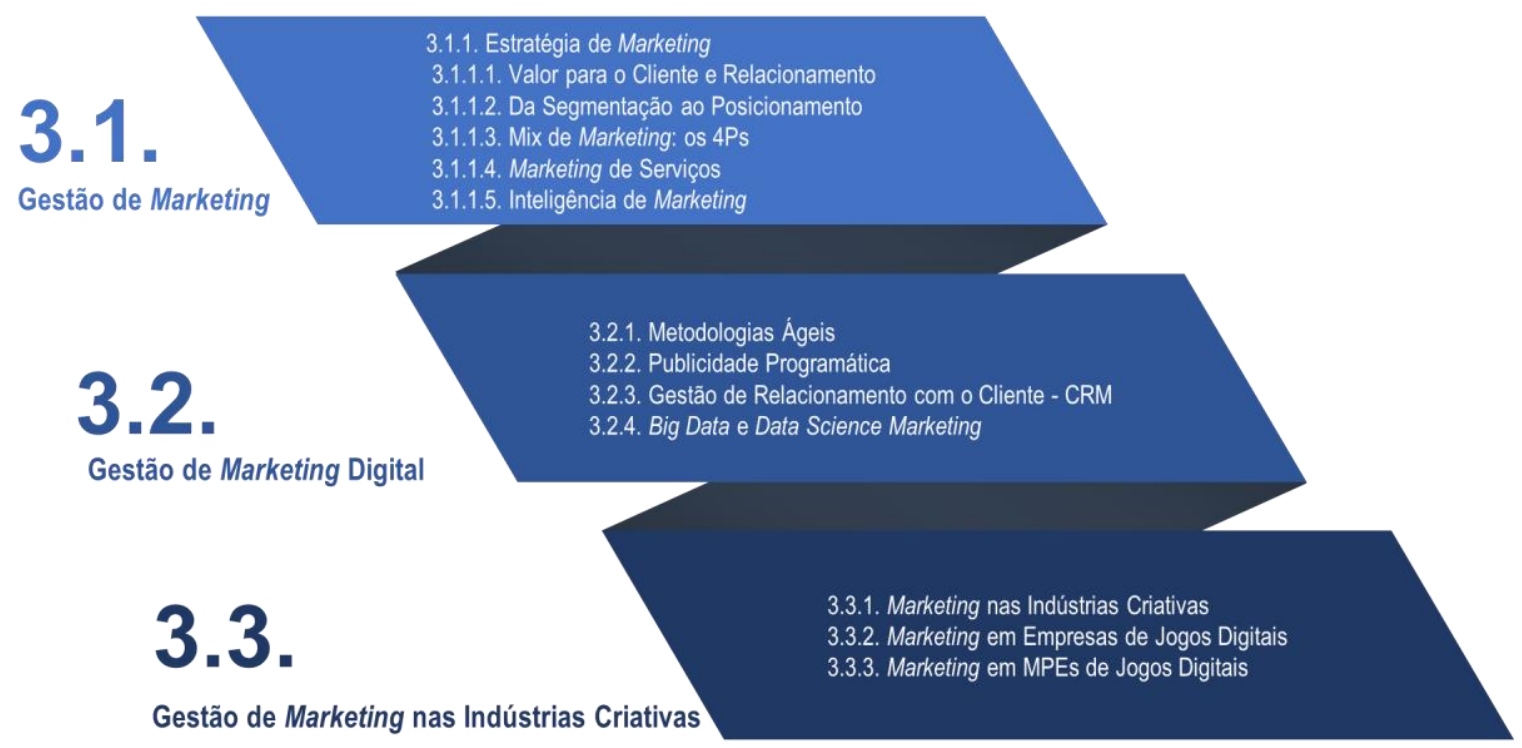

Fonte: Elaborada pelo autor.

A lógica proposta subdivide os fundamentos em 3 principais blocos que orbitam a gestão empresarial no contexto estudado, iniciando com os conceitos-chave de Gestão de Marketing, passando por aspectos atuais marcantes na Gestão de Marketing Digital e, por fim, tratando especificamente da Gestão de Marketing nas micro e pequenas empresas de jogos digitais, que são parte do ecossistema das Indústrias Criativas.

Esses blocos constituem esse continuum de conhecimento que se inter-relacionam e pavimentam o caminho para a investigação proposta pelo presente trabalho.

\subsection{GESTÃO DE MARKETING}

Apesar de relações de troca existirem há milhares de anos como fator crucial de desenvolvimento da vida em sociedade e até mesmo como objeto de discussão filosófica na Grécia antiga (SHAW; JONES, 2005), marketing, palavra do idioma inglês pode ter se originado do substantivo em latim mercatus, designando o local para compra e venda de objetos, ou mesmo dos verbos mercari/mercare traduzidos para o português como "negociar" ou "praticar compra e venda". Marketing pode ser sinônimo de "comercialização" - no caso de práticas empresariais, ou de "mercadologia" - sob uma perspectiva acadêmica. No entanto, apesar de existirem termos equivalentes na língua portuguesa, mesmo assim, o termo em inglês 
é mais comumente utilizado (DICIONÁRIO ETIMOLÓGICO, 2020; DICIONÁRIO ONLINE DE PORTUGÊS, 2020).

Marketing inicia-se como um ramo da ciência e passa a ser considerado pela Academia como disciplina somente em meados do século XX (SHAW; JONES, 2005). Registros históricos do início do século XX reforçam a ideia de que a necessidade de estudar e de compreender melhor os componentes e as atividades de marketing emergiu de fatores como da administração científica de Taylor, em 1903, que contribuiu com o aumento da eficiência da produção em massa e caminhou paralelamente às linhas de produção fordistas em resposta a um aumento da demanda em centros urbanos, derivados de um êxodo rural em um novo tipo de organização social, principalmente nos Estados Unidos (SHAW; JONES, 2005).

Desse contexto surge a necessidade de entender mais profundamente os processos e os componentes envolvidos na distribuição de produtos para o consumo de massa, uma vez que existem desencontros de preço, qualidade, custo e valor agregado às mercadorias entre empresas e consumidores. As contribuições dos estudos de economia comportamental, a partir da metade do século XX, foram cruciais para a geração de modelos descritivos e preditivos a respeito do comportamento dos indivíduos, mas insuficientes por presumirem uma racionalidade muitas vezes inexistente no ato de consumir, que creditava ao consumidor a necessidade natural de maximizar a utilidade do produto, equilibrar seus prós e contras e tornar o ato de consumo o mais eficiente possível (CAMERER; LOEWENSTEIN, 2002).

Marketing nasceu, em um primeiro momento, como uma subdisciplina da Economia e, ao longo do tempo, passou a incorporar conhecimentos de outros campos de estudo, como os da Psicologia (ou o "fator humano"), da Sociologia e da Administração para solucionar problemas mercadológicos e científicos sob novas perspectivas, superando limitações teóricas e práticas anteriormente observadas (SHAW; JONES, 2005).

Ao longo dos estudos de marketing foram surgindo uma série de linhas de pesquisa e escolas de pensamento que abriram caminhos para sua solidificação como disciplina independente e seus respectivos questionamentos, como Marketing Functions - quais são as principais funções de marketing?; Marketing Commodities - quais são as principais características e papéis dos produtos comercializados?; Marketing Institutions - quais são e como se relacionam as principais organizações entre a produção e a entrega de bens ao consumidor final?; Marketing Exchange - quem, o quê, quando, onde e com qual propósito as trocas ocorrem?; ou Marketing Systems/Macro-marketing - como a sociedade afeta os sistemas de marketing e vice-versa? (SHAW; JONES, 2005), que não foram abordadas em profundidade nesta dissertação por fugirem ao escopo e aos objetivos propostos. 
Portanto, as demais seções que compreendem a definição, os processos e as aplicações de marketing, a metodologia de pesquisa e a interpretação de resultados restringem-se às mais modernas e populares formas de pensamento de marketing representadas, por um lado, pela escola de Administração de Marketing (Marketing Management) - na perspectiva de uma empresa ou empreendedor e, por outro, pela escola de Comportamento do Consumidor (Consumer Behavior) - sob o ponto de vista de pessoas interessadas em determinada oferta, que, no nosso contexto, representam os jogadores de jogos digitais (SHAW; JONES, 2005).

A primeira perspectiva é a predominante, dado o objeto de estudo (empresas de jogos digitais que precisam fazer 'Gestão de Marketing', utilizada nesse trabalho como sinônimo de 'Administração de Marketing') e a segunda, funciona como apoio à interpretação dos pontos de vista e das opiniões dos empreendedores acerca de atividades que buscam entender e se relacionar melhor com seus públicos consumidores.

A Escola de Administração de Marketing procura responder à seguinte questão: como as organizações devem gerir seus recursos para entregar ao mercado seus produtos e serviços? (SHAW; JONES, 2005), ou seja, a questão é tratada sob a perspectiva do "vendedor" ou da empresa que deseja ofertar algo que, em tese, suprirá as necessidades de uma demanda existente (SHAW; JONES, 2005). Um dos conceitos mais importantes dessa linha de pensamento é o mix de marketing, auto creditado a Neil Borden, que em um artigo publicado em 1964, alegou que já o havia criado há 15 anos, ou seja, em 1949, inspirado em um trabalho de seu colega, Prof. James Culliton (BORDEN, 1964). No entanto, o conceito foi materializado em sua forma mais moderna por Jerome McCarthy ${ }^{23}$ (1960 apud SHAW; JONES, 2005), do qual originou os famosos "4 Ps de Marketing", e, por fim popularizado e ampliado em sentido e conexão com outras áreas da empresa por Philip Kotler (1967).

A Escola do Comportamento do Consumidor abrange o "outro lado da moeda", ou seja, o lado da pessoa que irá adquirir uma oferta (SHAW; JONES, 2005). Justamente por tratar do comportamento humano, há uma série de esforços que, em conjunto com outros campos científicos (Psicologia, Sociologia e Antropologia, valendo-se de modelos matemáticos e estatísticos para decodificação de padrões), visam a responder a uma série de questões como: qual o efeito da repetição de propagandas sobre a intenção de compra? (Psicologia pavloviana); como o consumidor toma uma decisão sob pressão de tempo e excesso de informações? (Psicologia cognitiva); de que forma figuras de autoridade e outros tipos de influência social

\footnotetext{
${ }^{23}$ MCCARTHY, E. J. Basic marketing, a managerial approach. Homewood: R.D. Irwin, 1960.
} 
determinam a opinião de uma pessoa sobre determinado produto? (Psicologia social); como diferentes classes sociais demandam diferentes formas de entrega de valor? (Sociologia); e até mesmo quais fatores determinam os rituais de consumo como os das filas que podem ser formadas por dias a cada lançamento de um novo iPhone? (Antropologia) (SHAW; JONES, 2005).

Sob essas perspectivas, apresenta-se um breve histórico da evolução do conceito de marketing ao longo do tempo, abordando, inclusive, o que está sendo adotado no presente trabalho.

$\mathrm{Na}$ história recente, é de senso comum e muito frequente relacionar marketing diretamente com "publicidade", com atividades associadas à persuasão (vender coisas que muitas vezes as pessoas não precisam) ou até mesmo com práticas antiéticas que, após averiguação, acabam resultando no veredito "isso é só marketing...”, como se marketing fosse um mecanismo de acobertamento de más práticas ou de produtos defeituosos, que se utiliza de histórias inverídicas, contadas ao público por meio de peças publicitárias.

É claro que essa fama não pode ser considerada totalmente injusta, uma vez que, por exemplo, durante anos tivemos espaço na TV dedicados a facas que cortavam "tudo" - e possuíam 54 anos de garantia! Óculos de sol que melhoravam a visão e travesseiros que prometiam curar a insônia. Tudo isso sem qualquer comprovação científica ou regulamentação de órgãos oficiais. O consumidor podia contar somente com as palavras dos próprios anunciantes e de um selo denominado "as seen on TV" ("como visto na TV") (CASTRO, 2019, tradução nossa). Independentemente da real efetividade desses produtos, sempre pairava no ar a ideia de que "isso é bom demais para ser verdade".

Todo esse poder de manipulação atribuído ao marketing praticado por empresas (aqui entendido como "propagandas potencialmente enganosas") pode ser superestimado. Para sustentação do argumento, torna-se pertinente a menção ao trabalho de Hennig-Thurau et al. (2006), cujo objeto de estudo é um filme recém-lançado (produto criativo assim como o videogame), intitulado Can good marketing carry a bad product? Evidence from the motion picture industry (“O bom marketing pode sustentar um produto ruim? - Evidências da Indústria Cinematográfica", tradução nossa).

Os resultados de modelos regressivos com dados de lançamento mostram que ações de promoção e de distribuição de um filme (parte das atividades de marketing) não são suficientes e nem determinantes para garantir seu sucesso financeiro em longo prazo. O maior impacto vem de sua qualidade percebida pelo público e pela crítica semanas, meses e até anos após seu lançamento (HENNIG-THURAU et al., 2006). 
As atividades promocionais de marketing podem até incentivar a primeira onda de espectadores e criar oportunidades para que o maior número de pessoas saiba da existência do filme e considerem assisti-lo, mas, nas semanas posteriores ao lançamento, na medida em que o boca a boca e as críticas começarem a surgir, sua qualidade passará a ser majoritariamente responsável por seu sucesso.

O marketing pode ser entendido como um ferramental importante para conectar produtos e serviços a potenciais compradores. A história mostra como sua definição evoluiu ao longo do tempo, passando de um papel puramente transacional para um componente de extrema importância para o desenvolvimento e o bem-estar social.

De 1910 a 1920, marketing referia-se basicamente à forma como um produto era distribuído e colocado em exposição em lojas varejistas (merchandising) (ZINN; JOHNSON, 1990). Ao contrário do que o senso comum poderia sugerir, as primeiras funções atribuídas ao marketing foram de distribuição, e não de promoção, por meio de peças publicitárias chamativas. Marketing sobrepunha-se a funções de logística, produção e operações, limitandose a bens físicos, tendo como atores principais de seu processo os fabricantes, os distribuidores e os varejistas.

Até 1930, o conceito envolvia a transferência de posse de produtos entre duas partes por meio de atividades de distribuição em troca daquilo que era considerado seu equivalente (CHERINGTON ${ }^{24}, 1920$ apud BRUNSWICK, 2014). É interessante notar como essa noção de "posse" seria desafiada posteriormente pela inclusão de serviços no espectro de marketing e, mais recentemente, por modelos de negócio como Airbnb e Uber.

De 1930 a 1940, houve uma separação mais clara entre as atividades de produção e as de distribuição (ainda sinônimo de marketing), incluindo todas as atividades de negócio envolvidas no fluxo de produtos e serviços do produtor ao consumidor, excluindo aquelas que envolvessem mudanças em sua forma. Essa definição também incorporava os serviços, que iam além das possibilidades físicas de oferta (MAYNARD; WEIDLER; BECKMAN ${ }^{25}, 1927$ apud BRUNSWICK, 2014).

Um grande passo para a visão mais moderna de marketing foi dado por Clark ${ }^{26}$ (1922 apud BRUNSWICK, 2014) que passou a incluir a temática do desejo, fazendo uma ponte com

\footnotetext{
${ }^{24}$ CHERINGTON, P. T. The Elements of Marketing. Nova York: Macmillan, 1920.

${ }^{25}$ MAYNARD, H. H.; WEIDLER, W. C.; BECKMAN, T. N. Principles of Marketing. New York: Ronald Press, 1927.

${ }^{26}$ CLARK, F. E. Principles of Marketing. New York: The Macmillan Company, 1922.
} 
a Psicologia e não se limitando a atividades impessoais como a transferência de posses, típicas dos domínios da economia:

\begin{abstract}
O processo de marketing, portanto, envolve tanto aspectos mentais quanto físicos mental, em que vendedores precisam saber o que os compradores desejam e compradores precisam saber o que os vendedores têm para vender - e físico, em que mercadorias precisam ser fisicamente movidas a lugares em que são desejadas no tempo em que são desejadas (CLARK ${ }^{27}$, 1922, p. 1 apud BRUNSWICK, 2014, p. 106, tradução nossa).
\end{abstract}

Ainda que não envolvesse serviços, a inclusão do desejo e as preocupações com a associação de dimensões de tempo e espaço para atendimento desses desejos marcavam uma nova era do marketing como disciplina.

De 1940 a 1960, as atribuições de marketing, limitadas aos agentes intermediários de distribuição e de varejo de produtos, incluíam comprar, vender, anunciar, transportar e estocar. Os donos da mercearia da esquina, da drogaria, da rede de lojas, da loja de departamentos, das vendas a distância, do atacadista, da ferrovia, do leiteiro e do armazém estariam todos envolvidos em atividades de marketing (CONVERSE; JONES ${ }^{28}, 1948$ apud BRUNSWICK, 2014). A ideia de "tornar públicos" os produtos (fazer sua publicidade) tornou-se mais cristalina nesse período.

No final dos anos 1960, o conceito de troca passou a ser o eixo das definições de marketing e perduraria durante as décadas seguintes. Como observado por Holloway e Hancock $^{29}$ (1968, p. 4 apud BRUNSWICK, 2014), “comprar e vender são atividades comumente associadas com trocas, ainda assim, muitas outras funções e eventos facilitam o processo de troca e esses compõem o conceito de marketing”"

Além disso, começaram a existir especificações mais precisas sobre o papel dos executivos como responsáveis pela satisfação dos consumidores via gestão (Escola de Administração de Marketing): fazer marketing passou a ser analisar, organizar, planejar e controlar recursos, políticas e atividades que impactam os consumidores, tendo em vista a satisfação de necessidades e dos desejos de grupos de clientes escolhidos com base em sua lucratividade (KOTLER, 1967). Interessante notar que a importância de selecionar clientes (escolher um público-alvo dentre segmentos distintos) surgiu neste período, mesmo limitandose somente a atividades lucrativas.

\footnotetext{
${ }^{27}$ CLARK, F. E. Principles of Marketing. New York: The Macmillan Company, 1922.

${ }^{28}$ CONVERSE, P. D.; JONES, F. M. Introduction to marketing. New York: Prentice-Hall, Inc, 1948.

${ }^{29}$ HOLLOWAY, R. J.; HANCOCK, R. S. Marketing in a changing environment. New York: John Wiley, 1968.
} 
A partir dos anos 1970, houve uma grande expansão do escopo de marketing, que passou a generalizar os elementos envolvidos na troca, envolvendo partes de diversas naturezas (indivíduos, organizações lucrativas e não lucrativas) e ofertas abstratas (serviços e até ideias). Marcus $^{30}$ (1975, p. 4 apud BRUNSWICK, 2014) definiu marketing como: "atividades realizadas por indivíduos ou organizações, lucrativas ou não lucrativas, que permitem, facilitam e encorajam a troca para satisfação das duas partes”. Markin ${ }^{31}$ (1975, p. 4 apud BRUNSWICK, 2014) complementou o conceito, definindo-o como: "um conjunto de atividades pelas quais a estrutura de demanda por produtos, ideias e serviços é gerenciada de forma a facilitar o processo de troca de forma satisfatória".

Pode-se afirmar que, a partir de 1980, houve um processo de consolidação do conceito de marketing, sustentado pelos avanços dos anos anteriores, com o objetivo de satisfazer às necessidades e aos desejos humanos (GAEDEKE; TOOTELIAN, 1983) e também dando mais espaço para as atividades de precificação. Com base nessa compreensão, a American Marketing Association (AMA) oficializou o conceito de marketing como "o processo de planejar e executar a concepção, precificação, promoção e distribuição de ideias, produtos e serviços para gerar trocas que satisfaçam objetivos individuais e organizacionais" (AMA ${ }^{32}, 1985$ apud FERRELL; LUCAS-JR, 1987, p. 15).

Esse processo perdurou durante os anos 1990, até os anos 2000, a partir de quando se constatou uma mudança estrutural do eixo de definição que substituiu a troca por valor, segundo Sheth e Uslay (2007), que argumentam, inclusive, que o conceito de troca é altamente genérico e que pode abranger uma série de atividades humanas desconexas à prática de marketing. Além disso, atividades de marketing tendem a ocorrer antes e depois da troca propriamente dita. A pura e simples finalidade de troca também tende a privilegiar táticas para ganhos de curto prazo, que não necessariamente irão satisfazer e fidelizar os consumidores (e é nesse contexto que marketing tende a surgir no imaginário popular como prejudicial).

Quanto ao valor, demonstrado pela relevância e pela capacidade de satisfação que uma oferta pode ter para o consumidor, ele está potencialmente presente em todos os pontos da cadeia produtiva (financiamento, produção, design de produtos, manutenção, garantia e outros serviços complementares) e não somente no ato da troca, sendo reconhecido geralmente pelo consumidor - mesmo não sendo sinônimo -, como o preço a ser pago por algum produto ou

\footnotetext{
${ }^{30}$ MARCUS, B. Modern marketing. New York: Random House, 1975.

${ }^{31}$ MARKIN, R. J. Marketing. New York: John Wiley \& Sons, Inc., 1979.

${ }^{32}$ AMA - American Marketing Association. AMA Board Approves New Marketing Definition. Marketing News. March 1: 1, 1985.
} 
serviço (SHETH; USLAY, 2007). O dinheiro, por sua vez, tende a ser "o valor capturado em troca ao valor oferecido pela empresa” (KOTLER; ARMSTRONG, 2007, p. 4).

Nessa perspectiva, em 2004, a AMA criou uma nova definição oficial de marketing, passando a ser "uma função organizacional e um conjunto de processos para criação, comunicação e entrega de valor a consumidores e para o gerenciamento de relacionamento com os mesmos, de forma a beneficiar a organização e seus stakeholders ${ }^{33}$ " $\left(\mathrm{AMA}^{34}, 2004\right.$ apud KEEFE, 2004, p. 17).

Ainda assim, a exclusão completa do papel da troca e a falta de clareza sobre o papel social de marketing geraram discussões por quase uma década que culminaram na mais recente definição de marketing, a qual é adotada na presente dissertação, não só pelo seu caráter oficial e histórico, mas por corresponder, de forma precisa ao contexto, a situações e aos desafios das empresas brasileiras de jogos digitais aqui estudadas, a saber: "Marketing é a atividade, conjunto de instituições e processos para criação, comunicação, entrega e troca de ofertas que possuem valor para consumidores, clientes, parceiros e à sociedade como um todo" (AMA, 2017, grifo nosso).

Sob o ponto de vista empresarial, há a necessidade de manejar (ou gerir) uma série de recursos para a correta execução de atividades de marketing, de modo a atingir os objetivos organizacionais e, simultaneamente, satisfazer clientes, consumidores e parceiros conforme estabelece a definição adotada. A seguir, serão descritos os principais aspectos relacionados à gestão de marketing nas organizações em geral.

\subsubsection{Estratégia de Marketing}

Todo o processo de gestão nasce de premissas e expectativas que podem ou não ser estruturadas de forma estratégica. Quando se delineia planos e padrões de ação em marketing, estabelece-se a chamada Estratégia de Marketing, detalhada por Varadarajan (2010, p. 128) da seguinte forma:

Estratégia de marketing refere-se ao padrão integrado de decisões de uma organização que especifica suas escolhas cruciais em relação aos mercados a serem atendidos e segmentos de mercado a serem atingidos, atividades de marketing a serem realizadas, a maneira de desempenho dessas atividades e a alocação de recursos de marketing

\footnotetext{
${ }^{33}$ Stakeholders podem ser entendidos como "partes interessadas" (empregados, clientes, acionistas, entre outros). Maiores informações disponíveis em: https://dictionary.cambridge.org/us/dictionary/english/stakeholder. Acesso em: 15 nov. 2020.

${ }^{34}$ AMA - American Marketing Association. In: "What is the meaning of 'marketing'?" MarketingNews, American Marketing Association, Chicago, p. 17-18, September 15, 2004.
} 
entre mercados, segmentos de mercado e atividades de marketing para a criação, comunicação e/ou entrega de um produto que ofereça valor aos clientes nas trocas com a organização e, assim, permita à organização alcançar objetivos específicos.

A Figura 8 abaixo representa os componentes de uma estratégia de marketing e seu inter-relacionamento, tendo como premissa básica e finalidade a geração de valor para o cliente, com o intuito de criar um relacionamento sustentável, indo além de uma simples transação.

Figura 8 - Estratégia de Marketing e o Mix de Marketing

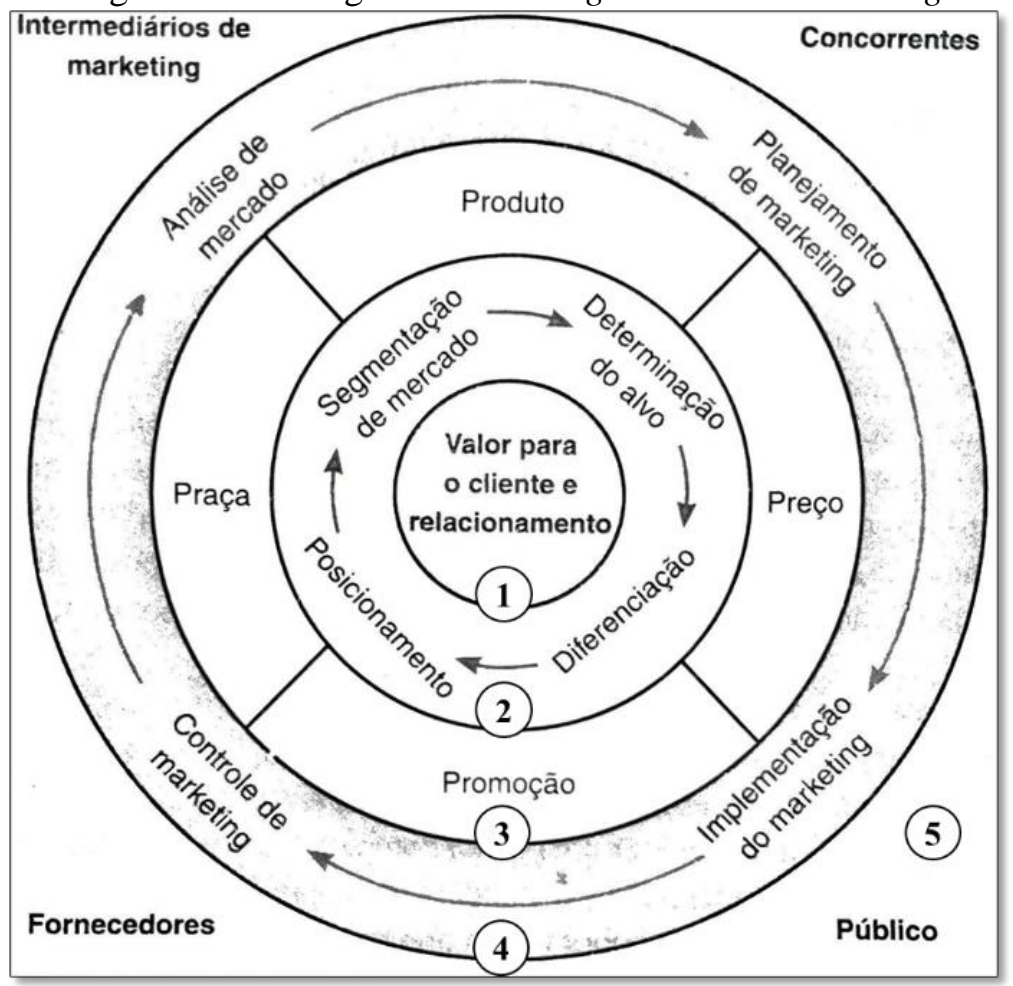

Fonte: Kotler e Armstrong (2007, p. 39), numeração nossa.

A seguir, cada camada do esquema apresentado (Figura 8, números de 1 a 5) será decomposta, começando por seu núcleo (camada 1) e avançado para as áreas mais externas, procurando esclarecer quais os principais aspectos que os gestores de marketing das organizações precisam levar em consideração para dar cabo a ações dessa natureza. Além disso, também serão considerados os 3 Ps adicionais de Marketing de Serviços, dada a sua aderência ao contexto das empresas aqui estudadas. 


\subsubsection{Valor para o cliente e relacionamento}

Conforme abordado anteriormente, marketing, em sua forma mais incipiente, apresentase como uma resposta aos desafios de distribuição por conta do desenvolvimento de produtos em massa derivado de uma grande demanda urbana emergente, ou seja, a transferência de mercadorias, a posse e a estocagem eram as principais preocupações de gestores de empresas para a otimização de processos e rotinas.

A célebre frase de Henri Ford reflete a mentalidade do início do século XX: "o cliente pode ter o carro da cor que quiser, contanto que seja preto" (FORD; CROWTHER, 1922, p. 72, tradução nossa). Essa "indiferença" a certos desejos dos consumidores pode ser atribuída a circunstâncias específicas e ao nível de maturidade do mercado, praticamente irreprodutíveis nos tempos atuais.

Tendo como exemplo o mercado automobilístico daquela época, destacam-se dois fatores: o primeiro refere-se à uma demanda reprimida, com necessidade de locomoção, mas sem acesso a veículos motorizados, por serem restritos a ricos e influentes entusiastas daquela nova tecnologia; o segundo, à inexistência de concorrentes para atendimento à demanda popular por automóveis. A combinação de ambos os fatores facilitou a entrada da Ford no mercado com seu modelo T, tendo como principal vantagem o fato de ser financeiramente acessível, devido ao processo de produção inovador. A sua missão era baratear ao máximo o custo de produção e atender a todo o mercado.

Essa forma de atuação não é mais praticável na maioria dos mercados atuais, pois há muitas empresas disputando a atenção e os "bolsos" dos consumidores. O próprio mercado automobilístico passou a ser foco de intensa concorrência, exigindo que as empresas entreguem mais valor para o cliente e se preocupem centralmente com o relacionamento estabelecido (camada 1 da Figura 8), o que pode ser traduzido, inclusive, como outras possibilidades de cores, por exemplo.

Mesmo assim, há grande risco de as organizações concentrarem-se muito mais no desenvolvimento de seus produtos e nos processos e se esquecerem de atender aos desejos e às necessidades dos consumidores. Uma empresa de jogos digitais, por exemplo, pode dedicar muito tempo ao desenvolvimento de um jogo que não será apreciado pelo público, por não ter prestado atenção suficiente nas características do mercado ou por não ter testado adequadamente seus conceitos e protótipos junto aos potenciais jogadores. Esse fenômeno é conhecido como 'miopia de marketing', identificado há décadas por Theodore Levitt, e detalhado em um artigo homônimo de 1960 e publicado novamente em 1984 (LEVITT, 1984). 


\subsubsection{Da segmentação ao posicionamento}

Levando-se em consideração o acirramento da concorrência, tem-se que "empresas não podem servir de forma lucrativa a todos os clientes de um mercado". Nesse caso, considera-se 'mercado' como "o conjunto de compradores reais e potenciais de um produto" (KOTLER: ARMSTRONG, 2007, p. 40). Surge, então, a noção de segmentação de mercado, que presume que cada qual possui certos grupos de consumidores similares entre si em determinadas características e desejos e que, por sua vez, são diferentes de outros grupos com outras características e desejos (SMITH, 1956).

Considerando-se que no mercado de videogames há pessoas que preferem jogos de corrida de automóveis e outras que preferem jogos de estratégia, temos, então, um primeiro corte que geraria dois segmentos. Obviamente, os desafios de segmentação são enormes, pois, em um primeiro momento, não há como saber o seguinte:

a) se o tipo de jogo é uma variável decisiva para separar os grupos ou se há outra variável mais importante como "dispositivo utilizado" - jogadores de smartphones x jogadores de consoles, por exemplo. Pode ser também que a resposta esteja na combinação de duas ou mais variáveis;

b) se é possível identificar e dimensionar o tamanho de cada segmento com precisão, pois é necessário manipular dados estatísticos, realizar pesquisas e conhecê-los profundamente; e

c) se podem existir "subsegmentos" ou segmentos mais específicos dentro de um segmento já identificado, por exemplo, entre os amantes de jogos de corridas, é possível que existam aqueles que gostem de jogos que simulem condições reais de direção de automóveis e outros que prefiram uma experiência mais fantasiosa como carros voadores ou super velozes.

A partir do momento em que a empresa consiga identificar os potenciais segmentos de mercado e dimensioná-los em tamanho e rentabilidade potencial, há a oportunidade de escolher um ou mais segmentos - trata-se da escolha de seu "público-alvo" ou "targeting". Geralmente, essa decisão está condicionada à capacidade da empresa de atender a um ou mais segmentos.

Algumas empresas possuem a capacidade de atender a vários segmentos distintos, a partir da criação de inúmeras ofertas ou de uma oferta básica que minimamente atenda a todos. Um número significativo de empresas possui limitações que exigem a escolha de segmentos específicos (ou nichos) para não dispersar sua capacidade produtiva ou para ocupar um território que a concorrência desprezou. O que mais importa nesse caso é que "a empresa deve 
ter como alvo segmentos que ela possa gerar de forma lucrativa o mais alto valor para o cliente e manter esse valor ao longo do tempo" (KOTLER; ARMSTRONG, 2007, p. 40).

Essa mentalidade confronta-se diretamente com a mentalidade fordista do início do século XX, uma vez que há empresas como a General Motors que afirma que fabrica um carro para cada tipo de "pessoa, bolso e personalidade" (KOTLER; ARMSTRONG, 2007, p. 41).

A partir da definição clara de público, a empresa deve estabelecer determinado posicionamento, que envolve deixar claro o que sua oferta é (ou não) capaz de fazer. É o encontro entre o que a marca quer representar e o que as pessoas pensam de fato sobre sua marca. Posicionar-se envolve comunicar quais atributos da sua oferta representam uma diferenciação em relação às ofertas concorrentes, fazendo parte da gestão da marca - ou branding $^{35}$ (RIES; TROUT, 2009).

O posicionamento também especifica para quem e em quais circunstâncias seus produtos ou serviços devem ser consumidos (RIES; TROUT, 2009). O efetivo posicionamento é capaz de ocupar "espaços" específicos na mente do consumidor onde são ativados "gatilhos" para a recordação imediata de algumas marcas, por exemplo: "fast-food" rapidamente associado ao McDonald's; "experiência de compra online" associada à Amazon; "refrigerante da felicidade e da reunião familiar" associado à Coca-Cola (FRAKENTHAL, 2018), entre outros.

$\mathrm{Na}$ indústria de jogos, isso pode ser um fator definidor de sobrevivência: a Sony e a Microsoft, por exemplo, estão trabalhando em linhas distintas de posicionamento na nova geração de consoles (Playstation 5 e Xbox Series X/S, respectivamente). A primeira está indo pelo caminho mais tradicional de criação de jogos exclusivos e a segunda, apostando em uma experiência mais focada na assinatura de jogos diversos a serem acessados em múltiplos aparelhos (PETERS, 2020).

Todo esse processo descrito, que envolve a segmentação, a escolha do público-alvo, a diferenciação e o posicionamento, refere-se à camada 2 da Figura 8.

\subsubsection{Mix de marketing: os 4 Ps}

Kotler e Armstrong (2007, p. 42) definem mix de marketing como "o conjunto de ferramentas de marketing táticas e controláveis que a empresa combina para produzir a resposta que deseja no mercado-alvo. Consiste em tudo o que a empresa pode fazer para influenciar a

\footnotetext{
35 Branding é um campo amplo de marketing e limitar-se-á à temática do posicionamento. Para melhor entendimento de outros aspectos de branding, consultar TYBOUT; CALKINS. Branding. São Paulo: Atlas, 2006.
} 
demanda de seu produto", ou seja, trata-se dos elementos operacionais e práticos guiados pela estratégia geral de criação de valor para o público-alvo selecionado.

Esses elementos foram agrupados em 4 grandes grupos de variáveis caracterizados como os 4 Ps: Product, Price, Place e Promotion (Produto, Preço, Praça e Promoção), conforme ilustra a camada 3 da Figura 8 e, em maiores detalhes, a Figura 9 a seguir.

Figura 9 - Os 4 Ps do Mix de Marketing

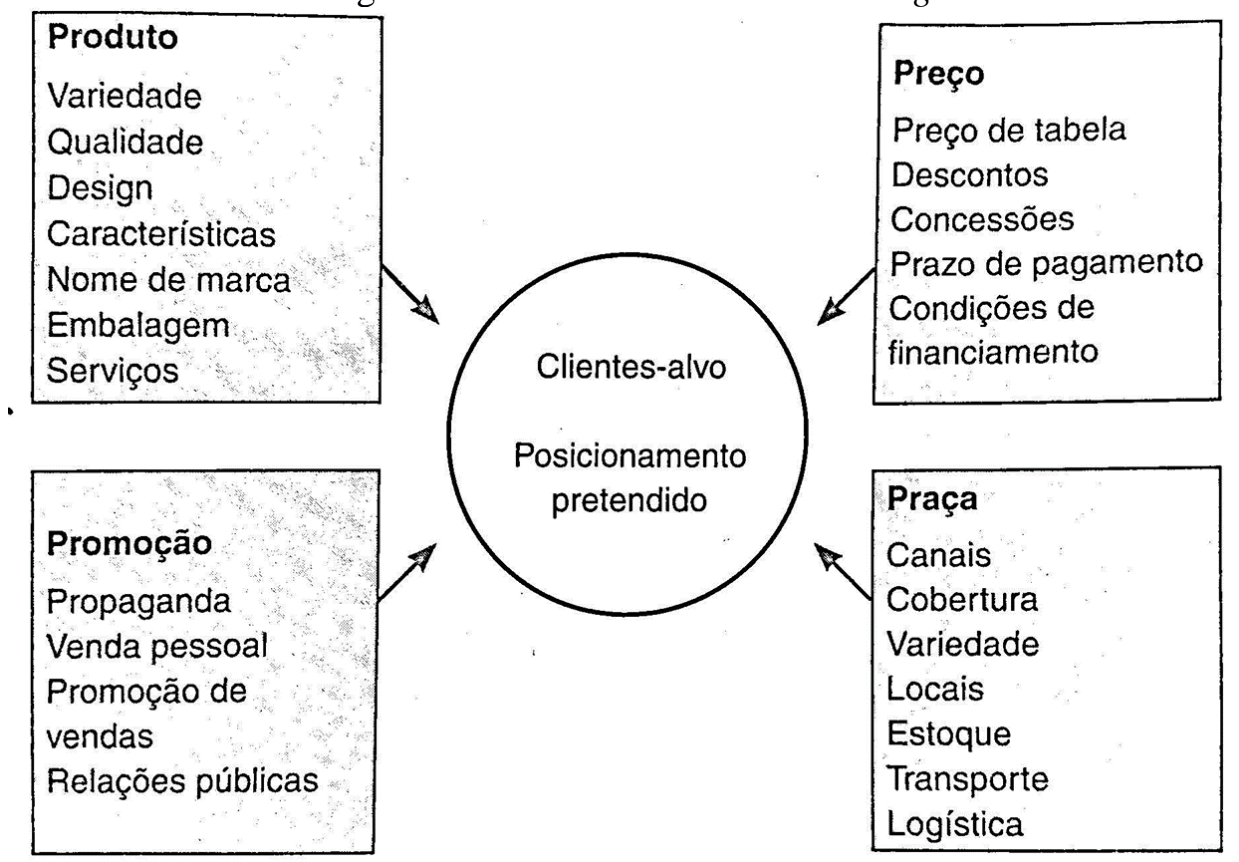

Fonte: Kotler e Armstrong (2007, p. 42).

i) Produto

É definido como "a combinação de bens e serviços que a empresa oferece ao mercadoalvo" (KOTLER; ARMSTRONG, 2007, p. 42). Em senso comum, o produto pode ser associado a um artefato palpável, que pode ser embalado, transportado e entregue ao consumidor final. No entanto, numa definição mais moderna e ampla de produto, consideram-se também outros tipos de oferta que têm potencial para gerar valor e para receber valor em troca como: seguros, passagens aéreas, estadias em hotéis, férias, shows, cinema, crédito bancário, entre outros. Tais experiências e serviços não podem ser embalados, estocados e fisicamente entregues (no máximo em forma de "passaporte" de consumo do serviço como cartões de crédito, apólice de seguro, ingressos etc.), mas podem ser combinados em um conjunto de benefícios e características que compõem um Produto, satisfazendo as necessidades e os desejos dos consumidores. 
Sendo assim, um videogame é, sob a perspectiva de marketing, um produto que combina tanto os elementos físicos quanto os abstratos, definido por Esposito (2005, p. 16) como "um jogo que podemos jogar por meio de um aparato audiovisual”. Esse aparato audiovisual (a parte física ou hardware) é o responsável por possibilitar a interação de seres humanos com um sistema computadorizado (ou software ${ }^{36}$ ) ficcional, muitas vezes imprevisível, com atividades que possuem regras, em espaço e tempo delimitados.

A experiência completa com um videogame depende da combinação de elementos que formam um ou mais produtos e serviços em um esforço para gerar valor para o jogador. Por exemplo: um jogo como o Candy $\mathrm{Crush}^{37}$, que é um software com regras e objetivos do tipo tile-matching ${ }^{38}$, pode ser considerado de forma isolada como um produto. No entanto, sua geração de valor ao consumidor final depende de outros produtos, serviços e empresas que viabilizam seu consumo como: os smartphones produzidos pela Samsung e pela Apple; as lojas online, como a PlayStore do Google, que disponibilizam o pacote programado do jogo para download a milhões de pessoas em todo o mundo; sem contar os serviços locais de Internet de cada região e as empresas que estão por trás dos recursos de transações financeiras online. Essa é uma pequena demonstração da complexidade e da interdependência de uma intrincada rede de valor que os desenvolvedores de jogos precisam manejar para finalmente entregarem seu "produto" ao consumidor final.

Em resumo, um produto é um composto de elementos e características capazes de satisfazer os desejos e as necessidades de determinados públicos e pode ser avaliado em função de atributos como: variedade, qualidade, design, marca, embalagem e serviços (KOTLER; ARMSTRONG, 2007), que por sua vez dependem de outros produtos de outras empresas, avaliados sob os mesmos (ou outros) critérios para expressarem o máximo de sua utilidade, valor e também de seus diferenciais.

\footnotetext{
${ }^{36}$ Software é a parte intangível, que "diz" o que o computador, o console ou o celular deve fazer. O jogo digital em si (ou videogame) é um software que compõe o conjunto de regras e desafios que os jogadores devem superar. Maiores informações disponíveis em: https://www.britannica.com/technology/software. Acesso em: 10 de mar. 2021.

${ }^{37}$ Candy Crush é um jogo do tipo free-to-play do gênero match-three puzzle (uma variação da mecânica tilematching) lançado pela empresa King, em 2012. Maiores informações disponíveis em: https://www.king.com/game/candycrush. Acesso em: 20 mar. 2021.

${ }^{38}$ Tile-matching (ou combinação de peças, tradução nossa) é um tipo de jogo no qual o jogador deve manipular as peças para fazê-las desaparecer de acordo com um critério de correspondência (encaixe, cor etc.). A quantidade de peças determina a variação do nome (exemplo: match-three puzzle). Um exemplo clássico é o Tetris, lançado em 1984, por Alexey Pjitnov. Maiores informações disponíveis em: https://tetris.com/history-of-tetris. Acesso em: 20 mar. 2021.
} 
ii) Preço

É o único elemento do mix de marketing com potencial de produzir receita (os demais elementos só geram custos). Kotler e Armstrong (2007, p. 258) definiram preço como "a quantia em dinheiro que se cobra por um produto ou serviço”. Essa definição é muito simplista, considerando-se a dinâmica das relações comerciais atuais e outros ramos do marketing como o marketing político, no qual o candidato e seu plano de governo podem ser considerados o "produto" e o voto, o "preço" a ser pago pelo eleitor. Seria uma abstração que envolveria tanto o esforço de se locomover ao local de votação quanto as consequências em sua comunidade pela eleição de um determinado candidato (CWALINA; FALKOWSKI; NEWMAN, 2011).

Sob essa perspectiva, não se perderá de vista a noção mais ampliada do conceito de preço (como o esforço envolvido e as dificuldades enfrentadas para se fazer o download de um jogo, quando este é gratuito), mas a abordagem de pesquisa irá se concentrar nos aspectos financeiros mais tangíveis das empresas brasileiras de jogos digitais, tendo em vista a natureza mais ampla das atividades de marketing contempladas pelo presente estudo e não somente as atividades de precificação. Além disso, as dificuldades de geração de receitas relatadas anteriormente no subitem 2.2 MERCADO NACIONAL E INTERNACIONAL exigem um olhar mais focado no tema sob essa perspectiva.

Definir o preço de um produto ou de um serviço não é uma tarefa fácil, pois o "preço baixo" não é garantidor de sucesso, haja vista as marcas de luxo cujos atributos incluem altos preços como expressão de status e exclusividade. Desconsiderando-se mercados mais “extremos", os desafios de um gestor de marketing geralmente estão na determinação do preço ideal, ou seja, no preço que garanta os custos de produção da oferta e que gere lucro, mas que também não seja tão elevado a ponto de afastar a demanda.

A determinação do preço ideal pode passar por uma série de técnicas e análises, resumidas por Nagle, Holden e Zale (2016) como uma determinação de preços baseada nos custos em oposição a uma determinação de preços baseada em valor.

A determinação de preço baseada nos custos é estabelecida a partir da somatória dos custos envolvidos em uma oferta, aplicada uma margem de lucro a partir de critérios diversos. Essa é uma abordagem que pode deteriorar a percepção de valor do cliente em longo prazo, além de fazer com que a empresa perca oportunidades de lucro com o oferecimento de vantagens além do preço baixo. Ainda assim, há mercados extremamente competitivos em que a expressão de máximo valor vem do menor preço possível, tornando o modelo aplicável dentro de uma estratégia clara que determine prazos e escopos desse tipo de atuação. 
A determinação de preços baseada no valor é considerada um fator fundamental para a determinação de preço sob o ponto de vista do marketing moderno (KOTLER; ARMSTRONG, 2007), pois a empresa trabalhará o preço sob a perspectiva do consumidor e não do produto. Essa abordagem pode trazer benefícios em longo prazo, pois irá sempre levar em consideração o preço que o consumidor estará disposto a pagar pelo produto e não somente seu custo de produção. Obviamente que, se o custo de produção for maior do que o preço que o consumidor está propenso a pagar, a empresa deverá rever sua proposta, eliminando elementos da oferta que a encareçam ou adicionando outros que justifiquem um preço mais elevado.

Para os desenvolvedores de videogames, há uma complexidade adicional por conta dos diferentes modelos de precificação atuais, que não se resumem somente à venda direta de um jogo ao consumidor (chamado one time payment), destacando-se dentre eles as micro transações que se popularizaram nos jogos mobile, geralmente gratuitos, que fornecem opções de funcionalidade para avançar no jogo, conteúdos exclusivos ou artefatos cosméticos - novas cores e formas, roupas, acessórios, personagens, ferramentas, armas, entre outros, por meio de pagamento em dinheiro real (AKGOZ, 2019).

Estudos como os de Kim, Hollingshead e Wohl (2016) têm procurado entender as motivações e as circunstâncias envolvidas nessa modalidade de consumo, levantando interessantes questões sobre as regras e as formas de funcionamento desse microambiente econômico virtual. Há também modelos de assinatura (pagamento anual) para acesso a determinados jogos ou a catálogos de jogos, conteúdos adicionais que se conectam a um jogo já adquirido e que precisam ser baixados (DownLoadable Contents - DLCs) ou, não menos populares, a combinação entre diversos modelos.

iii) Praça

Trata-se do ecossistema de disponibilização da oferta ao consumidor final: canais de distribuição, locais físicos (e virtuais) nos quais a oferta está disponível, transportes e logística (KOTLER; ARMSTRONG, 2007). No caso dos videogames, a PlayStore ${ }^{39}$ do Google faz parte da estratégia de praça de uma série de empresas que disponibilizam seus jogos, assim como as lojas de shopping centers que disponibilizam mídias como DVDs e Blu-rays jogáveis. Basicamente, uma estratégia de praça tem a função de facilitar a entrega de valor ao

\footnotetext{
${ }^{39}$ Maiores informações disponíveis em: https://economictimes.indiatimes.com/blogs/et-commentary/the-newplatform-model-google-play-store-stylel. Acesso em: 20 mar. 2021.
} 
consumidor, controlando variáveis de escopo, tempo e espaço (o quê, quando e onde a oferta será entregue e o valor que será gerado a partir de tal configuração). Em resumo, trata-se de entregar o produto ou o serviço onde está o consumidor final. Com o advento de novas tecnologias, a "praça" para videogames é potencialmente o mundo inteiro, por meio da distribuição digital.

iv) Promoção

Trata-se de um dos mais complexos ramos do marketing, tanto que Kotler e Keller (2006) referem-se a esse 'P' como um mix dentro do Mix de Marketing. Além de todas as possíveis atividades de marketing, as de promoção são as que tendem a ter maior impacto e contato com públicos que não necessariamente estão em busca ativa pelo produto ou serviço. Constitui-se, assim, a parte mais visível do marketing ou a "ponta do iceberg".

Promover um produto ou serviço significa torná-lo público, comunicá-lo efetivamente, para atrair a atenção das pessoas. Nessa linha de raciocínio, é muito natural que haja conexão imediata com propagandas de TV ou, mais recentemente, anúncios online. No entanto, há 6 (seis) formas essenciais de promoção (KOTLER; KELLER, 2006), a saber:

I) Publicidade e Propaganda: como Kotler e Keller (2006) deixam transparecer na edição de seu livro em português, publicidade e propaganda não são sinônimas, no entanto, não é objetivo do presente trabalho aprofundar nessa temática, mas deixar claro que utilizaremos o termo 'Publicidade' por maior aderência ao nosso contexto e por possuir um caráter mais comercial em oposição ao caráter mais ideológico do termo 'Propaganda' (GOMES, 2001). A publicidade é, portanto, “qualquer forma paga de apresentação e promoção não pessoais de mercadorias, serviços ou ideias por um anunciante identificado" (KOTLER; KELLER, 2006, p. 533).

II) Promoção de vendas: incentivos de curto prazo para estimular uma experimentação ou compra de um produto ou serviço. Há, por exemplo, empresas de jogos que disponibilizam uma parte do jogo gratuitamente (ou um dia específico de acesso grátis) para incentivar a compra das demais partes.

III) Eventos e experiências: atividades patrocinadas pela empresa para criar interações do público com a marca em dias específicos ou de forma recorrente. Desenvolvedoras de 
jogos podem alugar espaços em eventos como nas feiras Brasil Game Show e Big Festival $^{40}$ para mostrarem seus lançamentos ou para criarem outras experiências que chamem a atenção para seus jogos.

IV) Relações públicas e assessoria de imprensa: são atividades que procuram gerenciar e proteger a imagem da empresa e de seus produtos mediante os principais meios de comunicação do setor. Uma empresa de videogames pode, por exemplo, anunciar para a imprensa ou para youtubers seu novo jogo por meio de press releases, além de disponibilizar cópias de teste gratuitas.

V) Marketing direto: é uma abordagem personalizada que, geralmente, exige uma resposta direta e prática. Atualmente, e-mail, redes sociais, comunidades online e outros recursos da Internet são os meios mais comuns de contato direto com consumidores. Exemplo: envio de um link para download da versão alpha (versão de teste) de um jogo a um público específico. Há ainda meios diretos como telemarketing e correios em outros setores, mas, há algum tempo, não aparentam ser algo comum para jogos.

VI) Vendas pessoais: uma das mais antigas formas de comunicação que exigem interação pessoal para apresentação ou demonstração de produtos e serviços. Com base no contexto atual, vendas virtuais (via videoconferências e afins) podem ser enquadradas nessa categoria.

Em resumo, um gestor de marketing deverá procurar extrair ao máximo de cada um dos Ps do mix de marketing, de modo a compor uma estratégia integrada de entrega de valor ao consumidor. Robert Lauterborn (1990, p. 17) propôs os chamados 4 Cs, abordando uma perspectiva do ponto de vista do consumidor: Cliente (solução para o), Custo (para o cliente), Conveniência e Comunicação, mas ela não será abordada em detalhe por conta do olhar majoritariamente empresarial proposto pelo presente estudo.

\footnotetext{
${ }^{40}$ Sites oficiais: Brasil Game Show. Disponível em: https://www.brasilgameshow.com.br/. Acesso em: 2 dez. 2020 e Big Festival. Disponível em: https://www.bigfestival.com.br/. Acesso em: 2 dez. 2020.
} 


\subsubsection{Marketing de serviços}

Como visto anteriormente, o marketing foi fundado sob as bases da distribuição de mercadorias físicas, fazendo com que acadêmicos como Booms e Bitner (1981) passassem a se preocupar com a aplicabilidade dos 4 Ps de marketing em operações de serviços.

Vale pontuar que os serviços são oficialmente entendidos como ofertas que possuem 4 (quatro) principais características: intangibilidade - não é algo que pode ser efetivamente "tocado"; inseparabilidade - a entrega e consumo da oferta não podem ser separados; heterogeneidade - alta variação da qualidade e das possibilidades de entrega a depender do momento ou dos locais onde se executa o serviço; e perecibilidade - um serviço não pode ser armazenado, transportado ou "guardado para depois" (REGAN, 1963; RATHMELL, 1966; SHOSTACK, 1977; ZEITHAML; PARASURAMAN; BERRY, 1985).

Um videogame pode ser visto como um produto (em seu sentido mais "palpável") ou como um serviço ou como a mistura de ambos, conforme sinalizado anteriormente. Apesar de a "tangibilidade" ser um exercício complexo, dada a natureza da oferta, entende-se que há possibilidades de consumo, sem a dependência do executor do serviço (os desenvolvedores de jogos, por exemplo) e sua transferência de um local para outro, sua armazenagem (física ou virtual) e outras características que poderiam enquadrá-lo como uma mercadoria tradicional.

Por outro lado, um videogame online, por exemplo, depende de uma infraestrutura de serviços dedicada, que funcione geralmente 24 horas por dia, e que seja responsável pela manutenção, atualização e execução da experiência (que pode variar muito dependendo de vários fatores, como: equipamento utilizado, qualidade da Internet e capacidade do servidor) (SHAIKH et al., 2004). Essa situação enquadra-se em todas as 4 (quatro) principais caraterísticas de um serviço.

Esse entendimento traz a necessidade de uma perspectiva teórica que também contemple os avanços científicos em marketing aplicados a serviços. Assim, descreveremos a seguir mais 3 (três) componentes do mix de marketing que associados aos 4 (quatro) componentes clássicos formam os 7 Ps do marketing de serviços (BOOMS; BITNER, 1981). São eles: People, Process e Physical evidence (Participantes, Processos e Evidência física).

i) Participantes (ou Pessoas)

São tanto os próprios consumidores quanto os colaboradores que estão prestando os serviços. A preocupação é quanto à interface entre esses dois públicos e às condições de 
execução do serviço para o público consumidor. A busca é pela melhor experiência possível e pela garantia de execução do serviço. Por exemplo: garantir que o jogador encontre uma vaga em uma partida online no menor tempo possível e que eventuais reclamações, dúvidas e outras solicitações sejam devidamente tratadas e solucionadas por colaboradores capacitados e motivados.

ii) Processos

Referem-se a todos os procedimentos, políticas e, especialmente, aos fluxos de execução do serviço. O que o jogador precisa fazer para ter acesso ao jogo? Quanto tempo isso pode demorar para não gerar resistência? Quais os incentivos para sua permanência? O que fazer com os jogadores que estão há mais de 10 dias sem acessar o jogo? Etc.

iii) Evidências físicas

Referem-se aos artefatos que tornam o serviço "tangível” e são importantes na avaliação da qualidade do serviço por parte do consumidor. No mundo dos games, os aparelhos audiovisuais (consoles, computadores ou celulares), os DVDs e outros periféricos (como controles, mouses e teclados) são exemplos de evidências físicas extremamente importantes para a composição da experiência do usuário. São aspectos que, em boa medida, estão fora de controle da maioria das empresas desenvolvedoras de jogos, pois dependem geralmente de outras empresas e das possibilidades de aquisição dos consumidores.

\subsubsection{Inteligência de marketing}

Uma função da área de marketing, que costuma sustentar planos, implementações e controle (gestão de marketing) são as análises (camada 4 da Figura 8) realizadas a partir de vários métodos, cumprindo vários objetivos e compondo o que se pode chamar de sistema de inteligência de marketing, o qual pode coletar dados de uma série de partes e de fontes de interesse (clientes, fornecedores, concorrentes, governos, entre outros), tratá-los e analisá-los para cumprimento de seus objetivos de curto, médio e longo prazos (KOTLER; KELLER, 2006).

Uma desenvolvedora de jogos pode ter interesse em conhecer melhor seu mercado consumidor. Para isso, pode acessar dados públicos, privados ou conduzir um levantamento 
próprio com a finalidade de saber a quantidade de jogadores ativos na região, os gêneros mais jogados, a média de gasto por jogo adquirido, entre outras informações. Essa prática está inclusa no universo da pesquisa de marketing e pode servir tanto para identificar problemas (potencial e participação de mercado, imagem de marca, análise de vendas, tendências etc.), como para solucionar problemas (segmentar o mercado, melhorar um produto, ajustar o preço, aumentar a eficiência da comunicação, entre outros) (MALHOTRA, 2006).

O gestor deve entender que há diferentes linhas de atuação e camadas ambientais que precisam ser consideradas em sua avaliação para suportar as tomadas de decisão (camada 5 da Figura 8). Para simplificar, costuma-se separar os ambientes de marketing em micro e macro ambientes (KOTLER; ARMSTRONG, 2007).

No microambiente estão presentes a própria empresa, os fornecedores, os intermediários de marketing, os clientes, os concorrentes e outros públicos de interesse (acionistas, governos, sindicatos, associações, mídia etc.). O macro ambiente pode ser entendido como um conjunto de fatores que exercem 'força' sobre a atuação da empresa e que são menos passíveis de controle. Esses fatores são geralmente resumidos como tendências ou características sociais, econômicas, políticas, tecnológicas, culturais, demográficas e até naturais de um determinado mercado (KOTLER; ARMSTRONG, 2007).

No que diz respeito ao microambiente, um gestor de uma desenvolvedora de jogos pode coletar dados de vendas diretamente da Google Play Store ${ }^{41}$ (em seu papel de intermediária) para avaliar a performance de suas vendas na plataforma. Ao mesmo tempo, pode avaliar reclamações e opiniões de seus usuários, transformando-as em ações de melhoria e em atualização de seus jogos.

Quando se trata de avaliar o macro ambiente, o desenvolvedor pode procurar por mudanças sociais estruturais que estão ditando as maneiras mais comuns de consumos de jogos (a tendência mobile é um exemplo concretizado, enquanto a realidade aumentada e outras formas de interação ainda estão em desenvolvimento).

\subsection{GESTÃO DE MARKETING DIGITAL}

Um jogo pode ser praticado de várias formas: com cartas, com bolas, com papéis, com figurinhas, com cordas ou com a memória. Um videogame é, por natureza, um jogo que se opera

\footnotetext{
${ }^{41}$ Site oficial disponível em: https://play.google.com/store. Acesso em: 19 mar. 2021.
} 
com a assistência de um computador ou de outro dispositivo eletrônico, online ou offline, ou seja, um 'jogo digital' como definem Brkljačić et al. (2019).

O marketing digital, por sua vez, envolve o uso de canais sociais ou digitais para promover uma marca ou alcançar consumidores. Este tipo de marketing pode ser executado na internet, mídias sociais, motores de busca, dispositivos mobile e outros canais (AMA, 2020).

Apesar de a natureza do produto ou do serviço não determinar por si só o tipo de marketing a ser realizado, é natural que produtos digitais fluam com certa naturalidade em ambientes onde se executam atividades de marketing digital. O nível de conveniência de aquisição (canais), velocidade de transação (preço), formas de abordagem dinâmicas e personalizadas (promoção) e versatilidade de consumo (produto) podem fazer a diferença entre os produtos "analógicos" e os "digitais" (ANDRONICO, 2017).

Além disso, em sua forma mais básica, o marketing digital pode representar para pequenos negócios e startups uma forma mais barata de interação com o mercado consumidor, com possibilidades de alcance de audiências globais, adaptação de mensagens, construção de relacionamento e mensuração de resultados com menor emprego relativo de recursos financeiros, humanos e técnicos. No entanto, na medida em que as metas e a evolução das técnicas de interação e de relacionamento com o consumidor vão se aprimorando, os custos também vão passando a ser maiores (AMA, 2020).

Segundo Castells (2019), houve uma revolução da Tecnologia da Informação a partir do início da década de 1970, que ditou os novos rumos do capitalismo global, o chamado 'Capitalismo Informacional', que foi além do uso da informação como parte do processo de produção, mas como o próprio produto resultante e fonte de valor do processo produtivo. Com a popularização da Internet no final da década de 1990, somada à ebulição de centros de inovação ao redor do mundo (como o Vale do Silício, nos Estados Unidos, que sediou a inovadora e não convencional Atari), passou-se a observar uma nova dinâmica no desenvolvimento de produtos e serviços.

Desde então, a Internet converteu-se em um gigantesco ecossistema de trocas e de interações, acessada por 3,5 bilhões de pessoas ao redor do mundo (ROSER; RITCHIE; ORTIZ-OSPINA, 2020), gerando uma quantidade tão grande de dados que, se fossem gravadas em CD-ROMs empilhados, "resultaria em uma torre que alcançaria Marte... e ainda voltaria..." (LO and Behold: Reviers of the Connected World, 2016, tradução nossa). Por consequência, a forma como praticar gestão de marketing nesse mundo digitalizado e intenso em informações passou por mudanças significativas, algumas das quais descritas e avaliadas nos próximos subitens deste Capítulo. 


\subsubsection{Metodologias Ágeis}

Com abordagem inspirada em modelos de gestão de organizações dos anos 1950, as metodologias ágeis de gestão popularizaram-se, a partir da década de 1990, aplicadas, a princípio, ao desenvolvimento de softwares, por suas características adaptativas, interativas, incrementais e orientadas a pessoas (ABBAS; GRAVELL; WILLS, 2008).

A metodologia ágil é adaptativa, no sentido de mudar, em pouco tempo, seus próprios métodos de solução de problemas em resposta aos novos desafios. Ela é interativa e incremental por não dividir o produto em várias partes independentes, mas por desenvolver, a cada fase, versões funcionais do mesmo. Por exemplo, um protótipo simples, mas funcional, de um jogo é elaborado em poucos dias no lugar de uma parte não funcional que se integraria à versão final vários meses depois (sem muitas garantias de sucesso).

A metodologia ágil é orientada a pessoas, pois foca em tornar o ambiente de trabalho propício para que especialistas tomem as melhores decisões dependendo do contexto e não de uma preocupação excessiva com normas de conduta, protocolos ou posições hierárquicas (ABBAS; GRAVELL; WILLS, 2008).

A expressão "metodologias ágeis" sugere corretamente a existência de mais de uma metodologia, uma delas é a Scrum, criada por Ken Schwaber e Jeff Sutherland, no início dos anos 1990, como "uma estrutura leve que ajuda pessoas, equipes e organizações a gerar valor por meio de soluções adaptativas para problemas complexos" (SCHWABER; SUTHERLAND, 2020).

A filosofia ágil de geração de protótipos, ao invés da clássica divisão de tarefas para conclusão de um produto, tende a se mostrar altamente eficiente nesse contexto, pois sua abertura para mudanças estruturais é fundamental para a resolução de problemas de marketing digital, conforme verificado no estudo de Moi e Cabiddu (2020).

Uma empresa desenvolvedora de jogos pode, por exemplo, procurar resolver um problema de perda de interesse do jogo a partir de uma fase específica (ou churn). Um Product Owner (PO) passará à equipe os principais problemas e objetivos envolvidos (SCHWABER e SUTHERLAND, 2020). Parte dessas atividades envolverá um conhecimento mais profundo das características e dos padrões de comportamento dos jogadores no mundo virtual, que seriam funções de marketing digital e de pesquisa de marketing. Mas, ao invés de realizar uma grande pesquisa com milhares de players e encaminhar a solução aos desenvolvedores, profissionais de marketing, designers, artistas e programadores podem trabalhar juntos em diversos protótipos das fases a serem testadas até que seja encontrada uma solução de maior eficiência. 
Do contrário, haveria uma grande chance de a única e final solução proposta, após a realização de uma grande pesquisa, continuar não sendo a mais adequada para a solução do problema.

\subsubsection{Publicidade Programática}

A Publicidade Programática (Programmatic Advertising), conhecida no meio publicitário brasileiro como Mídia Programática, é uma forma de publicidade digital que corresponde a "um processo de leilão em grande escala e em tempo real, por meio do qual os anúncios são atribuídos automaticamente aos espaços disponíveis em vários tipos de mídia e regiões geográficas, mediante solicitação individual do navegador do usuário" (ALAIMO; KALLINIKOS, 2018, p. 1).

Para melhor compreensão do que vem a ser a Publicidade Programática, a forma mais simples é compará-la com os meios tradicionais de publicidade. Geralmente, o processo tradicional (inclusive em algumas negociações na Internet) inicia-se com um anunciante interessado em comprar um espaço em determinado veículo de comunicação (por exemplo, uma rede de supermercados que reserva um banner "clicável" na página principal em um site de notícias por um dia inteiro), ou seja, ele faz a escolha do veículo supondo o impacto em seu público-alvo.

Com a introdução de plataformas como o Google e Facebook, a compra passou a ganhar mais inteligência, com base em grupos impactados de pessoas com interesses em comum. No caso do Google, o anunciante pode expor seu anúncio em lugares de destaque para pessoas que pesquisam certas palavras-chave. Já no Facebook, é introduzida a possibilidade de compra de mídia para se comunicar com usuários que possuem interesses em comum, por exemplo, "videogames". A dinâmica de compra se dá por meio de um leilão onde, de maneira simplificada, o anunciante com maior lance ganha a oportunidade de mostrar seu anúncio ao público de interesses em comum.

Com a Mídia Programática, o sistema torna-se mais sofisticado: primeiramente, é definido o público-alvo (manualmente ou com o auxílio de rotinas computadorizadas que realizam testes de efetividade) e a seguir, os esforços de mídia são distribuídos entre diversos veículos e espaços de publicidade online que irão atingir precisamente os indivíduos selecionados com as características determinadas.

A definição de custo pelo espaço também é realizada a partir de um leilão, mas é realizado automaticamente por algoritmos que permitem ao anunciante efetuar lances diferentes para cada um dos indivíduos a serem impactados e não somente para todo um grupo com 
interesses em comum. Por exemplo: dois anunciantes querem atingir o mesmo indivíduo no mesmo site ao mesmo tempo. Quem pagar mais, conseguirá expor seu anúncio ao "alvo" (Figura 10).

Figura 10 - Diferenças entre tipos de mídia no meio online

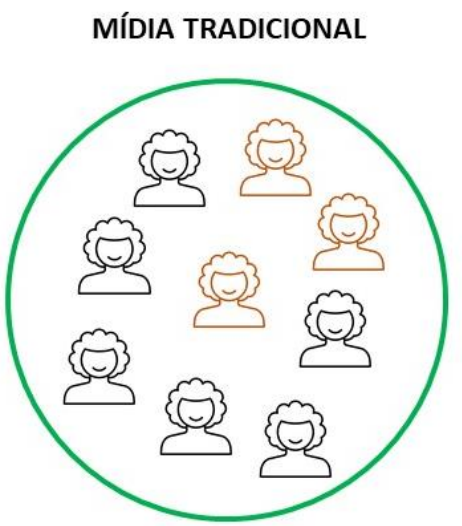

$\mathrm{R} \$ 10$

Investimento alto no qual apenas parte do impacto está no público alvo. $\mathrm{O}$ valor é pago independentemente da assertividade.
MÍDIA DIGITAL

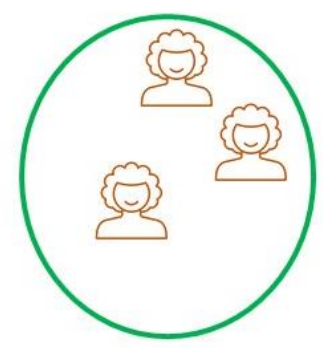

$\mathrm{R} \$$
MÍDIA PROGRAMÁTICA

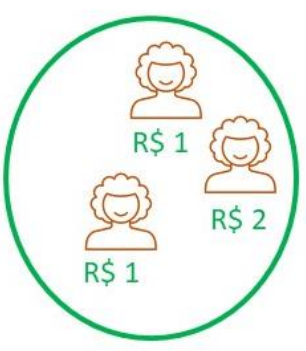

$\mathrm{R} \$ 4$
Investimento é feito apenas no público alvo. O valor é pago por um grupo, independentemente do potencial de cada indivíduo ou leilão.
Investimento é feito indivíduo a indivíduo. O valor é pago proporcionalmente ao potencial de cada leilão.

Fonte: Elaborada por Bruno Oliveira ${ }^{42}$ (2021), com base em valores fictícios.

A grande diferença está na precisão e na rentabilidade do investimento. Se por um lado, a mídia tradicional investe um valor para ter uma grande dispersão e impactar apenas parte do seu target, as ferramentas de mídia digital melhoram isso com a possibilidade de fazer leilões para indivíduos agrupados. Porém, a mídia programática vai além e permite que, cada indivíduo em cada site e no mesmo momento, seja parte de um "micro" leilão que acontece em milésimos de segundo e otimiza as campanhas de uma maneira que seria impossível se somente fosse efetuada por seres humanos, sem o auxílio de algoritmos e "robôs" digitais.

O meio no qual esse leilão ocorre, denominado Ad Exchange, envia o sinal para o sistema de compra de espaço programático para o anunciante (Demand Side Platform - DSP) (Figura 11). Esse sinal informa que há um concorrente pagando mais pelo espaço "programado" e oferece ao sistema de compra do anunciante a opção de aumentar o lance. A decisão de aumentar ou de desistir do lance, em geral, é feita automaticamente, com base em metas de retorno sobre o investimento e limites de "custo por clique" ou "custo por mil impressões", determinados previamente por operadores humanos.

\footnotetext{
${ }^{42}$ Bruno Oliveira é Co-founder \& Partner da Adsplay, empresa especializada em Mídia Programática no Brasil. Dados meramente explicativos para o contexto da presente dissertação, não publicados.
} 
Quanto à máquina “entender” que cobrir um lance, naquele contexto, para aquela pessoa específica, "valerá a pena" é uma decisão geralmente tomada com base em um profundo conhecimento da audiência em questão, a partir de dados fornecidos por um terceiro sistema, a Data Management Platform (DMP). Quanto maiores forem a quantidade e a qualidade das informações sobre aquela pessoa (demografia, hábitos de consumo, comportamento web, padrão de jornada de consumo, histórico de compras prévias no caso de clientes etc.), mais precisas e mais rentáveis serão as decisões de compra de espaço online feitas pela DSP. Tudo isso ocorre em questão de segundos, milhares de vezes por minuto e praticamente sem interferência humana durante a ação (MATCH2ONE, 2021).

Figura 11 - Principais componentes da Publicidade Programática

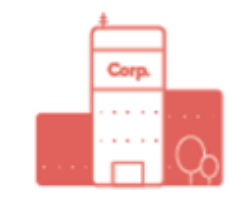

BRAND / ADVERTISER

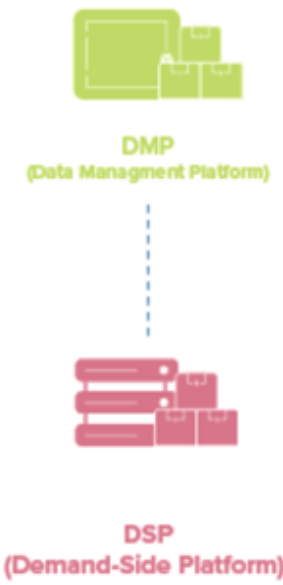

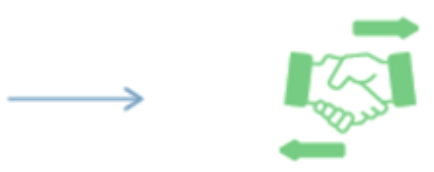

AD EXCHANGE

Fonte: match2One.com (2021, n.p.).

Por exemplo: uma empresa desenvolvedora de jogos realiza uma pesquisa que define os "jogadores de First Person Shooter - FPS" ${ }^{43}$ como seu público-alvo. A DMP irá coletar dados na rede com variáveis que irão auxiliar a traçar esse perfil. Ao ser "informada" pela $A d$ Exchange que um concorrente está comprando um espaço online para atingir uma mesma pessoa do mesmo público, a DSP irá tomar a decisão de cobrir ou não o lance ao "formular algumas perguntas" a serem "respondidas" pela DMP, tais como: quantas pessoas com esse perfil estão disponíveis na Internet em outros espaços? Seu potencial gasto no jogo irá compensar o novo valor pago para atingi-lo? Qual é a probabilidade de se estabelecer um relacionamento de longo prazo com esse indivíduo em relação a outros públicos? Para

\footnotetext{
${ }^{43}$ Conhecido no Brasil como "tiro em primeira pessoa", o FPS é um gênero de videogame no qual o jogador assume o campo de visão do protagonista. É possível "enxergar com seus olhos", ver seus braços, sua arma e o ambiente com os inimigos a serem abatidos. Maiores informações disponíveis em: https://www.dictionary.com/browse/first-person-shooter. Acesso em: 15 mar. 2021.
} 
responder a essas perguntas e tomar as melhores decisões, a DMP do anunciante precisa fornecer dados mais precisos do que a DMP da concorrência, ou seja, "ganha" o leilão quem detiver a informação mais qualificada. Além disso, os sistemas podem fazer inúmeros testes de anúncios criativos (visual e mensagens) e selecionar automaticamente os mais efetivos para garantirem a conversão de seus públicos de interesse.

É claro que se trata de um sistema altamente sofisticado e de difícil acesso, até mesmo para as grandes empresas. As versões mais acessíveis de compra de mídia digital e programática são serviços fornecidos pelo Facebook Ads (THE DRUM, 2017) e pelo Google Ads (GOOGLE, 2020a) para micro e pequenos negócios, que permitem acesso a seu inventário (usuários do Facebook e visitantes de sites afiliados ao Google) em uma interface relativamente simples (selecionando o público desejado, pagando um valor máximo por clique ou por conversão e acompanhando os resultados). Mesmo com certas limitações, há a vantagem de se pagar quantias muito menores por impacto, quando comparadas com os métodos tradicionais de publicidade.

\subsubsection{Gestão de Relacionamento com o Cliente - CRM}

Desde que o marketing passou a reconhecer o consumidor como ponto de partida para as estratégias e as práticas organizacionais e as tecnologias da informação tornaram-se cada vez mais presentes no dia a dia das organizações, começaram a surgir alguns equívocos ou entendimentos distorcidos em torno do conceito de Gestão de Relacionamento com o Cliente (ou Customer Relationship Management - CRM) os quais serão esclarecidos antes de relacioná-los com a indústria de interesse deste estudo.

Digitando no Google a sigla "CRM", é provável encontrar uma série de referências a sistemas de gestão e de softwares que prometem melhorar o relacionamento de empresas com seus clientes. Na verdade, as ferramentas são a consequência de um processo elaborado a partir de uma estratégia que compõe a gestão de relacionamento e não a completa definição de CRM (REINART; KRAFFT; HOYER, 2004). Esse tipo de associação também induz à crença de que se trata de um conceito completamente ligado ao mundo digital, o que não é verdade.

Dessa forma, há três conceitos que precisam ser previamente esclarecidos: Marketing de Relacionamento (Relationship Marketing), Gestão de relacionamento com o consumidor (CRM) e Gestão de Clientes (Customer Management), conforme esquema proposto por Frow e Payne (2009), apresentado na Figura 12 a seguir. 
Figura 12 - Marketing de Relacionamento, CRM e Gestão de Clientes

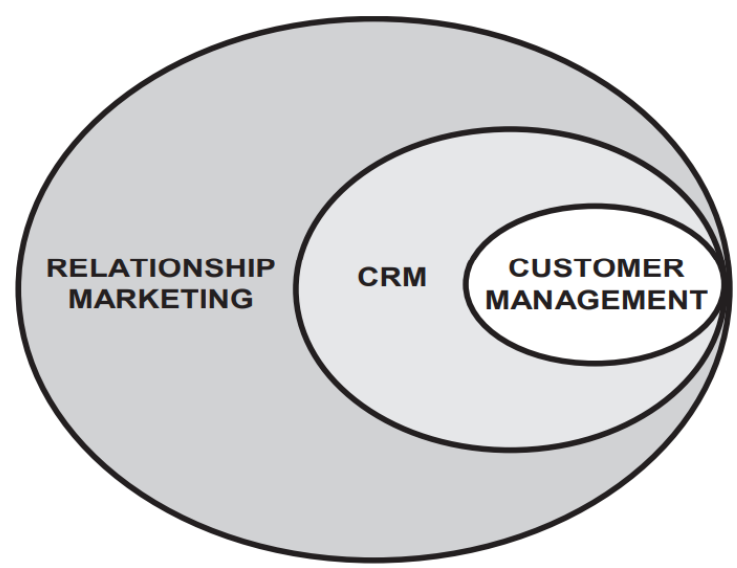

Fonte: Frow e Payne (2009, p. 10).

Conforme sugerido pelo esquema acima, o Marketing de Relacionamento (Relationship Marketing) é o ponto de partida, uma visão estratégica de relacionamento com todas as partes interessadas da empresa (acionistas, fornecedores, governo, imprensa etc.) e não somente com os consumidores. O objetivo é obter o máximo de valor possível dessas relações, a partir da identificação de grupos e subgrupos-chave, e gerir adequadamente tais relações em uma complexa e grande rede de relacionamentos (FROW; PAYNE, 2009).

CRM acaba sendo, tal como o Marketing de Relacionamento, uma gestão estratégica de relacionamento, mas limitada ao consumidor.

\begin{abstract}
CRM é uma abordagem estratégica multifuncional preocupada com a criação de valor para o acionista por meio do desenvolvimento de relacionamentos apropriados com clientes e segmentos de clientes. Normalmente envolve a identificação de estratégias de negócios e clientes adequadas, a aquisição e difusão de conhecimento do cliente, decidindo a granularidade de segmento apropriada, gerenciando a (co)criação de valor para o cliente, desenvolvendo estratégias de canal integradas e o uso inteligente de soluções de dados e tecnologia para criar experiências superiores (FROW; PAYNE, 2009, p. 11, tradução nossa).
\end{abstract}

É interessante destacar o importante papel da tecnologia e do uso de dados nessa definição, pois são formas de reduzir as complexidades inerentes a grandes operações que geram interações com milhares (se não milhões) de consumidores simultaneamente. Um dos jogos mobile (e de computador) mais populares da atualidade, por exemplo, é o Among $U s^{44}$, 'baixado' por mais de 8 milhões de pessoas somente na Google Play (GOOGLE, 2020b). Se é difícil imaginar o grau de dificuldade de gerir o relacionamento com algumas dezenas de

\footnotetext{
${ }^{44}$ Among Us é um jogo multijogador online que se baseia em informações assimétricas (“quem é o impostor?”). Foi lançado pela Inner Sloth LLC, em 2018.
} 
pessoas, quem dirá com milhões delas, sem o uso intensivo de tecnologia e da gestão de dados que se associa profundamente à gestão de marketing digital.

A gestão de clientes (Customer Management) é a vertente operacional do CRM que se preocupa com os aspectos mais táticos, incluindo o uso de ferramentas tecnológicas para gerir campanhas, automatizar força de vendas e fazer atendimento personalizado (FROW; PAYNE, 2009), como o uso de chat bots ${ }^{45}$.

Dessa forma, a correta gestão de relacionamento online de uma desenvolvedora de jogos com seus jogadores deverá partir de uma perspectiva estratégica mais abrangente (Marketing de Relacionamento e CRM) para depois se preocupar com o uso da ferramenta "X" ou "Y" de gestão de clientes.

\subsubsection{Big Data e Data Science Marketing}

Sistemas de inteligência de marketing nunca foram tão necessários a organizações que geram e que têm acesso a grandes quantidades de dados e que são constantemente desafiadas a transformá-los em informações úteis e operacionalizáveis. É muito comum ouvir o termo Big Data como uma expressão relacionada a todo e qualquer tipo de dado coletado via Internet, o que não é verdadeiro.

Expressando numericamente, um volume de dados considerado tipicamente como Big Data gira em torno de 1 (um) terabyte (SCHROECK; SHOCKLEY; SMART, 2012). O Facebook, por exemplo, em 2010, já armazenava 260 bilhões de fotos, o que é equivalente a 20 mil terabytes ou 20 petabytes (BEAVER et al., 2010). Esse conceito abarca também a variedade, que está relacionada à existência de dados estruturados, semiestruturados e desestruturados, além da velocidade, que está associada a seus períodos de atualização que, em determinados contextos, pode ocorrer em frações de segundo.

A maioria dos videogames produzidos atualmente, em especial os que permitem interações online, tem a capacidade de coletar uma imensa quantidade de dados (alto volume) a cada segundo (alta velocidade) provenientes de múltiplos tipos de interação (alta variedade). O grande desafio está na adequada coleta e conversão destes dados em informações inteligíveis e práticas para as equipes que queiram adotar ações de marketing digital.

\footnotetext{
${ }^{45} \mathrm{Um}$ chat bot é um software programado para realizar o atendimento ao cliente, em substituição a atendentes humanos. Geralmente, utiliza-se de um histórico de perguntas frequentemente realizadas por clientes para dar respostas padronizadas. Alguns contam até com algoritmos de inteligência artificial e aprendem novas respostas e formas de interação por meio de rotinas de aprendizado. Maiores informações disponíveis em: https://take.net/blog/chatbots/chatbot\#botia. Acesso em: 29 nov. 2020.
} 
Para tanto, tem-se recorrido ao que se convencionou chamar Ciência de Dados, termo que compreende um conjunto de competências que, quando isoladas, são historicamente consolidadas, mas, quando juntas, podem compor formas inéditas de explorar diversas áreas, incluindo a de marketing. Waller e Fawcett (2013, p. 78) definem Ciência de Dados como a "aplicação de métodos quantitativos ou qualitativos para resolução de problemas e predição de resultados".

O executor de Ciência de Dados é o Cientista de Dados. Davenport e Patil (2012) explicam que se trata de um profissional possuidor de um conjunto de habilidades técnicocientíficas direcionadas à resolução de problemas do mundo das organizações. Não se trata somente de um programador ou de um estatístico a ser contratado para manipular tecnologias e informações de grandes bancos de dados, trata-se de um profissional híbrido, que é, ao mesmo tempo, um data hacker, um analista, um comunicador e um confiável consultor de negócios. Davenport e Patil (2012, p. 1) ressaltam que se trata de "uma combinação extremamente poderosa e rara de competências".

Um Cientista de Dados, em uma desenvolvedora de jogos, pode ser capaz de reunir dados de diversas fontes, incluindo Big Data, tratá-los, analisá-los e transformá-los em um sistema de inteligência capaz de atingir objetivos de marketing como: atração, aumento de conversão, desenvolvimento de engajamento e lealdade, diminuição da desistência (churn), aumento da satisfação etc.

\subsection{GESTÃO DE MARKETING NAS INDÚSTRIAS CRIATIVAS}

Primeiramente, antes de se conceituar Indústrias Criativas, faz-se necessário definir o que é um trabalho criativo. Runco e Jaeger (2012) publicaram um estudo cuja finalidade foi encontrar as mais proeminentes definiçõoes de trabalho criativo na literatura acadêmica. Dentre as definições apresentadas, uma das que mais se destaca, por sua capacidade de generalização e abrangência, é a de Stein (1953, p. 311, tradução nossa). Segundo ele,

O trabalho criativo é um trabalho novo aceito como sustentável, útil ou satisfatório por um grupo em algum momento no tempo. Por novo quero dizer que o produto criativo não existiu anteriormente com a mesma forma... O trabalho é novo na medida em que se desvia do tradicional ou do status quo. Isto dependerá da natureza do problema a ser atacado, o nível de conhecimento preexistente no campo de conhecimento em questão e as características tanto do indivíduo criador quanto dos indivíduos com os quais o mesmo se relaciona. 
Com isso em mente, é possível concluir que nem todo trabalho é criativo e, por extensão, nem todo produto ou indústria o será (pelo menos de forma majoritária, frequente e constante), existindo uma clara separação entre Indústrias Criativas e outros tipos de indústrias. O presente trabalho adotará a definição de Indústrias Criativas elaborada pelo Department for Digital, Culture, Media \& Sport (DCMS), do Governo do Reino Unido (2001, p. 5, grifo nosso): “[Indústrias criativas são] aquelas indústrias que têm sua origem na criatividade, habilidade e talento individuais e que têm potencial de geração de riqueza e empregos por meio da geração e exploração de propriedade intelectual".

Assim, Indústria Criativa é a que possui como "matéria-prima" a criatividade (um recurso intelectual) e depende da mesma para sua sobrevivência (sua fonte de valor econômico). Uma Indústria Criativa deve, portanto, ser intensiva em pessoas e fundar suas bases em sua capacidade de subverter as lógicas existentes e tidas como padrão. Bendassolli et al. (2009) destacam 4 (quatro) principais características dessa tipologia de indústria:

- Criatividade [prática]: é a expressão da capacidade humana de realizar, manifestada pela criação de produtos tangíveis. Ou seja, é a capacidade que uma pessoa possui de manipular objetos do mundo externo em um processo simultâneo de desenvolvimento de seus recursos pessoais, suas fantasias e seus desejos;

- Valorização da arte pela arte: ainda que haja potencial conflito entre as instâncias criativas e as instâncias funcionais típicas dos sistemas de gestão das indústrias tradicionais, as concepções estéticas e artísticas das Indústrias Criativas têm forte influência sobre as escolhas e o direcionamento de recursos;

- Uso intensivo de novas tecnologias: a Indústria Musical é um bom exemplo de como as novas tecnologias revolucionaram a forma como a música é produzida, distribuída e consumida, o que levou grandes conglomerados de gravadoras à falência. Outro exemplo é o esgotamento do modelo de distribuição da Blockbuster, que cedeu espaço para tecnologias mais avançadas, como os serviços de streaming de filmes e de séries da Netflix;

- Uso extensivo de equipes polivalentes: como a criatividade e a falta de linearidade do processo de produção ditam o ritmo dessas organizações, há necessidade de os profissionais envolvidos possuírem diferentes habilidades e especialidades e que consigam manejar os mais diferentes recursos, exigindo flexibilidade e domínio de múltiplas disciplinas. 
As Indústrias Criativas são, na prática, empresas que lidam, entre outras possibilidades, com atividades relacionadas ao teatro, ao cinema, à música, às artes plásticas, à moda e aos videogames (BENDASSOLLI et al., 2009). Transferindo a lógica para a criação de videogames, uma empresa desenvolvedora de jogos digitais possui no âmago de suas responsabilidades o desenvolvimento de um produto novo a ser entendido como satisfatório pelo público-alvo (os jogadores). Cada produção acumula um conhecimento preexistente e um referencial amplo de técnicas já utilizadas, mas, ao mesmo tempo, precisa trazer elementos inovadores que capturem a atenção. Sem criatividade, a Indústria Criativa não existe e, consequentemente, também não existe a Indústria de Jogos Digitais.

\subsubsection{Marketing nas Indústrias Criativas}

As Indústrias Criativas, dadas as suas características distintivas das demais indústrias, trazem à tona aspectos específicos de marketing. Essas características, segundo TROILO (2015), são as apresentadas na Figura 13 a seguir.

Figura 13 - Características distintivas das Indústrias Criativas

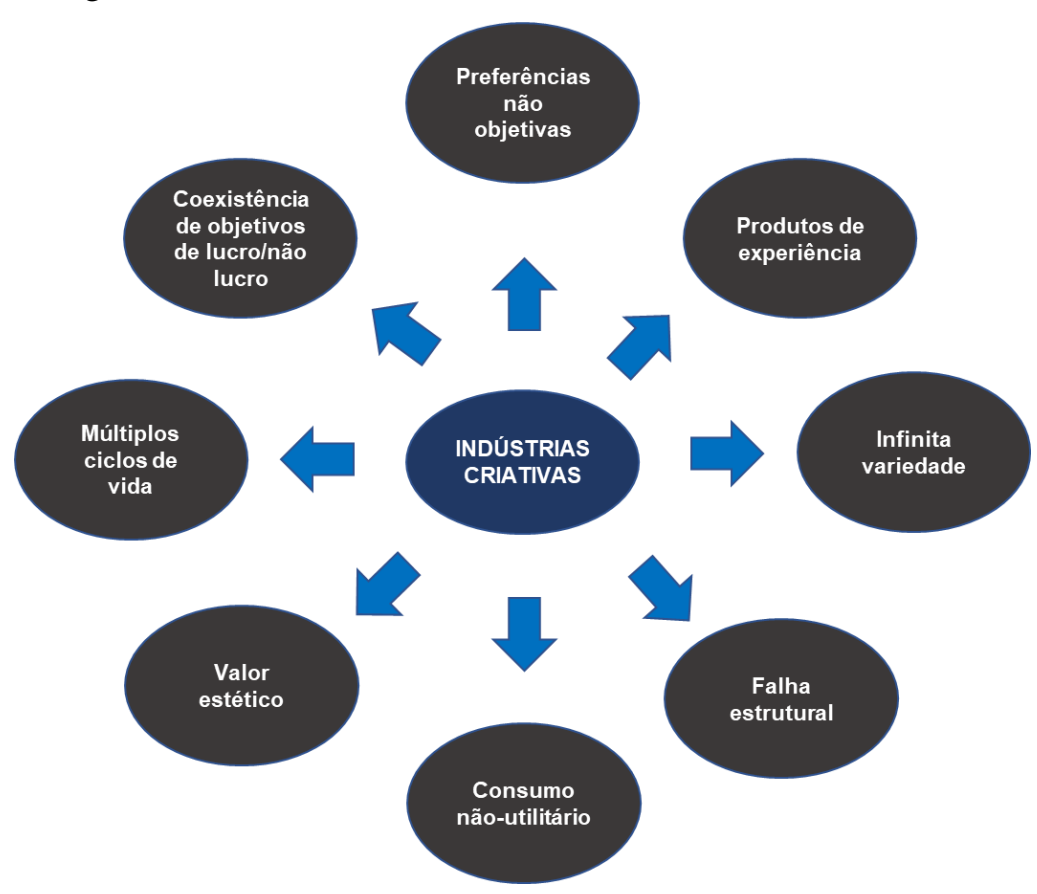

Fonte: Adaptado de Troilo (2015, p. 11, tradução nossa).

De acordo com Troilo (2015), um produto de qualquer indústria pode ser escolhido por seus atributos tangíveis e/ou intangíveis. O ponto focal é que, no caso das Indústrias Criativas, o peso da intangibilidade, ou das preferências não objetivas, é muito maior. Por exemplo: um 
carro, para um consumidor com uma orientação mais racional, pode ser avaliado e escolhido em termos objetivos e funcionais (potência do motor, presença de ar condicionado, tamanho do porta-malas etc.). No entanto, um videogame dificilmente poderá ser escolhido apoiando-se única e exclusivamente em seus atributos funcionais (qualidade gráfica, número de frames por segundo, velocidade de carregamento etc.), pois a satisfação com o produto depende de sua capacidade de imersão em uma espécie de experiência pouco palpável e de difícil mensuração.

É notável, por exemplo, o esforço e a grandiosidade da produção de um jogo como o Watch Dogs ${ }^{46}$ (custo de US\$68 milhões de dólares), mas o primeiro título da franquia desapontou tanto a crítica especializada quanto o público em geral por ter uma história clichê, formatos de missões pouco desafiadoras, entre outras coisas (POOLEY, 2014). Um produto criativo é primeiramente avaliado por seu valor hedônico, experimental e simbólico, ou seja, por suas características não-utilitárias de consumo. Dentre essas características, está o grande peso da estética, onde a beleza e a agradabilidade visual podem ser até mais diferenciais do que outros atributos.

Isso leva a outra conclusão: um produto criativo é um produto de experiência e não de busca. Não é possível saber se de fato o produto irá agradar as pessoas antes de ser consumido. Isso pode também ser verdade para produtos de outras indústrias, mas é possível que se tenha mais evidências de funcionalidade e de qualidade para um produto que está sendo comercializado há mais de 50 anos em um supermercado do que de um filme que acabou de ser lançado. Além disso, a chance de existirem opiniões contraditórias a respeito de um produto criativo pode ser maior quando comparado com outros tipos de produtos. Dessa forma, as Indústrias Criativas são altamente dependentes da reputação de marcas ou de pessoas (exemplo: “esse filme parece ser bom, afinal quem dirige é o Christopher Nolan" ${ }^{47}$ ).

Um produto criativo possui uma 'infinita variedade' e possibilidades de substitutos (ir ao cinema, ao teatro ou ficar em casa lendo um livro?). Se quiser se vestir de acordo com a 'moda', há várias lojas, marcas, estilos e cortes de roupa que oferecem diferentes versões desse conceito, com variadas propostas de valor (exclusividade, reconhecimento social, luxo etc.). Essa 'infinita variedade' está altamente associada a uma falha estrutural inerente aos produtos e serviços oferecidos, pois há muita oferta para uma demanda que não cresce no mesmo ritmo.

\footnotetext{
${ }^{46}$ Watch Dogs é um jogo de ação e aventura em mundo aberto desenvolvido e publicado pela Ubisoft em 2014. Maiores informações em: https://www.ubisoft.com/en-gb/game/watch-dogs/watch-dogs. Acesso em: 02 nov. 2020.

${ }^{47}$ Cristopher Nolan é um diretor, escritor e produtor inglês premiado por trabalhos cinematográficos como A Origem (2010), a trilogia Batman - O Cavaleiro das Tevas (2005, 2008 e 2012), Interestelar (2014) e, mais recentemente, Tenet (2020). Maiores informações disponíveis em: https://www.imdb.com/name/nm0634240/. Acesso em: 01 dez. 2020.
} 
Fazendo referência especificamente a jogos mobile, em 2015, já se estimava a produção de 750 jogos por dia (GRAFT, 2015). Ainda que o mundo jogue em torno de 1 bilhão de horas por mês, é muito difícil conquistar a atenção e o engajamento destes jogadores, pois há muitas opções disponíveis (VERKASALO, 2020). Este não é somente um problema para pequenos produtores e desenvolvedores de jogos; grandes produtoras lançam muitos jogos que fracassam antes mesmo que surja um blockbuster. A Rovio produziu 52 jogos malsucedidos e quase foi à falência antes de lançar o hit Angry Birds ${ }^{48}$, segundo Peter Vesterbacka, CEO da empresa ${ }^{49}$ (2012 apud FRIED, 2012).

Um produto criativo também possui múltiplos ciclos de vida: um hit musical pode durar alguns dias, algumas semanas, alguns meses ou, mais raramente, alguns anos ou décadas. Assim também ocorre com filmes, videogames ou estilos de roupa. Essa dificuldade de previsão da obsolescência é um grande desafio para organizações criativas, que precisam planejar seus recursos de produção do produto, precificação, promoção ou distribuição.

Por fim, mas não menos desafiadora, é a coexistência de objetivos associados ou não ao lucro. Uma empresa criativa, geralmente, está intimamente associada a aspectos culturais e a missões que podem ir além do lucro (bem-estar social, conscientização ambiental, educação, lazer, entre outros) ou até mesmo pode ter um elevado senso artístico e independente, que faz com que os produtos não sejam somente modelados em função da demanda, mas feitos para expressarem os valores e os sentimentos de seu criador. Ou seja, há uma dificuldade em distinguir um produto de uma 'obra'.

\subsubsection{Marketing em Empresas de Jogos Digitais}

A própria ideia de criar um instrumento de entretenimento como um videogame gera um estado de animação e de expectativas que pode dissociar o empreendedor de responsabilidades como avaliar e segmentar o mercado; colocar o produto à prova; entender as reais necessidades dos consumidores e criar sistemas adequados de precificação e de distribuição, que vão muito além da pura e simples divulgação do jogo. Para Zackarisson e Wilson (2012), por ser um produto cuja matéria-prima é a criatividade, é natural que o(a) desenvolvedor(a) se enxergue mais como um(a) "artista" e menos como um(a) "executivo(a)

\footnotetext{
${ }^{48}$ Angry Birds é um jogo do gênero casual puzzle lançado pela Rovio Entertainment, em 2009. Maiores informações disponíveis em: https://www.angrybirds.com/. Acesso em: 10 mar. 2021.

${ }^{49}$ Informação de Peter Vesterbacka em entrevista concedida a FRIED, conforme consta nas Referências Bibliográficas.
} 
de negócios", criando barreiras a estratégias e práticas de marketing. Essa questão traz a necessidade de adaptações e flexibilizações da atuação de marketing nessas organizações.

A efetiva e produtiva participação de um profissional de marketing em uma organização criativa pode exigir um nível maior de envolvimento e de experiência com esse tipo de produto do que seria necessário em outras indústrias. Assim, é desejável para o sucesso da organização que esse e os outros profissionais envolvidos no projeto sejam verdadeiros gamers, segundo Zackarisson e Wilson (2012). Isso porque o videogame pode ser considerado o mais complexo "brinquedo" inventado até então. Uma boneca, por exemplo, pode possuir algumas dezenas de respostas a certos comandos, um videogame, por sua vez, quando conectado a um computador, pode fornecer milhões delas (ESPOSITO, 2005).

Além do processo de desenvolvimento da oferta em si, aspectos técnicos de precificação e de distribuição também precisam ser incorporados à rotina de um profissional de marketing dessa indústria, pois os rumos de uma estratégia de marketing podem depender diretamente do tipo de plataforma a ser utilizada (console, PC ou mobile) ou da forma como o jogo será precificado (por compra única, micro transações, conversões de moedas por país, entre outros) (ZACKARIASSON; WILSON, 2012). Cada plataforma possui suas potencialidades ou limitações técnicas (o que se faz em um computador pode não ser feito no celular ou viceversa), exigindo que as expectativas do público sejam calibradas de acordo com tais requisitos.

Em resumo, a execução de atividades de marketing nesse tipo de organização pode estar condicionada a especificidades não verificadas em outras indústrias, exigindo que o profissional de marketing esteja muitas vezes um nível acima da média de adaptação, flexibilidade e conhecimento técnico.

\subsubsection{Marketing em MPEs de Jogos Digitais}

O cenário é desafiador para a execução de atividades de marketing em uma empresa de jogos digitais relativamente consolidada e, em se tratando de micro e pequenas empresas, há uma camada adicional de complexidade. Chiavenato (2008, p. 15) elenca fatores como inexperiência do empreendedor, condições econômicas adversas e despesas operacionais como causadores de mortalidade de micro e pequenas empresas brasileiras de forma geral.

Essa natural escassez de recursos técnicos, humanos e financeiros desse tipo de empresa traduz-se no cenário observado pelo Segundo Censo da Indústria Brasileira de Jogos Digitais (MINC, 2018), que aponta a falta de recursos adequados e de investimentos financeiros efetivos em marketing e vendas, pela necessidade de foco no desenvolvimento da oferta em si e também 
pelo histórico acadêmico, geralmente atrelado às Ciências da Computação ou à Tecnologia da Informação, deixando os fundadores inseguros ou indiferentes a grandes ações de marketing e de vendas de seus produtos.

Por outro lado, a democratização de acesso às tecnologias e às ferramentas de marketing no mundo digital proporciona aos pequenos negócios a oportunidade de executarem atividades de marketing de forma mais intuitiva, fluída e com custos mais baixos (GILMORE; GALLAGHER; HENRY, 2007).

Há também a possibilidade de terceirizar atividades de marketing por meio de agências de publicidade ou empresas que produzem e publicam os jogos (publisher ${ }^{50}$ ), consideradas melhores opções para micro e pequenas empresas, pois podem assumir os riscos de lançamento ao financiarem a produção do jogo em troca da parte de possíveis ganhos futuros. Isso pode permitir que a empresa desenvolvedora concentre sua energia e seus recursos na atividade fim, mas também pode gerar complexidades como o balanço entre o ímpeto artístico e criativo do empreendedor, as expectativas comerciais e a necessidade de controle da publisher (TSCHANG, 2007).

\footnotetext{
${ }^{50}$ Publishers ou publicadoras são as empresas que geralmente produzem e publicam os jogos.
} 


\section{PROCEDIMENTOS METODOLÓGICOS}

Resolver problemas e entender processos, práticas e padrões de marketing de forma eficaz passa por uma visão científica que deve priorizar a verdade sobre quaisquer preconcepções ou interesses dos pesquisadores. Para Hair-Jr et al. (2005), a Ciência da Administração - e por consequência a Gestão de Marketing -, deve seguir os princípios da "boa" ciência, caracterizada como:

- Empírica: comparável com a realidade;

- Reproduzível ou objetiva: a opinião do pesquisador é independente dos resultados; outros pesquisadores encontrariam os mesmos resultados se utilizassem os mesmos métodos e na mesma situação (mas não necessariamente com a mesma interpretação para o fenômeno);

- Analítica: segue o método científico na separação e descrição dos fatos;

- Dirigida pela teoria: fundamenta-se no conhecimento científico prévio;

- Lógica: as conclusões derivam do confronto de premissas com a realidade estudada; e

- Rigorosa: faz tudo o que tiver ao seu alcance para minimizar erros.

\subsection{DEFINIÇÃO DO TIPO DE PESQUISA}

Para atingir o nível de comprometimento com base nos preceitos científicos, uma série de decisões metodológicas foi tomada, pertinente à forma e ao escopo do trabalho. A Figura 14, a seguir, apresenta o fluxograma dos principais questionamentos do autor que culminaram na decisão de uma abordagem específica, responsável pelo encaminhamento dos procedimentos metodológicos em cada uma das fases da dissertação.

O problema de pesquisa emergiu de determinadas condições relatadas na APRESENTAÇÃO, no Capítulo 1. INTRODUÇÃO e no Capítulo 2. CONTEXTUALIZAÇÃO DO MERCADO E DA INDÚSTRIA DE JOGOS DIGITAIS, que contemplou a experiência do autor e apresentou o contexto e as características gerais do mercado. O problema de pesquisa em questão, "Como micro e pequenas empresas desenvolvedoras brasileiras de jogos digitais conduzem sua gestão de marketing?", derivou de uma seleção de possíveis problemas, avaliados com base nos critérios elencados por Walliman (2015) tendo como características cruciais: ser significativo, delineável, acessível e passível de conclusões e aprendizados. 
Figura 14 - Fluxograma das principais decisões metodológicas da dissertação

\section{A. Contexto:}

Experiência do autor + Tendências + Situação do mercado

NÃO

Desse contexto emerge um problema que seja: significativo, delineável, acessível e passível de conclusões e aprendizados? (WALLIMAN, 2015) SIM

\section{B. Problema:}

Como micro e pequenas empresas brasileiras de

jogos digitais conduzem sua gestão de

marketing?

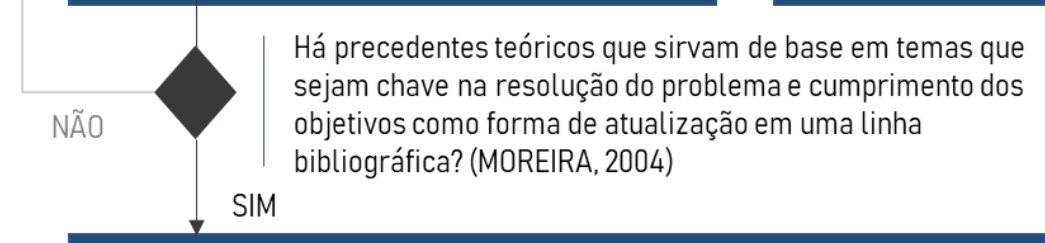

\section{Referencial teórico:}

Revisão de literatura que contempla conceitos associados ao marketing e

às indústrias criativas, em uma lógica de afunilamento que se encerra em

marketing em micro e pequenas empresas de jogos digitais.

Há hipóteses bem delimitadas, elementos bem definidos, modelos teóricos testados ou pressuposições plausíveis de causa e efeito? (SREEJESH, MOHAPATRA e ANUSREE, 2013)

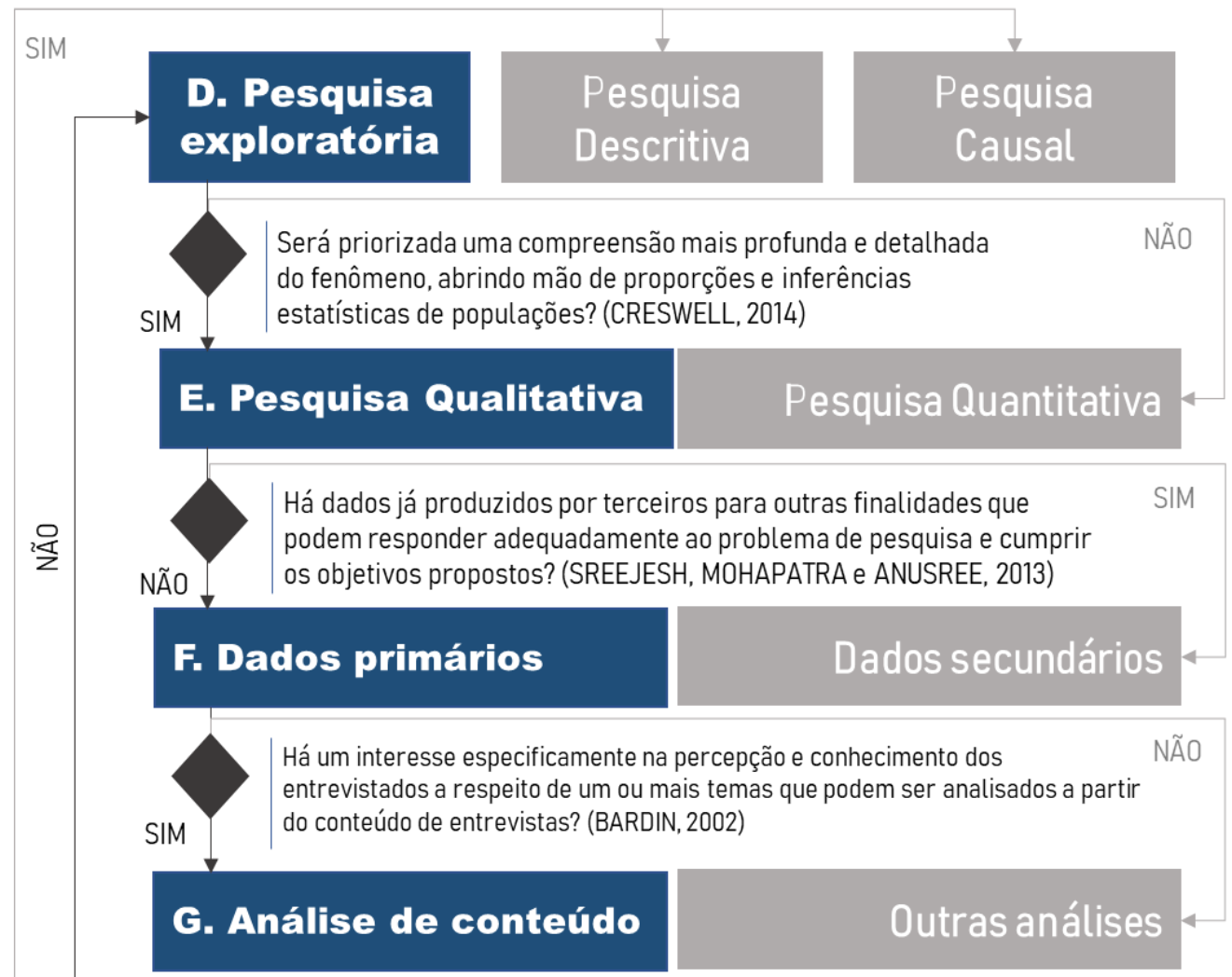

A partir dessas decisões, realizou-se uma análise temática do conteúdo de entrevistas com profissionais de micro e pequenas empresas brasileiras desenvolvedoras de jogos digitais, com foco em temas-chave avaliados qualitativamente, mas também lançando mão de técnicas sistemáticas que envolvem também abordagens quantitativas (BARDIN, 2002).

Fonte: Elaborada pelo autor, com base na Matriz de Amarração de Mazzon (1978; 2018) e nos trabalhos de Bardin (2011), Creswell (2014), Moreira (2004), Sreejesh, Mohapatra e Anusree (2013) e Walliman (2015). 
A resolução do problema, por sua vez, partiu da busca de trabalhos científicos direta ou indiretamente relacionados, que formariam o referencial teórico utilizando-se a classificação de propósito, abrangência, função e abordagem (MOREIRA, 2004) especificados anteriormente.

O referencial teórico trouxe os principais conceitos de gestão de marketing, gestão de marketing digital e gestão de marketing nas indústrias criativas e suas interseções, formando uma base sólida para a análise do problema de pesquisa em questão, mas não obtendo a resposta direta com modelos conceituais consolidados, hipóteses delineadas ou desafios de marketing elencados de forma categórica e exaustiva em relação às empresas estudadas, exigindo para isso a abordagem de uma pesquisa exploratória. Segundo Sreejesh, Mohapatra e Anusree (2013), a condução de um estudo exploratório justifica-se, sobretudo, em função de 3 questões: para analisar uma situação-problema; para avaliar alternativas; e para descobrir novas ideias.

Essa pesquisa pode, portanto, ser classificada em última análise como sendo uma "pesquisa de identificação de problemas" (MALHOTRA, 2006, p. 37), pois seu objetivo principal foi "elencar, descrever e qualificar grandes desafios que as micro e pequenas empresas desenvolvedoras brasileiras de jogos digitais precisam superar para melhorar sua gestão de marketing".

Diante da situação-problema proposta e do objetivo principal estabelecido, chegou-se à conclusão de que no presente processo de pesquisa:

- houve uma grande dependência do pesquisador como instrumento-chave da coleta de dados;

- houve a necessidade de raciocínio complexo que transitou entre o indutivo e o dedutivo;

- o foco esteve nas perspectivas dos participantes, os significados atribuídos ao contexto e em suas múltiplas visões subjetivas;

- a atuação dos participantes sensibilizou e foi determinante por estar situada dentro de um contexto muito específico;

- tratou-se de um projeto emergente e não de algo rigidamente pré-configurado;

- a análise dos resultados foi reflexiva e interpretativa, ou seja, esteve muito atrelada ao histórico e ao perfil do pesquisador; e

- não pretendeu extrapolar estatisticamente padrões de comportamento e de pensamento da amostra estudada.

Todos os itens elencados acima referem-se às principais características de uma pesquisa qualitativa, em oposição à pesquisa quantitativa (CRESWELL, 2014). Assim, a partir dessa concepção exploratória qualitativa, iniciou-se a busca por dados secundários como publicações 
governamentais, relatórios de mercado, livros, periódicos e outros documentos que serviram de base para melhor compreensão do contexto, delimitação do problema de pesquisa e elaboração do referencial teórico. No entanto, esse material não foi suficiente para atingir os objetivos propostos, exigindo a busca por dados primários (SREEJESH; MOHAPATRA; ANUSREE, 2013).

O principal interesse analítico desses dados está em seu conteúdo, na gestão das atividades de marketing executadas pelas empresas, na importância e no significado atribuído pelos potenciais entrevistados, em seus principais incômodos e problemas enfrentados diariamente. Essa perspectiva analítica está inserida no escopo da análise de conteúdo descrita por Bardin (2011), melhor delimitada e detalhada nas próximas seções.

As decisões tomadas a partir da situação-problema proposta culminaram, portanto, em uma pesquisa de caráter exploratório, por meio de uma abordagem qualitativa que utiliza dados primários, analisados por técnicas de análise de conteúdo.

\subsection{CRITÉRIOS DE SELEÇÃO E TAMANHO DA AMOSTRA}

Uma vez que a abordagem de pesquisa foi definida como exploratória e qualitativa, não houve, a priori, necessidade de coletar dados de todas as empresas ou de selecionar uma amostra probabilística que fosse estatisticamente replicável para toda a população (estimada em 505 desenvolvedoras). Foram priorizadas, portanto, a profundidade e a busca de novas possibilidades no lugar da padronização e da inferência estatística. Mesmo assim, em busca da máxima correspondência com a realidade brasileira retratada no Capítulo 2 . CONTEXTUALIZAÇÃO DO MERCADO E DA INDÚSTRIA, estabeleceu-se que seriam priorizadas as empresas desenvolvedoras que tivessem as características mencionadas a seguir, de acordo com a estratégia amostral por julgamento e não somente por uma orientação por conveniência (MARSHALL, 1996):

- Primeira sede deveria ter sido fundada no Brasil;

- Deveria ser Micro ou Pequena Empresa;

- Número de colaboradores deveria ser inferior ou igual a 15;

- Parte da produção deveria ser de jogos de entretenimento próprios ou terceirizados;

- Parte da produção deveria ser de jogos mobile ou web, preferencialmente casuais.

Dado que as unidades de medição (MALHOTRA, 2006, p. 135) que compõem a amostra são as micro e pequenas empresas desenvolvedoras de jogos digitais, houve 
necessidade de definir quais seriam as pessoas investigadas pertencentes a essas empresas. Pelo escopo e características da pesquisa, concluiu-se que deveriam ser aquelas capazes de representar e de falar em nome da instituição em termos de atividades de gestão de marketing que a empresa pode ou não praticar.

Um primeiro pensamento foi o de elencar gestores e líderes de áreas de marketing pertencentes às empresas. Considerando-se que se tratava de empresas com poucos recursos financeiros, humanos e técnicos, era razoável assumir que a chance de se encontrar um departamento ou uma pequena equipe de marketing dentro de tais empresas seria muito pequena.

Os dados do Segundo Censo das Empresas Brasileiras de Jogos Digitais (MINC, 2018) também apontam que a proporção de sócios nas áreas administrativas, financeiras, de marketing e de vendas tende a ser maior do que nas áreas de programação e de desenvolvimento por questão de diluição de risco, por serem tarefas mais difíceis de serem delegadas e gerenciadas (entre $44 \%$ e $67 \%$ ).

Também foi possível assumir que, dado o tamanho e a incipiência do negócio, os fundadores e os sócios das empresas tinham uma tendência à execução de tarefas de múltiplas áreas, mesmo que isso não fizesse parte do plano original. Além disso, sua proximidade com as operações e com o dia a dia dos colaboradores poderia ser maior do que em empresas de maiores portes.

Sendo assim, para a realização das entrevistas, optou-se pela priorização de sócios, sócios-diretores, sócio fundadores, Chief Executive Officers (CEOs) e correlatos, mas também deixando aberta a possibilidade de se entrevistar gestores de áreas de marketing, caso a empresa os possuísse.

Para cada empresa escolhida, que cumprisse os critérios pré-definidos, foi escalado 1 (um) representante. Mas, caso os dados coletados fossem insuficientes, ou a pessoa não se mostrasse capaz de representar a empresa ao abordar o assunto, não foi descartada a possibilidade de se entrevistar mais de uma pessoa da mesma empresa.

A quantidade de tomadores de decisão entrevistados foi norteada pelo conceito de saturação teórica, que levou em consideração o esgotamento de novos temas, fatos e discussões trazidas a cada entrevista realizada, utilizando os passos procedimentais de Fontanella et al. (2011), a saber:

- Disponibilizar os registros de dados brutos;

- "Imergir" em cada registro;

- Compilar análises individuais; 
- Reunir os temas ou os tipos de enunciados para cada nova categoria;

- Codificar ou nominar os dados;

- Alocar em uma tabela os temas e os tipos de enunciados;

- Constatar a saturação teórica pela recorrência de temas ou pela ausência de novos temas tratados;

- Visualizar a saturação (resumir os dados de forma que todos os temas sejam vistos como saturados ou não).

Foram realizadas 12 (doze) entrevistas no total, sendo 10 (dez) com representantes de empresas aderentes aos critérios definidos a priori, visando a constatar a saturação teórica das mesmas, e foram adicionadas 2 (duas) empresas de maior porte, como base de comparação para análise. A seção 4.3 a seguir apresenta o instrumento de pesquisa utilizado, que ditou o ritmo de tais entrevistas.

\subsection{INSTRUMENTO DE PESQUISA}

Como se trata de uma abordagem qualitativa, o instrumento de pesquisa não poderia ter uma estrutura inflexível, com questões e alternativas definidas e uma ordem de questionamentos inalterada. Por outro lado, também não seria produtivo conduzir uma entrevista totalmente desestruturada, sem guiar minimamente o participante a discorrer sobre temas e situações previamente definidos por serem os mais importantes para a resolução do problema de pesquisa (FRASER; GONDIM, 2004).

Optou-se, então, por um roteiro de pesquisa semiestruturado, a fim de nortear a entrevista, fazendo com que o pesquisador tivesse uma postura aberta no processo, interagindo com o entrevistado, mas não o restringindo a questões pré-estabelecidas. Para não desviar o foco da discussão, o instrumento criado contou com tópicos relacionados com a prática de marketing, sem impedir o aprofundamento de outros aspectos que pudessem ser relevantes aos objetivos delimitados (FRASER; GONDIM, 2004).

A seguir, serão descritas as bases teóricas da montagem do roteiro, sua estrutura temática e os pontos de exploração. 


\subsubsection{Base Teórica do Roteiro}

Segundo Fraser (2004), um bom roteiro deve ser precedido de uma revisão crítica da literatura, de modo que os temas a serem abordados, mesmo que de forma semiestruturada, estejam mais alinhados com o desenvolvimento científico consolidado da área e menos com uma visão parcial, seletiva ou enviesada do pesquisador.

Mesmo assim, há necessidade de se fazer escolhas, levando-se em consideração o contexto estudado, de modo a habilitar o pesquisador a julgar o que pode responder melhor ao problema de pesquisa. Daí emerge o termo "revisão crítica".

Seguindo esse preceito, o referencial teórico descrito anteriormente, obtido a partir dos achados de Moreira (2004), e que leva em consideração seus propósitos, abrangência, função e abordagem, serviu como ponto de partida para a elaboração do roteiro, do qual foi possível extrair o principal tema abordado: a condução da gestão de marketing em micro e pequenas empresas brasileiras desenvolvedoras de jogos digitais, que fazem parte do ramo das Indústrias Criativas. Esse tema principal exigiu explorar certos aspectos de marketing praticados ou não por essas empresas, denominados subtemas e outros temas mais abrangentes classificados como temas transversais.

O Quadro 1, na página seguinte, mostra os temas transversais e os principais subtemas de marketing elencados para formar a base teórica do roteiro. A relação foi elaborada de modo a contemplar os principais aspectos sob o ponto de vista da gestão de marketing, sem beirar a superficialidade, mas também sem ser altamente específico a ponto de limitar a exploração das entrevistas.

Os temas transversais são aqueles capazes de se relacionar com todos os subtemas elencados, como o marketing digital. Levando-se em consideração a definição da AMA (2020), o marketing digital é a aplicação do marketing tradicional em ambientes e ferramentas digitais. Sendo assim, o relacionamento com o cliente, por exemplo, pode ser feito a partir de sistemas de Customer Relationship Management (CRM) e de chat bots (atendimento automático via algoritmos), enquanto a distribuição do jogo pode ser feita por uma loja online que disponibiliza o download do arquivo do jogo comprado. Outros temas como processos e pessoas, marca e posicionamento, micro e macro ambientes e marketing nas Indústrias Criativas também possuem essas características de transversalidade. 
Quadro 1 - Base teórica do roteiro de pesquisa

\begin{tabular}{|c|c|c|}
\hline \multicolumn{3}{|c|}{ Tema Principal: Gestão de Marketing } \\
\hline $\begin{array}{l}\text { Temas } \\
\text { transversais }\end{array}$ & Subtemas & Principais autores \\
\hline \multirow{8}{*}{ 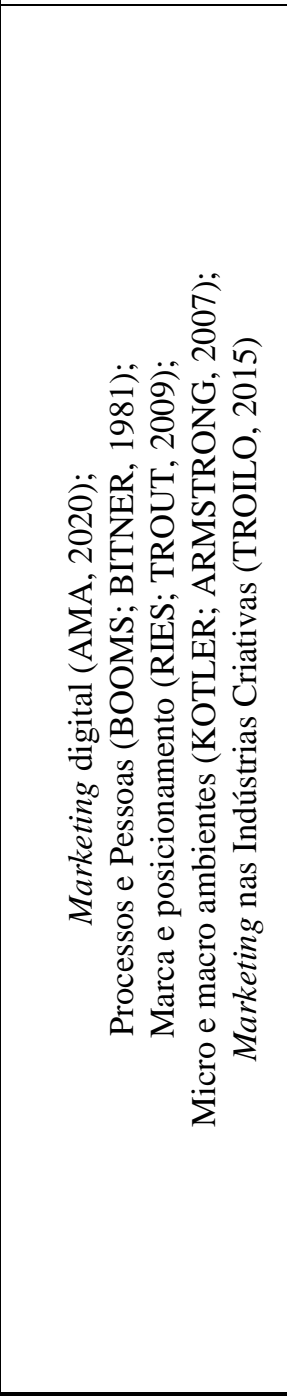 } & $\begin{array}{l}\text { Estratégia de marketing: } \\
\text { planejamento e visão }\end{array}$ & $\begin{array}{l}\text { (KOTLER; ARMSTRONG, 2007) } \\
\text { (VARADARAJAN, 2010) } \\
\text { (SEO, 2013) } \\
\text { (WALLER, 2015) }\end{array}$ \\
\hline & $\begin{array}{l}\text { Mercado: concorrência, segmentos } \\
\text { e público-alvo }\end{array}$ & \begin{tabular}{|l|} 
(SMITH, 1956) \\
(KOTLER, 1967) \\
(KOTLER; KELLER, 2006) \\
(KOTLER; ARMSTRONG, 2007) \\
(RIES; TROUT, 2009) \\
\end{tabular} \\
\hline & Relacionamento com clientes & $\begin{array}{l}\text { (REINARTZ; KRAFFT; HOYER, 2004) } \\
\text { (FROW; PAYNE, 2009) }\end{array}$ \\
\hline & Produto: características e funções & \begin{tabular}{|l} 
(BOOMS; BITNER, 1981) \\
(HENNIG-THURAU et al., 2006) \\
(KOTLER; ARMSTRONG, 2007)
\end{tabular} \\
\hline & $\begin{array}{l}\text { Preço: valor, formas de } \\
\text { monetização }\end{array}$ & $\begin{array}{l}\text { (SHETH; USLAY, 2007) } \\
\text { (KOTLER; ARMSTRONG, 2007) } \\
\text { (CWALINA; FALKOWSKI; NEWMAN, } \\
\text { 2011) } \\
\text { (NAGLE; HOGAN; ZALE, 2016) } \\
\end{array}$ \\
\hline & Praça: formas de distribuição & $\begin{array}{l}\text { (CONVERSE; JONES } 51,1948 \text { apud } \\
\text { BRUNSWICK, 2014) } \\
\text { (HOLLOWAY; HANCOCK, } 1968 \text { apud } \\
\text { BRUNSWICK, 2014) } \\
\text { (KOTLER; ARMSTRONG, 2007) } \\
\end{array}$ \\
\hline & $\begin{array}{l}\text { Promoção: publicidade e relações } \\
\text { públicas }\end{array}$ & \begin{tabular}{|l|} 
(GOMES, 2001) \\
(KOTLER; KELLER, 2006) \\
(ZACKARIASSON; WILSON, 2012) \\
(ALAIMO; KALLINIKOS, 2018) \\
\end{tabular} \\
\hline & $\begin{array}{l}\text { Inteligência de marketing: } \\
\text { pesquisa, ciência de dados e } \\
\text { análises }\end{array}$ & \begin{tabular}{|l} 
(KOTLER; KELLER, 2006) \\
(MALHOTRA, 2006) \\
(DAVENPORT; PATIL, 2012) \\
\end{tabular} \\
\hline
\end{tabular}

Fonte: Elaborado pelo autor.

O subtema estratégia de marketing, por exemplo, é, por natureza, altamente abrangente, mas sua abordagem pretendeu investigar como o entrevistado planejava as atividades de marketing e qual o seu ponto de vista - se as considerava importante (ou não), se as priorizava (ou não), se as negligenciava (ou não) etc. Por outro lado, atividades de promoção poderiam partir de atividades mais básicas, como a comunicação boca a boca até atividades mais

\footnotetext{
${ }^{51}$ CONVERSE, P. D.; JONES, F. M. Introduction to marketing. New York: Prentice-Hall, Inc, 1948.
} 
complexas, como a publicidade programática, que exigiriam maior tolerância e flexibilidade no instrumento de pesquisa.

Para cada tema transversal e subtema, o Quadro 1 relaciona os principais autores que sustentam a sua relevância e necessidade, os quais são elencados em ordem cronológica, de acordo com a data de publicação. No entanto, há autores e outras fontes que não foram mencionadas no Quadro 1, mas que constam no Capítulo 3. REFERENCIAL TEÓRICO para melhor detalhamento ou para fornecer outras perspectivas a respeito dos subtemas e dos temas transversais.

A partir dessa base teórica, foi necessário empreender uma busca por trabalhos que já tivessem mensurado aspectos e atividades de marketing (ou de gestão) em empresas com características similares (micro e pequenas empresas de Indústrias Criativas, digitais etc.). Isso foi necessário para evitar uma das principais fontes de erro de uma pesquisa: o de medição do pesquisador descrito por Malhotra (2006, p. 111), que supõe que respostas adequadas surgem de perguntas inadequadas ou mal formuladas.

Depois de tentativas frustradas de buscas em bases de dados que combinavam certos termos (como "marketing”, "desafios" e "formas de mensuração"), chegou-se à conclusão de que seria necessário realizar uma busca mais aprofundada por tais trabalhos na literatura. Ainda que o objetivo não tivesse sido esgotar ou fazer uma leitura completa e sistemática de um campo de estudo, a presente revisão procurou reduzir de forma racional e estruturada "uma grande quantidade de informações disponíveis a pequenas e digeríveis peças de informação" (MULROW, 1994, p. 597, tradução nossa).

A partir de algumas pesquisas de caráter exploratório, chegou-se à conclusão de que o termo chave com bom potencial de retornar resultados aderentes seria "maturity model" ou "modelo de maturidade", pois geralmente está associado a instrumentos de avaliação de aspectos empresariais como gestão de projetos (CRAWFORD, 2006), gestão de riscos empresariais (HILLSON, 1997), gestão de processos (ROSEMANN; BRUIN, 2005) ou terceirização de serviços de tecnologia da informação (GOTTSCHALK; SOLLI-SAETHER, 2006), podendo ser também aderente à gestão de marketing.

Foram utilizadas as bases de dados EBSCOhost, Emerald Insight, SciELO e Google Scholar - com buscas empreendidas com termos em inglês e seus equivalentes em português. Também foram utilizados periódicos especializados, como o Journal of Marketing, o Journal of Marketing Research e o Marketing Science. A busca foi realizada entre os dias 03 e 19 de fevereiro de 2020. A Figura 15, a seguir, apresenta os termos-chave utilizados para a busca de 
trabalhos de mensuração no contexto da pesquisa, combinados com o termo principal estabelecido.

Figura 15 - Termos-chave de busca para trabalhos de base para o instrumento ${ }^{52}$

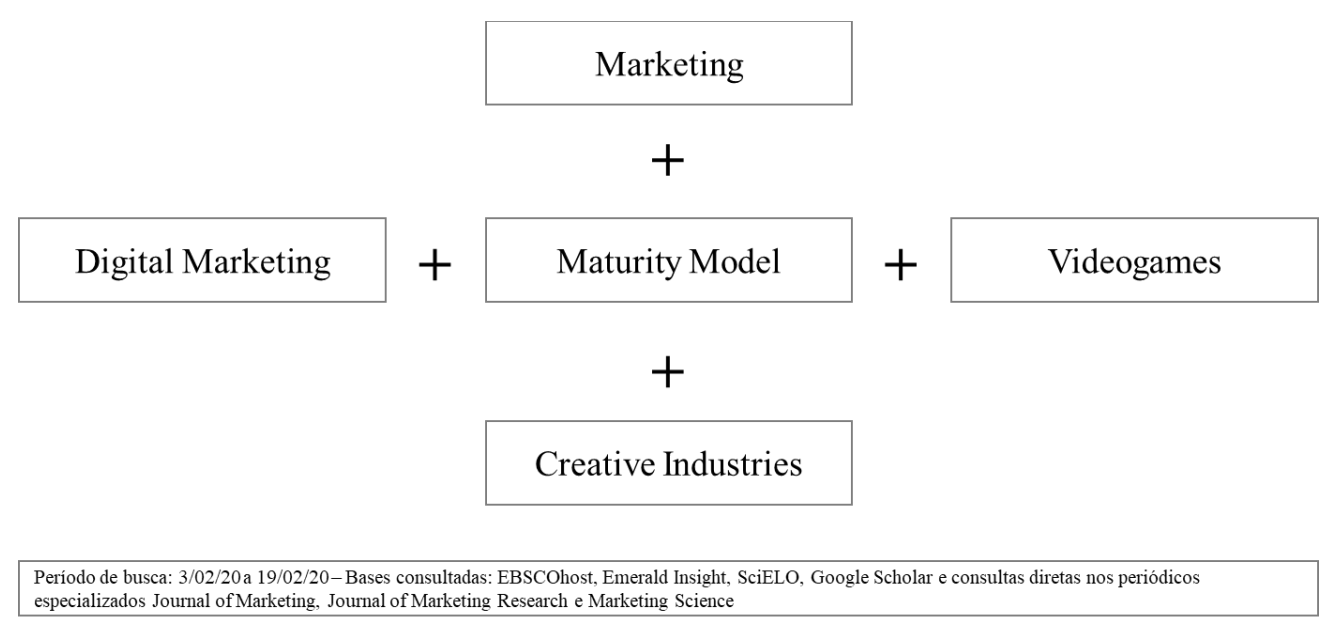

Fonte: Elaborada pelo autor.

O Quadro 2, a seguir, apresenta os procedimentos de busca e de filtragem dos trabalhos que resultaram na escolha de 5 artigos de base como guias de mensuração para a confecção do roteiro de entrevista.

Quadro 2 - Procedimentos de busca e de filtragem dos trabalhos

\begin{tabular}{|l|c|}
\hline \multicolumn{1}{|c|}{ Procedimentos } & $\begin{array}{c}\text { Resultados } \\
\text { (número de } \\
\text { trabalhos) }\end{array}$ \\
\hline $\begin{array}{l}\text { 1. Uso de termos-chave associados à "maturity model" nas bases de dados } \\
\text { selecionadas. }\end{array}$ & 21.260 \\
\hline $\begin{array}{l}\text { 2. Filtros de recência e relevância para ordenação dos 30 primeiros trabalhos } \\
\text { (dado o prazo estabelecido de campo) para cada termo e base combinados (30 } \\
\text { primeiros x 4 termos x 7 bases). }\end{array}$ & 840 \\
\hline $\begin{array}{l}\text { 3. Avaliação do título com exclusão de trabalhos que não estivessem } \\
\text { diretamente relacionados com os instrumentos de avaliação no contexto } \\
\text { pesquisado. }\end{array}$ & 78 \\
\hline $\begin{array}{l}\text { 4. Avaliação do resumo com exclusão de trabalhos que não estivessem } \\
\text { diretamente relacionados com os instrumentos de avaliação no contexto } \\
\text { pesquisado. }\end{array}$ & 32 \\
\hline $\begin{array}{l}\text { 5. Ordenação de 32 trabalhos a partir da leitura do conteúdo e da atribuição de } \\
\text { uma nota de 1 a 5, sendo 1-pouco aderente e 5-muito aderente. Foram } \\
\text { selecionados os trabalhos com nota 5. }\end{array}$ & 5 \\
\hline
\end{tabular}

Fonte: Elaborado pelo autor.

\footnotetext{
52 Os termos equivalentes em língua portuguesa também foram consultados: Modelo de Maturidade, Indústrias Criativas e Marketing Digital. Ressalta-se que 'Marketing' e 'Videogames' não foram traduzidos.
} 
As referências selecionadas foram: Aleem, Capretz e Ahmed (2016), Alford e Page (2015), Abbasi, Vassilopoulou, Stergioulas (2016), Andriani et al. (2018) e Chaffey (2010). Esses trabalhos contam com frameworks de avaliação, roteiros ou formulários realizados para avaliar as características ou os níveis de maturidade referentes a aspectos de negócio da indústria ou mais especificamente de marketing e de marketing digital. Algumas dimensões de mensuração encontradas foram: desenvolvimento de relacionamento com o consumidor, gestão de canais digitais, integração de canais, governança de marketing, gestão de marketing e tecnologias de marketing em pequenos negócios, as quais foram adaptadas e mescladas aos temas elencados para a elaboração do roteiro.

\subsubsection{Estrutura do Roteiro}

Após o pré-teste realizado com o primeiro entrevistado, foi necessário alterar a ordem do bloco de Relacionamento com os clientes, substituindo-o pelo bloco de Produto, assim como flexibilizar a ordem das questões intrablocos em função da narrativa do entrevistado. Mesmo assim, os dados desta primeira entrevista puderam ser aproveitados na íntegra por não representarem mudanças estruturais em relação às demais. A versão final do roteiro com indicação das mudanças após a primeira entrevista encontra-se no APÊNDICE 1.

Com base nos temas e nos instrumentos de pesquisa encontrados na literatura, o roteiro, em sua forma semiestruturada, resumiu-se a alguns blocos principais, com os objetivos e pontos de exploração descritos a seguir:

Bloco 1 - Introdução: visou a apresentar o entrevistador, o objetivo geral da entrevista e o tempo de duração da mesma.

Bloco 2 - Apresentação do entrevistado, trajetória profissional e características da empresa: visou a deixar o entrevistado à vontade e aberto aos questionamentos posteriores, relatando sua trajetória profissional e as características da empresa, ao mesmo tempo em que fornecia, de forma espontânea ou estimulada, algumas informações referentes ao cargo, departamento, tempo de empresa, quantidade de países em que a empresa atua, tipos de jogos desenvolvidos, número de colaboradores, parceiros etc. 
Bloco 3 - Principais atribuições e desafios: visou a apresentar o escopo de atuação do entrevistado, de forma geral, incluindo também as atividades sem relação direta com a gestão de marketing, evitando vieses de confirmação, a saber:

- Atividades realizadas no dia a dia;

- Problemas gerais enfrentados;

- Objetivos e metas de curto, médio e longo prazos da empresa;

- Pessoas responsáveis pelas definições desses objetivos;

- Recursos disponíveis para atingimento das metas e dos objetivos;

- Responsabilidades e desafios.

Bloco 4 - Estratégia de marketing: visou a demonstrar se e como a empresa elaborava sua estratégia de marketing:

- Visão da empresa sobre ações de marketing;

- Forma como a empresa planejava, executava e acompanhava atividades de marketing;

- Forma como os ingredientes do mix de marketing eram geridos;

- Forma como a empresa posicionava-se frente à concorrência e como gerenciava sua marca (se fosse o caso).

Bloco 5 - Mercado: concorrência, segmentos e público-alvo: visou a compreender se e como o público potencial era definido e gerido para cada jogo lançado:

- Identificação e relação com a concorrência;

- Formas de contato e aproximação com potenciais públicos;

- Tipos de levantamentos ou pesquisas realizadas;

- Momentos-chave de produção em que decisões dessa esfera eram tomadas;

- Características sociodemográficas, psicográficas e comportamentais dos públicos.

Bloco 6 - Produto: visou a compreender o processo de desenvolvimento e as principais decisões tomadas para o lançamento e a gestão do jogo:

- Origens das ideias de um novo jogo: nível de estruturação do processo;

- Critérios de tomada de decisão para o respectivo lançamento;

- Procedimentos de testes para o mercado;

- Premissas de um bom jogo para satisfação do público-alvo;

- Processos para definição das atualizações; 
- Definição da empresa sobre o que significava lançar um jogo de sucesso.

Bloco 7 - Preço: visou a compreender como a empresa lidava com os aspectos financeiros do jogo, de que forma precificava e relacionava os custos com os retornos esperados do projeto:

- Decisões de investimentos e alocação de verbas;

- Fontes de recursos da empresa;

- Projeção de retorno sobre investimento;

- Modelos de monetização utilizados nos jogos;

- Formas e lógicas por trás dos modelos de monetização utilizados.

Bloco 8 - Praça: visou a entender as formas de distribuição dos jogos criados, os tipos de plataformas escolhidas e a abrangência de atuação (nacional ou internacional):

- Critérios para escolha de uma plataforma em detrimento de outra;

- Gestão dos canais de distribuição;

- Relacionamento entre as partes da cadeia de valor como as produtoras, varejistas e distribuidoras.

Bloco 9 - Promoção: visou a compreender o planejamento, a execução e o acompanhamento de campanhas e de outras formas de promoção dos jogos:

- Planejamento de mídia: periodicidade, recursos e métodos;

- Formas de divulgação nos ambientes online e offline;

- Uso de recursos de promoção pagos e gratuitos (ex.: relações públicas);

- Principais meios de comunicação utilizados;

- Premissas para elaboração de peças e de materiais de divulgação;

- Avaliação da performance das atividades de promoção.

Bloco 10 - Relacionamento com os clientes: visou a entender de que forma a empresa se relacionava com seus clientes.

- Principais ferramentas, meios ou recursos utilizados para se relacionar com jogadores da base (sistemas CRM, se fosse o caso);

- Processos de trabalho para responder a demandas, críticas ou solicitações dos jogadores;

- Relacionamento com a comunidade e fóruns. 
Bloco 11 - Inteligência de marketing: visou a entender a gestão de dados para transformação de inteligência em atividades de marketing:

- Principais fontes de dados da empresa;

- Formas de armazenamento e de organização dos dados;

- Tipos de análises realizadas com tais dados;

- Tipos de relatórios criados e desafios associados a seu uso;

- Indicadores de sucesso e de performance do jogo;

- Uso de dados gerados por comportamentos dentro do jogo;

- Nível de automatização do processo de coleta, tratamento e análise de dados.

Bloco 12 - Perspectivas para a empresa e para o mercado: visou a entender o ponto de vista do entrevistado em relação à forma como o mercado brasileiro iria evoluir e de que forma a empresa do entrevistado iria se encaixar nos cenários futuros, incluindo as perspectivas de marketing.

Bloco 13 - Dados adicionais e agradecimento: visou a indagar os entrevistados a responderem, de forma voluntária, sobre o nível de faturamento e/ou porte da empresa para fins de descrição. Essa informação, mesmo sendo um critério de priorização da seleção, foi solicitada ao final da entrevista para evitar resistência e desconfiança por parte dos entrevistados sobre as principais questões do roteiro.

Os assuntos transversais como marketing digital, pessoas e processos, marca e posicionamento, micro e macro ambientes e especificidades de marketing nesse tipo de indústria foram estimulados entre os pontos de exploração descritos ou quando a narrativa do entrevistado permitia ou quando mencionados espontaneamente pelo entrevistado.

\subsection{COLETA DE DADOS DE CAMPO}

A coleta de dados de campo pode se mostrar desafiadora pela existência de eventuais erros que possam comprometer a qualidade e a confiabilidade dos dados obtidos seja pela falta de resposta dos entrevistados selecionados, seja pela falha na composição e na seleção da amostra, seja pela forma de questionamento ou formato do roteiro (não extraindo as melhores 
respostas) ou mesmo por outros erros que não possam ser completamente eliminados, mas que devem ser necessariamente controlados (MALHOTRA, 2006).

Além disso, o período que contemplou a execução da primeira à última entrevista (de 27 de abril de 2020 a 7 de junho de 2020) coincidiu com a crise do Corona vírus, que já havia acumulado, somente no Brasil, naquele momento, 698.758 casos e 36.455 óbitos (MINISTÉRIO DA SAÚDE, 2020). Tal fato implicou medidas restritivas de circulação das pessoas em níveis e períodos diversos, determinados pelos governadores dos Estados, incentivando a adoção do home office (trabalho em casa), especialmente em setores com atividades que permitiam que os serviços fossem executados de forma digital ou a distância (MONTINI, 2020), como as empresas desenvolvedoras de jogos digitais. Essas circunstâncias exigiram que as entrevistas fossem realizadas a distância (via videochamadas online), com métodos de contato e abordagens especificados detalhadamente a seguir.

\subsubsection{Processo de Construção e Gestão do Mailing de Entrevistados}

Antes de realizar a primeira entrevista, foi feito o levantamento das empresas (mailing) que se enquadravam nas características pré-definidas pelo estudo e que possuíam dados e informações de contato de pessoas chave disponíveis para que pudessem ser abordadas. Esse trabalho teve início em 16 de março de 2020, cerca de quarenta dias antes da realização da primeira entrevista, ocorrida em 27 de abril de 2020, e seguiu em paralelo, na medida em que as demais entrevistas foram ocorrendo, para que os dados das empresas continuassem sendo atualizados.

Conforme estimativa apresentada anteriormente, o universo potencial de entrevistados é composto por aproximadamente 505 empresas ou pessoas jurídicas. Mesmo com problemas do setor de alta informalidade, mortalidade das empresas e dificuldade de abordagem de seus representantes apontados pelo Segundo Censo da Indústria Brasileira de Jogos Digitais (MINC, 2018), graças à junção das bases de dados fornecidas pelo Mapa da Indústria de Jogos no Brasil, da lista de associados da Associação Brasileira das Desenvolvedoras de Jogos Eletrônicos (ABRAGAMES) e da rede de contatos profissionais do autor foi possível localizar 386 delas, o que totalizou aproximadamente $76 \%$ do universo.

Após esse processo que envolveu a mesclagem e a eliminação de empresas duplicadas (que mudaram de nome ao longo do tempo, por exemplo), iniciou-se o trabalho de avaliação caso a caso daquelas que melhor se adequassem às características predominantes da Indústria Brasileira, tais como: desenvolvimento de jogos mobile, web e/ou de cunho mais casual, com 
menor necessidade de investimento; desenvolvimento de jogos de entretenimento próprios ou por encomenda de terceiros do tipo Advergames ou serious games; e dados em redes sociais como LinkedIn, sites próprios ou de terceiros, que pudessem fornecer informações a respeito do porte da empresa em termos do número de colaboradores ou de faturamento, de modo que fosse possível priorizar as micro e as pequenas empresas.

Esse trabalho de filtragem acabou eliminando 129 empresas da relação inicial (composta por 386 empresas, como mencionado anteriormente), restando, então, 257 empresas que, a princípio, poderiam representar adequadamente a maior parte das empresas do universo pesquisado. Optou-se, a princípio, pela seleção aleatória de $20 \%$ dos 257 potenciais entrevistados para busca detalhada de informações de contato a partir de sites, redes sociais ou indicações, pois a busca por detalhes de contato de $100 \%$ das empresas potenciais seria improdutiva e desnecessária face à baixa quantidade de respostas necessárias para o estudo. À medida que os contatos foram sendo realizados, foram surgindo indicações de outras empresas que não constavam no rol inicialmente elaborado (composto por 257 empresas).

Caso a primeira fase de abordagem não fosse suficiente para coletar as informações necessárias, haveria a possibilidade de execução de uma segunda $(+20 \%)$, terceira $(+20 \%)$, quarta $(+20 \%)$ ou quinta $(+20 \%)$ fases. No entanto, não houve tal necessidade.

Um banco de dados foi, então, criado com a listagem das empresas e enriquecido com dados de tomadores de decisão potencialmente aptos a realizarem a entrevista, como: seus números de telefone pessoais ou corporativos, e-mails, perfis de LinkedIn e outros canais de atendimento corporativos (chat, formulários de site, páginas de Facebook etc.). Tais dados foram obtidos a partir das seguintes fontes: rede profissional do autor (com a explícita anuência do potencial entrevistado), indicação dos próprios entrevistados no decorrer das entrevistas e/ou meios públicos de divulgação (site da empresa, página no Facebook ou LinkedIn ou outras formas oficiais de contato). A Figura 16, na página seguinte, apresenta o processo de seleção e de filtragem dos contatos até a obtenção do número final da amostra.

Ao final, foram realizadas 12 (doze) entrevistas, conforme previsto, sendo que 10 (dez) correspondiam ao perfil pré-determinado e duas adicionais, que serviram de parâmetros para comparações e outras análises adicionais. Esse processo, mesmo executado sob uma perspectiva exploratória e qualitativa, sem pretensões de inferência para toda a população, procurou o máximo possível de representatividade, por meio de critérios de seleção e de filtragem de empresas com as características mais marcantes das desenvolvedoras brasileiras de jogos digitais. 
Figura 16 - Processo de seleção e de filtragem das empresas do mailing

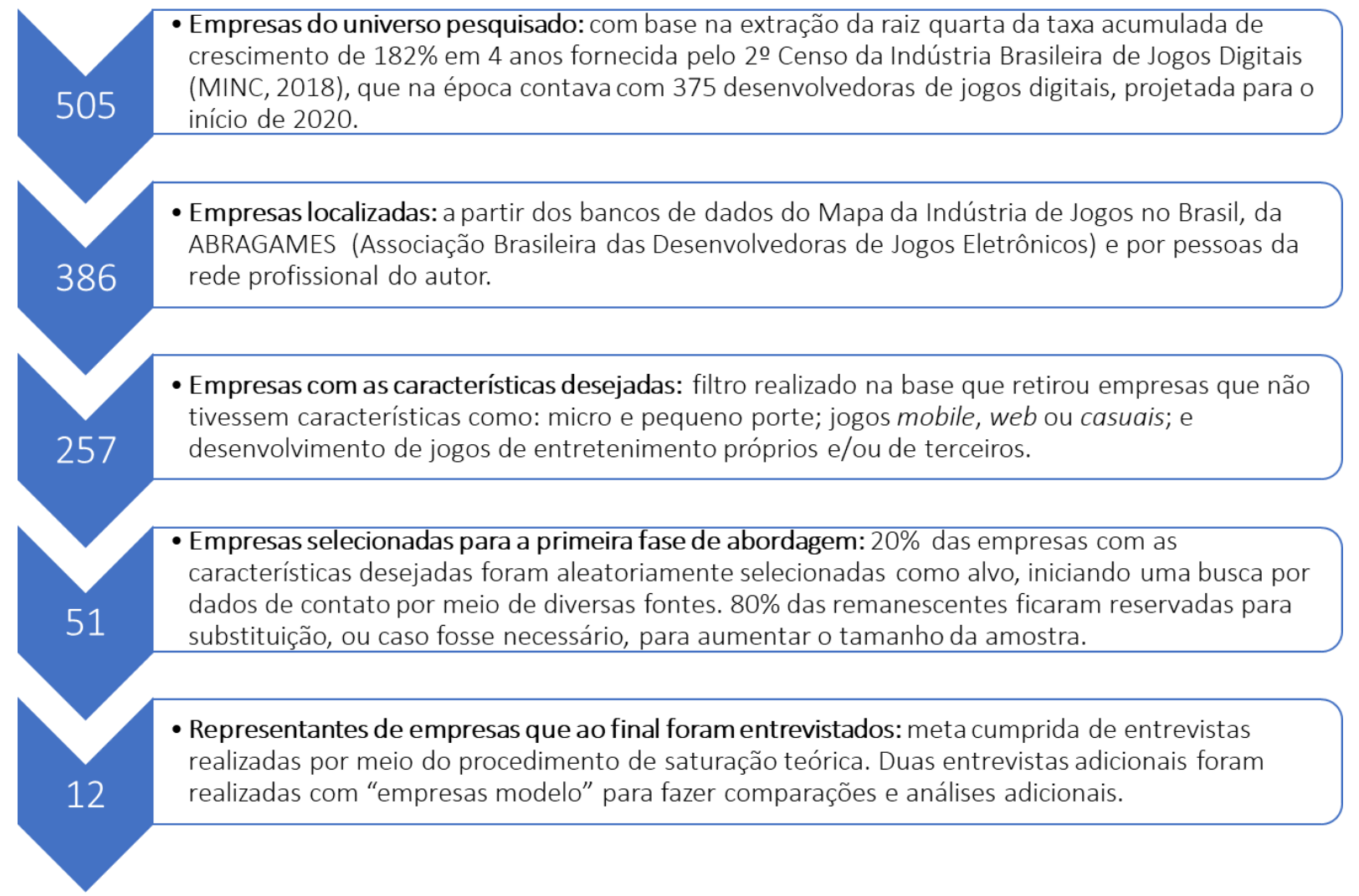

Fonte: Elaborada pelo autor.

\subsubsection{Abordagem dos Potenciais Entrevistados}

Os procedimentos de abordagem dos potenciais entrevistados tiveram início em 20 de abril de 2020. A primeira entrevista foi agendada e realizada em 27 de abril de 2020, com um tomador de decisão de uma das empresas selecionadas. Ao todo, para a realização das 12 (doze) entrevistas, foram necessárias 7 (sete) semanas de busca por informações de contato, envio de convites via diferentes meios de comunicação e organização de agendas. A última entrevista foi realizada em 7 de junho de 2020 .

Todos os procedimentos de abordagem foram guiados por princípios de boas práticas de trabalhos de campo, conforme relatados por Turner (2010), visando à redução de erros por falta de resposta, como recusas ou dificuldades de contato com entrevistados selecionados (MALHOTRA, 2006). A seguir, são elencadas as principais técnicas utilizadas para minimizar tais erros:

- Mensagem - elaboração de uma carta convite: uma Carta-base de Convite foi elaborada e assinada pelo autor e pela sua orientadora (APÊNDICE 2), com disponibilização dos 
contatos oficiais da Universidade de São Paulo para encorajar os tomadores de decisão a participarem da entrevista, com possíveis questões sensíveis e estratégicas de seu negócio. A mensagem foi adaptada para cada um dos meios de contato (e-mail, redes sociais, WhatsApp etc.), mas sempre com os seguintes pontos chave: identificação do autor e da orientadora, objetivo geral da entrevista, esclarecimento sobre a confidencialidade e a não divulgação individual dos dados, tempo previsto para realização da entrevista, incentivo de participação e solicitação de agendamento, caso o convite fosse aceito.

- Meios - priorização de meios de contato: os meios de contato utilizados para cada respondente não foram necessariamente os mesmos e muitas vezes um único potencial entrevistado possuía dois ou mais meios obtidos, os quais obedeceram a seguinte ordem de prioridade de acionamento, supondo a maximização da probabilidade de resposta: $1^{\circ}$ ) telefone ou WhatsApp pessoal; $2^{\circ}$ ) $e$-mail pessoal; $3^{\circ}$ ) LinkedIn InMail (que permite o envio de mensagens a contatos não adicionados); $4^{\circ}$ ) Telefone ou WhatsApp corporativo; $5^{\circ}$ ) E-mail corporativo; e $5^{\circ}$ ) Redes sociais corporativas (Facebook e LinkedIn). Todos os contatos foram obtidos por meios públicos de divulgação ou com a anuência do entrevistado.

- Contato - personalização: todos os contatos foram realizados de forma individual e personalizada, independentemente do meio utilizado. A forma de tratamento sempre foi nominal (pelo primeiro nome), seguida de um esclarecimento sobre a forma como o contato foi obtido (por exemplo: “consegui seu contato com 'Fulano(a)', da empresa ' $\mathrm{X}$ ' que trabalhou com você no Projeto ' $\mathrm{Y}$ '”). Não foram utilizadas formas impessoais de tratamento ou meios de comunicação massivos como ferramentas de e-mail marketing, pelo fato de a amostra necessária ser pequena e para garantir maior engajamento.

- Frequência - minimização da saturação da base: um sistema de acompanhamento de resposta aos convites foi criado com os seguintes critérios: ao enviar o convite pela primeira vez, aguardava-se uma semana pela resposta. Caso não houvesse retorno, um segundo contato era realizado, como forma de lembrete, valendo-se de outros meios de comunicação disponíveis. Novamente aguardava-se mais uma semana. Caso a empresa do participante fosse considerada de alta prioridade, em função das características 
previamente definidas, um terceiro e último convite era realizado. Esse longo espaço temporal para retorno do contato do entrevistado e limitação ao máximo de 3 (três) abordagens visou à minimização da saturação da base, que poderia se manifestar em forma de indisposição de entrevistados, que eventualmente poderiam estar genuinamente dispostos a responder.

- Recompensa - incentivo para participação: segundo Scherpenzeel e Toepoel (2012), incentivos são uma forma efetiva de se obter a anuência de entrevistados a participarem de estudos, pois há a sensação de que recursos essenciais, como o tempo, não estão sendo "mal investidos". Tendo isso em mente, foi oferecido a cada participante um relatório executivo com o resumo dos principais resultados do presente estudo, a ser enviado após a defesa da presente dissertação. Esse incentivo parte do pressuposto de que se trata de informações importantes sobre o mercado de atuação dos(as) entrevistados(as) e que podem de alguma forma auxiliá-los(as) na gestão de marketing de suas próprias empresas.

Com a implementação de tais procedimentos de abordagem, as entrevistas foram agendadas e realizadas, conforme descrito a seguir.

\subsubsection{Pré-teste e Execução das Entrevistas}

A primeira entrevista foi realizada em caráter de teste, de modo a possibilitar revisões que garantissem a qualidade do estudo (TURNER, 2010). Como mencionado no item 4.3 INSTRUMENTO DE PESQUISA, o questionário foi dividido em 13 Blocos. Algumas dúvidas do autor puderam, a partir de então, ser sanadas e ações foram tomadas para não prejudicar a continuidade do processo de abordagem e o agendamento das entrevistas posteriores, a saber:

Dúvida 1: Qual seria o tempo de duração necessário para abordar todos os tópicos elencados no roteiro semiestruturado?

O tempo estimado de duração tinha sido de 1 hora, no entanto, constatou-se que a entrevista de pré-teste durou 1 hora e 5 minutos. Portanto, para a execução das demais entrevistas, foi informado que o tempo necessário seria de aproximadamente 1 hora, com o compromisso de não ultrapassar 1 hora e meia. 
Dúvida 2: Como garantir o adequado registro das entrevistas com o mínimo possível de perda de informações fornecidas pelos respondentes?

Como as entrevistas seriam realizadas a distância, deveriam ser testadas ferramentas de videochamadas. A ferramenta utilizada na primeira entrevista foi o Google Meet ${ }^{53}$ e esta cumpriu com as expectativas iniciais, uma vez que possibilitou de forma mais intuitiva e adequada os recursos necessários, com uma conexão estável e maior possibilidade de armazenamento da gravação das entrevistas online ou em 'nuvem'54 (reduzindo consideravelmente os riscos de perda da gravação). Ainda assim, a ferramenta Zoom ${ }^{55}$ foi definida como substituta, em caso de falha da primeira (o que realmente ocorreu em uma das entrevistas). Durante a execução das entrevistas, o Samsung Voice Recorder ${ }^{56}$ (aplicativo de gravação de voz de alta qualidade para smartphones) foi utilizado para gravar as entrevistas em paralelo com o gravador de vídeo chamada, servindo de backup em caso de falhas na gravação de vídeo.

Dúvida 3: Como fazer perguntas sobre dados confidenciais ou sensíveis?

Com base na experiência da primeira entrevista, optou-se pela realização de perguntas sobre faturamento ou maiores detalhes sobre os projetos ao final, após terem sido discutidos todos os outros tópicos. Além disso, passou-se a reforçar, logo no início, que os propósitos eram estritamente acadêmicos, os dados eram confidenciais e seriam avaliados de forma agregada. Mesmo cientes de todos esses critérios, o entrevistado tinha liberdade para responder apenas as perguntas que quisesse.

Dúvida 4: Como informar que a entrevista estaria sendo gravada sem causar desconforto? Antes da realização das entrevistas, essa era uma das principais preocupações do autor, mas, na prática, representou para os entrevistados ser um procedimento padrão e previsível, não apresentando grande resistência ou negação, desde que as gravações não fossem publicizadas. Dúvida 5: Qual seria a sequência de temas mais adequada a ser obedecida em cada entrevista?

\footnotetext{
${ }^{53}$ Site oficial disponível em: https://meet.google.com/. Acesso em: 14 jun. 2020.

${ }^{54}$ Armazenamento em nuvem é uma tecnologia que permite guardar dados na Internet sem a necessidade de um aparelho físico ou dispositivo de memória dedicado para tal. Maiores informações disponíveis em: https://play.google.com/store/apps/details?id=com.sec.android.app.voicenote\&hl=en\&gl=US. Acesso em: 14 jun. 2020.

${ }^{55}$ Site oficial disponível em: https://zoom.us/. Acesso em: 14 jun. 2020.

${ }^{56}$ Disponível em: https://play.google.com/store/apps/details?id=com.sec.android.app.voicenote\&hl=en\&gl=US. Acesso em: 21 mar. 2021.
} 
A realização da primeira entrevista possibilitou descobrir que a ordem dos temas deveria ser flexibilizada individualmente em função de cada entrevistado, mantendo sempre que possível os limites de cada ponto de exploração e deixando-o à vontade para falar, evitando ao máximo interrupções e questionamentos sobre outros temas que supostamente deveriam ter sido abordados anteriormente. Somente o relacionamento com os clientes mostrou-se como uma temática convenientemente mais bem posicionada após a discussão sobre os 4Ps do Mix de Marketing de forma geral, o que refletiu na versão final do roteiro.

Com esses aprendizados adquiridos e com as dúvidas sanadas após a realização dessa entrevista pré-teste, as demais foram realizadas com pequenos ajustes e adaptações de acordo com cada situação. Essa entrevista piloto foi, então, incorporada ao conjunto de entrevistas analisadas por apresentar similaridade de nível de qualidade e riqueza de informações verificadas assim como as demais.

\subsection{CARACTERIZAÇÃO DA AMOSTRA}

Nesse contexto, a caracterização da amostra exigiu a devida separação entre duas unidades de medição (MALHOTRA, 2006, p. 135): as micro e pequenas empresas desenvolvedoras brasileiras de jogos digitais e seus representantes selecionados para realização das entrevistas em profundidade.

Uma empresa é um conjunto e o indivíduo é parte de tal conjunto. Mesmo que o indivíduo constitua uma grande parte da instituição por seu trabalho ou por sua posição (liderança ou representatividade legal), sua visão, seus pontos de vista e suas perspectivas podem, em maior ou menor medida, diferir da visão da própria empresa.

Com isso em mente, buscou-se o maior nível de representatividade possível das empresas por meio dos indivíduos entrevistados, mas a ciência dessa limitação traz a sobriedade necessária no ato de analisar a empresa em termos de gestão de marketing. A seguir, são apresentados o perfil das empresas e, em sequência, o perfil dos entrevistados, conservando a referência de identificação, por exemplo: Entrevistado 1 = entrevistado representante da Empresa 1. 


\subsubsection{Perfil das Empresas}

Das empresas analisadas (Quadro 3), 10 (dez) enquadram-se no porte prioritário de micro e pequenas empresas, com base na classificação do Banco Nacional de Desenvolvimento (BNDES, 2021). Microempresas: possuem receita operacional bruta anual inferior ou igual a $\mathrm{R} \$ 360$ mil; e pequenas empresas, receita entre $\mathrm{R} \$ 360$ mil e inferior ou igual a $\mathrm{R} \$ 4,8$ milhões. As empresas 3 (três) e 12 (doze) são de portes médio e grande, respectivamente. Por possuírem porte distinto do das demais empresas da amostra, elas foram classificadas como outliers, ou seja, o conteúdo também foi avaliado, mas de forma separada e independentemente do conteúdo das demais.

A maioria das empresas analisadas está sediada na Região Sudeste, mas há pelo menos uma empresa de cada uma das regiões do Brasil. As empresas possuem no mínimo 3 (três) anos de existência, sendo as mais recentes fundadas em 2017 e as mais antigas, em 2011 (com aproximadamente 10 anos de idade). O número de colaboradores das micro e pequenas empresas está em conformidade com o padrão da indústria nacional, com exceção da média e da grande empresa, que contam com aproximadamente 50 e 760 colaboradores respectivamente (Quadro 3).

Quadro 3 - Perfil geral das empresas

\begin{tabular}{|c|c|c|c|c|c|}
\hline Empresa & Porte & Região & Fundação & Colaboradores & Sócios \\
\hline 1 & Micro & Nordeste & 2016 & 11 & 3 \\
\hline 2 & Pequena & C. Oeste & 2011 & 7 & 2 \\
\hline $3 *$ & Média & Norte & 2015 & 50 & 1 \\
\hline 4 & Micro & Sudeste & 2016 & 14 & 3 \\
\hline 5 & Micro & Sudeste & 2014 & 3 & 2 \\
\hline 6 & Pequena & Sudeste & 2016 & 18 & 4 \\
\hline 7 & Pequena & Sudeste & 2017 & 8 & 4 \\
\hline 8 & Pequena & Sudeste & 2016 & 4 & 1 \\
\hline 9 & Micro & Sul & 2017 & 12 & 2 \\
\hline 10 & Micro & Sudeste & 2014 & 5 & 5 \\
\hline 11 & Pequena & Sudeste & 2013 & 2 & 2 \\
\hline $12 *$ & Grande & Sudeste & 2011 & 760 & 2 \\
\hline
\end{tabular}

* Empresas consideradas outliers em função de seu porte.

Fonte: Elaborada pelo autor, com base nos dados da pesquisa. 
Outro reflexo importante da realidade nacional é o número de sócios, geralmente são 2 ou mais (Quadro 3). As entrevistas revelaram que isso ocorre por conta de uma divisão básica de partida: um deles possui conhecimento técnico (programação e desenvolvimento de jogos) e o outro possui conhecimento administrativo (para cuidar das questões financeiras, burocráticas e de outras áreas de negócio).

\subsubsection{Perfil dos Entrevistados}

Todos os entrevistados possuem cargos que demandam funções de liderança dentro da empresa - os chamados C-levels, que, em sua maioria, são os principais tomadores de decisão de suas organizações (Chief Executive Offices - CEOs). Além disso, 10 (dez) dentre os 12 (doze) entrevistados são sócio fundadores dessas empresas, indicando um acúmulo de histórico, experiência e visão valiosos para a aquisição de dados para a pesquisa. Os 2 (dois) entrevistados denominados "funcionários" são também parte das empresas consideradas outliers por terem uma infraestrutura muito maior ou mais evoluída do que as demais, conforme será explicado posteriormente. O Quadro 4 exibe o perfil de todos os entrevistados.

Quadro 4 - Perfil geral dos entrevistados

\begin{tabular}{|c|c|c|c|c|c|c|c|}
\hline Ent. & $\begin{array}{l}\text { Tipo de } \\
\text { colaborador. }\end{array}$ & Cargo/Função & Idade & $\begin{array}{c}\text { Exp. } \\
\text { na área } \\
\text { (em anos) } \\
\end{array}$ & \begin{tabular}{|c|} 
Exp. \\
outro(s) \\
setor(es) \\
\end{tabular} & $\begin{array}{c}\text { Exp. } \\
\text { empreendedora } \\
\text { anterior }\end{array}$ & $\begin{array}{c}\text { Ocupação } \\
\text { paralela }\end{array}$ \\
\hline 1 & Sócio fundador & Presidente/CEO & 33 & 8 & Sim & Sim & Não \\
\hline 2 & Sócio fundador & Presidente/CEO & 32 & 8 & Sim & Sim & Sim \\
\hline 3 & Funcionário & Produtor Executivo & 32 & 8 & Sim & Não & Não \\
\hline 4 & Sócio fundador & Diretor de Produtos & 40 & 5 & Sim & Sim & Não \\
\hline 5 & Sócio fundador & $\begin{array}{l}\text { Diretor de Marketing e } \\
\text { Experiência do Usuário }\end{array}$ & 30 & 7 & Sim & Não & Sim \\
\hline 6 & Sócio fundador & Presidente/CEO & 32 & 12 & Sim & Não & Não \\
\hline 7 & Sócio fundador & Presidente/CEO & 32 & 2 & Sim & Não & Sim \\
\hline 8 & Sócio fundador & Presidente/CEO & 27 & 4 & Sim & Sim & Não \\
\hline 9 & Sócio fundador & Presidente/CEO & 24 & 4 & Não & Não & Não \\
\hline 10 & Sócio fundador & Presidente/CEO & 35 & 5 & Sim & Sim & Não \\
\hline 11 & Sócio fundador & Presidente/CEO & 29 & 6 & Não & Não & Sim \\
\hline 12 & Funcionário & $\begin{array}{c}\text { Diretor de Aquisição de } \\
\text { Usuários }\end{array}$ & 36 & 2 & $\mathrm{Sim}$ & Não & Não \\
\hline
\end{tabular}

Fonte: Elaborado pelo autor, com base nos dados da pesquisa.

Os entrevistados são pessoas na faixa etária de 30 anos (32 anos, em média, sendo 24 anos, no mínimo, e 40 anos, no máximo), podendo, ou não, possuir experiência empreendedora 
prévia ou experiência em outros setores. O que pode indicar em alguma medida o nível de comprometimento com a empresa avaliada é a existência, ou não, de uma ocupação paralela, ou seja, se o entrevistado possui outros negócios ou faz outras atividades como projetos free lancers para complementar a renda. 4 (quatro) entrevistados declararam que complementavam a renda ou que possuíam como fonte de renda principal outras atividades não associadas à empresa-objeto da pesquisa.

Refletindo o cenário do mercado, todos os entrevistados são homens e possuem, em geral, alto nível educacional. Uma mulher, CEO de uma empresa da região sudeste, havia, $a$ priori, aceitado o convite da pesquisa, mas por questões de disponibilidade da agenda, ela não pôde participar em tempo hábil até o fechamento da pesquisa de campo.

O Quadro 5 mostra o grau de escolaridade dos entrevistados. Dentre os entrevistados, 10 (dez) concluíram alguma graduação e 5 (cinco) concluíram algum tipo de pós-graduação (MBA, Mestrado ou outra especialização). Como esperado, as formações, de forma geral, possuem uma relação direta (Design de jogos, Design de Games, Game Art, Design etc.) ou indireta (Ciências da Computação, Design de Interação, Design Gráfico etc.) com a área de jogos digitais. Até mesmo os 2 (dois) entrevistados sem curso de graduação tiveram contato (de forma autodidata ou por meio de cursos técnicos) com temas relacionados à programação ou ao design de jogos.

Quadro 5 - Grau de escolaridade dos entrevistados

\begin{tabular}{|c|c|c|}
\hline Ent. & Graduação/Curso Técnico & Pós-graduação \\
\hline 1 & Não possui (somente ensino médio) & Não possui \\
\hline 2 & Não possui (somente ensino médio) & Não possui \\
\hline 3 & Sistemas de Informação & $\begin{array}{c}\text { Mestrado em Engenharia e Sistemas de Automação e } \\
\text { Inteligência Artificial }\end{array}$ \\
\hline 4 & Tecnólogo em Mecânica & Não possui \\
\hline 5 & Design Gráfico & Pós em Game Art e Design \\
\hline 6 & Jogos Digitais & Não possui \\
\hline 7 & Comunicação Social / Design Gráfico & Não possui \\
\hline 8 & $\begin{array}{c}\text { Design de Games e Mídia Digital/ Design } \\
\text { de Interação }\end{array}$ & $\begin{array}{l}\text { MBA em Comunicação e Marketing/ } \\
\text { Mestrado em Comunicação Social }\end{array}$ \\
\hline 9 & Direito/ Design de Jogos & Não possui \\
\hline 10 & Ciências da Computação & Mestrado em Ciências da Computação \\
\hline 11 & Ciências da Computação & Não possui \\
\hline 12 & Matemática Aplicada & Mestrado em Economia \\
\hline
\end{tabular}

Fonte: Elaborado pelo autor, com base nos dados da pesquisa.

Somente o Entrevistado 8 possui formação relacionada com a área de marketing e com a área administrativa de forma geral (MBA em Comunicação e Marketing). Durante as 
entrevistas, ficou clara a diferença de perspectiva, percepções e conhecimentos acerca da gestão de marketing desse entrevistado frente aos demais, fator que pode também ter contribuído para o $2^{\circ}$ maior tempo de entrevista e o $2^{\circ}$ maior número de palavras registradas na transcrição, verificados no item 4.6.4 Volumetria e Codificação dos Dados Avaliados.

\title{
4.6 TRATAMENTO E ANÁLISE DE DADOS
}

Tendo em vista o problema de pesquisa, os objetivos e a natureza dos dados, optou-se pela aplicação de preceitos da análise de conteúdo que, segundo Bardin (2011, p. 37), refere-se a:

\begin{abstract}
Um conjunto de técnicas de análise das comunicações visando obter, por procedimentos sistemáticos e objetivos de descrição do conteúdo das mensagens, indicadores (quantitativos ou não) que permitam a inferência de conhecimentos relativos às condições de produção/recepção (variáveis inferidas) dessas mensagens.
\end{abstract}

Foi realizada a análise de conteúdo de uma comunicação dual (entrevistador e entrevistado) em forma linguística e oral, convertida em texto por meio de um processo de transcrição das falas dos entrevistados. Em um primeiro momento foram realizadas descrições analíticas que lançaram mão de métodos quantitativos de análise com o suporte do programa NVivo $^{57}$ (Versão Março de 2020). Em um segundo momento, e como principais razões de se adotar a análise de conteúdo, foram realizadas inferências sobre os conteúdos, abrindo caminho para a interpretação e a obtenção dos significados e implicações dos resultados no mundo real (BARDIN, 2011).

Dentre as abordagens de análise de conteúdo possíveis, que surgem de forma direta ou indireta na interpretação dos resultados, pode-se destacar, por exemplo, a análise de avaliação (ex.: atitudes positivas ou negativas em relação a um determinado assunto); a análise de enunciação (ex.: as escolhas de palavras e as formas de falar do entrevistado); a análise de expressões (ex.: variedade do vocabulário); ou a análise das relações (ex.: aparição constante de um assunto relacionado a outro). As técnicas e os processos envolvidos no tratamento e a análise de dados do presente estudo são firmados nas bases da análise temática do conteúdo, que se trata de uma análise transversal que realiza "recortes" do conjunto de texto das entrevistas e dos segmentos em temas ou categorias, tendo como prioridade a frequência de ocorrência, a intensidade e as múltiplas comparações (BARDIN, 2011).

\footnotetext{
${ }^{57}$ NVivo Qualitative Data analysis Software. Site oficial disponível em: https://www.qsrinternational.com/nvivoqualitative-data-analysis-software/home. Acesso em: 5 ago. 2020.
} 
A análise temática de conteúdo envolve uma série de decisões a serem tomadas, dentre as quais, Braun e Clarke (2008) destacam:

- Indução ou dedução (guiado pela teoria) na geração de temas: pela emergência prédeterminada de temas, o presente estudo lançou mão de conceitos oriundos da teoria da gestão de marketing, mais especificamente da Escola de Administração de Marketing (orientação dedutiva). Mesmo assim, há um processo indutivo de geração de subtemas a partir de grandes conceitos, fazendo jus ao seu caráter exploratório e à abertura para novos achados.

- Orientação experimental ou crítica: optou-se por uma orientação experimental, sem pressupostos ou julgamentos preliminares, na descrição e no levantamento dos dados, com base na aplicação de técnicas quantitativas. Após esse primeiro momento, com os dados em mãos e com base na experiência acadêmica e profissional do autor, uma visão mais crítica e questionadora substituiu essa postura mais passiva e contemplativa dos dados.

- Perspectiva realista ou teórica: a teoria desempenha um papel importante para guiar a geração de temas, mas a interpretação dos resultados pautou-se, prioritariamente, numa perspectiva prática, levando-se em consideração o contexto e a situação real das empresas entrevistadas, ou seja, podem ser admitidas inferências que possam contradizer preceitos e expectativas teóricas estabelecidas em outros estudos.

Portanto, mesmo com um processo flexível e semiestruturado, a análise temática de conteúdo seguiu um guia base de procedimentos, oriundos de tais decisões, descritos a seguir.

\subsubsection{Processo de Análise Temática do Conteúdo}

Por sua correspondência prática com o contexto e com as necessidades do estudo, optouse pelo processo de Braun e Clarke (2008), que considera 6 (seis) fases para a geração de uma produtiva análise temática do conteúdo, conforme descrito a seguir. 
i) Familiarização com os dados

Essa fase envolveu a transcrição dos dados, sua leitura, releitura e anotação de ideias iniciais. No que diz respeito à transcrição, procurou-se um equilíbrio entre a fidedignidade do conteúdo das falas dos entrevistados e a eliminação de especificações irrelevantes para a análise, tais como: aspectos narrativos envolvendo tempos de pausas; relutâncias; oscilações de humor; vícios de linguagem etc. Fora isso, o conteúdo das falas foi totalmente preservado, sem cortes ou substituições de termos ou palavras utilizadas, mesmo que contivessem erros gramaticais ou conceituais explícitos. Finalizadas as transcrições, realizou-se a leitura inicial de todas as entrevistas - procedimento descrito por Bardin (2011) como análise flutuante. Posteriormente, foi realizada uma releitura profunda com anotações que envolveram observações, interpretações e ideias de análise.

ii) Geração de códigos iniciais

Foram criados códigos para a segmentação do conteúdo. Por exemplo: determinou-se que trechos como "a venda de pacotes de moeda virtual é o que mais gera receita para nossa empresa" seriam codificados como Estratégia de Monetização, da mesma forma como outros códigos também foram criados para segmentar o conteúdo de forma exaustiva, gerando uma grande lista de códigos a serem posteriormente revisados, mesclados ou agrupados em outros códigos dentro de um tema específico. Bardin (2011) refere-se a esse processo como criação de unidades de registro (códigos) que representam ou estão inclusas em unidades de contexto (temas).

iii) Busca por temas

Com os textos dos documentos completamente segmentados por códigos, a busca por temas foi facilitada por conta do trabalho de revisão bibliográfica previamente relatado. Para o código Estratégia de Monetização, por exemplo, determinou-se que ele faria parte do tema Preço, que também poderia envolver outros códigos como Formas de Monetização ou Contratação Business to Business (B2B). Tais temas e subtemas foram designados de forma semântica (quando o entrevistado mencionava explicitamente o tema "preço") ou, como ocorreu na maioria das vezes, de forma latente (não há menção ao tema preço, mas se encontra implícito na frase ou trecho da fala do entrevistado). 
iv) Revisão dos temas

Essa revisão perdurou durante praticamente todo o processo de análise por sempre ser possível encontrar interseção entre os temas da mesma categoria, disputando os mesmos espaços de texto, códigos duplicados ou subtemas muito abrangentes ou muito específicos.

v) Definição e nomeação de temas

Mais do que a nomenclatura dos temas (já definida por preceitos teóricos), tal fase no presente estudo envolveu fazer escolhas como a marcação de um trecho por um tema que poderia também ser marcado por outro. Dessa forma, recorreu-se ao conceito de unidade de contexto de Bardin (2011), para priorizar temas mais aderentes ao contexto ou ao momento da fala. Por exemplo: ao falar de um assunto que poderia se enquadrar tanto em Praça quanto em Promoção, optava-se por Praça simplesmente pelo fato de o tema Promoção já ter sido tratado anteriormente ou por já ter sido explicitamente encerrado.

vi) Produção do relatório

No caso, o relatório que envolve o problema, os objetivos, a metodologia e os principais resultados da análise temática de conteúdo é a própria dissertação. Nas próximas seções serão apresentados o ferramental analítico e as técnicas de análise utilizadas.

\subsubsection{Ferramental Analítico}

O principal instrumento de análise e de interpretação dos resultados de dados de tal natureza é o próprio pesquisador, pois a avaliação depende intimamente do contexto, de experiências pessoais e de nuances que ainda não são capazes de serem capturadas por máquinas. No entanto, softwares com módulos de análise de conteúdo podem ser extremamente úteis para a manipulação de grandes volumes de dados e para a execução de rotinas, diminuindo consideravelmente o tempo necessário para que o pesquisador cumpra com seus objetivos (BARDIN, 2011).

Com isso em mente, optou-se pela utilização do software NVivo, que auxilia na organização e gestão dos dados, além de facilitar a classificação e a interconexão de temas, 
executando algoritmos de análise diversos, que envolvem contagens, cruzamentos, correlações e visualizações gráficas dos dados avaliados.

Mesmo que não haja nenhuma linearidade inerente ao processo de tratamento e de análise de conteúdo, o NVivo permite a execução de certos ciclos de análise que o pesquisador precisará repetir por uma quantidade considerável de vezes. Esse ciclo envolve a importação e a organização dos documentos, sua exploração, a aplicação dos códigos, a execução de rotinas de busca ou de contagem de termos (consultas), um olhar mais aprofundado sobre as falas dentro de um código ou de um tema específico (revisão), sua visualização e a geração contínua de anotações, lembretes e observações. O ciclo de análise utilizando o software NVivo está resumido na Figura 17 a seguir.

Figura 17 - Ciclo de análise utilizando o software NVivo

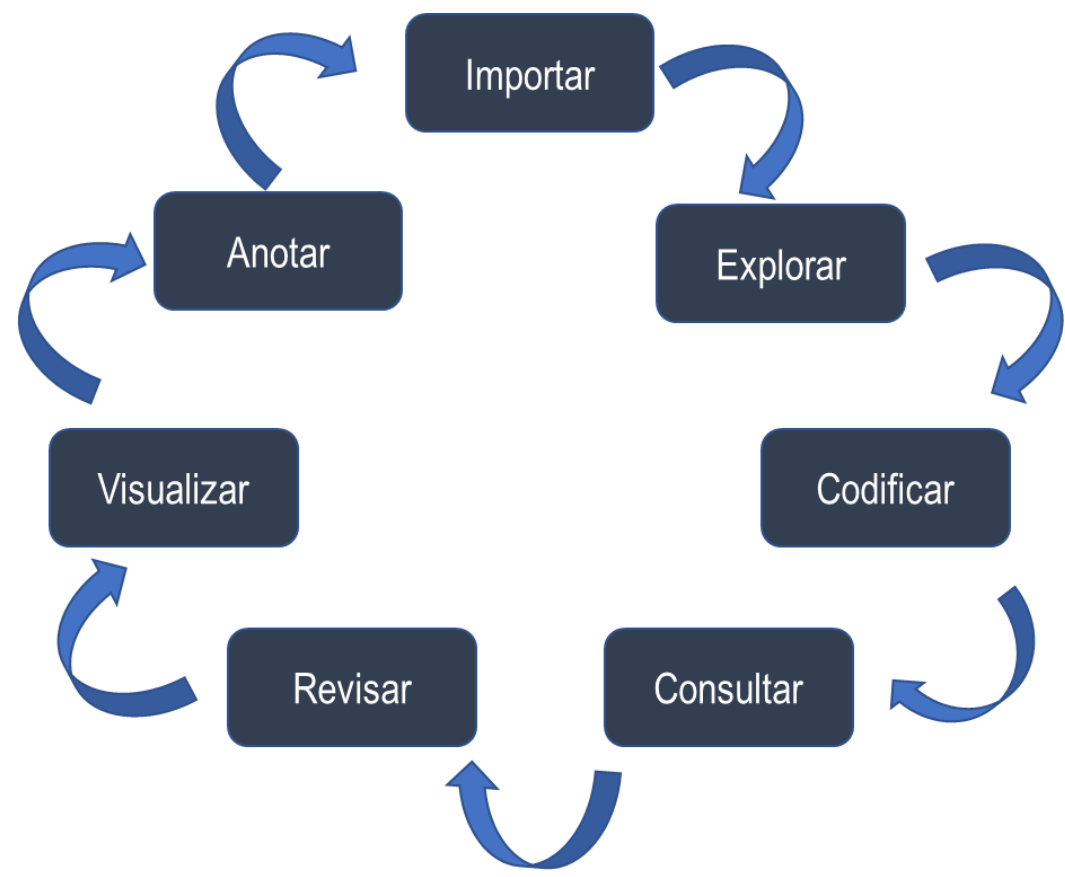

Fonte: Adaptado de QSR International (2020, p. 1, tradução nossa).

Além do software NVivo, foram utilizados o $\operatorname{Excel}^{58}$ e o IBM SPSS ${ }^{59}$ para manipulações pontuais, cruzamentos e visualização de dados quantitativos.

\footnotetext{
${ }^{58}$ Microsoft Excel Spreadsheet Software. Site oficial disponível em: https://www.microsoft.com/en-ww/microsoft365/excel. Acesso em: 20 mar. 2021.

${ }_{59}$ SPSS Statistics Software. Site oficial disponível em: https://www.ibm.com/analytics/spss-statistics-software. Acesso em: 20 mar. 2021.
} 


\subsubsection{Técnicas de Análise de Dados}

A codificação temática foi a técnica primordial de análise de dados utilizada no presente estudo. Foi descrita anteriormente como parte do processo de Brawn e Clarke (2008) e implica na segmentação do conteúdo das entrevistas em temas e subtemas, seguindo as regras de fragmentação da comunicação de Berelson ${ }^{60}$ (1952 apud Bardin, 2011), a saber:

- Homogeneidade: não se misturam temas de uma mesma categoria em um mesmo segmento de texto;

- Exaustividade: todo o conteúdo das entrevistas foi segmentado, codificado e designado a temas específicos;

- Exclusividade: nesse quesito, a regra foi flexibilizada para abarcar segmentos de texto que faziam parte de categorias temáticas distintas. Por exemplo: foram atribuídos e cruzados os códigos Produto (categoria: gestão de marketing) e Conceito na fase de Pré-Produção do jogo (categoria: fases de desenvolvimento). A regra de exclusividade foi aplicada entre códigos pertencentes à mesma categoria;

- Pertinência: foram criados somente códigos que fizessem parte do contexto estudado, mesmo que o entrevistado se deslocasse ligeiramente da temática (no caso de deslocamento total, como conversas sobre clima, política, esportes ou outros assuntos, o conteúdo não foi sequer transcrito, como mencionado anteriormente).

Outra técnica utilizada foi a contagem de frequência de termos e palavras que pode despertar (por presença ou ausência) questões pertinentes em determinado contexto que irão posteriormente trazer compreensões mais profundas sobre o fenômeno, superando a dicotomia análise qualitativa versus a análise quantitativa (BARDIN, 2011). Essas frequências são expressas em formas relativas ou absolutas, com cruzamentos com outras variáveis de interesse em quadros de dupla entrada e visualizações em formas de nuvens de palavras e árvores de

\footnotetext{
${ }^{60}$ BERELSON, B. Content analysis in communication research. [S.1.]: Free Press, 1952.
} 
palavras, que centralizam um termo específico e mostram tudo o que foi falado antes (à esquerda) e depois (à direita) de tal termo.

Para melhor visualização de conceitos e das relações entre variáveis, também foram utilizadas técnicas de visualização como mapas mentais, fluxogramas e outros métodos de visualização constituídos a partir de um processo criativo, semiestruturado e com alta dependência dos aprendizados adquiridos pelo pesquisador por meio das entrevistas ou por outros materiais disponíveis.

Como forma de se encontrar estruturalmente as similaridades e as diferenças entre o conteúdo avaliado de cada entrevista, também foram utilizadas análises de clusters, que se constituem, na prática da análise de conteúdo, na aplicação de coeficientes de correlação entre todas as combinações de palavras e de códigos utilizados em cada entrevista, gerando um dendrograma hierárquico que separa as entrevistas em grupos de dois ou mais clusters, evidenciando a similaridade do conteúdo entre as do mesmo grupo, ao mesmo tempo em que aponta a dissimilaridade em relação aos demais grupos ${ }^{61}$ (EVERITT; LANDAU; LEESE, 2001).

O presente trabalho, portanto, é empírico - por trabalhar com a realidade de empresas brasileiras de jogos digitais; reproduzível e objetivo - por elencar de forma transparente e detalhada os métodos utilizados para obtenção dos resultados; analítico - por seguir parâmetros consolidados de análise temática do conteúdo; dirigido pela teoria - por trazer fundamentos teóricos relacionados com o universo de marketing e das Indústrias Criativas; lógico - por confrontar achados do passado com os dados primários coletados pelas entrevistas; e rigoroso - por utilizar uma série de recursos como técnicas de desenho de roteiro, algoritmos de análise de conteúdo e formas testadas de abordagem de entrevistados para minimização de erros (HAIR-JR et al., 2005).

\subsubsection{Volumetria e Codificação dos Dados Avaliados}

As 12 (doze) entrevistas realizadas resultaram 12 horas e 47 minutos de gravações, totalizando um volume de 84.168 palavras que, transcritas, decorreram 159 páginas em formato A4 e fonte 12. Para avaliar o texto segundo os preceitos da análise temática de conteúdo foram

\footnotetext{
${ }^{61}$ Esse guia prático mostra mais detalhadamente como uma análise de cluster do conteúdo é realizada pelo NVivo. Disponível em: http://helpnv11.qsrinternational.com/desktop/deep concepts/how are cluster_analysis_diagrams_generated_htm. Acesso em: 20 dez. 2020.
} 
criados 57 (cinquenta e sete) códigos distintos de unidades temáticas aplicados a 4.584 segmentos de texto (referências). Os dados apresentados na Tabela 1 permitem observar individualmente os volumes que, de certa forma, traduzem os esforços necessários para realização, transcrição e codificação das entrevistas.

Tabela 1 - Volumetria e codificação dos dados avaliados

\begin{tabular}{cccccc}
\hline Entrevista & Tempo (HH:MM:SS) & Palavras & Páginas & Códigos & Referências \\
\hline 1 & $01: 05: 39$ & 7.233 & 14 & 56 & 535 \\
2 & $01: 16: 39$ & 8.785 & 16 & 53 & 488 \\
3 & $00: 47: 55$ & 5.609 & 11 & 57 & 368 \\
4 & $00: 56: 41$ & 6.241 & 12 & 57 & 447 \\
5 & $00: 50: 38$ & 5.453 & 11 & 55 & 331 \\
6 & $01: 04: 31$ & 7.554 & 14 & 36 & 216 \\
7 & $01: 28: 16$ & 10.517 & 18 & 57 & 500 \\
8 & $01: 20: 57$ & 9.537 & 17 & 57 & 514 \\
9 & $00: 49: 00$ & 4.814 & 10 & 54 & 329 \\
10 & $01: 08: 54$ & 7.155 & 13 & 43 & 261 \\
11 & $01: 10: 56$ & 7.603 & 15 & 45 & 345 \\
12 & $00: 46: 46$ & 3.667 & 8 & 43 & 250 \\
\hline Total & $12: 46: 52$ & 84.168 & 159 & 613 & 4.584 \\
\hline Média & $01: 03: 54$ & 7.014 & 13 & 51 & 382 \\
\hline Desvio Padrão & $00: 13: 54$ & 1.989 & 3 & 7 & 112 \\
\hline Mediana & $01: 05: 05$ & 7.194 & 14 & 55 & 357 \\
\hline Mínimo & $00: 46: 46$ & 3.667 & 8 & 36 & 216 \\
Máximo & $01: 28: 16$ & 10.517 & 18 & 57 & 535 \\
\hline
\end{tabular}

Fonte: Elaborada pelo autor, com base nos dados da pesquisa e com o uso da ferramenta NVivo.

O tempo máximo previsto de entrevista informado aos respondentes foi de 1 hora e 30 minutos e não foi ultrapassado. Em média as entrevistas tiveram duração de 1 hora e 4 minutos, com um desvio padrão de 14 minutos. A entrevista 7 foi a de maior duração, com 1 hora e 28 minutos.

Em termos de volume de conteúdo, a média e a mediana de palavras por entrevista foram similares (7.014 palavras em média e uma mediana de 7.194 palavras), com um desvio padrão de 1.989 palavras. Esses resultados mostraram bom rendimento e consistência de conteúdos fornecidos pelos entrevistados, orbitando na faixa de 5 a 9 mil palavras (aplicando-se um desvio padrão para baixo e para cima da média). A entrevista 7, com maior tempo de duração, 
naturalmente também rendeu o maior número de palavras (10.517). Da mesma forma, a entrevista 12, com o menor tempo de duração, também rendeu o menor número de palavras (3.667).

A entrevista 12, exclusivamente, sofreu por limitações de fornecimento de informações por parte do entrevistado, devido a políticas de privacidade de dados da empresa em questão. É interessante notar o contraste em relação à entrevista 3, que possui um tempo de duração similar, no entanto, apresenta praticamente 2 mil palavras a mais. São dados menos profundos sobre os aspectos de gestão de marketing da empresa entrevistada, considerados de forma ponderada frente às demais entrevistas.

Dos 57 códigos criados, em média, 51 foram aplicados para segmentar o texto de cada entrevista, representando os temas e os subtemas a serem analisados. Cada entrevista segmentou em média 382 unidades de texto, denominadas referências (expressões, parágrafos e principalmente frases atribuídas a um código e a um tema específicos). 


\section{DISCUSSÃO DOS RESULTADOS}

O processo de leitura flutuante, releitura e anotações, recomendado por Bardin (2011), sobre os principais pontos das entrevistas trouxe à superfície as dificuldades de se avaliar a maturidade ou a qualidade da gestão de marketing das empresas sem aterrissar sobre aspectos como falta de recursos financeiros, técnicos e, principalmente, humanos. Além disso, observouse que deveriam ser levadas em consideração a natureza da oferta, suas diferentes fases de elaboração e outras especificidades.

Sendo assim, a análise da GESTÃO DE MARKETING DAS EMPRESAS (Seção 5.3) (vértice do triângulo, em vermelho) possuiu como base os resultados da análise do HISTÓRICO E CARACTERÍSTICAS DAS EMPRESAS (Seção 5.1), que deram luz aos principais acontecimentos desde sua fundação e atuais desafios, além dos resultados da análise da NATUREZA E PROCESSOS ATRELADOS À OFERTA (Seção 5.2) - ou produtos e serviços (vértices do triângulo, em azul), conforme ilustrado na Figura 18 a seguir.

Figura 18 - Estrutura-base da análise temática de conteúdo

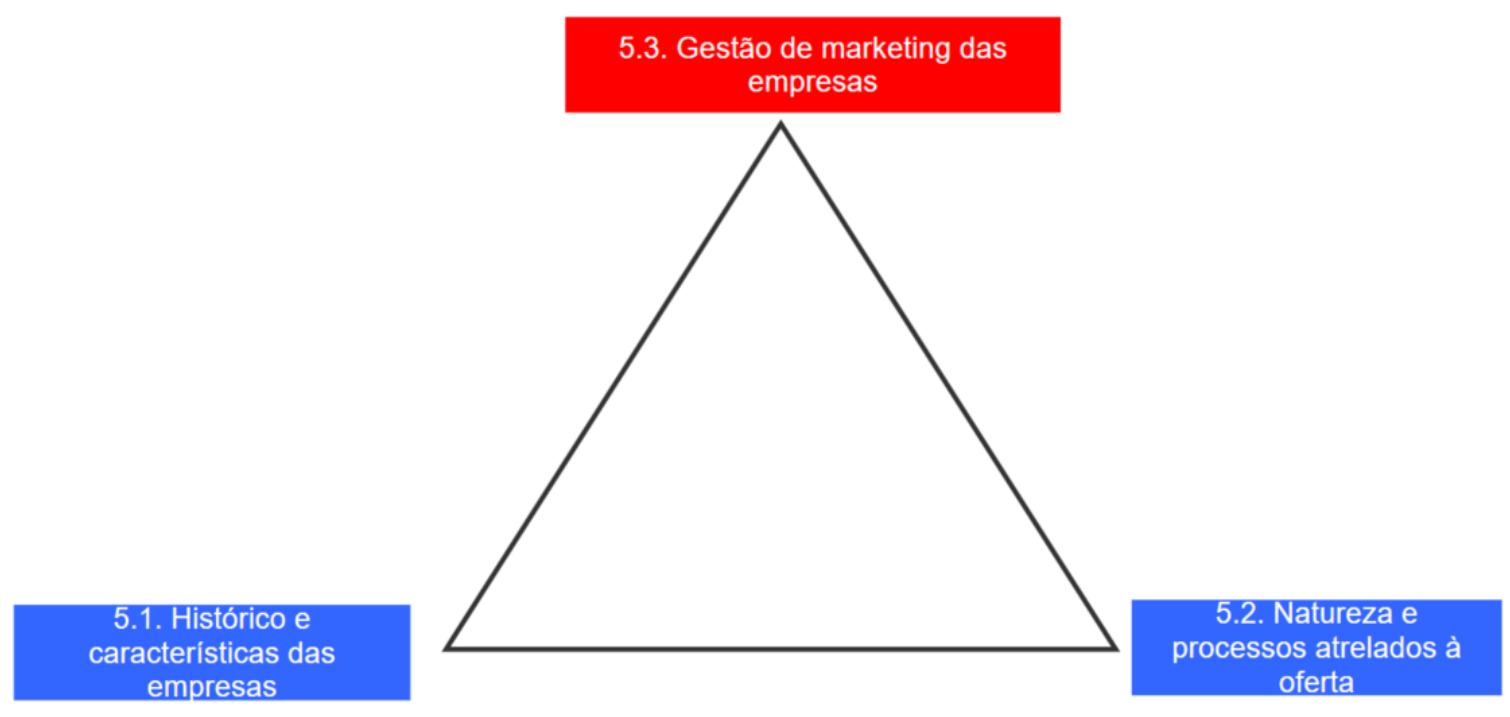

Fonte: Elaborada pelo autor, com o uso da ferramenta NVivo.

A análise do histórico e das características de cada empresa entrevistada foi necessária para não gerar nem expectativas e nem avaliações equivocadas, comparando-as sem as devidas ponderações com empresas de maior nível de maturidade ou de maiores recursos, assim como foi necessário entender a natureza da oferta e de seus processos. Trata-se, portanto, de um produto digital, criativo e que pode tanto ser vislumbrado sob a perspectiva clássica de produto ou sob a perspectiva de serviço. 


\subsection{HISTÓRICO E CARACTERÍSTICAS DAS EMPRESAS}

Todas as menções relacionadas com o histórico das empresas, desde sua fundação até as perspectivas de futuro foram segmentadas com base nos códigos descritos na Figura 19: situação, motivação, exploração, início, equipe, desafios e perspectivas. Esses códigos temáticos encontram um sentido narrativo, temporal e lógico, conforme também retratado na figura em questão (Figura 19) e explicados detalhadamente a seguir.

Figura 19 - Histórico geral da trajetória das empresas analisadas

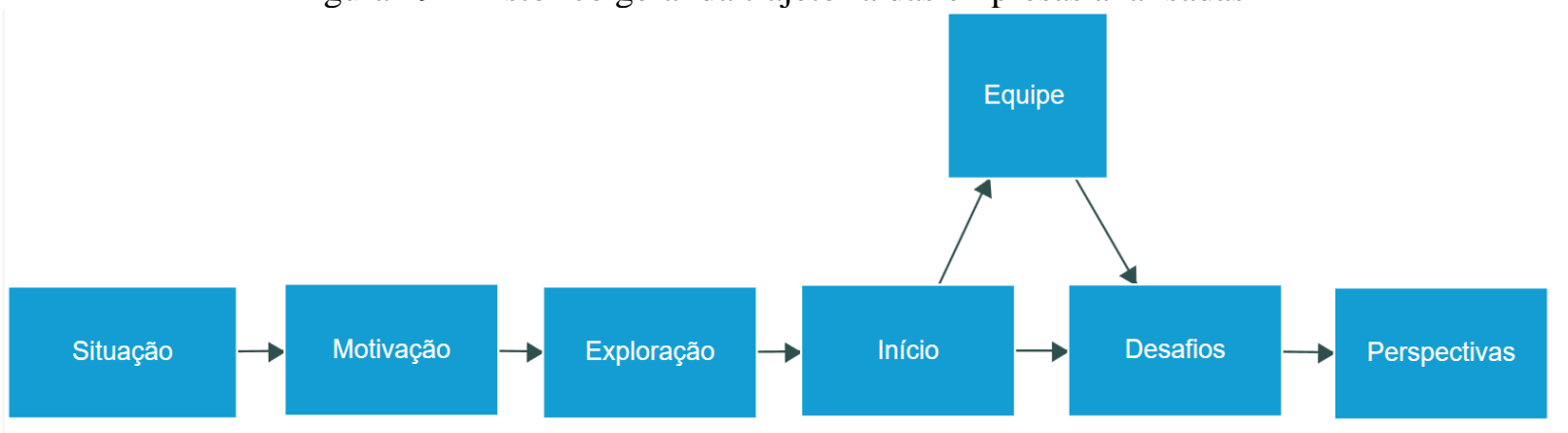

Fonte: Elaborada pelo autor, com base nos dados da pesquisa e com o uso da ferramenta NVivo.

a) Situação

No que diz respeito à situação, os entrevistados relataram eventos ocorridos anteriormente à ideia de início do negócio da empresa. Geralmente, referiam-se a situações que os motivaram a montar seus próprios negócios de jogos digitais como o fato de não gostarem do emprego anterior, ou de já terem montado um negócio em uma área correlata, ou de já terem saído de uma graduação ou de um curso na área e terem traçado tal caminho como natural, o que poderia indicar uma mentalidade mais empreendedora do que gestora dos egressos desses cursos, fosse por vontade ou fosse por necessidade.

b) Motivação

A motivação para trabalhar com jogos foi muito consistente entre os entrevistados. Alguns se referiram à motivação como um clichê ou algo óbvio nessa indústria: "o sonho de se trabalhar com jogos". Procurando entender essa "obviedade", pode-se considerar que era um tipo de atividade que acompanhou os empreendedores por toda a sua vida, desde sua infância, tendo contato com diferentes tipos de jogos e experiências de entretenimento virtual. Além disso, geralmente se tratava de um produto que possuía o propósito de divertir, diferentemente 
de outros ramos e indústrias que podem ser considerados "chatos" ou "desinteressantes", o que também foi observado em algumas das entrevistas.

\section{c) Exploração}

A fase de exploração foi similar ao conceito descrito por Hisrich, Peters e Sheperd (2014) como a 'exploração de uma nova entrada', que representa a oportunidade de entrada em um novo negócio. Geralmente, os entrevistados começaram a entrar em contato com a indústria a partir da formação na graduação, curso ou eventos da área e ao se unirem a outras pessoas (daí também a existência frequente de dois ou mais sócios) para iniciarem um novo negócio. Algo interessante e até inesperado foi o nível de preparo desses empreendedores, que, no geral, montaram seus próprios negócios contando com fatores como: alta escolaridade, especialização autodidata ou formal desde as áreas mais básicas da empresa, divisão de tarefas técnicas e administrativas e busca por financiamento público ou privado, de profissional a amador (família e amigos).

\section{d) Início}

O início do negócio muitas vezes contou com a existência de um projeto principal denominado pelo autor "o jogo dos sonhos". Foi o produto que representou os valores e a visão da empresa a partir de seu início, sendo considerado, por seus criadores, um investimento de alta probabilidade de retorno, mas que geralmente entrou em conflito com os desafios encontrados ao longo da jornada. Também houve empresas menos apegadas a esses tipos de jogos e elas os trataram como projetos que precisariam ser objetivamente avaliados e, nos casos em que não correspondessem às expectativas comerciais, imediatamente seriam descartados. Isso foi uma das características mais marcante nas empresas maiores (empresas 3 e 12, de maior porte, tidas como outliers) ou nas empresas em estágios mais avançados em termos de gestão de marketing (como a empresa 8 , também considerada outlier em função de sua finalidade e de seu conteúdo, conforme poderá ser observado nas seções seguintes).

\section{e) Equipe}

O início estava atrelado à formação de uma Equipe inicial que compunha o time de sócios da empresa e fazia a divisão do trabalho mencionada anteriormente. Os cargos e/ou funções mais comumente citados foram: Programador, Game Designer, Artista e Comercial. Essas funções são essenciais ao negócio, sem muito espaço para atividades de gestão ou de 
inteligência de marketing. Mais uma vez, somente as maiores empresas (empresas 3 e 12) relataram a existência de equipes ou de departamentos dedicados a marketing em seus quadros.

\section{f) Desafios}

Os segmentos de texto classificados como desafios designam as dificuldades e os maiores empecilhos enfrentados pelas empresas durante seus anos de existência. O que chamou a atenção nessa fase foi a grande ocorrência da palavra "não", que superou quantitativamente todas as demais citadas -1.166 vezes, representando um percentual ponderado pelo número de caracteres de $3,1 \%$ de todo o texto avaliado (uma grande proporção em comparação aos $80 \%$ dos demais termos que representaram individualmente $0,22 \%$ ou menos do texto). A Figura 20, a seguir, demonstra o volume de ocorrência da palavra "não" em relação às demais, em forma de nuvem de palavras.

Figura 20 - Nuvem de palavras nos segmentos de texto marcados como "desafios"

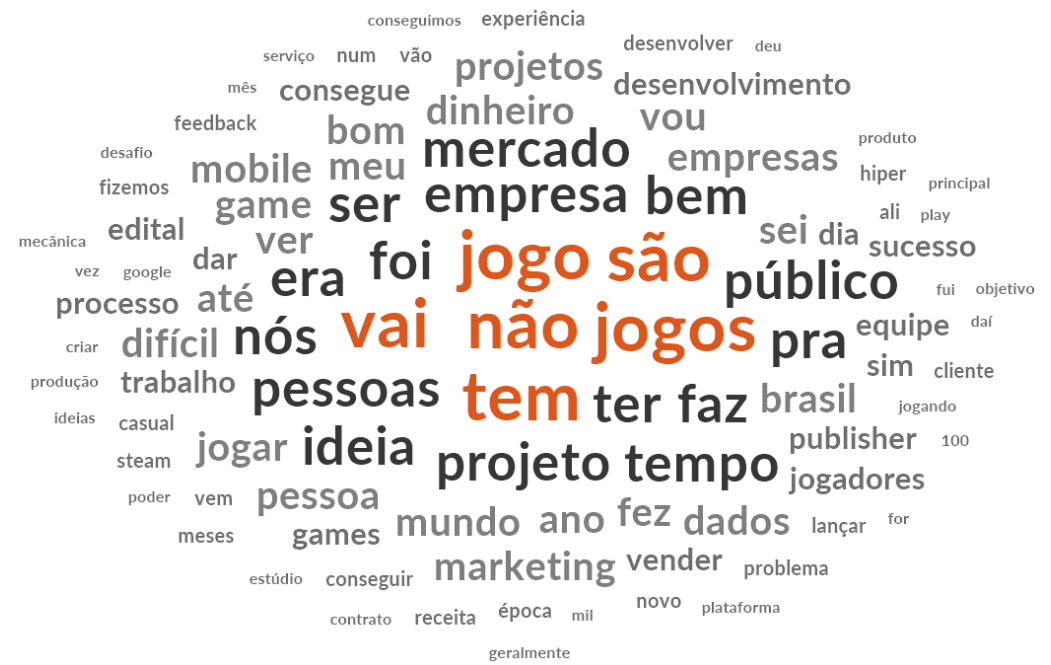

Fonte: Elaborada pelo autor, com base nos dados da pesquisa e com o uso da ferramenta NVivo.

A palavra "não", nos conteúdos avaliados, geralmente denota uma impossibilidade, uma limitação a ser contornada. De fato, a palavra "não" foi a que centralizou os conteúdos que descreveram os desafios enfrentados pelas empresas analisadas. A árvore de palavras da Figura 21 evidencia quais foram as frases ditas após a palavra "não", obtidas a partir da declaração dos entrevistados. 
Figura 21 - Árvore de palavras ramificadas pela palavra-tronco "não" 62

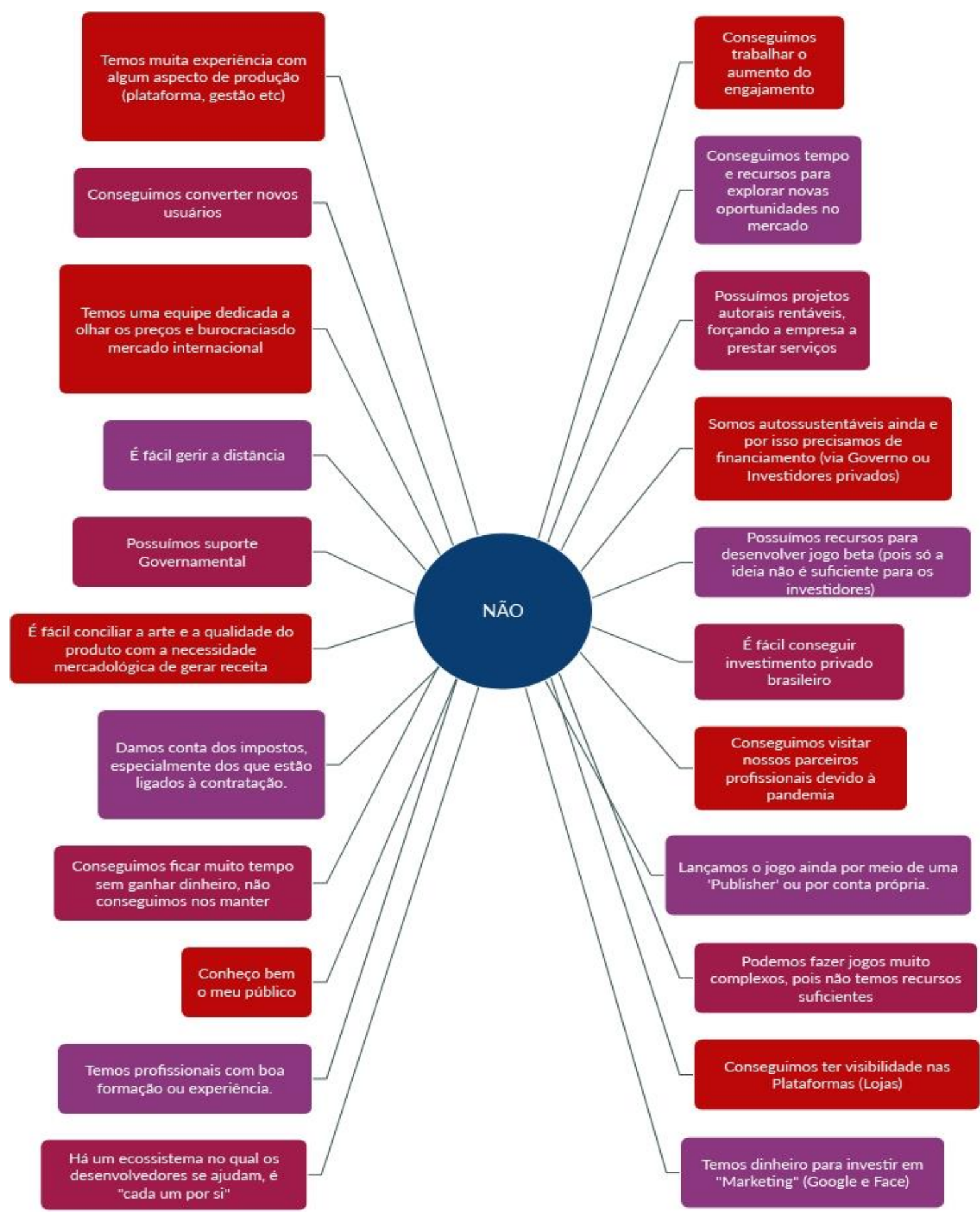

Fonte: Elaborada pelo autor, com base nos dados da pesquisa e com o uso da ferramenta NVivo.

${ }^{62}$ Geralmente, as árvores de palavras são a representação de textos (“galhos”) que vêm antes (à esquerda) e depois (à direita) da palavra "tronco" (nesse caso, a palavra "não"). Por exemplo: "Deixamos de pensar nisso, pois não podemos deixar de priorizar outras atividades". "Deixamos de pensar nisso" é o que vem antes (à esquerda) e "podemos deixar de priorizar outras atividades" é o que vem depois (à direita) da palavra-tronco. No estudo, as frases à esquerda da palavra "não" trouxeram poucas contribuições, enquanto as frases à direita foram essenciais para a compreensão dos desafios enfrentados pela empresa, sendo as únicas representadas na Figura 21. Ou seja, todos os textos representados, incluindo os que estão à esquerda, dizem respeito ao que foi dito depois (à direita) da palavra tronco "não". 
Os desafios advindos dessas conexões com a palavra "não" foram frequentemente atrelados à falta de recursos financeiros ("ㅆño somos autossuficientes financeiramente", "não podemos criar jogos muito complexos, pois não temos verba", “não conseguimos muito tempo sem ganhar dinheiro, precisamos nos manter" - em referência a trabalhos terceirizados); à falta de recursos humanos ("não temos profissionais com boa formação ou experiência"); à gestão durante a pandemia ("não é fácil gerir a distância); e também à gestão de marketing ("não conheço bem meu público", "não conseguimos aumentar o engajamento dos nossos jogos", "não temos dinheiro para investir em marketing" - ressaltando a existência de outras áreas prioritárias para direcionamento dos escassos recursos) (Figura 21 na página anterior).

\section{g) Perspectivas}

Por fim, as perspectivas das empresas foram variadas. Alguns entrevistados foram mais pessimistas e outros mais otimistas em relação ao futuro. Quando se referiram ao mercado brasileiro, apontaram com frequência as dificuldades em relação à infraestrutura de Internet, à falta de profissionais qualificados (que, quando existem, saem do país para trabalhar em grandes empresas nos EUA, na Ásia ou na Europa) e à falta de estímulo governamental (visão mais pessimista). Por outro lado, acreditavam na prosperidade do próprio negócio, com base nos índices globais de crescimento da indústria, em novas tecnologias emergentes e em tendências promissoras (visão mais otimista).

\subsection{NATUREZA E PROCESSOS ATRELADOS À OFERTA}

Os tipos de jogos desenvolvidos pelas empresas analisadas também tendem a ser um reflexo da maioria da Indústria nacional; são jogos de menor complexidade, voltados a públicos considerados "casuais", que não demandam grande experiência, habilidades específicas ou dedicação intensiva para seu aproveitamento. Também tendem a ser jogos de menor investimento financeiro e que utilizam plataformas menos complexas para uso em computadores pessoais (personal computers - PC) - desktops ou notebooks - (jogos web ou inseridos nas redes sociais) ou dispositivos mobile (jogos para smartphones ou tablets) (Quadro $6)$. 
Quadro 6 - Tipos de jogos desenvolvidos pelas empresas analisadas

\begin{tabular}{|c|l|l|l|}
\hline Empresa & Finalidades & Complexidade & Dispositivos \\
\hline 1 & Entretenimento & Casual, Hardcore & Mobile, PC \\
\hline 2 & Entretenimento & Casual & Mobile \\
\hline 3 & Entretenimento & Casual & Mobile \\
\hline 4 & Entretenimento, Educação, Advergames & Casual & Mobile, PC \\
\hline 5 & Entretenimento, Educação, Advergames & Casual & Mobile, PC \\
\hline 6 & Entretenimento & Casual & Mobile, PC \\
\hline 7 & Entretenimento & Casual & Mobile \\
\hline $8 *$ & Entretenimento Adulto & Casual, Hipercasual, Hardcore & Mobile, PC \\
\hline 9 & Entretenimento, Advergames & Casual, Hipercasual & Mobile, PC \\
\hline 10 & Entretenimento, Educação & Casual, Hipercasual & Mobile, PC \\
\hline 11 & Entretenimento & Casual, Hardcore & Mobile, Console \\
\hline 12 & Entretenimento & Casual & Mobile \\
\hline
\end{tabular}

*Empresa considerada outlier em termos de finalidade dos jogos.

Fonte: Elaborado pelo autor, com base em dados da pesquisa.

Algumas empresas que compõem a amostra deste estudo trabalham, inclusive, com jogos hiper casuais, que são muito mais simples do que os jogos casuais, com desenvolvimento completo em apenas alguns dias e feitos para consumo imediato, geralmente atrelados a uma mecânica fácil e viciante, como é o caso do jogo Flap Bird ${ }^{63}$.

Os entrevistados que trabalham com essa modalidade relataram que muitas vezes o anúncio do jogo é criado antes mesmo do jogo em si, para ser aprovado por uma publicadora. Caso o custo de aquisição projetado compense o custo com a produção, o jogo é, então, desenvolvido. Além disso, trata-se de um tipo de jogo altamente massificado e com maior preocupação com o retorno financeiro do que com a qualidade ou com certos aspectos criativos.

\begin{abstract}
A ideia do jogo hiper casual é que ele é feito para todo mundo, não se faz marketing por target, tipo: 'é a galera de 10 a 20 anos que vai jogar e eu vou comprar anúncio pra esse cara'. Não, você vai fazer de 13 a 65 anos de idade. Quanto mais amplo você fizer, porque aí o custo de aquisição é baixíssimo, você consegue $\mathrm{R} \$ 0,30$ por instalação, e a conversão tem que ser alta, então a publicadora que você está trabalhando, a métrica dele [do jogo] tem que ser $40 \%$ de retenção no primeiro dia, então a pessoa jogou e ela tem que jogar no próximo dia, então mais $40 \%$ e o custo de aquisição tem que ser abaixo de U\$0,30, ou seja, é muito baixo (Entrevistado 7).
\end{abstract}

As Empresas 1, 8 e 11 chegaram a mencionar projetos mais complexos (jogos hardcore), mas que não chegaram a ser a maioria dos projetos em andamento. Em termos de finalidades, todas trabalham em algum nível com jogos de entretenimento, tendo também surgido finalidades de educação (Serious games) e de promoção de marcas (Advergames). A

${ }^{63}$ Flap Bird é um jogo do tipo side-scroller, feito para plataformas mobile, lançado em 2013 pelo vietnamita Nguyễn Hà Đông. Mais informações disponíveis em: https://flappybird.io/. Acesso em: 20 mar. 2021. 
Empresa 8 foi considerada outlier em termos de finalidades de seus jogos, dedicados ao público adulto, mas também com finalidade de entretenimento.

Os tipos de dispositivos utilizados pelas empresas são a consequência da natureza dos jogos desenvolvidos. Cada jogo pode ter uma versão para mais de um dispositivo, sendo os dispositivos móveis os mais comuns. Algumas empresas possuem maior foco em desenvolvimento de jogos de computador (web, redes sociais ou via download e instalação local), mas todas, em algum momento, declararam ter algum contato ou pretensão de desenvolver jogos mobile. No momento da entrevista, apenas uma das empresas analisadas estava desenvolvendo um jogo para consoles, que geralmente exige maior investimento por requisitos de produção e complexidade.

Para localizar os diferentes momentos de produção em que atividades de marketing poderiam ser aplicadas, extraíram-se dos textos, de forma direta ou indireta, etapas de produção que corresponderam em boa medida às etapas descritas por Chandler (2012) adaptadas à realidade dessas empresas, transformadas em códigos de segmentação de texto e ilustradas na Figura 22 a seguir:

Figura 22 - Processo geral de produção de jogos das empresas analisadas
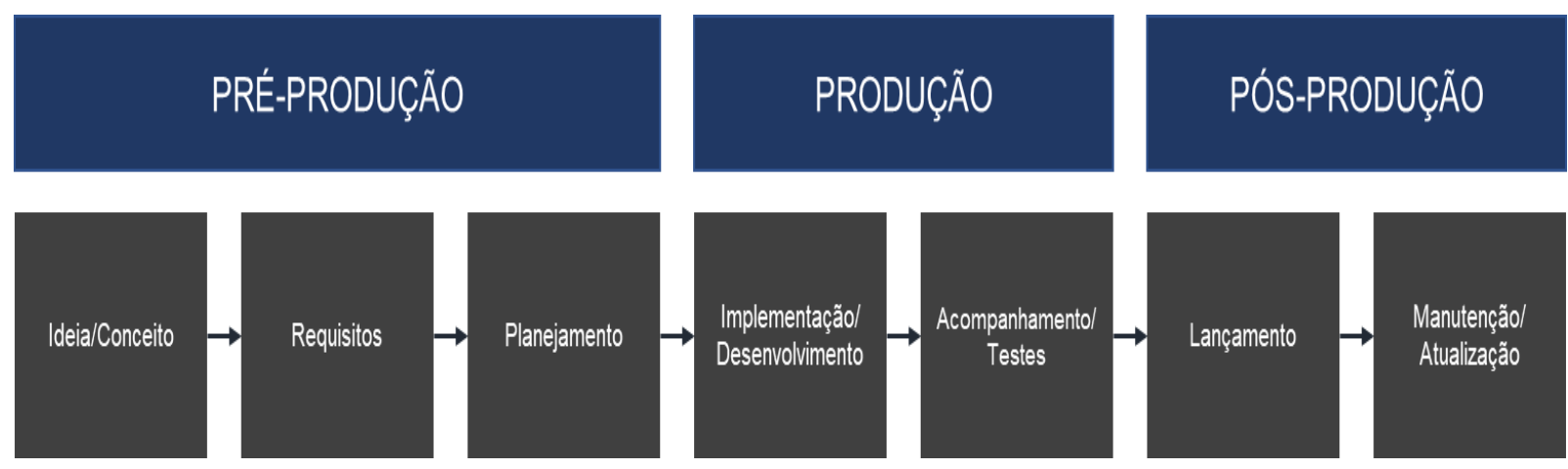

Fonte: Elaborada pelo autor, com base em Chandler (2012, p. 5), nos dados da pesquisa e com o uso da ferramenta NVivo.

As três grandes fases de produção são a pré-produção, a produção e a pós-produção. A pré-produção refere-se a todo o processo de preparação para início das atividades de programação e de desenvolvimento do jogo em si. É o momento em que as ideias sobre o jogo são elaboradas; a definição de público-alvo e as pesquisas de marketing podem ser desenvolvidas; seus requisitos necessários são considerados (como ferramentas, tecnologias e procedimentos de licenciamento) e o planejamento é executado (cronograma, orçamento, pessoas etc.) (CHANDLER, 2012). 
A produção engloba o desenvolvimento do jogo com a atuação de equipes técnicas de programação, arte, design de níveis e mecânicas (objetivos e formatos de jogo), além dos testes com pessoas da própria equipe ou potenciais jogadores.

Ao se produzir e testar a viabilidade do jogo, existe a fase de pós-produção que contempla o lançamento, que pode ser acompanhado por esforços de promoção, como publicidade paga ou relações públicas. Após esse período, as atenções voltam-se à manutenção do jogo e ao relacionamento com a comunidade.

Essas fases são posteriormente associadas às atividades de gestão de marketing para entendimento dos momentos mais críticos em relação à atuação do profissional responsável e à avaliação da forma como as empresas as conduzem.

Outros traços a serem avaliados a respeito da gestão da oferta são as prioridades de geração de receita, ou seja, as apostas que os empreendedores fazem para alavancarem seus negócios e gerarem receita sustentável (Quadro 7).

Quadro 7 - Apostas de geração de receita das empresas analisadas

\begin{tabular}{|c|c|c|c|}
\hline Empresa & Encomendas & $\begin{array}{c}\text { Busca por } \\
\text { publicadoras }\end{array}$ & $\begin{array}{c}\text { "Jogo dos } \\
\text { sonhos" }\end{array}$ \\
\hline 1 & Sim & Sim & Sim \\
\hline 2 & Sim & Não & Sim \\
\hline 3 & Não & Não & Não \\
\hline 4 & Sim & Sim & Não \\
\hline 5 & Sim & Sim & Sim \\
\hline 6 & Sim & Sim & Sim \\
\hline 7 & Sim & Sim & Não \\
\hline 8 & Não & Não & Não \\
\hline 9 & Sim & Sim & Não \\
\hline 10 & Sim & Sim & Sim \\
\hline 11 & Sim & Sim & Não \\
\hline 12 & Não & Não & Não \\
\hline
\end{tabular}

Fonte: Elaborado pelo autor, com base nos dados da pesquisa.

Todas as empresas que não foram consideradas outliers contam com jogos por encomenda como principal forma de geração de receita ou mesmo como forma de complementá-la. A terceirização de serviços é uma alternativa praticamente inevitável para sua sobrevivência.

A maioria das empresas também conta com a ajuda de publicadoras para executarem atividades de distribuição e de promoção dos jogos. Isso é importante, pois atividades de 
marketing geralmente são abarcadas por esse tipo de empresa e o que se pretendia era entender o nível de autonomia e de influência dos gestores em relação às decisões nessa área.

Em termos de apostas em um único jogo (“o jogo dos sonhos”) em oposição ou paralelamente ao desenvolvimento de vários jogos, encontrou-se um equilíbrio. Alguns entrevistados trabalhavam com um projeto principal e aceitavam encomendas para financiá-lo; outros tinham uma visão mais pragmática: desenvolviam vários jogos e protótipos e eliminavam aqueles que não cumpriam com as expectativas.

\subsection{GESTÃO DE MARKETING DAS EMPRESAS}

Notou-se, de forma geral, que o nível de conhecimento a respeito da gestão de marketing ainda era incipiente por parte das empresas dos entrevistados, mas algumas possuíam qualidades associadas às metodologias ágeis. Para elencar e descrever os principais desafios de marketing dessas empresas, foram analisadas com maior profundidade tanto a visão estratégica dos entrevistados quanto a gestão de marketing em termos tático e operacional, além das formas de inteligência de marketing.

\subsubsection{Visão Estratégica dos Entrevistados}

Dentre todas as palavras proferidas, frases e lógicas, há ideias centrais subjacentes que Bardin (2011) considera essenciais para o bom entendimento da forma estrutural e dos valores carregados pelos entrevistados - coisas que não foram ditas explicitamente, mas estão implícitas no conteúdo. Trata-se de uma análise transversal sintética que consiste em utilizar "tesoura" e "cola" para montar uma versão sintetizada do pensamento, a qual a autora compara com slogans publicitários.

Esse processo ocorre pela avaliação de diversos aspectos do texto, em especial das primeiras frases de cada resposta. Tendo isso em mente, é possível rotular entrevistados com base em sua forma estruturante de pensar. Esses "rótulos" ou slogans foram adaptados ao contexto em forma de 1 (um) parágrafo de texto artificial para cada entrevista, ou seja, não

proferido diretamente pelo entrevistado, mas resultante da análise transversal de todo o conteúdo realizada pelo autor.

Cada parágrafo do texto a seguir apresentado no Quadro 8 representa a visão estratégica do entrevistado em uma forma condensada que servirá como ponto de partida de análise da gestão de marketing realizada nessas empresas. Seria como se perguntássemos ao entrevistado: 
Qual o resumo de tudo o que você disse? Essa questão não foi formulada diretamente aos entrevistados, pois, conforme Bardin (BARDIN, 2011, p. 98) ressalta, é função do analista avaliar e resumir o conteúdo com perguntas auxiliares como: “O que essa pessoa está dizendo realmente? Como isso é dito? Que poderia ela ter dito diferentemente? O que ela não disse? Que diz sem o dizer? Qual é a lógica discursiva do conjunto?”, entre outras.

Com base nos parágrafos-resumo (Quadro 8), foi possível recorrer a múltiplas perspectivas de análise pela variedade dos focos e dos temas ressaltados pelos entrevistados. Para tornar a análise produtiva, foram extraídas do texto 6 (seis) perspectivas de análise, consideradas aderentes aos objetivos de pesquisa. São elas:

\section{i) Entendimento geral de marketing}

Dentre os entrevistados, emergiu um baixo para médio padrão de nível de conhecimento sobre marketing e seu papel na organização, que pode ser expresso pelas ideias de que "marketing é um mal necessário" (Entrevistado 11) ou que "precisamos trabalhar em jogos com marketing agressivo como os hiper casuais" (Entrevistado 7). Essas ideias tendem a representar uma visão de escopo limitado às atividades de um único ' $\mathrm{P}$ ' do mix de marketing: o ' $\mathrm{P}$ ' de promoção (KOTLER; ARMSTRONG, 2007). É como se o único papel do marketing fosse o convencimento, a persuasão do público para um jogo que não precisa ter uma qualidade satisfatória ('P' de produto), uma estratégia clara de precificação ('P' de preço) ou uma coordenação entre plataformas, lojas e canais de distribuição do mesmo ('P' de praça ou de ponto de venda) (KOTLER; ARMSTRONG, 2007).

Isso pode também ser visto como um foco em estratégias de marketing do tipo push (“empurrar"), que se traduz em práticas de vendas, muitas vezes invasivas, dedicadas à produção e ao escoamento do jogo no mercado consumidor. O movimento contrário seria uma estratégia do tipo pull ("puxar”), que identifica um potencial público consumidor e trabalha com a disponibilização intensiva de informações para atraí-los para os canais de distribuição mais adequados (BROCATO, 2010).

Esse nível de conhecimento acerca do papel do marketing não chega a ser novidade, visto que os líderes dessas empresas geralmente não foram acadêmica ou mercadologicamente preparados para serem gestores de marketing. A quebra incisiva desse padrão partiu da Empresa 8, que possui um CEO pós-graduado em Comunicação e Marketing. 
Quadro 8 - Resultados da análise transversal sintética do conteúdo

\begin{tabular}{|c|c|c|}
\hline \multicolumn{2}{|c|}{ Entrevistado } & \multirow{2}{*}{$\begin{array}{l}\text { Parágrafo-resumo } \\
\text { Mergulhei de cabeça nesse mercado. Estou tentando a sorte. É difícil. Pode dar errado, mas procuro ser flexível, um dia de cada vez, e } \\
\text { quem sabe lançaremos com uma grande publisher um jogo de grande sucesso. }\end{array}$} \\
\hline 1 & $\begin{array}{l}\text { CEO, } 33 \text { anos } \\
\text { Micro empresa }\end{array}$ & \\
\hline 2 & $\begin{array}{l}\text { CEO, } 32 \text { anos } \\
\text { Pequena empresa }\end{array}$ & $\begin{array}{l}\text { Faço um jogo para durar. Invisto muito nas pessoas e sou otimista em relação ao futuro da empresa. Ainda assim, temos muito que evoluir } \\
\text { em termos de marketing e de análises de dados. }\end{array}$ \\
\hline $3 *$ & $\begin{array}{l}\text { Produtor Executivo, } 32 \text { anos } \\
\text { Média empresa }\end{array}$ & $\begin{array}{l}\text { Nós amamos o que fazemos, mas exigimos lucro. Se uma ideia não vai para a frente, iremos cortá-la. E temos processos muito bem } \\
\text { estruturados para assegurar isso. Ainda assim, temos muito que evoluir em termos de CRM e de gestão de comunidades. }\end{array}$ \\
\hline 4 & $\begin{array}{l}\text { Diretor de Produtos, } 40 \text { anos } \\
\text { Micro empresa }\end{array}$ & $\begin{array}{l}\text { Videogames são o futuro e acreditamos que irão se integrar a diversas indústrias (como estamos fazendo com a indústria da educação). } \\
\text { Estamos vivendo um dia de cada vez, tentando e errando, com muito para estruturar e profissionalizar. }\end{array}$ \\
\hline 5 & $\begin{array}{l}\text { Diretor de Marketing e } \\
\text { Experiência do Usuário, } 30 \text { anos } \\
\text { Micro empresa }\end{array}$ & $\begin{array}{l}\text { Focamos em produtos de qualidade e queremos o suporte de uma publicadora com as questões de mercado. Precisamos de mais fontes de } \\
\text { investimento para conseguirmos mais times especializados que deem mais atenção à nossa comunidade de players e que tragam mais } \\
\text { insights a partir de dados. }\end{array}$ \\
\hline 6 & $\begin{array}{l}\text { CEO, } 32 \text { anos } \\
\text { Pequena empresa }\end{array}$ & $\begin{array}{l}\text { Tratamos nossos funcionários como parte da família e é por isso que estamos crescendo apesar do mercado brasileiro ser difícil. Encaramos } \\
\text { o jogo como um serviço, sempre em desenvolvimento de acordo com o feedback dos nossos usuários. Poderíamos ter pessoas } \\
\text { especializadas em dados para evoluir ainda mais e ter uma filial no exterior para facilitar as negociações. }\end{array}$ \\
\hline 7 & $\begin{array}{l}\text { CEO, } 32 \text { anos } \\
\text { Pequena empresa }\end{array}$ & $\begin{array}{l}\text { Não gostamos de marketing, gostamos de fazer jogos. Mas, antes de fazermos os nossos grandes jogos, nossas grandes ideias, precisamos } \\
\text { sobreviver. Para isso, precisamos trabalhar com encomendas e jogos "agressivos" em marketing (como os hiper casuais) para gerarmos } \\
\text { renda e nos dar a tranquilidade para num futuro trabalharmos em nossas próprias ideias. }\end{array}$ \\
\hline $8 * *$ & $\begin{array}{l}\text { CEO, } 27 \text { anos } \\
\text { Pequena empresa }\end{array}$ & $\begin{array}{l}\text { Eu não foco no jogo, mas na minha comunidade. Eu quero que as pessoas reflitam sobre temas sociais importantes. E por isso vou criando } \\
\text { e publicando jogos o mais rápido que posso, para errar rápido e aprender rápido também. Quero no futuro continuar entendendo mais meu } \\
\text { público por meio de dados e continuar atendendo às suas necessidades. }\end{array}$ \\
\hline 9 & $\begin{array}{l}\text { CEO, } 24 \text { anos } \\
\text { Micro empresa }\end{array}$ & $\begin{array}{l}\text { Estamos trabalhando sob encomenda para gerarmos renda e conseguirmos desenvolver nosso jogo autoral. Temos o sonho de ter um jogo } \\
\text { grande e de contar com uma publisher para cuidar dos assuntos relacionados a marketing. Seria interessante também contarmos com um } \\
\text { gestor de comunidades para se relacionar com os players da nossa base. }\end{array}$ \\
\hline 10 & $\begin{array}{l}\text { CEO, } 35 \text { anos } \\
\text { Micro empresa }\end{array}$ & $\begin{array}{l}\text { Queremos ser uma empresa de jogos autorais, mas por enquanto precisamos sobreviver. Aceitamos trabalhos sob encomenda, participamos } \\
\text { de editais e pensamos em parcerias com publishers. Não temos ninguém que entenda de marketing e o ideal seria que uma publisher fizesse } \\
\text { esse trabalho por nós. }\end{array}$ \\
\hline 11 & \begin{tabular}{|l|} 
CEO, 29 anos \\
Pequena empresa
\end{tabular} & $\begin{array}{l}\text { Eu não quero que meu jogo seja um serviço de uma startup que quer fazer muito dinheiro com ele. Eu quero criar uma obra marcante, que } \\
\text { seja reconhecida por sua qualidade. Marketing é um mal necessário, mas será a publisher que cuidará disso. }\end{array}$ \\
\hline $12 *$ & $\begin{array}{l}\text { Diret. de Aquisição de Usuários, } \\
36 \text { anos } \\
\text { Grande empresa }\end{array}$ & $\begin{array}{l}\text { Para nós o que importa é a margem bruta. Não olhamos um público e direcionamos nossos esforços ao mesmo. Verificamos entre todos os } \\
\text { públicos quais são os mais rentáveis e não o contrário. Essa indústria não se trata necessariamente de ser a mais criativa, mas de ter capital } \\
\text { para bancar os testes, ter processos, uma boa equipe e acreditar em princípios, mesmo "quebrando a cara" algumas vezes. }\end{array}$ \\
\hline
\end{tabular}

***epresentante de empresa considerada outlier em função de sua finalidade.

Fonte: Elaborado pelo autor, com base nos dados da pesquisa. 
A Empresa 8 trabalha com jogos dedicados ao entretenimento adulto, tendo como público-alvo a comunidade LGBT. Seu CEO afirma que o foco está na construção de uma comunidade forte ('P' de Pessoas) e de uma marca que tem como missão conseguir o maior portfólio do mundo de jogos para esse público, com o intuito de informar e de incentivar a reflexão (forte posicionamento). A clareza com que as bases de valor de seus jogos estão definidas permite a ampliação do escopo de marketing na organização, estando de acordo com os pensamentos mais modernos na área.

As Empresas 3 e 12, ambas outliers, também apresentam maior maturidade em gestão de marketing por conta de seu porte, permitindo que uma parte da mão de obra seja exclusivamente dedicada a tais atividades. Mesmo assim, o que se nota, ao contrário da Empresa 8, é uma orientação muito mais empenhada no retorno financeiro do que na construção de uma marca com um propósito, atributos de imagem e de missão bem definidos: "para nós o que é importa é a margem bruta... Verificamos entre todos os públicos quais são os mais rentáveis e não o contrário" (Entrevistado 12).

ii) Obra versus mercadoria

Observou-se uma dualidade de visões no que diz respeito à oferta, que pode ser tratada pelos desenvolvedores sob uma perspectiva artística ou mercadológica. Se a perspectiva for puramente artística, há pouco espaço para práticas de marketing como segmentação, pesquisa de mercado e adaptação da oferta de acordo com os interesses da demanda, pois é um modelo de produção que acontece de dentro para fora, ou seja, é uma expressão criativa do desenvolvedor, que manifesta seus sentimentos e suas ambições artísticas, pouco importando a opinião ou as expectativas do mercado.

Essa perspectiva pode ser entendida como "miopia de marketing" (LEVITT, 1984), mas é preciso tomar cuidado para não realizar um julgamento simplista da estratégia de um desenvolvedor, caso ele, de fato, não possua nenhuma pretensão mercadológica como vender muitas unidades, aumentar a receita da empresa, atender a um nicho de mercado etc. Se há uma ou mais expectativas de desempenho mercadológico, a flexibilidade e a adaptação aparentam ser os caminhos mais seguros para o sucesso.

Do outro lado do espectro, a oferta pode ser entendida sob uma perspectiva puramente mercadológica, o que abre espaço para uma série de possibilidades para a atuação do marketing. Como é um modelo de produção que acontece de fora para dentro, é possível atacar as necessidades do mercado e de públicos específicos, entendendo com mais clareza suas 
características, necessidades e desejos. No entanto, uma visão totalmente mercadológica pode ser corrosiva em longo prazo, pois as soluções mais criativas, inesperadas e inspiradas dos desenvolvedores vão muito além das análises de público e de mercado. Principalmente nessa indústria, na qual a criatividade é a matéria-prima, pode ser danoso para a empresa em médio e longo prazo deixar de surpreender e de arriscar, com novos conceitos artísticos e estéticos, frutos da imaginação, inspiração e experiências pessoais de seus desenvolvedores.

De forma geral, notou-se certo equilíbrio no conteúdo das entrevistas entre esses dois polos, com alguns casos de tendências mais artísticas - "eu não quero que meu jogo seja um serviço de uma startup que quer fazer muito dinheiro com ele" (Entrevistado 11) e outros, de tendências mais mercadológicas - "encaramos o jogo como um serviço, sempre em desenvolvimento de acordo com o feedback dos nossos usuários" (Entrevistado 6). As demais micro e pequenas empresas tendem a se situar em posições intermediárias.

Com isso, o que se pode concluir é que, a partir do momento em que a empresa possui alguma ambição mercadológica, deve haver espaço para uma visão estratégica de marketing que irá justamente ajudar a cumprir tais objetivos. As Empresas outliers 3 e 12 podem servir como modelo de sucesso, caso o objetivo seja superar as barreiras de faturamento de micro e pequenas empresas, partindo para "os próximos níveis" (média e grande empresa), mas, mesmo assim, a natureza criativa da oferta não pode ser deixada de lado. O equilíbrio entre esses dois polos e o entendimento das possibilidades e das limitações do marketing devem ser considerados.

iii) Análise de dados

Observou-se, entre os entrevistados, grande valorização das atividades relacionadas tanto com a análise de dados quanto com os objetivos como: aumento do engajamento, coleta de feedbacks, relacionamento e diminuição da desistência dos jogadores. Uma vez que o marketing é entendido naturalmente como sinônimo de promoção, a análise de dados e o relacionamento com os jogadores parecem ser, muitas vezes, vistos como atividades à parte.

Há certo consenso a respeito da importância e, ao mesmo tempo, da dificuldade de execução ou de obtenção dos recursos disponíveis para a realização da análise de dados. O relato a seguir resume bem essa percepção geral: "Precisamos de mais fontes de investimento para conseguirmos mais times especializados que deem mais atenção à nossa comunidade de players e que tragam mais insights a partir de dados" (Entrevistado 5). 
A impossibilidade de se realizar análises de dados efetivas é atribuída à falta de conhecimento e de maturidade atuais que, segundo os entrevistados, podem ser supridas pelo aumento do quadro de colaboradores especializados, dedicados exclusivamente a esse tipo de atividade.

Mais especificamente, mencionou-se o cargo de Gestor de Comunidades, referindo-se ao profissional responsável por estabelecer uma ponte entre a empresa e os jogadores, com o objetivo final de criar jogos melhores para todos (DEALESSANDRI, 2020). Esse seria o profissional responsável não só pelo relacionamento com os jogadores (usuários ou clientes finais), mas também pela coleta e análise de dados, gerando ideias de incremento dos jogos em atualizações ou novas criações.

No entanto, há duas questões que precisam ser levadas em consideração: a primeira, o escopo desse profissional; e a segunda, a capacidade real de micro e pequenas empresas contratarem esse tipo de mão de obra. Segundo Dealessandri (2020), formações que habilitam o profissional nas áreas de comunicação e de mídias sociais dão passaporte quase que imediato à função, ou seja, sua capacidade de tratar e de analisar dados pode não ser a mais adequada, pois seu escopo será outro (questão 1). Isso demanda a existência de profissionais mais especializados (como estatísticos ou cientistas de dados) para darem suporte aos objetivos e às metas desse profissional - o que aumenta ainda mais a dificuldade de contratação para micro e pequenas empresas (questão 2).

Entende-se, portanto, a existência de um desencontro entre as necessidades das empresas analisadas e sua real capacidade de implementação de processos de inteligência e de análise de dados mais robustos para incremento da performance mercadológica dos jogos.

\section{iv) Retorno financeiro}

A escassez de recursos financeiros é uma constante nessas empresas, sendo uma barreira para a necessidade de maiores investimentos em áreas-chave, incluindo marketing.

Isso posto, haverá sempre necessidade de buscar fontes de renda, mesmo que representem algum desvio nos planos iniciais: “(...) antes de fazer os nossos grandes jogos, nossas grandes ideias, precisamos sobreviver. Para isso, precisamos trabalhar com encomendas (...)" (Entrevistado 7). Nesse sentido, existe uma mentalidade mais conectada com a realidade, o que de fato permitiu a sobrevivência mínima de 3 (três) anos de cada uma dessas empresas.

As expectativas sobre o retorno financeiro a partir de atividades de marketing devem estar calibradas junto à realidade dessas empresas. Não adianta, por exemplo, direcionar 
recursos de marketing a projetos autorais que podem não apresentar retorno financeiro suficientemente rápido para equilibrar o fluxo de caixa.

Sendo assim, parece ser razoável apostar em uma gestão de marketing mais atrelada à performance e à geração de resultados mais práticos e visíveis em curto prazo do que em ações de longos períodos de investimentos e de recursos (um complexo e abrangente plano de mídia, por exemplo).

v) Papel de produção e publicação (publishers)

As empresas que geralmente produzem e publicam os jogos (chamadas pelos entrevistados de publishers ou publicadoras) apresentam-se como alternativas de superação às dificuldades financeiras impostas e de suprimento às atividades de marketing. Tratam-se de empresas que geralmente dão suporte financeiro para o desenvolvimento de jogos e ficam responsáveis pela comunicação e pelo escoamento do produto no mercado (SCREEN SKILLS, 2020), gerenciando as atividades típicas de marketing correspondentes à promoção e à distribuição, em troca de alguma participação nos lucros sobre a venda dos jogos por conta da divisão dos riscos no lançamento.

As publicadoras são vistas de forma positiva pela maioria dos entrevistados e como importantes parceiras na busca de um lançamento de sucesso. Muitas vezes, é a parte mais competente e mais especializada em marketing, contando com a total confiança dos desenvolvedores entrevistados: "não temos ninguém que entenda de marketing e o ideal seria que uma publisher fizesse esse trabalho por nós” (Entrevistado 10).

O que se observou, a partir deste ponto de vista, foi uma evidente lacuna de conhecimento a respeito das atividades de marketing não atreladas aos 'Ps' de promoção: o propósito de marca, o posicionamento e o público-alvo dos jogos foram itens que precisariam ser definidos ainda na fase de planejamento do jogo a ser desenvolvido e que seriam posteriormente apresentados a uma publicadora como instrumento de persuasão para captação de recursos. Ou seja, a gestão de marketing é necessária em vários momentos, incluindo aqueles em que a publicadora não está disponível. 
vi) Mentalidade empreendedora

Observou-se muita esperança e confiança na fala dos entrevistados em relação ao negócio que administram ao mesmo tempo em que houve reconhecimento das dificuldades e dos obstáculos a serem enfrentados: "mergulhei de cabeça nesse mercado. Estou tentando a sorte. É difícil... pode dar errado, mas procuro ser flexível... um dia de cada vez” (Entrevistado 1).

É arriscado manter-se ativo nesse segmento, mas os entrevistados equilibram-se com ousadia e, ao mesmo tempo, com cautela. Não foram observadas visões ingênuas como "vai dar tudo certo", mas também não foram observadas visões altamente pessimistas como "vai dar tudo errado". É como se cada fracasso fosse enxergado como mais um degrau de aprendizado em uma grande escada rumo ao sucesso, o que é uma mentalidade tipicamente empreendedora (HISRICH; PETERS; SHEPERD, 2014).

Se nas micro e pequenas empresas observou-se essa mentalidade mais empreendedora, na média e na grande empresa, notou-se, naturalmente, uma mentalidade mais administrativa (o que pode ser explicado, inclusive, pela posição dos entrevistados, que não eram sóciosfundadores), o que condiciona a inovação aos recursos disponíveis e não o contrário: "essa indústria não se trata necessariamente de ser o mais criativo, mas de ter capital para bancar os testes, ter processos, uma boa equipe e acreditar em princípios..." (Entrevistado 12).

\subsubsection{Diagnóstico da Gestão}

Em um primeiro momento, realizou-se a contagem de termos-chave de todas as entrevistas transcritas para avaliação preliminar do conteúdo a ser codificado por sua estrutura temática, o que viabilizaria a avaliação da gestão de marketing. Os resultados dessa consulta apresentam-se na Figura 23 a seguir. 
Figura 23 - Nuvem de palavras com termos-chave de todo o conteúdo transcrito ${ }^{64}$

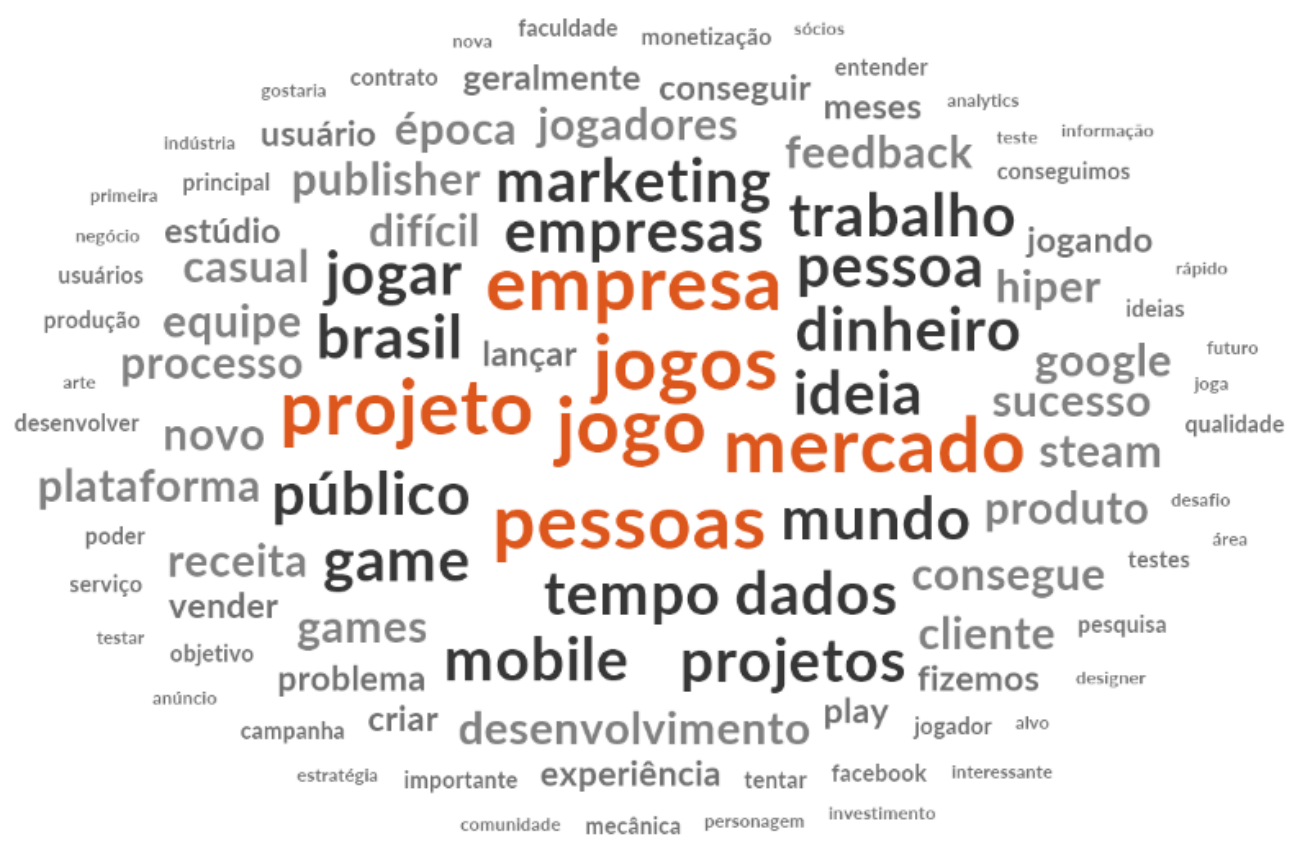

Fonte: Elaborada pelo autor, com base nos dados da pesquisa e com o uso da ferramenta NVivo.

As palavras "jogos", "jogo" e "projeto" foram as mais mencionadas por se tratar da principal oferta ${ }^{65}$ em questão. A palavra "empresa" denota a responsável pelo desenvolvimento do jogo e as "empresas" são as concorrentes, as parceiras e outros participantes do ecossistema (“mercado").

O que de fato chama a atenção é a presença de palavras como "pessoas" e "pessoa", que são os protagonistas do conteúdo e da narrativa dos entrevistados. Quando mencionadas, geralmente, dizem respeito aos colaboradores da organização (sendo "equipe" uma palavra equivalente) e aos jogadores (sendo "público” uma palavra equivalente).

Por ser um produto altamente dependente da criatividade e que só pode ter como fonte as próprias pessoas, estabeleceu-se que a segmentação do texto iria separar categoricamente os dois principais tipos de pessoas presentes no conteúdo: atribuiu-se, portanto, o código player para designar as pessoas pertencentes ao público consumidor dessas empresas e o código pessoas para designar os colaboradores e outras pessoas direta ou indiretamente envolvidas no desenvolvimento dos jogos. Além disso, identificou-se os "players" em três estágios distintos na jornada de consumo, que se transformaram em subcódigos: Identificação (não se sabe onde

\footnotetext{
${ }^{64}$ O NVivo elimina automaticamente stopping words (palavras conectoras como "e", "para", "se"). O software possui uma extensão automática em fase de testes para a língua portuguesa brasileira, que ainda demanda correções de usuários humanos. A nuvem também foi manualmente configurada para se limitar a no máximo 1000 palavras com o mínimo de 4 caracteres cada. Essa configuração trouxe resultados mais produtivos para a análise.

${ }^{65}$ A oferta é um jogo que, a princípio, é um projeto.
} 
estão e quais são suas características), Atração (já se sabe onde estão, mas ainda não consomem os produtos) e Engajamento (já consomem os produtos e é desejável que permaneçam em contato).

O mesmo processo ocorre com os temas Mercado (com subtemas - ou subcódigos: Tendências, Outras empresas, Outros Jogos), Praça (que inclui o subcódigo Plataformas para se referir a jogos cujo descritor Mobile também foi bastante frequente), entre outros temas elencados na Tabela 2.

Todo o conteúdo relacionado com os aspectos da gestão de marketing das empresas foi segmentado, atribuindo-se códigos a partes do texto relacionadas a um tema específico. Essa codificação é, em boa medida, similar à estrutura temática do roteiro, mas, pela imprevisibilidade das respostas dos entrevistados, foram necessários alguns ajustes, especialmente ao serem gerados os subtemas.

A Tabela 2 mostra a relação de temas e subtemas convertidos em códigos para segmentar o conteúdo analisado em uma ordenação por volume percentual de palavras utilizadas (do maior para o menor). A coluna "Entrevistas" mostra a quantidade de entrevistados que citaram os códigos gerados. Por exemplo: 11 entrevistados mencionaram pelo menos um segmento de texto codificado por "Orientação ao mercado", enquanto somente 2 entrevistados comentaram ao menos um segmento de texto Orientação mista. Ao final, o código Produto, como um todo, permeou as menções de todos os 12 entrevistados (mantendo-se os códigos exclusivos).

Os segmentos de texto codificados são chamados "Referências", cuja quantidade tende a estar altamente correlacionada com a quantidade de "Palavras" pertencentes a cada código e subcódigo (Correlação de Pearson ${ }^{66}=0,997$ aplicada nos dados das colunas 3 e 4 da Tabela 2). Esses números refletem a abrangência dos códigos no conteúdo e dão uma boa noção da representatividade temática no discurso dos entrevistados, sendo a coluna "Volume \%" (de palavras) uma boa variável de descrição dessa proporção tanto de palavras quanto de referências.

Assuntos relacionados ao "Player" foram os mais frequentes entre os entrevistados $32,43 \%$ do volume de palavras registradas estava diretamente atrelado a esse tema (quase 1/3 do total de assuntos). Os subtemas Engajamento e Atração juntos permearam $81 \%$ do tema

\footnotetext{
${ }^{66} \mathrm{O}$ coeficiente de correlação de Pearson é utilizado para verificar o nível de associação entre duas variáveis de forma linear, variando entre -1 (máxima correlação negativa) e 1 (máxima correlação positiva). No caso, a quantidade de referências e palavras estão positiva e altamente correlacionadas $(0,997)$. Maiores detalhes em BUSSAB; MORETTIN. Estatística Básica. São Paulo: Saraiva, 2010.
} 
Player, deixando os 19\% restantes para o subtema Identificação" (direta - quando o desenvolvedor proativamente procura delinear seu público; ou indireta - quando o desenvolvedor "descobre" seu público depois de lançar o jogo).

Tabela 2 - Volumetria da segmentação temática do conteúdo de gestão de marketing

\begin{tabular}{|c|c|c|c|c|}
\hline $\begin{array}{l}\text { Códigos (temas) } \\
\text { Subcódigos (subtemas) }\end{array}$ & Entrevistas & Referências & Palavras & Volume \% \\
\hline Player & 11 & 105 & 14622 & $32,43 \%$ \\
\hline Engajamento & 11 & 45 & 6501 & $44,46 \%$ \\
\hline Atração & 10 & 40 & 5351 & $36,60 \%$ \\
\hline Identificação indireta & 9 & 13 & 1609 & $11,00 \%$ \\
\hline Identificação direta & 5 & 7 & 1161 & $7,94 \%$ \\
\hline Produto & 11 & 64 & 9247 & $20,51 \%$ \\
\hline Orientação ao mercado & 11 & 39 & 4920 & $53,21 \%$ \\
\hline Orientação ao produto & 7 & 23 & 3979 & $43,03 \%$ \\
\hline Orientação mista & 2 & 2 & 348 & $3,76 \%$ \\
\hline Promoção & 8 & 41 & 4877 & $10,82 \%$ \\
\hline Anúncios pagos & 8 & 17 & 1874 & $38,43 \%$ \\
\hline Relações Públicas/Mídia não paga & 7 & 9 & 1361 & $27,91 \%$ \\
\hline Planejamento & 8 & 9 & 1256 & $25,75 \%$ \\
\hline Agências & 3 & 4 & 294 & $6,03 \%$ \\
\hline Formatos & 2 & 2 & 92 & $1,89 \%$ \\
\hline Pessoas & 12 & 40 & 3909 & $8,67 \%$ \\
\hline Papéis e funções & 12 & 40 & 3909 & $100,00 \%$ \\
\hline Processos & 7 & 29 & 3460 & $7,67 \%$ \\
\hline Publisher & 7 & 20 & 2501 & $72,28 \%$ \\
\hline Encomenda & 2 & 7 & 636 & $18,38 \%$ \\
\hline Self-Publishing & 2 & 2 & 323 & $9,34 \%$ \\
\hline Praça & 5 & 31 & 3062 & $6,79 \%$ \\
\hline Localização geográfica & 4 & 10 & 812 & $26,52 \%$ \\
\hline Lojas Online & 5 & 8 & 845 & $27,60 \%$ \\
\hline Plataformas & 5 & 13 & 1405 & $45,89 \%$ \\
\hline Preço & 9 & 34 & 2927 & $6,49 \%$ \\
\hline Formas de Monetização & 9 & 23 & 1555 & $53,13 \%$ \\
\hline Estratégia de Monetização & 7 & 10 & 1338 & $45,71 \%$ \\
\hline $\begin{array}{l}\text { Contratação Business to Business- } \\
\text { B2B }\end{array}$ & 1 & 1 & 34 & $1,16 \%$ \\
\hline Branding & 3 & 15 & 1685 & $3,74 \%$ \\
\hline Posicionamento artístico & 3 & 9 & 810 & $48,07 \%$ \\
\hline Posicionamento social & 1 & 5 & 792 & $47,00 \%$ \\
\hline Posicionamento mercadológico & 1 & 1 & 83 & $4,93 \%$ \\
\hline Mercado & 3 & 11 & 1302 & $2,89 \%$ \\
\hline Outros jogos & 2 & 5 & 553 & $42,47 \%$ \\
\hline Tendências & 3 & 4 & 520 & $39,94 \%$ \\
\hline Outras empresas & 2 & 2 & 229 & $17,59 \%$ \\
\hline Total Geral & 12 & 370 & 45091 & $100,00 \%$ \\
\hline
\end{tabular}

Fonte: Elaborada pelo autor, com base nos dados da pesquisa e com o uso da ferramenta NVivo. 
Pela densidade de conteúdos relacionados, o engajamento e a atração de Players, os conteúdos atrelados ao Produto, à Promoção, às Pessoas e aos Processos somam aproximadamente $80 \%$ de todo o conteúdo gerado.

Mesmo assim, o volume por si só faz uma correspondência com a importância que os próprios entrevistados atribuíram a cada um dos assuntos, pois foram os mais citados. De forma objetiva, é preciso se atentar também àquilo que é pouco ou em nenhum momento mencionado, como sugere Bardin (2011).

A pouca exploração da temática "Mercado" (2,89\% do volume de palavras) pode sugerir uma orientação de "dentro para fora" e não "de fora para dentro", como se espera da atuação mais moderna de marketing. No entanto, a baixa incidência da temática "Branding" (3,74\% do volume de palavras) pode sinalizar um desconhecimento das práticas ou da importância da gestão da marca e, quando ocorreu (em apenas três entrevistas), os únicos subtemas que emergiram foram os atrelados ao posicionamento.

Mas, antes de se aprofundar nas temáticas, foi necessário a resolução de dois problemas: o primeiro, foi separar as empresas outliers em conteúdo das empresas regulares; e o segundo, localizar cada tema e subtema de gestão de marketing entre as diferentes fases do processo de produção.

Para a resolução do primeiro problema, realizou-se uma análise de clusters para dar subsídios de avaliação das diferenças entre o conteúdo das entrevistas, unindo-a com as análises descritivas anteriormente realizadas, que já apontavam as Empresas 3 e 12 como outliers por conta de seu porte frente às demais.

A partir do dendrograma gerado pela análise de clusters (Figura 24), foi possível constatar a formação de grupos de entrevistas por maior homogeneidade (como as entrevistas 10 e 11) e por maior heterogeneidade (como as entrevistas 8 e 6) em relação ao conteúdo. Entre esses extremos, há a formação de "galhos" que se separam do "tronco" principal e que dão origem a "ramos" com uma ou mais entrevistas.

Pela baixa quantidade de itens avaliados (12 entrevistas, incluindo as Empresas 3 e 12 já consideradas outliers em função de seu porte), optou-se pela delimitação de grupos até o terceiro "galho", sendo o primeiro composto pelo Entrevistado 8; o segundo, pelo Entrevistado 12; e o terceiro, por todos os outros entrevistados. Há o reconhecimento das similaridades entre 2 ou 3 empresas isoladamente, como as empresas 10 e 11, mas não competirá ao presente trabalho elucidá-las em prol de uma análise que procura a emergência de padrões gerais de desafios a serem superados. 
Figura 24 - Dendrograma da análise de cluster por similaridade de palavras ${ }^{67}$

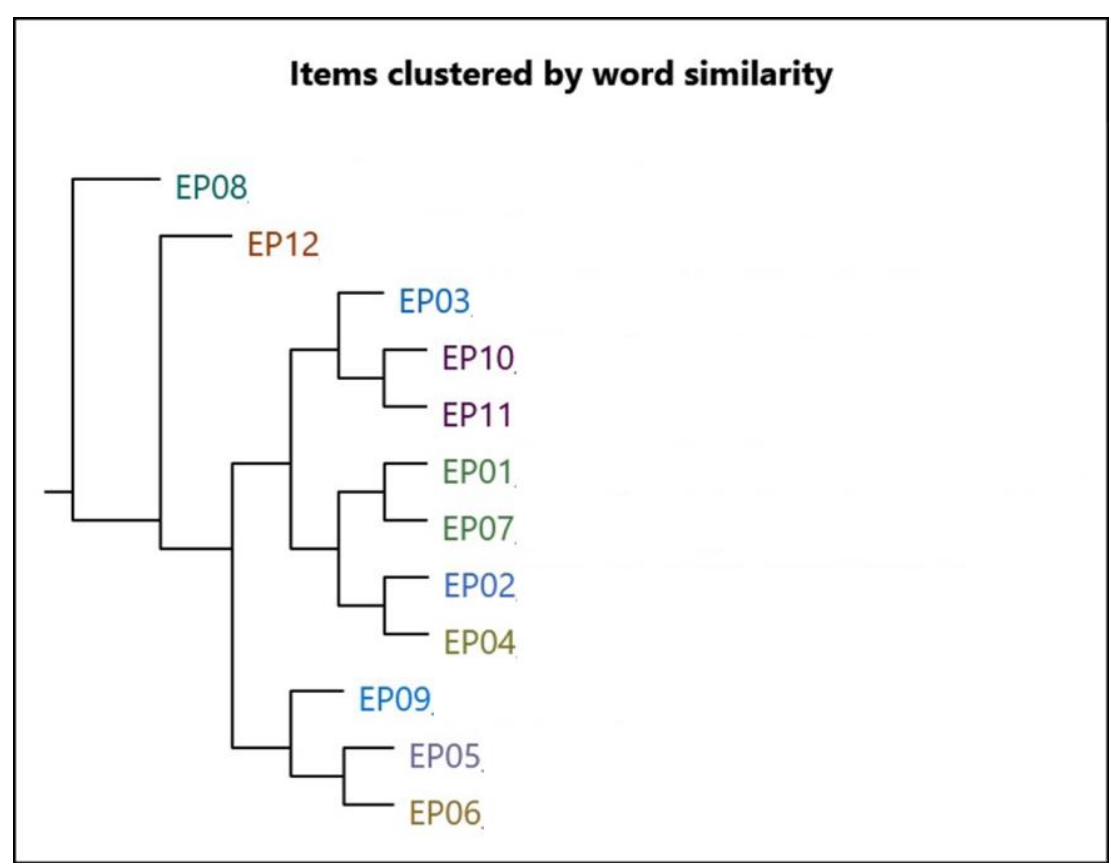

Fonte: Saída do programa com o uso da ferramenta NVivo.

O entrevistado 12 é, portanto, um outlier em função do porte da empresa e do conteúdo da entrevista. O entrevistado 3 é um outlier somente em função do porte, mas também terá seu conteúdo avaliado à parte por conta de seu momento atual e das especificidades não capturadas pela ferramenta de análise, a serem elucidadas nas próximas seções. $\mathrm{O}$ entrevistado 8 também é um outlier em função da finalidade da empresa e do conteúdo da entrevista que sinaliza uma potencial maturidade em gestão de marketing. Essas foram, portanto, empresas avaliadas à parte e que serviram de base de comparação em momentos específicos da análise do diagnóstico da gestão de marketing.

Para a resolução do segundo problema, criou-se uma categoria de codificação denominada "Fases de desenvolvimento". O conteúdo contou, portanto, com uma segunda camada de codificação sobreposta à codificação de temática de gestão de marketing, possibilitando cruzamentos como o realizado na Tabela 3 a seguir.

${ }^{67} \mathrm{EP}=$ Entrevista em profundidade. Exemplo: EP08 = Entrevista em profundidade com o Entrevistado 8, da Empresa 8. 
Tabela 3 - Temas mais abordados em gestão de marketing ao longo das fases de desenvolvimento**

\begin{tabular}{|c|c|c|c|c|c|c|c|c|}
\hline Gestão de marketing & & & & es de de & senvolvim & iento & & \\
\hline Temas & 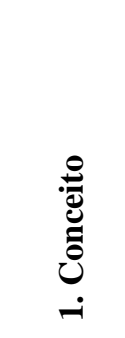 & 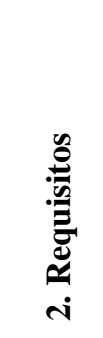 & 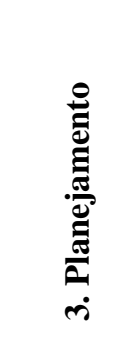 & 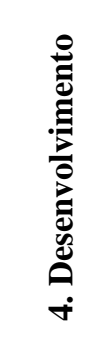 & 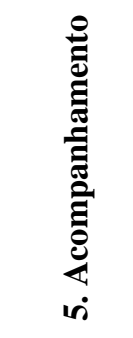 & 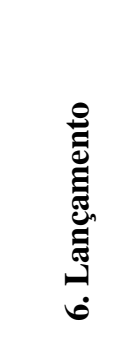 & 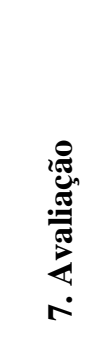 & 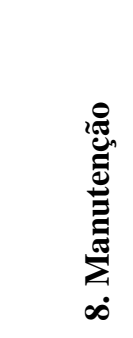 \\
\hline Player & $9,6 \% *$ & - & $0,5 \%$ & $0,1 \%$ & $3,5 \%$ & $1,1 \%$ & $2,9 \%$ & $14,8 \% *$ \\
\hline Produto & $8,5 \% *$ & - & $2,2 \%$ & $1,3 \%$ & $\mathbf{7 , 5 \% *}$ & - & $0,4 \%$ & $0,7 \%$ \\
\hline Promoção & - & - & $0,3 \%$ & - & - & $9,3 \% *$ & $1,3 \%$ & - \\
\hline Pessoas & $2,0 \%$ & $1,0 \%$ & $1,1 \%$ & $2,3 \%$ & - & - & - & $2,3 \%$ \\
\hline Processos & $1,6 \%$ & $0,2 \%$ & $0,5 \%$ & $1,1 \%$ & $0,6 \%$ & $2,0 \%$ & $1,1 \%$ & $0,7 \%$ \\
\hline Praça & $0,7 \%$ & $1,0 \%$ & $1,2 \%$ & $0,2 \%$ & - & $0,8 \%$ & $1,5 \%$ & $1,3 \%$ \\
\hline Preço & - & - & $5,1 \% *$ & - & - & $0,2 \%$ & - & $1,2 \%$ \\
\hline Branding & $2,1 \%$ & - & $0,5 \%$ & - & - & $0,5 \%$ & $0,5 \%$ & - \\
\hline Mercado & $2,3 \%$ & $0,6 \%$ & - & - & - & - & - & - \\
\hline
\end{tabular}

A Tabela 4 apresenta a distribuição do conteúdo codificado das entrevistas somando $100 \%$. Essa distribuição faz uma ponderação com o volume de conteúdo de cada tema de marketing, possibilitando uma visualização da concentração de conteúdo em determinados cruzamentos.

Por serem 72 cruzamentos temáticos ( 9 temas x 8 fases de desenvolvimento), optou-se pela priorização daqueles que apresentam maior volume de conteúdo, partindo-se do pressuposto que são momentos-chave da gestão de marketing, sob o ponto de vista dos entrevistados (valores em destaque). Além disso, os cruzamentos com valores nulos ou muito baixos também foram considerados na análise, visto que poderiam indicar pontos cegos de gestão, falta de conhecimento ou subestimação de fatores que poderiam alavancar o negócio. 
Tabela 4 - Subtemas mais abordados em gestão de marketing ao longo das fases de desenvolvimento**

\begin{tabular}{|c|c|c|c|c|c|c|c|c|c|}
\hline \multirow[b]{2}{*}{ Temas } & \multirow[t]{2}{*}{ Gestão de Marketing } & \multicolumn{8}{|c|}{ Fases de desenvolvimento } \\
\hline & & 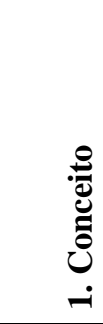 & 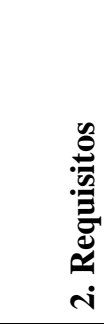 & 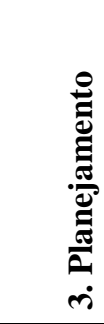 & 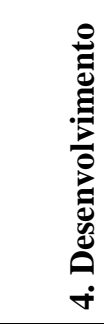 & 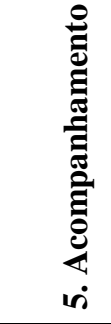 & 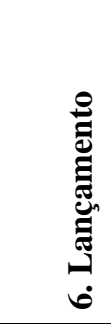 & 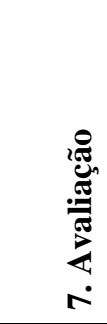 & $\sum_{\infty}$ \\
\hline \multirow{4}{*}{ 卷 } & Atração & $2,3 \%$ & - & $0,5 \%$ & - & $3,5 \%$ & $0,5 \%$ & $1,3 \%$ & $1,6 \%$ \\
\hline & Engajamento & $0,1 \%$ & - & - & $0,1 \%$ & - & $0,6 \%$ & $1,5 \%$ & $13,2 \%$ \\
\hline & Identificação direta & $1,8 \%$ & - & - & - & - & - & - & - \\
\hline & Identificação indireta & $4,8 \%$ & - & - & - & - & - & - & - \\
\hline \multirow{3}{*}{ 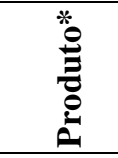 } & Orientação ao mercado & $2,9 \%$ & - & $0,5 \%$ & $0,6 \%$ & $3,7 \%$ & - & $0,4 \%$ & $0,2 \%$ \\
\hline & Orientação ao produto & $5,1 \%$ & - & $1,1 \%$ & $0,7 \%$ & $3,7 \%$ & - & - & $0,4 \%$ \\
\hline & Orientação mista & $0,5 \%$ & - & $0,6 \%$ & - & - & - & - & - \\
\hline \multirow{5}{*}{ 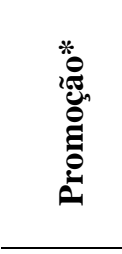 } & Anúncios pagos & - & - & - & - & - & $3,4 \%$ & $0,4 \%$ & - \\
\hline & Agências & - & - & - & - & - & $0,3 \%$ & - & - \\
\hline & Formatos & - & - & - & - & - & $0,1 \%$ & - & - \\
\hline & Planejamento & - & - & $0,3 \%$ & - & - & $1,5 \%$ & $0,9 \%$ & - \\
\hline & Relações públicas/Mídia não paga & - & - & - & - & - & $3,8 \%$ & - & - \\
\hline 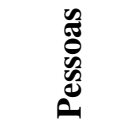 & Papéis e funções & $2,0 \%$ & $1,0 \%$ & $1,1 \%$ & $2,3 \%$ & - & - & - & $2,3 \%$ \\
\hline \multirow{3}{*}{ 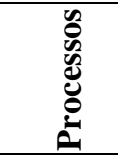 } & Encomenda & $0,9 \%$ & - & - & - & $0,3 \%$ & - & - & $0,7 \%$ \\
\hline & Publisher & $0,7 \%$ & $0,2 \%$ & $0,5 \%$ & $1,1 \%$ & $0,3 \%$ & $2,0 \%$ & $1,1 \%$ & - \\
\hline & Self-Publishing & - & - & - & - & - & - & - & - \\
\hline \multirow{3}{*}{ 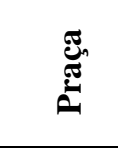 } & Localização geográfica & - & - & $1,1 \%$ & - & - & $0,1 \%$ & $0,5 \%$ & $0,7 \%$ \\
\hline & Lojas Online & - & - & - & - & - & $0,3 \%$ & $1,1 \%$ & $0,6 \%$ \\
\hline & Plataformas & $0,7 \%$ & $1,0 \%$ & $0,1 \%$ & $0,2 \%$ & - & $0,4 \%$ & - & - \\
\hline \multirow{3}{*}{ 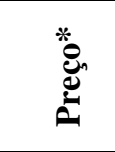 } & Contratação B2B & - & - & $0,1 \%$ & - & - & - & - & - \\
\hline & Estratégia de monetização & - & - & $1,5 \%$ & - & - & - & - & $0,7 \%$ \\
\hline & Formas de Monetização & - & - & $3,5 \%$ & - & - & $0,2 \%$ & - & $0,5 \%$ \\
\hline \multirow{3}{*}{ 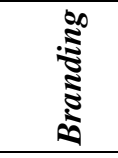 } & Posicionamento artístico & $2,1 \%$ & - & $0,5 \%$ & - & - & $0,5 \%$ & $0,5 \%$ & - \\
\hline & Posicionamento mercadológico & - & - & - & - & - & - & - & - \\
\hline & Posicionamento social & - & - & - & - & - & - & - & - \\
\hline \multirow{3}{*}{ 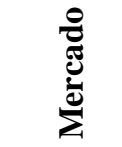 } & Outras empresas & - & - & - & - & - & - & - & - \\
\hline & Outros jogos & $1,1 \%$ & - & - & - & - & - & - & - \\
\hline & Tendências & $1,2 \%$ & $0,6 \%$ & - & - & - & - & - & - \\
\hline
\end{tabular}

* Temas prioritários para aprofundamento das análises

** Não contempla as entrevistas outliers 3, 8 e 12 .

- Valores nulos

Fonte: Elaborada pelo autor, com base nos dados da pesquisa e com o uso da ferramenta NVivo. 
Dos 72 cruzamentos possíveis, somente 6 (seis) comportam mais da metade de todo o conteúdo produzido $(54,1 \%)$. São eles:

i) a gestão do Player, na fase de Conceito;

ii) a gestão do Player, na fase de Manutenção;

iii) a gestão de Produto, na fase de Conceito;

iv) a gestão de Produto, na fase de Acompanhamento;

v) a gestão das ações de Promoção, no Lançamento;

vi) e a gestão de Preço, no Planejamento.

Além disso, foram avaliadas, de forma geral, as gestões de Mercado, de Marca (ou Branding), de Processos, de Praça e de Pessoas que, de certa forma, abrangem a outra metade do conteúdo, além de ter sido feita a comparação com as empresas outliers. Dessa forma, foram feitos dois outros cruzamentos adicionais, a saber:

vii) gestão dos demais aspectos (que engloba os aspectos mencionados acima); e

viii) comparação com as empresas outliers.

Para aprofundar a análise, levou-se em consideração também a distribuição do conteúdo entre os subtemas, que fornecem mais especificidades a respeito dos aspectos de gestão priorizados (Tabela 4).

A seguir esses cruzamentos mais importantes supramencionados são avaliados em profundidade.

i) Gestão do Player, na fase de Conceito

A identificação do público-alvo, na fase de Conceito (que é o momento em que começam a surgir as primeiras ideias e os protótipos do produto), pode ser considerada uma das prioridades da gestão de marketing em vários segmentos de negócios, inclusive no da Indústria de Jogos digitais.

O que se observou entre os entrevistados foi uma espécie de "identificação indireta" ou "tardia" a respeito do conhecimento sobre o público, que ocorreu na maioria das vezes durante ou depois dos primeiros protótipos jogáveis. Anteriormente, eram raras as preocupações com situações como: "Quais são os públicos que não estão sendo atualmente atendidos pelo mercado?" O Entrevistado 7 resumiu essa lógica predominante dos entrevistados da seguinte forma: 
A parte de marketing, definição de público, é um dos maiores gargalos da [Empresa 7], porque a gente ainda tem uma pegada de 'quero fazer um jogo, porque eu gosto do jogo e quero que ele seja bacana'. Então, ainda vamos muito para os tipos de jogos que a gente gosta e a pegada para quem quer, que entra muito no momento. Então, isso a gente ainda está apanhando para fazer certo. Você precisa saber pra quem você está fazendo para tomar as decisões certas de design no projeto. Nos nossos projetos iniciais, o problema era justamente esse: a gente não sabia para quem estava fazendo e acabava criando um monstrinho que não fazia sentido para ninguém.

O termo "identificação indireta do público" foi utilizado para situações deste tipo, pois descreve algumas alternativas às quais esses empreendedores recorrem para suprirem esse ponto cego de gestão. Geralmente, há um movimento de atenção ao mercado (“quais são os jogos que estão fazendo sucesso atualmente?"), visando a entender: gênero, mecânicas e especificidades para, enfim, chegar ao público-alvo (“quem são as pessoas que estão jogando esse jogo?"). O Entrevistado 10 descreveu esse processo:

Então, eu vejo que na última semana tá tendo muito joguinho de descascar fruta. Então, tem joguinho de descascar fruta, joguinho de descascar madeira e esculpir, umas coisas assim. Então, eu vejo o que é tendência. Isso aqui está em alta, então vamos pensar em uma ideia que tenha algo parecido com isso daqui, e tento criar uma ideia partindo de uma origem dessa.

Esse foi um procedimento pouco sistematizado e intuitivo de busca por tendências, dificilmente contando com instrumentos mais robustos como pesquisas de mercado ou buscas em bancos de dados de empresas especializadas.

Mesmo em sua forma mais robusta (sistematizada e criteriosa), esse foi um método criticado por desenvolvedores como o Entrevistado 11, que enxergou o conflito entre a natureza da oferta (um produto criativo) e seu tempo de desenvolvimento (geralmente longo) com a perspectiva de captura de tendências. Segundo ele,

\footnotetext{
No nosso caso, porque isso também é muito subjetivo e cada um faz de um jeito, eu gosto de me afastar disso, no primeiro momento. Me afastar ao máximo de fazer uma pesquisa de mercado. Não sei se é errado, mas acho meio ruim você chegar e falar assim: 'nossa, tem um monte de jogo de terror saindo, então existe uma trend, e eu vou embarcar nessa trend agora'. Porque você vai levar 2 anos para fazer, quando você terminar já saiu da trend. Quando você percebe uma trend já está tarde demais para você seguir (Entrevistado 11).
}

Os exemplos de sucesso da indústria não apontaram uma única fórmula para resolução desse problema. O game Pac-Man, por exemplo, criado por Toru Iwatani no final da década de 1970, teve como base uma pesquisa social e de marketing que procurava entender os hábitos de mulheres japonesas. Chegou-se à conclusão que as mulheres tinham um costume mais frequente do que os homens de comer sobremesas (doces) logo após o almoço, o que fez com que Iwatani 
considerasse fazer um jogo com a temática "comida", a fim de atrair o público feminino para um universo majoritariamente masculino. Então, certo dia, Iwatani estava reunido com sua equipe de desenvolvimento do conceito e pediram uma pizza. Quando a pizza chegou, removeram o primeiro pedaço e veio a inspiração (GABOX, 2018). O resultado está demonstrado na Figura 25 a seguir, que apresenta à esquerda, uma ilustração do personagem jogável de Pac-Man e à direita seu criador comendo sua "fonte de inspiração", visto que o formato do Pac-Man é muito similar ao de uma Pizza sem um dos pedaços.

Figura 25 - Inspiração para criação do videogame Pac Man

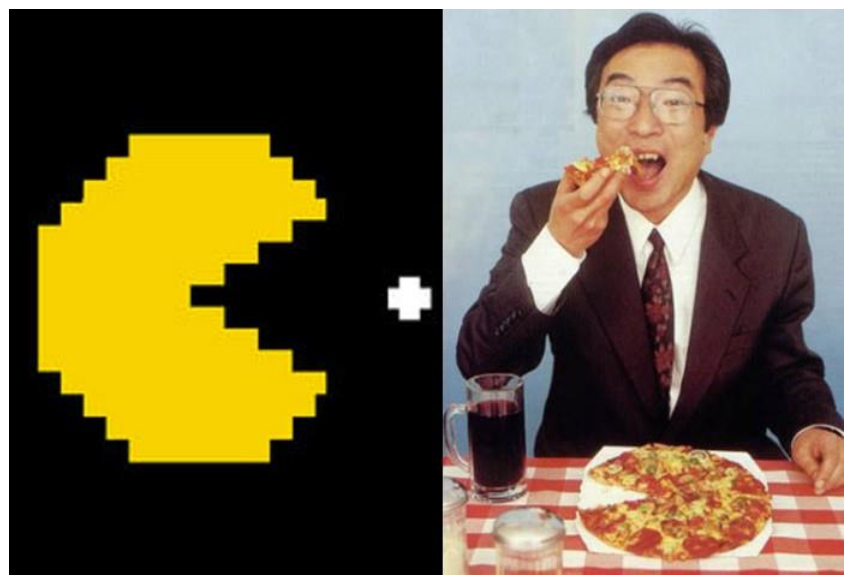

Fonte: Gabox (2018, n.p.).

Um exemplo totalmente oposto é o jogo Counter Strike, criado em 1999, considerado, até hoje, um dos jogos competitivos mais populares do mundo, com 24 milhões de players ativos, segundo dados de fevereiro de 2020 (CLEMENT, 2021). O jogo foi um desejo de seus desenvolvedores de um conceito mais realista para outro jogo, o Half-Life. Assim, o Counter Strike nasceu como extensão do Half-Life, mas seu sucesso foi tão grande que ele acabou se tornando um jogo independente. Não houve, ao menos com base no que se tem registrado historicamente, um trabalho sistematizado de identificação de público, mas um despertar criativo de seus criadores que lhes rendeu frutos colhidos até os dias atuais.

Conclui-se, a partir disso, que se deve reconhecer a complexidade das decisões a serem tomadas e que não há fórmula ou momento específico para entendimento do público potencial na fase de conceito. O que se pode inferir é que o máximo possível de informações acerca dos contextos histórico, econômico, social, mercadológico (a partir de pesquisas de marketing formais ou informais) e até político à disposição dos desenvolvedores podem contribuir (dificilmente farão mal) para a potencialização da criatividade no desenvolvimento de tais projetos. 
ii) Gestão do Player, na fase de Manutenção

Por ter sido o aspecto de gestão mais abordado pelos entrevistados (14,8\% do conteúdo total), manter a base de jogadores (players) depois do lançamento foi considerado crucial para a sustentabilidade da empresa, principalmente, se a manutenção garantir o Engajamento (subtema com 13,2\% de cobertura do texto total) dos usuários em longo prazo, refletindo positivamente no retorno financeiro para a empresa. Segundo o Entrevistado 4,

\begin{abstract}
Tem a base de usuários: se ele [o usuário] consumir $1 \%$ mais já dá um valor muito grande. Se ele fica um pouquinho mais tempo, dá um valor muito grande. Então, às vezes, mudar um botão, dar uma reinterpretação numa tela, mudar a hora que você dá aquele prêmio, tudo isso ajuda muito, mas isso para empresas grandes. A gente ainda não tem muito esse controle. No máximo, o que a gente consegue é colocar alguns marcadores do que o cara está fazendo.
\end{abstract}

Geralmente, os entrevistados costumam fazer referência à rotina de Customer Relationship Management (CRM), sem o saber. Existe uma ciência da importância e do potencial retorno que esse tipo de gestão traria, mas os impedimentos mais comuns à intensificação dessas atividades seriam a falta de conhecimento e de dinheiro para garantir a contratação de pessoas dedicadas, como o gestor de comunidades ou os analistas de dados citados anteriormente. Por isso, é um tipo de atividade entendida como um privilégio de empresas maiores.

O Entrevistado 6 foi o que mais demonstrou contato com essa fase de gestão. Ele alegou, assim como os demais, que "ainda há [havia] muito o que aprender", mas relatou o retorno prático de uma de suas ações. A partir do sistema de Game Analytics de um de seus projetos, ele descobriu que parte dos computadores dos jogadores era de modelos mais antigos que demoravam mais para carregar o conteúdo do jogo toda vez que o mesmo era executado, o que acabava gerando muita desistência em uma fase específica do jogo. Então, eles trabalharam em uma atualização que armazenava essas informações na máquina do usuário uma única vez, aumentando consideravelmente o tempo de carregamento e, consequentemente, os índices de engajamento.

No entanto, esse foi o único caso prático relatado em relação a esse aspecto. No geral, o discurso dos entrevistados foi mais idealista ou superficial, demonstrando uma grande distância entre os planos e a prática, gerada por flagrantes faltas de recursos humanos, financeiros e técnicos. 
iii) Gestão de Produto, na fase de Conceito

Há, basicamente, dois tipos de produtos que demandam dois tipos diferentes de gestão: os jogos próprios e os jogos para terceiros (Governos, marcas ou investidores). Em relação aos jogos para terceiros, os entrevistados manifestaram que há pouco controle sobre suas especificidades, pois a empresa ou a pessoa que realiza a encomenda, geralmente, já traz um conceito de como o jogo deve ser produzido e/ou quais públicos deve atingir. Evidentemente, o processo de desenvolvimento não é unilateral e conta com a interferência da desenvolvedora em diversos momentos, mas o nível de controle é limitado.

Os produtos autorais, por sua vez, fazem parte do domínio dos desenvolvedores e, mesmo havendo a possibilidade de cocriação junto com parceiros (como as Produtoras), é possível enxergar com mais clareza a forma de pensar e de agir das empresas entrevistadas em relação a esse aspecto.

Relembrando o que foi abordado anteriormente, há um espectro de visão estratégica a respeito do produto: ele pode ser compreendido entre os extremos "obra" e "mercadoria". Além disso, também se sabe da relação entre as pesquisas de mercado e as fontes de inspiração de tais produtos, que tendem a fazer um movimento mais de "dentro para fora" do que "de fora para dentro".

Levando isso em consideração, observou-se que há potenciais conflitos entre as empresas mais "idealistas" (que tendem mais ao extremo "obra" e têm uma orientação mais de "dentro para fora") e as expectativas em relação ao mercado. Algumas assumiram o risco de ganhos menores em nome da "arte", mas, em geral, foi possível notar expectativas financeiras mais ambiciosas. O que mais surpreendeu foi a existência por parte da maioria das empresas de algum nível de sistematização da produção (geralmente com o suporte de metodologias ágeis). Segundo o Entrevistado 6,

\footnotetext{
E aí é feito um planejamento normal, como qualquer empresa, com linha do tempo, onde você só destrincha tarefas em equipes; então uma ideia aprovada pela equipe, ela vai para a ideia de conceito. Por exemplo, se for personagem novo, primeiro desenhamos os arquétipos do personagem, como ele seria dentro do jogo, faz todo um processo de cores, sobra, depois disso a gente parte para modelagem, animação, efeitos, som, e depois de todo esse processo estar montado, aí entra a equipe de tecnologia para implementar esse asset.
}

Esses conceitos tendem a passar para uma fase de provação mercadológica, na fase de Acompanhamento, descrita a seguir. 
iv) Gestão de Produto, na fase de Acompanhamento

A fase de Acompanhamento geralmente corre em paralelo com o desenvolvimento do jogo e contempla a avaliação do produto em relação ao potencial de mercado. Essa avaliação bifurcou-se em dois ramos: o técnico, que se referiu ao bom funcionamento do jogo; e o mercadológico, que se referiu à recepção dos potenciais jogadores.

O ramo técnico foi resumido pelo Entrevistado 2 da seguinte maneira:

Isso é muito cansativo. O [sócio do entrevistado] fez isso sozinho por muito tempo. Eu ajudei bem pouco, porque era questão de ter que testar as fases, balanceamento, a progressão dos personagens dentro do jogo, depois que a gente inseria o modo competitivo, o balanceamento de arma, de nível. É muito cansativo. Joga-se muito o jogo, testa-se em várias plataformas. Se o jogo suporta entrada de vários controles, precisa testar o controle.

Esse processo descrito pelo Entrevistado 2 envolveu, em geral, a participação dos chamados Game Testers, pessoas da organização (ou contratadas) com a função de estressar os mecanismos do jogo em busca de bugs ("falhas"). Seria análogo, no mercado alimentício, ao sentido de garantir a boa conservação e a possibilidade de consumo humano de um alimento. Ou seja, é o "mínimo" (muito trabalhoso) que em boa medida está fora do escopo de marketing.

O ramo de avaliação mercadológica (que pertence ao escopo de marketing) também foi muito valorizado e executado pelos representantes das empresas entrevistadas - sendo uma surpresa positiva no decorrer da análise. Poderia se acreditar que, por serem micro e pequenas empresas, não existiria a prática de testagem com potenciais jogadores, no entanto, o que se pôde discutir foi o nível de maturidade dessa prática, mas não a percepção da importância e da incorporação no dia a dia dos entrevistados. Segundo o Entrevistado 4,

Nós penamos para ter um jogo para testar. Aí levamos lá na [Instituição pública de
ensino X], para a criançada e a primeira pergunta que me lembro até hoje foi: “tio o
que é esse coração preto de cabeça para baixo?". O 'moleque' não sabia o que era um
naipe de espadas. Ninguém [do time de desenvolvimento] falava 'eu me garanto'
mais. Foi aí que a gente tomou o primeiro 'baque', a gente achou que fosse falar com
a molecada como falava com a gente [adultos]. Então tá, joga na prancheta de novo,
vamos replanejar, 'pa pa pa pa pa pa', pegamos os feedbacks, visitamos várias
[Instituições públicas de ensino X] né? Pegamos feedbacks, planejamos melhorias no
jogo, lançamos o jogo e todos gostaram.

Com exceção de poucos casos como esse, esses testes geralmente foram feitos com pessoas da própria empresa ou próximas a elas (amigos e familiares). Os entrevistados também aproveitaram oportunidades como eventos da área para expor o produto e coletar feedbacks do público ou via redes sociais e outros canais online. Alguns testes foram estruturados de alguma 
forma (roteiros com pontos chave de avaliação), mas, no geral, foram realizados de maneira informal e apresentaram o desafio de "separar o joio do trigo" (ou seja, separar os feedbacks produtivos dos improdutivos).

v) Gestão de Promoção, na fase de Lançamento

Devido às limitações financeiras das empresas analisadas, as formas mais aderidas de promoção envolveram ações que demandaram mais investimento de tempo do que de dinheiro, resumidas pelo Entrevistado 11 da seguinte forma:

[...] marketing de graça, que é o marketing custo zero, principalmente em rede social, ainda fazemos um pouco. É site, blog, postar em fórum, postar sobre desenvolvimento, mostrar a tela do programa em desenvolvimento, porque ajuda, né? Quando você não tem muito tempo pra focar no marketing [pago].

Além da descrição dos meios utilizados (blogs, fóruns e redes sociais), o trecho acima reafirma o conhecimento predominante dos entrevistados: o marketing foi tratado como sinônimo de promoção ou publicidade. Não se usam os termos "publicidade orgânica" ou, mais acuradamente, relações públicas, para se referirem a esse tipo de ação, mas "marketing de graça" ou "marketing custo zero".

Ações desse tipo também contemplaram a disponibilização do jogo a influenciadores digitais (youtubers gamers, por exemplo), que testaram e relataram suas impressões entre seus seguidores ou mídias especializadas da categoria, cujos jornalistas escreveram artigos com os mais variados enfoques (revisões, avaliações, informações sobre o lançamento, "vazamentos" etc.).

No que diz respeito a "marketing pago" (utilizando-se a lógica dos entrevistados), alguns relataram experiências com plataformas como Google Ads e Facebook Ads, mas, mesmo sendo ferramentas com retornos promissores, não há como sustentar sua manutenção por questões de custo.

A gente não está querendo ir para esse caminho, porque a gente não vai ter como 'brincar disso' [anúncios pagos online]. Não vai ter como manter uma campanha assim, sustentável. O que a gente tem, na verdade, porque o edital tinha sim uma parte reservada para marketing, uma parte muito pequena, e aí a gente reservou isso para contratar uma pessoa que sabia o que estava fazendo para tocar essa campanha. Porque, como eu falei, minha formação é em programação, a gente tem um artista, tem um músico, nenhum de nós tem uma experiência com marketing, nenhum de nós domina, então a gente traçou esse plano, com o que a gente sabe, com o melhor que a gente sabe, mas é bom a gente ter alguém de marketing no time, até mesmo para validar, para falar 'o plano vai ser esse mesmo' e agora vamos executar e executar isso da melhor forma possível (Entrevistado 9). 
A expressão utilizada pelo Entrevistado 9, "não brincar disso" significa que não há condições financeiras para levar a cabo ações de publicidade. O desconhecimento acerca do funcionamento e da operação também foi uma barreira, pois não houve pessoas capacitadas no time para tal tarefa. Esse quadro se reverteria, sob o ponto de vista dos entrevistados, a partir da atuação junto às publishers, que contariam com experiências e recursos financeiros, técnicos e humanos para tal. Tanto que os jogos hiper casuais (que dependem majoritariamente de publicidade online) são geralmente disponibilizados ao mercado com o auxílio de publishers que dividem ou assumem completamente os riscos financeiros do lançamento.

O que mais chamou a atenção em toda essa dinâmica de publicidade das empresas foi a predominância de canais online, constituindo-se na maioria de meios de publicidade dos jogos no momento dos lançamentos. Isso ocorreu porque os meios online de publicidade e de relações públicas apresentaram atrativos como: baixo custo, facilidade de uso, facilidade de disponibilização da informação, possibilidade de acompanhamento instantâneo de resultados, entre outros. Pode-se afirmar que esse foi o aspecto mais predominante de marketing digital das empresas analisadas.

vi) Gestão de Preço, na fase de Planejamento

A monetização (termo equivalente à precificação, nesse setor) pode variar consideravelmente dependendo da plataforma, dos objetivos e da complexidade dos jogos. Os jogos são divididos em 2 (duas) grandes tipologias: jogos premium - jogos pagos cuja compra ocorre uma única vez; e jogos free to play - que não precisam de pagamento para realização do download ou de compra de mídia física, mas que podem conter anúncios ou itens para compra dentro do jogo (moedas virtuais). Também são possíveis situações em que os jogos premium apresentam possibilidades de monetização, mais comuns em free to play.

Os jogos do tipo premium são menos considerados em projetos mais simples e com maior foco em dispositivos mobile. Os jogos mais populares para esses casos são os free to play, que disputam os espaços com milhares de outros jogos em lojas virtuais como a Google Play e Apple Store.

Em jogos free to play há o desejo, por parte dos entrevistados, de que a monetização via anúncio seja gradativamente substituída pela monetização via moedas virtuais. Isso porque a monetização via anúncio consiste em mostrar dentro do jogo uma peça publicitária de qualquer marca interessada, com potencial de quebrar o fluxo de experiência do usuário, gerando raiva 
ou frustração. Mesmo assim, a experiência com anúncios não pode ser completamente eliminada, pois é importante por ser, muitas vezes, a única fonte possível de receita.

A monetização via compra de itens dentro do próprio jogo (moedas virtuais), por sua vez, é vista com um misto de admiração e receio, pois não é fácil criar um sistema econômico dentro do jogo. Seria necessário um entendimento sobre questões de economia como elasticidade de demanda em função do preço, inflação, deflação e outros conhecimentos que equilibrariam uma experiência agradável para o usuário, com uma lucratividade sustentável para a empresa. Segundo o Entrevistado 7,

Isso é uma coisa que a gente está apanhando agora [monetização], porque a gente apresentou isso para uma publicadora. Um jogo mobile, no caso, tem que ter os custos lá dentro. Primeiro, que não temos dados de mercado para saber isso. A gente não tem experiência muito grande com mercado de mobile, então usamos a métrica de tempo, por exemplo. O cara gasta 1 hora para conseguir 100 moedinhas no jogo, então o quanto que vale essa hora de jogo dele.

A gestão do preço (ou gestão da monetização), portanto, não foi sistematizada ou planejada de forma robusta, criando um potencial desencontro entre as possibilidades de ganho e os ganhos reais, mesmo que o produto (jogo) tivesse um bom nível de qualidade.

vii) Gestão dos demais aspectos

- $\quad$ Gestão de pessoas

Um aspecto de marketing que permeia todo o processo produtivo (do conceito à manutenção) é a gestão de pessoas, boa parte delas concentrada na produção e na administração burocrática e praticamente nenhuma delas concentradas na gestão e implementação de atividades de marketing. As "pessoas" que os entrevistados sentem maior falta em seu quadro de colaboradores, que teriam atribuições de marketing (mesmo sem terem ciência disso), são os gestores de comunidade e os analistas de dados (cientistas de dados, estatísticos e correlatos).

- $\quad$ Gestão de processos

Os processos de marketing, conforme discutido anteriormente, são entendidos como processos de promoção: planejar uma campanha, colocá-la no ar e acompanhá-la. Quando o desenvolvedor atribui esse tipo de tarefa a uma publicadora, ele acaba terceirizando muito mais tarefas de marketing a tal empresa sem o perceber. Os relatos dos entrevistados demonstraram que as publishers os ajudavam a: distribuir as cópias online ou off-line; determinar os preços e as formas de monetização; selecionar e gerir canais de distribuição; definir estratégias de 
internacionalização da oferta; além de "fazer o marketing" (termo utilizado como sinônimo de promoção ou divulgação), entre outras atividades.

\section{- $\quad$ Gestão de praça}

Em termos de gestão de praça das empresas, nota-se certa concentração em meios de distribuição online (lojas online como Steam, PlayStore e Apple Store) que fazem com que o jogo não se restrinja ao território nacional, pois é possível, com alguns poucos comandos, selecionar e filtrar os países de interesse. O Entrevistado 4 afirmou: “O jogo já nasce global”.

A maior dificuldade dessa internacionalização "instantânea" está na burocracia envolvida na conversão de moedas e especificações dos sistemas de taxas de cada país, que exigem equipes financeiras e jurídicas, o que não é a realidade observada. No que diz respeito a ações de marketing (e que foi pouco abordado pelos entrevistados), seria um entendimento mais profundo das diferentes culturas e tendências de cada país para conseguir melhorar a atuação internacional da empresa.

\section{- Gestão de marca (ou branding)}

A gestão de marca (ou branding) foi um assunto pouco abordado, provavelmente por se tratar de retornos em médio e longo prazos. Como a atuação do dia a dia é crucial para sua sobrevivência (ou como afirmou o Entrevistado 4: "vender o almoço para comprar a janta"), o maior foco está em atividades de performance e de retorno financeiro em curto prazo. Algumas poucas manifestações de preocupação com a marca dizem respeito a seu posicionamento: algumas empresas priorizam a qualidade de seus produtos, outras, o seu aspecto artístico e outras, o seu aspecto social (educativo, ambiental ou humanitário). Concluiu-se que, de fato, não existiam ações sistematizadas de gestão de marca.

\section{- $\quad$ Gestão de mercado}

Por fim, o mercado foi visto pelos entrevistados como amplo e um lugar onde há espaço para todos. Não houve nenhuma preocupação explícita ou latente com relação à concorrência, pois se acreditava que existiam muitos gêneros de jogos e tipos de jogadores que ainda não haviam sido explorados. As análises de mercado realizadas focaram mais nos tipos de jogos (nos que já existem e nos que ainda não existem), no lugar da concorrência empresarial ou das necessidades do público. O Entrevistado 1, por exemplo, relatou a utilização do método Unique Selling Proposition (USP) (NIU; WANG, 2016) que busca os "furos" de oferta no mercado e 
procura cobri-los com algo inédito, sempre com foco nos jogos que ainda não existem e não necessariamente nas necessidades dos consumidores (uma preocupação decorrente).

\section{viii) Comparação com as empresas outliers}

Por serem empresas de maiores portes ou com maiores níveis de maturidade em relação à gestão de marketing, esperava-se que houvesse diferenças tanto no foco de gestão quanto na forma como essa gestão ocorria. Quantitativamente, a Tabela 5 revela diferenças entre a concentração de texto em alguns temas em detrimento de outros, ao se comparar as entrevistas outliers com as regulares. Essa tabela demonstra os coeficientes multiplicadores que indicam a maior ou a menor incidência de texto em aspectos específicos de gestão. Por exemplo: a gestão de produto, na fase de avaliação, apresenta o coeficiente de 20,8, o que significa que esse foi um aspecto abordado em torno de 21 vezes mais entre os outliers do que entre os entrevistados regulares. Outro extremo seria a gestão de promoção, na fase de lançamento, que foi menos abordada pelos outliers em relação aos entrevistados regulares (coeficiente de 0,2 ou $20 \%$ do conteúdo das entrevistas regulares). O equilíbrio está em torno do coeficiente 1 (volumes similares de conteúdo). Os coeficientes 0 indicam que o aspecto não foi abordado entre os outliers, mas foi mencionado entre os entrevistados regulares.

Cabe maior atenção, dada a sua grandeza, à quantidade de vezes que os outliers abordaram a questão da gestão de produto, na fase de avaliação (Coeficiente de 20,8). Ao avaliar mais profundamente o conteúdo, entendeu-se o que está por trás disso: as empresas outliers demonstraram forte orientação para a performance e maior desapego aos produtos que não apresentaram resultados financeiros satisfatórios.

Essa sistematização da avaliação do produto causou um distanciamento sentimental desejável em termos produtivos, fazendo com que recursos escassos e preciosos fossem alocados em projetos com maior potencial de retorno. É um típico traço observado nas empresas maiores, outliers 3 e 12. No entanto, a empresa outlier 8, mesmo sendo de pequeno porte, demonstrou esse tipo de mentalidade. Segundo o Entrevistado 8,

Eu tenho uma tabela que faço esses cálculos. Então, eu já sabia que esse jogo que lancei precisava vender 300 e poucas cópias, e aí ele já entrou dentro dessa métrica. Então, desses dois jogos que eu queria que vendessem mais de 300, um deles já vendeu e eu já recuperei o dinheiro. E esses números vão aumentando a partir da média de crescimento que eu tenho. Como eu tabelo tudo o que vendo, eu sei que meu primeiro jogo vendeu " $x$ ", o outro "x $+20 \%$ ", o outro $20 \%$ em relação ao anterior. Então, eu vou fazendo esses cálculos e tentando manter essas médias. E é como eu vejo hoje. Como foi o meu crescimento a cada 2 meses. 


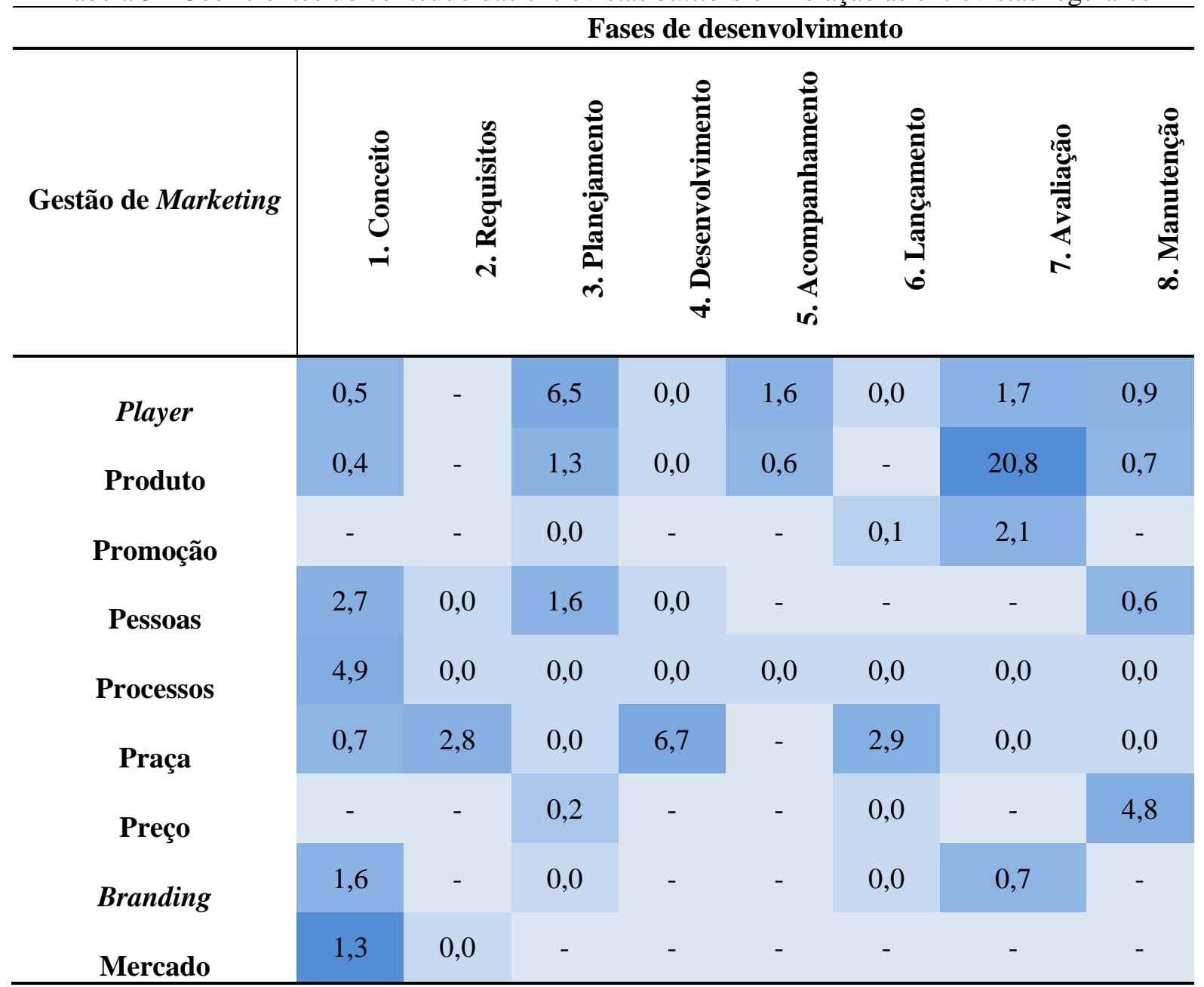

\section{- Valores nulos}

Fonte: Elaborada pelo autor, com base nos dados da pesquisa e com o uso da ferramenta NVivo.

Outros aspectos que reforçam essa gestão mais profissional de marketing entre as empresas outliers são as preocupações com a gestão do player, na fase de planejamento (coeficiente de 6,5), e também com a dinâmica inicial do projeto, na gestão dos processos, na fase de conceito (coeficiente de 4,9). O Entrevistado 3 relatou um criterioso processo de seleção de ideias que se tornou protótipo e mereceu maiores investimentos.

Na gestão da praça, na fase de desenvolvimento (coeficiente de 6,7) e na gestão do preço, na fase de manutenção, o Entrevistado 12 relatou a atuação de diversos profissionais, incluindo economistas, para criarem um ambiente econômico virtual que fizesse sentido para os jogadores - de diversas nacionalidades (um sentimento de justiça pelos preços pagos face aos benefícios) - e para a empresa (maiores lucros). 


\subsubsection{Inteligência de Marketing}

Ao mesmo tempo em que pode ser tratado como um tema de gestão de marketing, a inteligência de marketing, que possui um ferramental extremamente útil para a tomada de decisão dos gestores, exige sua separação por se tratar de uma temática transversal, abrangente e com uma série de possibilidades em termos de abordagens e análises.

Levando-se isso em conta, criou-se mais uma categoria de codificação que abrangeu códigos-tema em inteligência de marketing, segmentando todo o conteúdo pertinente e resultando na distribuição percentual do conteúdo entre as fases de produção discriminadas na Tabela 6 a seguir.

Tabela 6 - Temas mais abordados em inteligência de marketing ao longo das fases de desenvolvimento**

\begin{tabular}{|c|c|c|c|c|c|c|c|c|}
\hline \multirow[b]{2}{*}{ Inteligência de Marketing } & \multicolumn{8}{|c|}{ Fases de desenvolvimento } \\
\hline & نْ & 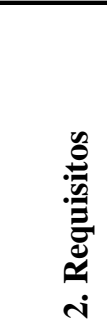 & 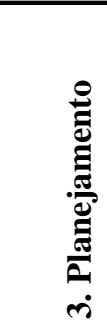 & 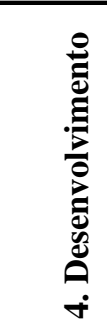 & 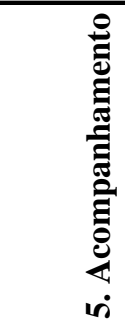 & 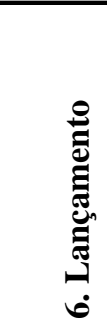 & 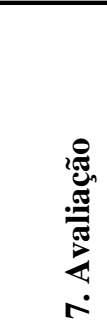 & \\
\hline Análise de gêneros & $11,6 \%$ & - & - & - & $1,5 \%$ & $0,6 \%$ & $1,1 \%$ & $2,3 \%$ \\
\hline Game analytics & - & - & $4,3 \%$ & $0,2 \%$ & - & - & $0,3 \%$ & $11,3 \%$ \\
\hline Testes para lançamento & $1,4 \%$ & - & - & - & $13,7 \%$ & $0,6 \%$ & - & - \\
\hline CRM & - & - & - & - & - & $2,1 \%$ & - & $11,0 \%$ \\
\hline Mensuração do sucesso & - & - & $3,0 \%$ & - & $0,2 \%$ & $0,4 \%$ & $7,2 \%$ & - \\
\hline Análise de mercado & $6,1 \%$ & - & $1,0 \%$ & - & $1,1 \%$ & - & $1,0 \%$ & $1,3 \%$ \\
\hline Análise de conversão & $0,8 \%$ & $0,7 \%$ & - & - & - & $1,0 \%$ & $4,6 \%$ & $1,2 \%$ \\
\hline Gestão e processos & - & $0,9 \%$ & - & - & - & - & - & $4,0 \%$ \\
\hline Resultados de comunicação & - & - & - & - & - & $3,0 \%$ & $0,2 \%$ & - \\
\hline Análise de canais (plataformas) & - & $0,2 \%$ & - & - & - & - & - & - \\
\hline Testes de comunicação/criativos* & - & - & - & - & - & - & - & - \\
\hline
\end{tabular}

*Esse tema foi tratado somente pelo entrevistado outlier 12.

**Não contempla as entrevistas outliers 3,8 e 12 .

- Valores nulos

Fonte: Elaborada pelo autor, com base nos dados da pesquisa e com o uso da ferramenta NVivo.

De forma geral, a gestão e os processos de inteligência de marketing não são rotinas estruturadas (reflexo na cobertura de conteúdo do código gestão e processos de somente 4,9\%), ao contrário do que foi observado nas empresas outliers. Mesmo assim, algumas iniciativas de tratamento e análise de dados foram valorizadas e descritas pelos entrevistados. 
A análise de gêneros foi a classificação utilizada pelo autor para um tipo de análise mencionada com maior frequência (somando-se o volume de todas as etapas, resultou $17,1 \%$ de cobertura). Basicamente, consiste em avaliar os gêneros dos jogos que estão no mercado e as tendências para encontrar aquilo que os jogadores mais estão jogando no momento ou o inverso, aquilo que os jogadores ainda não estão jogando.

Algumas empresas utilizam sites especializados como fontes de informação, os quais informam a respeito dos valores de faturamento e das vendas desses jogos, mas, em geral, são análises não estruturadas de teor qualitativo. A maior concentração desse tipo de análise está na fase de conceito, quando as ideias dos jogos ainda estão surgindo e há maior abertura para alterações no produto.

O game analytics consiste em entender o comportamento do usuário durante o jogo, geralmente contando com o auxílio de programas próprios ou de terceiros para "gravar" o que está acontecendo. Com isso, é possível entender eventuais problemas de progresso que levam à desistência de jogadores. É algo muito valorizado, mas pouco aplicado na prática por conta dos recursos disponíveis. Trata-se de uma "subárea" de CRM, que também é tratada de forma mais intuitiva e orgânica.

Os testes para lançamento são avaliações estruturadas (em forma de grupos de foco ou uso de formulários) ou não estruturadas (chamar amigos e familiares para testar o jogo, por exemplo). Cabe destacar a valorização que os entrevistados deram a esse tipo de teste e em sua fluidez (geralmente seguem processos ágeis de gestão: formulação, prototipação, teste e reformulação). O que muitas vezes ocorre é a incapacidade de transformar esses dados em inteligência para melhoria efetiva do jogo.

As demais formas de análise seguem um padrão geral similar. São realizadas de forma mais intuitiva e menos profissional. A análise de sucesso do jogo, por exemplo, pode contar com indicadores objetivos, como retorno sobre investimento, mas também com indicadores indiretos e de natureza qualitativa, como "visibilidade do jogo", feedbacks da comunidade, entre outros. Estruturas mais robustas de análise de dados contam com a presença de indicadores objetivos e ferramental analítico que suportam a tomada de decisão. 


\subsection{GRANDES DESAFIOS DA GESTÃO DE MARKETING}

Haja vista uma série de pontos de evolução e potencialidades dessas empresas, decidiuse como objetivo principal da presente dissertação elencar, descrever e qualificar grandes desafios que as micro e pequenas empresas desenvolvedoras brasileiras de jogos digitais precisam superar para melhorar sua gestão de marketing, com base na visão do autor, levandose em consideração todas as análises realizadas.

Não houve a pretensão da exaustão ou da criação de fundamentos para toda e qualquer empresa que detivesse as características das empresas estudadas, pois foi uma limitação do próprio escopo de pesquisa: qualitativo e exploratório. Houve certa preocupação com o aumento da produtividade da gestão de marketing dessas empresas a partir da identificação de pontos chave (que não cobriram a totalidade dos problemas), mas que tiveram potencial para habilitar essas organizações a novos patamares de crescimento e, consequentemente, a novos desafios.

A lista a seguir contém 5 (cinco) grandes desafios elencados pelo autor cuja ordem apresentada não necessariamente denota prioridade ou maior/menor grau de importância. Na verdade, o autor percebeu que a superação de tais desafios estaria em linhas de ações paralelas, a depender da capacidade e da realidade de cada empresa no contexto da gestão de marketing. Assim, o autor realizou inferências e sintetizou em forma de desafios os aprendizados acumulados pelas análises precedentes, levando em consideração sua experiência acadêmica e mercadológica.

\subsubsection{Desafio 1: Ir além do "P" de Promoção}

Não há perspectiva de melhoria daquilo que não se conhece. Caso a gestão de marketing não seja entendida em sua extensão e amplitude de atuação, todos os outros esforços feitos "às cegas" tenderão a incorporar taxas de risco muito altas.

Se a promoção for um conjunto de atividades à parte, separada das decisões de canais, preço, produto, processos e pessoas, sendo relegada completamente a terceiros, haverá uma espécie de "vale tudo" publicitário que dificilmente respeitará o posicionamento artístico, social ou técnico da empresa, trazendo para a base públicos de baixo valor e colocando em risco a longevidade do produto e, eventualmente, da própria empresa.

A superação desse desafio na prática apresenta camadas de complexidade como: a formação em outras áreas da maior parte dos fundadores; a alocação limitada de recursos 
financeiros para áreas não integrantes do núcleo de produção dos jogos; a falta de profissionais especializados nas poucas posições de quadro funcional disponíveis; as tecnologias que, por mais que tenham facilitado a gestão e a implementação de ações integradas de marketing nos últimos anos dependem de operadores habilitados e, em boa medida, dedicados exclusivamente a tais funções.

Em termos estratégicos, podem-se considerar ações de diversas naturezas com o propósito de educar e de auxiliar os líderes na consolidação de uma visão abrangente e integrada de marketing em seu dia a dia. Nos aspectos tático e operacional, a disponibilização de recursos gratuitos ou de baixo custo para auxiliar na gestão de marketing, como ferramentas digitais que auxiliem no planejamento e no acompanhamento de ações de marketing, também é uma opção.

O SEBRAE, por exemplo, possui em seu portal online uma série de materiais que abordam a gestão de marketing tanto em nível estratégico quanto em níveis tático e operacional (Figura 26). São materiais de fácil consumo e que não exigem formação prévia na área (SEBRAE, 2021).

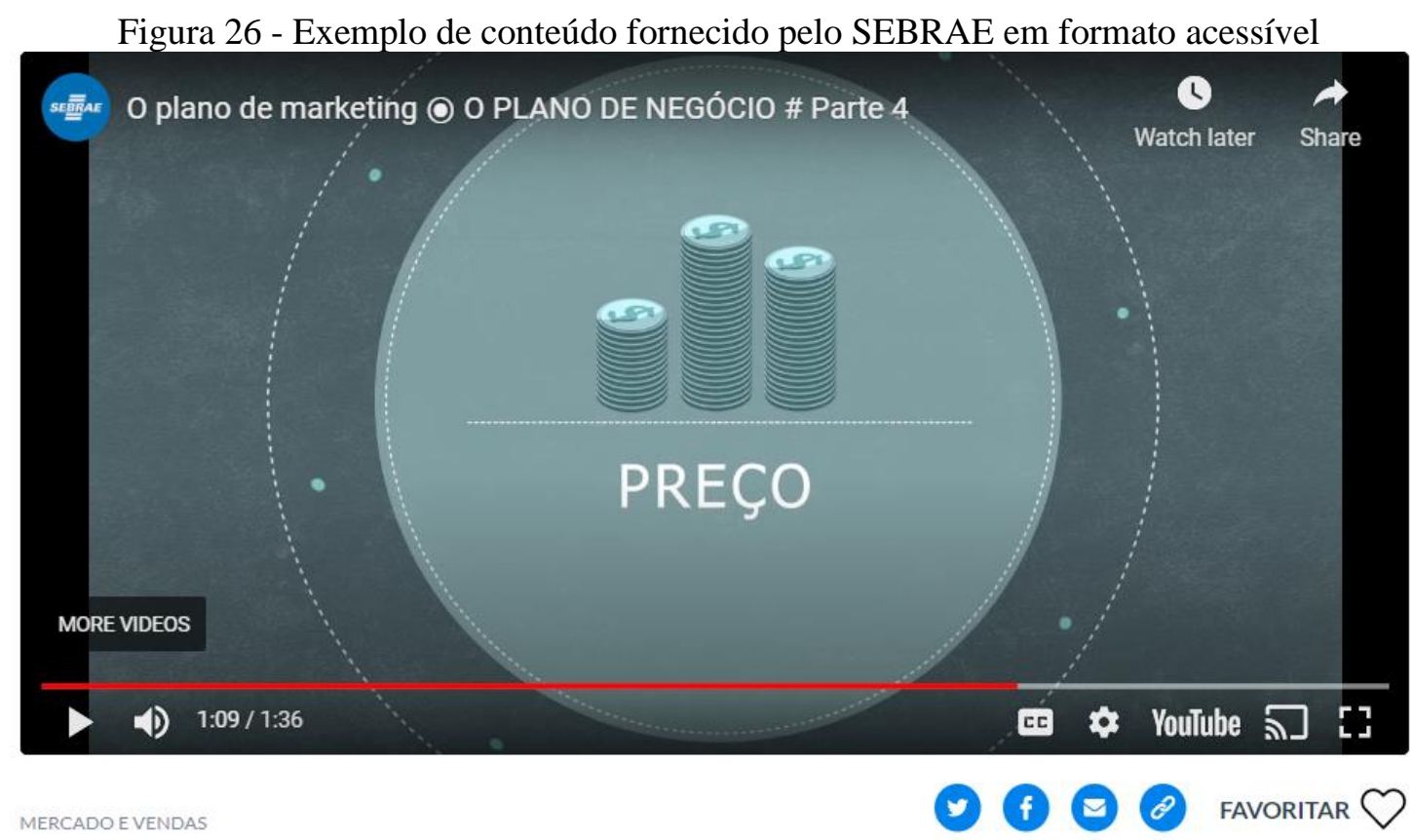

\section{O Plano de Marketing}

O plano de marketing melhora a oferta de produtos e serviços, cria estratégias de preços, promoções e a organiza os canais de venda.

Fonte: SEBRAE (2021, n.p.).

A principal limitação desse tipo de conteúdo é a sua generalização a vários setores, o que pode entrar em conflito com as características diferenciais das Indústrias Criativas, mais especificamente da Indústria de Jogos Digitais. 
De forma mais ampla, Chen, Chang e Lee (2015) argumentam que a profissionalização e o desenvolvimento de pequenas empresas de Indústrias Criativas no mercado chinês dependeu de complexas redes de relacionamento divididas em 4 (quatro) categorias: 1) família - pessoas próximas que apoiam os empreendedores financeira e emocionalmente; 2) comunidade - para obtenção de recursos e conhecimentos iniciais; 3) negócios - para compartilhamento de experiência e expertise na área de atuação; e 4) governo - para investimentos de base e incentivos fiscais.

Trazendo essa lógica para o mercado brasileiro, os entrevistados relataram ainda a necessidade de melhoria do desenvolvimento dos aspectos 3 e 4 (negócios e governo, respectivamente), que poderiam alavancar a profissionalização global da empresa, tendo como consequência natural a profissionalização da gestão de marketing.

\subsubsection{Desafio 2: Engajar e Manter a Base de Jogadores}

Ao contrário do que se poderia supor em uma análise menos profunda, as fases de testagem durante o desenvolvimento não chegaram a se limitar aos aspectos técnicos, pois também envolveram testes com pessoas reais, havendo preocupação com a satisfação dos jogadores. Obviamente, houve uma série de oportunidades de melhoria em relação aos métodos empregados, mas, desde o avanço das tecnologias digitais nos últimos anos, produzir um protótipo jogável para teste não é atualmente uma das maiores preocupações dos desenvolvedores (principalmente em se tratando de jogos simples para dispositivos móveis que podem ser feitos em poucos dias ou em horas).

Com uma mentalidade ágil de testagem, mensuração, descarte ou reaproveitamento, a parte mais crítica da vida de um jogo está em sua fase de manutenção. É nessa fase que os esforços de desenvolvimento, teste e lançamento já foram empregados em considerável escala, tornando necessária a existência de uma operação capaz de engajar e de manter a base conquistada de jogadores.

Para que isso seja possível, é preciso trabalhar uma gestão de relacionamento com o cliente $(\mathrm{CRM})$ capaz de reagir às demandas diretas e indiretas dos jogadores. Por demandas diretas entendem-se os pedidos da comunidade relacionados a mudanças que podem ser benéficas ao jogo; por demandas indiretas entendem-se as análises de comportamento e de fluxo dentro jogo que evidenciem pontos de melhoria capazes de incrementar a experiência e o desejo dos jogadores de continuarem engajados. 
Essa gestão de relacionamento, no entanto, depara-se com as já conhecidas barreiras dessas empresas: dinheiro, mão de obra e conhecimento. A principal esperança de solução para esses problemas é um Gestor de Comunidades (uma possível solução), que una todas essas dificuldades em simultâneo. No entanto, para contratar alguém com esse conhecimento e contar com sua mão de obra, é necessário ter dinheiro em caixa.

Soluções mais viáveis podem estar em tecnologias mais acessíveis e intuitivas que facilitem essa gestão de relacionamento. Ao pesquisar no Google algo como "CRM free", uma série de softwares gratuitos, e de qualidade razoável, surgirá para pronta utilização.

Mesmo assim, o operador dessa tecnologia precisa separar bem a "filosofia de gestão de relacionamento" das ferramentas de CRM, porque a tecnologia não é capaz de tomar decisões sobre dúvidas como: "quais são as informações mais importantes que devo armazenar no banco de dados?"; “quais são os canais de comunicação que devem formar o ecossistema de relacionamento com os jogadores?”; “como os jogadores devem ser tratados a cada interação?”; além de outras. Ademais, é preciso uma mínima dedicação de tempo, o que pode impactar os custos associados à mão de obra.

\subsubsection{Desafio 3: Impactar Mais Eficientemente os Públicos Potenciais}

Apesar de o mercado ser promissor e de apresentar altas taxas de crescimento, a quantidade de jogos lançados diretamente tende a superar o tempo e a disponibilidade da demanda, fazendo com que muitos jogos não entrem no estágio de consideração dos jogadores, pois eles sequer chegam a saber de sua existência.

A partir dessa constatação, é compreensível que a palavra "marketing” entre os desenvolvedores carregue tanto o significado de "promoção" como o de "publicidade", pois se trata de uma das fases mais críticas de determinação do sucesso ou do fracasso de seus jogos.

É compreensível também o grande depósito de confiança nas publishers, pois o risco financeiro de ações promocionais do jogo, em sua fase de lançamento, é muito alto para uma organização que não possui o conhecimento ou os meios para tal.

$\mathrm{O}$ que as desenvolvedoras fazem atualmente pende mais para relações públicas do que para publicidade, em boa medida por conta de questões financeiras. Também se pode inferir, mesmo não tendo sido explicitado na fala dos entrevistados, é que a ignorância a respeito do funcionamento de meios de promoção online é mais um agravante desse afastamento. É possível afirmar isso utilizando como exemplo a Empresa 8, que embora seja de pequeno porte, 
consegue, com poucos recursos promocionais, impactar uma quantidade satisfatória de potenciais jogadores via publicidade paga.

Por outro lado, a Empresa 12 queixa-se da falta de informações de impacto disponibilizadas por provedores de serviços publicitários online, mas isso está longe de ser a realidade das micro e pequenas empresas, pois elas sequer trabalham com aproveitamento mínimo das informações já existentes.

\subsubsection{Desafio 4: Converter Dados em Inteligência de Marketing}

Se houve algo que pareceu não faltar nas empresas entrevistadas foram dados. Um dado é um registro que pode se converter em informação útil ou ficar em um limbo de coisas que nunca terão oportunidade de "ver a luz do dia".

São muitas fontes de dados disponíveis (sites especializados, relatórios de pesquisa, ferramentas de analytics, gerenciadores de lojas online etc.), mas pouca capacidade de processamento e análise, que nada tem a ver com a tecnologia (que é abundante e razoavelmente acessível) e sim com a mão de obra e o conhecimento disponível nessas organizações.

Para analisar dados é necessário conhecimento técnico (programação, manipulação de programas de análise ou de banco de dados) e estatístico/inferencial (processar análises qualitativas ou quantitativas), mas depende principalmente de um profundo conhecimento de marketing que, como vimos, não é a regra entre as empresas analisadas.

Se a liderança não reconhece problemas ou não estabelece objetivos de marketing, como atração, conversão, engajamento, retenção, entre outros, não será possível atacar tais frentes com o uso de dados. As análises poderão ser feitas, mas, sem um propósito, perder-se-ão no conjunto de coisas "legais" e "interessantes" que poderão ser feitas, dando espaço para outras prioridades.

A solução pode vir de tecnologias ou de inciativas empresariais mais acessíveis, que auxiliem na formação de uma estrutura mínima de gerenciamento e de análise de dados voltadas à resolução de problemas de marketing e que ao mesmo tempo não quebrem o fluxo de produção de outras áreas dessas empresas. 


\subsubsection{Desafio 5: Atender aos Anseios do Mercado sem Perder a Essência}

Esse é um desafio que não parece ser exclusivo das micro e pequenas desenvolvedoras brasileiras de jogos digitais, mas de todas as empresas criativas do planeta. Uma das características mais marcantes das Indústrias Criativas é o potencial conflito entre a liberdade de criação e a sistematização dos processos produtivos que objetivam a lucratividade.

Um desses processos produtivos é o de gestão de marketing, que impõe prazos, especificações de público, preços, locais de atuação e outros limites que podem podar a capacidade criativa dessas empresas.

Os entrevistados mais resistentes a abordagens de marketing, em especial a análises de comportamento do consumidor, parecem seguir a máxima de uma frase muito conhecida de Steve Jobs: "People don't know what they want until you show it to them" 68 ("Os consumidores não sabem o que querem até que ofereçamos a eles", tradução nossa) (JOBS ${ }^{69}, 1997$ apud RONDANI, 2013; GOOD READS, 2021). Isso é verdadeiro para o contexto de produtos inovadores, mas o que poucos sabem é que além de não invalidar, reforça muito a necessidade de implementação de uma verdadeira gestão de marketing nas organizações.

O próprio Jobs exaltou e reconheceu a disciplina de marketing como uma das alavancas de sucesso e de desenvolvimento da Apple, pois foi uma das poucas a conseguir ir além da superficialidade promocional das empresas de seu setor com a campanha "Think Different" ("Pense Diferente", tradução nossa) para sua nova linha de computadores Mac.

Em uma apresentação do conceito da campanha a colaboradores da empresa, Jobs iniciou seu discurso com a seguinte frase "For me, marketing is about values" ("Para mim, marketing trata-se de valores", tradução nossa) (JOBS, 1997). E é essa frase que fundamenta os sete minutos seguintes de seu discurso e que o coloca em uma perspectiva prática.

Cabe destacar que Cabe destacar que antes de qualquer coisa, um produto, sob a perspectiva de marketing, não é somente um conjunto de atributos funcionais - "what we're about isn't making boxes for people get their Jobs done" ("O que fazemos não é construir caixas para que as pessoas façam seu trabalho") (JOBS, 1997, tradução nossa), em uma crítica direta ao foco das empresas de computadores em atributos como velocidade, armazenamento e

\footnotetext{
${ }^{68}$ Essa frase de Jobs é uma renovação da clássica frase de Henri Ford "If had asked people what they wanted, they would have said faster horses" ("Se eu tivesse perguntado às pessoas o que elas queriam, elas teriam dito cavalos mais rápidos", tradução nossa). Maiores informações disponíveis em: https://hbr.org/2011/08/henry-ford-neversaid-the-fast. Acesso em: 28 mar. 21.

69 JOBS, Steve. Think different. Palestra. $1997 \quad(7 \quad$ min). Disponível em: https://www.youtube.com/watch?v=keCwRdbwNQY. Acesso em: 15 fev. 2021.
} 
taxas de atualização. O discurso de Jobs gira em torno da necessidade de as empresas saberem seu propósito em termos mais abstratos e de convertê-lo em forma de ofertas que tenham valor para as pessoas, que correspondam a seus sonhos e desejos mais íntimos: "what we have [Apple] is something that I'm very moved by: it honors those people who have changed the world" ("o que nós temos [Apple] é algo que me emociona muito: algo que honra aquelas pessoas que mudaram o mundo", tradução nossa) (JOBS, 1997), já estabelecendo um valor que será direcionado a um público que pensa dessa maneira.

Ao afirmar que, se todas as pessoas que mudaram o mundo ainda estivessem entre nós e tivessem tido a chance de usar um computador, "it would have been a Mac" ("teria sido um Mac", tradução nossa) (JOBS, 1997), Jobs faz uma ligação direta com as pessoas que também querem mudar o mundo e as incentiva a comprarem o produto que pode viabilizar ou facilitar tal feito. Ou seja, Jobs entendia a necessidade de compreender seu público para criar seus produtos, mas não se tratava apenas de uma compreensão superficial ou funcionalista que envolvia abordagens de pesquisa de marketing do tipo "você gosta da característica X ou Y do meu produto?"

Em correspondência às empresas desenvolvedoras entrevistadas, o marketing deve ser entendido como um potencializador da criatividade e não como um conjunto isolado de instrumentos de propaganda, além de valores mais atrelados a um posicionamento de qualidade, de criatividade artística ou de preocupação social. 


\section{CONCLUSÕES, LIMITAÇÕES E ESTUDOS FUTUROS}

O presente trabalho teve como objetivo principal elencar, descrever e qualificar grandes desafios que as micro e pequenas empresas desenvolvedoras brasileiras de jogos digitais precisam superar para melhorar sua gestão de marketing e, por consequência, direcionar as próximas fases de crescimento, motivadas pela falta de conhecimento mais profundo acerca da forma, dos métodos e dos processos envolvidos neste contexto.

A pesquisa não partiu de nenhuma hipótese previamente definida, pois os estudos identificados sobre o segmento tangenciavam a gestão de marketing sob alguns aspectos específicos - alguns, inclusive, desatualizados em termos de novas tecnologias e tendências, não as contemplando de forma abrangente, conforme se estava propondo. Essa constatação em si já seria uma justificativa para a realização do presente trabalho, no entanto, houve outro aspecto: poucos estudos abordavam as micro e pequenas empresas com foco na gestão de marketing. Somando-se essas questões, formaram-se camadas de filtros que deixaram a busca cada vez menos promissora: a busca por gestão de marketing em micro e pequenas empresas brasileiras desenvolvedoras de jogos digitais, a qual retornou alguns resultados, mas insuficientes para a resolução do problema de pesquisa e para atingir os objetivos propostos.

Assim, foi empreendido um esforço de exploração, de caráter qualitativo, para coletar dados primários por meio de entrevistas em profundidade realizadas com 10 (dez) sóciosproprietários de micro e pequenas empresas brasileiras desenvolvedoras de jogos digitais, que ocupam cargos executivos, e com outros 2 (dois) representantes de empresas de maior porte, em posições de liderança, as quais foram classificadas como outliers e, então, utilizadas como base de comparação nas análises.

Ao serem aplicadas as técnicas de análise, foi constatada a necessidade de separar 1 (uma) das 10 (dez) entrevistas do grupo de micro e pequenas empresas, passando também essa a ser considerada outlier, por ter demonstrado elevado nível de maturidade de gestão de marketing em função de sua finalidade e de seu conteúdo. Dessa forma, também essa empresa passou a ser utilizada como base de comparação assim como as empresas de maior porte, somando, então, três empresas outliers.

A análise de dados lançou mão de métodos da análise de conteúdo, mais especificamente da análise temática do conteúdo. Apesar de sua natureza qualitativa, que leva em consideração os significados, a contextualização e a inferência sobre o conteúdo avaliado, em alguns momentos, para melhor direcionamento do foco, foi preciso contar com o suporte de técnicas 
quantitativas. Mesmo assim, a pesquisa foi definida como qualitativa por não contemplar requisitos amostrais e de representatividade típicos de estudos quantitativos.

Esses procedimentos de coleta, tratamento e análise de dados elucidaram as visões estratégicas e as percepções de marketing que são a base dos encaminhamentos táticos e operacionais de gestão tidos como os mais críticos para os entrevistados: o player, nas fases de conceito e manutenção; o produto, nas fases de conceito e de acompanhamento; a promoção, na fase de lançamento; o preço, na fase de planejamento; e o somatório dos demais aspectos de gestão que envolvem as pessoas, os processos, a praça, a marca e o mercado, além da incipiente e promissora gestão da inteligência de marketing. Também foram realizados comparativos com a realidade de empresas de maior porte e/ou maior maturidade em termos de gestão de marketing.

A partir dessa base de análises, foi possível concluir que há uma série de desafios a serem superados, mas há um conjunto específico que pode ser priorizado pelas empresas em questão e que, eventualmente, pode ser um caminho para o desenvolvimento de uma gestão de marketing sustentável. Trata-se de desafios oriundos de inferências e de um trabalho de síntese do autor, com base nos aprendizados acumulados pelas análises realizadas, que levaram em consideração, inclusive, sua experiência acadêmica e mercadológica. Os 5 (cinco) desafios foram descritos no subitem 5.4 GRANDES DESAFIOS DA GESTÃO DE MARKETING e estão brevemente descritos a seguir.

Desafio 1 - Ir além do "P” de promoção: a visão de marketing das empresas precisa ir além do "P" de Promoção e passar a contemplar os outros "Ps" do Mix de Marketing, de modo a contar com uma estratégia de marketing abrangente, coerente e que reflita seu posicionamento de mercado em todas as frentes.

Desafio 2 - Engajar e manter a base de jogadores: é crucial uma vez que os investimentos necessários para elaborar um conceito, desenvolver o jogo e arcar com todos os riscos de lançamento são muito elevados para que as empresas possam renunciar a um ativo com potencial de retorno financeiro de longo prazo por meio da fidelização dos jogadores.

Desafio 3 - Impactar mais eficientemente os públicos potenciais: para ter uma base crescente de usuários é necessário impactar o maior número possível de potenciais jogadores. Esse movimento pode ser realizado pelas atuais práticas de relações públicas, mas potencializado pela adesão de novas tecnologias e de ferramentas de publicidade online.

Desafio 4 - Converter dados em inteligência de marketing: o processo de tomada de decisão de marketing pode ser aprimorado a partir do uso sistematizado e profissional de dados, processados e analisados com objetivos de marketing claros e alcançáveis. Para isso, é 
necessário superar as barreiras que impedem a transformação de dados em inteligência de marketing.

Desafio 5 - atender aos anseios do mercado sem perder a essência: o marketing deve ser incorporado à organização não simplesmente como um conjunto de ferramentas e táticas de persuasão de jogadores, mas como um guia de valores que se conecta aos desejos e às necessidades mais íntimas de seu público. Isso possibilitará o atendimento dos anseios do mercado sem que a empresa precise renunciar às suas essências artísticas, de qualidade de desenvolvimento ou de finalidades sociais.

Esses pontos foram denominados desafios, pois, para que as empresas possam priorizálos em sua gestão de marketing, será necessário romper barreiras típicas de micro e pequenas empresas como a falta de recursos financeiros, de conhecimento, de processos, de pessoas, de suporte público e privado, dentre outras. Para tanto, se aposta no desenvolvimento tecnológico, nas iniciativas de desenvolvimento do setor e em iniciativas de autoridades competentes.

Como limitação para o presente estudo aponta-se que, em função do método empregado, ficou subentendida a impossibilidade de inferir os resultados e as conclusões para todo o universo estudado, mesmo tendo havido grande preocupação em representar as características de maior proporção em um procedimento amostral que foi além da conveniência.

Também se aponta como limitação a coleta de dados ter sido realizada sob uma única perspectiva, sob o ponto de vista de líderes e de sócios-proprietários de empresas desenvolvedoras, sendo que, eventualmente, poderia ter sido complementada ou confrontada com visões de colaboradores em cargos de caráter tátil ou operacional ou até mesmo de outros agentes da indústria.

Além disso, não foram considerados nem os dados financeiros, nem os planos e registros de outras ações que as empresas analisadas possuíssem para que uma visão mais objetiva e mais independente das declarações dos entrevistados pudesse ter sido consolidada. Os dados que caracterizam as empresas como seu porte, o número de colaboradores e outras informações básicas foram oriundos de meios públicos ou de declaração dos próprios entrevistados, pois, por questões de políticas de sigilo e de privacidade das empresas, não foi possível obter outros níveis de detalhes.

No entanto, mesmo os dados até então coletados já permitem expandir os horizontes de análise contemplando aspectos narrativos, linguísticos, sentimentais e outros, mas iriam além da proposta de análise temática de conteúdo, extrapolando demasiadamente o escopo proposto. Sendo assim, deixam margem para alocação de tais esforços em estudos futuros. Ademais, dados ainda não coletados, de natureza quantitativa, descritiva ou confirmatória, poderiam 
possibilitar a realização de levantamentos representativos da Indústria de Jogos Digitais, fornecendo um panorama ampliado da gestão de marketing.

Por se tratar de um estudo exploratório, foram levantados alguns questionamentos que podem servir de base para hipóteses a serem respondidas em eventuais estudos futuros, tais como: Esses desafios aplicam-se a todo o universo estudado? Os desafios encontrados são exclusivos da Indústria de Jogos Digitais ou também são aplicáveis a outras Indústrias Criativas ou a micro e pequenas empresas de forma geral? A superação desses desafios implicaria, de fato, na melhoria da gestão de marketing ou há outros ainda a serem descobertos? Há uma ordem eficaz de resolução desses desafios que traga uma boa relação custo/benefício para tais empresas? Quais seriam as melhores formas de superar os desafios de modo a não comprometer a sobrevivência financeira das empresas?

Enfim, esses são alguns questionamentos dentre tantos outros que não foram possíveis de serem abordados na presente dissertação devido ao recorte estabelecido, mas que podem fazer parte de um conjunto de estudos sobre a temática proposta sob outras perspectivas, abordagens e formas de análise, visando ao avanço do conhecimento científico e ao desenvolvimento mercadológico e social desta importante e promissora Indústria nacional, a de Jogos Digitais, sob o ponto de vista da gestão de marketing.

Espera-se, contudo, que a presente dissertação venha a contribuir com a Academia, de modo a inspirar e a servir de base para novos estudos que venham a ser realizados (de caráter exploratório, descritivo ou confirmatório), lançando aspectos a serem mensurados, e premissas e hipóteses a serem testadas em perspectivas mais amplas; e com a Indústria, apresentando soluções de negócios e formas de organização e de financiamento do setor que venham a colocar as empresas desenvolvedoras brasileiras de jogos digitais nos holofotes do mundo. 


\section{REFERÊNCIAS BIBLIOGRÁFICAS}

ABBAS, N.; GRAVELL, A. M.; WILLS, G. B. Historical Roots of Agile Methods: Where Did "Agile Thinking" Come From? Lecture Notes in Business Information Processing. Berlin, Springer, 2008.

ABBASI, M.; VASSILOPOULOU, P.; STERGIOULAS, L. Technology roadmap for the Creative Industries. Creative Industries Journal, v. 10, n. 1, p. 40-58, 28 set. 2016. Disponível em: https://doi.org/10.1080/17510694.2016.1247627. Acesso em: set. 2020

AKGOZ, E. O. Pricing Strategies for Video Games. The Circular, 2019. Disponível em: http://thecircular.org/pricing-strategies-for-video-games/. Acesso em: 15 nov. 2020.

ALAIMO, C.; KALlinIKOS, J. Objects, Metrics and Practices: An Inquiry. IFIP International Federation for Information Processing 2018, Switzerland, p. 110-123, 2018. Disponível em: https://doi.org/10.1007/978-3-030-04091-8_9. Acesso em: ago. 2020

ALEEM, S.; CAPRETZ, L. F.; AHMED, F. A Digital Game Maturity Model (DGMM). Entertainment Computing, v. 17, p. 55-73, August 2016. Disponível em: https://10.1016/j.entcom.2016.08.004. Acesso em: out. 2020

ALFORD, P.; PAGE, S. J. Marketing technology for adoption by small business. The Service Industries Journal, v. 35, n. 11-12, p. 655-669, 20 May 2015. Disponível em: https://doi.org/10.1080/02642069.2015.1062884. Acesso em: nov. 2020

AMA - American Marketing Association. Definitions of Marketing. 2017. Disponível em: https://www.ama.org/the-definition-of-marketing-what-is-marketing/. Acesso em: 12 nov. 2020.

AMA - American Marketing Association. What is Digital Marketing? 2020. Disponível em: https://www.ama.org/pages/what-is-digital-marketing/. Acesso em: 16 nov. 2020.

ANDRIANI, M. et al. Aligning business process maturity level with SMEs growth in Indonesian fashion industry. International Journal of Organizational Analysis, v. 26, n. 4, p. 709-727, 3 September 2018. Disponível em: https://doi.org/10.1108/IJOA-08-2017-1215. Acesso em: nov. 2020.

ANDRONICO, M. Digital vs. Physical Games: What's Right For You? Toms Guide, 2017. Disponível em: https://www.tomsguide.com/us/digital-vs-physical-games,news-26164.html. Acesso em: 17 nov. 2020.

BARDIN, L. Análise de Conteúdo. São Paulo: Grupo Almedina, 2011.

BEAVER, O. et al. Finding a needle in Haystack: Facebook's photo storage. USENIX Symposium on Operating Systems Design and Implementation (OSDI). [S.1.]: Facebook Research, p. 1-14, 2010.

BENDASSOLLI, P. F. et al. Indústrias Criativas: Definição, Limites e Possibilidades. Revista de Administração de Empresas, v. 49, n. 1, p. 10-18, janeiro/março 2009. 
BNDES - BANCO NACIONAL DO DESENVOLVIMENTO. Classificação de porte dos clientes, 2021. Disponível em: https://www.bndes.gov.br/wps/portal/site/home/financiamento /guia/quem-pode-ser-cliente/. Acesso em: 20 mar. 2021.

BOBOLOGY. What is Cross-Platform Software? 2020. Disponível em: https://www.bobology.com/public/What-is-CrossPlatform-Software.cfm. Acesso em: 5 nov. 2020.

BOOMS, B. H.; BITNER, M. J. Marketing strategies and organization structures for service firms. Marketing of Services, Chicago IL, p. 47-51, 1981. Disponível em: https://ci.nii.ac.jp/naid/10030529304/\#cit. Acesso em: nov. 2020.

BORDEN, N. H. The Concept of the Marketing Mix. Journal of Advertising Research, p. 27, 4 June 1964. Disponível em: http://www.guillaumenicaise.com/wpcontent/uploads/2013/10/Borden-1984_The-concept-of-marketing-mix.pdf. Acesso em: nov. 2020 .

BRAUN, V.; CLARKE, V. Using thematic analysis in psychology. Qualitative Research in Psychology, v. 3, n. 2, p. 77-101, 21 July 2008. Disponível em: https://doi.org/10.1191/1478088706qp063oa. Acesso em: out. 2020.

BRKLJAČIĆ, T. et al. Games We Play: Wellbeing of Players of Live and Digital Games. [S.1.]: IGI Global, 2019.

BROCATO, D. Push and Pull Marketing Strategies. In: SHETH, J. N.; MALHOTRA, N. K. Wiley International Encyclopedia of Marketing. New York: John Wiley \& Sons, 2010.

BRUNSWICK, G. J. A Chronology of the Definition of Marketing. Journal of Business \& Economics Research, v. 12, n. 2, p. 105-114, 2014. Disponível em: https://clutejournals.com/index.php/JBER/article/view/8523/8530. Acesso em: out. 2020.

BURGER-HELMCHEN, T. Are Users the Next Entrepreneurs? A Case Study on the Video Game Industry. Document de Travail, n. 2008-14, p. 1-25, 16 June 2008. Disponível em: https://dx.doi.org/10.2139/ssrn.1146531. Acesso em: nov. 2020.

BUSSAB, W. D. O.; MORETTIN, P. D. A. Estatística Básica. 6. ed. São Paulo: Saraiva, 2010.

CAMERER, C. F.; LOEWENSTEIN, G. Behavioral Economics: Past, Present, Future. Caltech.edu, 25 October, p. 1-61, 2002. Disponível em: https://authors.library.caltech.edu/22029/1/ribe239\%5B1\%5D.pdf. Acesso em: 11 nov. 2020.

CANALTECH. O que é MMO? 2012. Disponível em: https://canaltech.com.br/games/O-quee-MMO/. Acesso em: 13 out. 2020.

CASTELLS, M. A Sociedade em Rede. 20. ed. São Paulo: Paz \& Terra, 2019.

CASTRO, T. D. Nos anos 1990, propagandas toscas na TV vendiam facas com 52 anos de garantia. Notícias da TV UOL, 2019. Disponível em: https://noticiasdatv.uol.com.br/noticia/televisao/nos-anos-1990-propagandas-toscas-vendiamfacas-oculos-e-muito-mais-na-tv-30264. Acesso em: 12 nov. 2020. 
CASWELL, T. Google Stadia is a total failure. Here's how it can be fixed. Inputmag.com, 2020. Disponível em: https://www.inputmag.com/gaming/google-stadia-can-be-saved-hereshow. Acesso em: 4 nov. 2020.

CHAFFEY, D. Applying organizational capability models to assess the maturity of digitalmarketing governance. Journal of Marketing Management, v. 26, n. 3-4, p. 187-196, 29 April 2010. Disponível em: https://doi.org/10.1080/02672571003612192. Acesso em: nov. 2020.

CHANDLER, H. M. Manual de Produção de Digitais. 2. ed. Porto Alegre: Bookman, 2012.

CHEN, M.-H.; CHANG, Y.-Y.; LEE, C.-Y. Creative entrepreneurs' guanxi networks and success: Information and resource. Journal of Business Research, v. 68, n. 4, p. 900-905, April 2015. Disponível em: https://doi.org/10.1016/j.jbusres.2014.11.049. Acesso em: nov. 2020.

CHERNEY, M. A. This violent videogame has made more money than any movie ever. Market Watch, 2018. Disponível em: https://www.marketwatch.com/story/this-violent-videogamehas-made-more-money-than-any-movie-ever-2018-04-06. Acesso em: 6 dez. 2020.

CHIAVENATO, I. Empreendedorismo: dando asas ao espírito empreendedor: empreendedorismo e viabilização de novas empresas: um guia compreensivo para iniciar e tocar seu próprio negócio. 2. ed. São Paulo: Saraiva, 2008.

CLEMENT, J. Number of monthly active users (MAU) of Counter-Strike: Global Offensive (CS:GO) worldwide as of February 2020. Statista, 2021. Disponível em: https://www.statista.com/statistics/808922/csgo-users-number/. Acesso em: 1 fev. 2021.

CRAWFORD, J. K. The Project Management Maturity Model. Information Systems Management, v. 23, n. 4, p. 50-58, 21 December 2006. Disponível em: https://doi.org/10.1201/1078.10580530/46352.23.4.20060901/95113.7. Acesso em: nov. 2020.

CRESWELL, J. W. Investigação qualitativa e projeto de pesquisa: escolhendo entre cinco abordagens. 3. ed. Porto Alegre: Penso, 2014.

CSIKSZENTMIHALYI, M.; CSIKSZENTMIHALYI, I. S. Optimal Experience: Psychological Studies of Flow in Consciousness. Cambridge: Cambridge University Press, 1992.

CWALINA, W.; FALKOWSKI, A.; NEWMAN, B. I. Political Marketing: Theoretical and Strategic Foundations. 2. ed. New York: M.E. Sharpe, 2011.

DAVENPORT, T. H.; PATIL, D. J. Data Scientist: The Sexiest Job of the $21^{\text {st }}$ Century. Harvard Business Review, October 2012. Disponível em: https://hbr.org/2012/10/datascientist-the-sexiest-job-of-the-21st-century. Acesso em: 23 nov. 2020.

DEALESSANDRI, M. How to get a job as a community manager in games. Game Industry, 2020. Disponível em: https://www.gamesindustry.biz/articles/2020-11-09-how-to-get-a-jobas-a-community-manager-in-games. Acesso em: 30 nov. 2020.

DEPARTMENT FOR DIGITAL, CULTURE, MEDIA \& SPORT. Creative Industries Mapping Documents 2001. Gov.uk, 9 April 2001. Disponível em: https://www.gov.uk/government/publications/creative-industries-mapping-documents-2001. Acesso em: 1 mar. 2021. 
DICIONÁRIO ETIMOLÓGICO. Origem da palavra marketing. 2020. Disponível em: https://www.dicionarioetimologico.com.br/marketing/. Acesso em: 10 nov. 2020.

DICIONÁRIO ONLINE DE PORTUGUÊS. Significado de Marketing. 2020. Disponível em: https://www.dicio.com.br/marketing/. Acesso em: 10 nov. 2020.

DURKIN, K. Videogames and Young People with Developmental Disorders. Review of General Psychology, v. 14, n. 2, p. 122-140, 1 jun. 2010. Disponível em: https://doi.org/10.1037/a0019438. Acesso em: nov. 2020.

ESPOSITO, N. A Short and Simple Definition of What a Videogame Is. Digital Games Research Conference 2005. Changing Views: Worlds in Play. Vancouver: [s.n.], p. 16-20, 2005.

EVERITT, B.; LANDAU, S.; LEESE, M. Cluster Analysis. 4. ed. London: Arnold, 2001.

FEA USP. Informações Gerais sobre o Programa. 2020. Disponível em: https://www.fea.usp.br/administracao/mestrado-profissional/informacoes-gerais-sobre-oprograma. Acesso em: 14 out. 2020.

FERRELL, O. C.; LUCAS-JR, G. H. An Evaluation of Progress in the Development of a Definition of Marketing. Journal of the Academy of Marketing Science, v. 15, n. 3, p. 1223, October 1987. Disponível em: https://doi.org/10.1007/BF02722167. Acesso em: nov. 2020.

FONTANELLA, B. J. B. et al. Amostragem em pesquisas qualitativas: proposta de procedimentos para constatar saturação teórica. Cadernos de Saúde Pública, Rio de Janeiro, v. 27, n. 2, p. 389-394, fevereiro 2011. Disponível em: https://doi.org/10.1590/S0102311X2011000200020 . Acesso em: out. 2020.

FORD, H.; CROWTHER, S. My Life and Work. New York: Garden City Publishing Company Inc, 1922.

FRAKENTHAL, R. 6 exemplos de posicionamento de marca bem-sucedidos. Mind Miners, 2018. Disponível em: https://mindminers.com/blog/exemplos-posicionamento-de-marca/. Acesso em: 13 nov. 2020.

FRASER, M. T. D.; GONDIM, S. M. G. Da fala do outro ao texto negociado: discussões sobre a entrevista na pesquisa qualitativa. Paidéia, Ribeirão Preto, v. 14, n. 28, p. 139-152, agosto 2004. Disponível em: https://doi.org/10.1590/S0103-863X2004000200004. Acesso em: nov. 2020.

FRIED, I. Rovio Passes a Billion Angry Birds Downloads, Still Mulling IPO. Allthingsd, 2012. Disponível em: http://allthingsd.com/20120509/rovio-ceo-when-to-go-public-is-up-to-dadother-owners/. Acesso em: 1 mar. 2021.

FROW, P.; PAYNE, A. Customer Relationship Management: A Strategic Perspective. Journal of business market management, v. 3, p. 7-27, 17 February 2009. Disponível em: https://doi.org/10.1007/s12087-008-0035-8. Acesso em: nov. 2020.

GABOX. Pac-Man - Videogame History \#1 - Retro Review. Steemit, 2018. Disponível em: https://steemit.com/gaming/@gabox/pac-man-videogame-history-1-retro-review. Acesso em: 9 mar. 2021. 
GAEDEKE, R. M.; TOOTELIAN, D. H. Marketing principles and applications. St. Paul, MN: West Publishing Company, 1983.

GAME ACE. Mobile, Console or VR: Game Development Cost Explained. Game Ace, 2017. Disponível em: https://game-ace.com/blog/mobile-console-vr-game-development-costexplained/. Acesso em: 8 nov. 2020.

GAME DESIGNING. 10 Trends in Game Design. 2020. Disponível em: https://www.gamedesigning.org/gaming/trends/. Acesso em: 7 out. 2020.

GIL, R.; WARZYNSKI, F. Vertical Integration, Exclusivity, and Game Sales Performance in the US Video Game Industry. The Journal of Law, Economics, and Organization, v. 31, n. 1, p. 143-168, 1 August 2015. Disponível em: https://doi.org/10.1093/jleo/ewu006. Acesso em: ago. 2020.

GILMORE, A.; GALLAGHER, D.; HENRY, S. E-marketing and SMEs: operational lessons for the future. European Business Review, v. 19, n. 3, 22, p. 234-247, May 2007. Disponível em: https://doi.org/10.1108/09555340710746482. Acesso em: set. 2020.

GOMES, N. D. Publicidade ou propaganda? É isso aí! Revista FAMECOS, Porto Alegre, v. 16, p. 111-112, dezembro 2001. Disponível em: https://revistaseletronicas.pucrs.br/ojs/index.php/revistafamecos/article/view/3142/2413.

Acesso em: ago. 2020.

GONZÁLEZ-GONZÁLEZ, C.; BLANCO-IZQUIERDO, F. Designing social videogames for educational uses. Computers \& Education, v. 58, n. 1, p. 250-262, January 2012. Disponível em: https://doi.org/10.1016/j.compedu.2011.08.014. Acesso em: nov. 2020.

GOOD READS. Steve Jobs - Quotes - Quotable Quote. 2021. Disponível em: https://www.goodreads.com/quotes/988332-some-people-say-give-the-customers-what-theywant-but. Acesso em: 10 mar. 2021.

GOOGLE. Programmatic. Think With Google, 2020a. Disponível em: https://www.thinkwithgoogle.com/marketing-strategies/programmatic/. Acesso em: 19 nov. 2020.

GOOGLE. Apps. Among Us. Google Play, 2020b. Disponível em: https://play.google.com/store/apps/details?id=com.innersloth.spacemafia. Acesso em: 20 nov. 2020.

GOTTSCHALK, P.; SOLLI-SAETHER, H. Maturity model for IT outsourcing relationships. Industrial Management \& Data Systems, v. 106, n. 2, p. 200-212, 1 February 2006. Disponível em: https://doi.org/10.1108/02635570610649853. Acesso em: out. 2020.

GOUGH, C. Call of Duty: Warzone player count 2020. Statista, 2020. Disponível em: https://www.statista.com/statistics/1110000/call-of-duty-warzone-players/. Acesso em: 15 out. 2020.

GRAFT, K. 500 games launched per day on iOS last year (and other digital sales facts). Gamasutra, 2 March 2015. Disponível em: https://www.gamasutra.com/view/news/237811/500_games_launched_per_day_on_iOS_last_ year_and_other_digital_sales_facts.php. Acesso em: 1 mar. 2021. 
GRIFFITHS, M. The educational benefits of videogames. Education and Health, v. 20, n. 3, p. 47-51, 2002.

HAIR-JR, J. F. et al. Fundamentos de Métodos de Pesquisa em Administração. [S.1.]: Bookman, 2005.

HARTMANN, T. The "Moral Disengagement in Violent Videogames" model. Game Studies. The International Journal of Computer Game Research, v. 17, n. 2, 31 December 2017. Disponível em: http://gamestudies.org/1702/articles/hartmann. Acesso em: nov. 2020

HENNIG-THURAU, T.; HOUSTON, M. B.; SRIDHAR, S. Can good marketing carry a bad product? Evidence from the motion picture industry. Marketing Letters, v. 17, p. 205-219, 2006. Disponível em: https://doi.org/10.1007/s11002-006-7416-0. Acesso em: ago. 2020.

HILLSON, D. A. Towards a Risk Maturity Model. The International Journal of Project \& Business Risk Management, v. 1, n. 1, p. 35-45, 1997. Disponível em: https://riskdoctor.com/wp-content/uploads/2020/06/RMM-IJPBRM-Mar97.pdf. Acesso em: out. 2020.

HISRICH, R. D.; PETERS, M. P.; SHEPERD, D. A. Empreendedorismo. 9. ed. Porto Alegre: AMGH, 2014.

HOLST, A. Unit sales of Nintendo's home consoles from 1997 to 2020 (in millions). Statista, 2020. Disponível em: https://www.statista.com/statistics/227012/lifetime-unit-sales-ofnintendos-home-consoles/. Acesso em: 16 out. 2020.

IQBAL, M. Pokémon GO Revenue and Usage Statistics. Business of Apps, 2020. Disponível em: https://www.businessofapps.com/data/pokemon-go-statistics/\#4. Acesso em: 10 nov. 2020.

JENSON, J.; CASTELL, S. D. Tipping Points: Marginality, Misogyny and Videogames. Journal of Curriculum Theorizing, v. 29, n. 2, 2013. Disponível em: https://journal.jctonline.org/index.php/jct/article/view/474. Acesso em: set. 2020.

JOBS, Steve. Think different. Palestra. 1997 (7 min). Disponível em: https://www.youtube.com/watch?v=keCwRdbwNQY. Acesso em: 15 fev. 2021.

KEEFE, L. M. What Is the Meaning of Marketing? Marketing News, p. 17-18, 15 September 2004.

KIM, H. S.; HOLlingShEAD, S.; WOHL, M. J. A. Who Spends Money to Play for Free? Identifying Who Makes Micro-transactions on Social Casino Games (and Why). Journal of Gambling Studies, v. 33, n. 2, p. 525-538, 30 June 2016.

KOTLER, P. Marketing Management: Analysis, Planning, and Control. NJ: Prentice-Hall, 1967.

KOTLER, P.; ARMSTRONG, G. Princípios de Marketing. São Paulo: Pearson Prentice Hall, 2007.

KOTLER, P.; KELlER, K. L. Administração de Marketing. 12. ed. São Paulo: Pearson Prentice Hall, 2006. 
KRÜGER, F. L.; MOSER, G. O Marketing dos Jogos Eletrônicos. Trabalho apresentado à Sessão de Temas Livres do XXVIII Congresso Brasileiro de Ciências da Comunicação. Florianópolis - SC: [s.n.], 2005. p. 1-15.

LARGHI, N. Brasil é o $13^{\circ}$ maior mercado de games do mundo e o maior da América Latina. Valor Investe, 30 julho 2019. Disponível em: https://valorinveste.globo.com/objetivo/empreenda-se/noticia/2019/07/30/brasil-e-o-13omaior-mercado-de-games-do-mundo-e-o-maior-da-america-latina.ghtml. Acesso em: 7 nov. 2020.

LAUTERBORN, R. B. New Marketing Litany: Four Ps Passe: C-Words take over. Advertising Age, v. 61, n. 41, 1990.

LEVITT, T. Marketing Myopia, v. 4, n. 4, 59-80, 1984. Disponível em: https://doi.org/10.1300/J111V04N04_07. Acesso em: set. 2020.

LO and Behold: Reviewers of the Connected World. Direção: Werner Herzog. USA: Netflix, 2016. Documentário (98 min.).

LU, A. S. et al. A Systematic Review of Health Videogames on Childhood Obesity Prevention and Intervention. Games for Health Journal, v. 2, n. 3, p. 131-141, 11 June 2013. Disponível em: http://doi.org/10.1089/g4h.2013.0025. Acesso em: out. 2020.

LYNCH, K. Confirmed: Grand Theft Auto 5 breaks 6 sales world records. Guinnes World Records, 8 October 2013. Disponível em: https://www.guinnessworldrecords.com/news/2013/10/confirmed-grand-theft-auto-breakssix-sales-world-records-51900. Acesso em: 6 out. 2020.

MALHOTRA, N. K. Pesquisa de Marketing: uma orientação aplicada. 4. ed. Porto Alegre: Bookman, 2006.

MARSHALL, M. N. Sampling for qualitative research. Family Pratice, Oxford, v. 13, n. 6, p. 522-526, 1 December 1996. Disponível em: https://doi.org/10.1093/fampra/13.6.522. Acesso em: set. 2020.

MATCH2ONE. What is Programmatic Advertising? The Must-Have 2021 Guide. Match2One, 2021. Disponível em: https://www.match2one.com/blog/what-is-programmaticadvertising/\#DMP_vs_DSP. Acesso em: 30 jan. 2021.

MAZZON, J. A. Formulação de um modelo de avaliação e comparação de modelos em marketing. 1978. Dissertação (Mestrado em Administração) - Faculdade de Economia e Administração, Universidade de São Paulo, São Paulo, 1978.

MAZZON, J. A. Using the Methodological Association Matrix in Marketing Studies. Brazilian Journal of Marketing, v. 17, n. 5, 21 August 2018. Disponível em: https://doi.org/10.5585/bjm.v17i5.4175. Acesso em: set. 2020.

MINC (MINISTÉRIO DA CULTURA). Segundo Censo da Indústria Brasileira de Jogos Digitais. Governo Federal, Brasília. 2018.

MINISTÉRIO DA SAÚDE. Painel Coronavírus. Coronavírus Brasil, 2020. Disponível em: https://covid.saude.gov.br/. Acesso em: 1 dez. 2020. 
MOI, L.; CABIDDU, F. Leading digital transformation through an Agile Marketing Capability: the case of Spotahome. Journal of Management and Governance, p. 1-33, 4 October 2020. Disponível em: https://doi.org/10.1007/s10997-020-09534-w. Acesso em: out. 2020.

MOLINS-RUANO, P. et al. Designing videogames to improve students' motivation. Computers in Human Behavior, v. 31, p. 571-579, February 2014.

MONTINI, A. Pandemia matou a crença em muitos setores de que home office não funciona. UOL, 2020. Disponível em: https://www.uol.com.br/tilt/colunas/alessandramontini/2020/05/14/pandemia-matou-a-crenca-em-muitos-setores-de-que-home-office-naofunciona.htm. Acesso em: 25 nov. 2020.

MOREIRA, W. Revisão de Literatura e Desenvolvimento Científico: conceitos e estratégias para confecção. Lorena: UFG, v. 1, 2004.

MULROW, C. D. Systematic Reviews: Rationale for systematic reviews. BMJ Clinical Research, 309, n. 6954, p. 597-599, 3 September 1994. Disponível em: https://www.researchgate.net/deref/http\%3A\%2F\%2Fdx.doi.org\%2F10.1136\%2Fbmj.309.69 54.597. Acesso em: set. 2020.

NAGLE, T. T.; HOGAN, J. E.; ZALE, J. The Strategy and Tactics of Pricing. 5. ed. [S.1.]: Routledge, 2016.

NATIONAL MUSEUM OF PLAY. Video Game History Timeline. The Strong, 2020. Disponível em: https://www.museumofplay.org/about/icheg/video-game-history/timeline. Acesso em: 7 out. 2020.

NEWZOO. Newzoo Global Esports Market Report 2020 | Light Version. Newzoo. [S.1.], p. 135. 2020a.

NEWZOO. Platform Newzoo - Explorer, 2020b. Disponível em: https://platform.newzoo.com/. Acesso em: 6 nov. 2020.

NEWZOO. Explorer - Brazil Market Games. Platform Newzoo, 2020c. Disponível em: https://platform.newzoo.com/explorer/market/Brazil/games. Acesso em: 9 nov. 2020.

NIU, Y.; WANG, C. L. Revised Unique Selling Proposition: Scale Development, Validation, and Application. Journal of Promotion Management, v. 22, n. 6, p. 874-896, 2 September 2016. Disponível em: https://doi.org/10.1080/10496491.2016.1214209. Acesso em: out. 2020.

PBS.ORG. Pokémon GO uses augmented reality — or does it? Pbs.org, 2016. Disponível em: https://www.pbs.org/newshour/science/pokemon-go-uses-augmented-reality. Acesso em: 2 nov. 2020.

PETERS, J. The different strategies of Microsoft and Sony's next-generation consoles. The Verge, 4 November 2020. Disponível em: https://www.theverge.com/2020/11/4/21548077/microsoft-sony-next-generation-consolesstrategies-approaches. Acesso em: 14 nov. 2020.

POOLEY, J. 10 Reasons Watch Dogs Is a Huge Disappointment, 27 May 2014. Disponível em: https://whatculture.com/gaming/10-reasons-watch-dogs-huge-disappointment?. Acesso em: 17 nov. 2020. 
QRS INTERNATIONAL. Using NVivo. Nvivo - QRS International, 2020. Disponível em: https://help-nv.qsrinternational.com/20/win/Content/concepts-strategies/using-nvivo-forqualitative-research.htm. Acesso em: 22 nov. 2020.

RAGE ZONE. MMO Strong: 5 Online Games Still Popular in 2020. Rage Zone, 2 February 2020. Disponível em: https://ragezone.com/2020/02/02/mmo-strong-5-online-games-stillpopular-in-2020/. Acesso em: 14 out. 2020.

RAHMANI, E.; BOREN, S. A. Videogames and Health Improvement: A Literature Review of Randomized Controlled Trials. Games for Health Journal, v. 1, n. 5, p. 331-341, 5 October 2012. Disponível em: https://doi.org/10.1089/g4h.2012.0031. Acesso em: ago. 2020.

RATHMELL, J. M. What is Meant by Services? Journal of Marketing, v. 30, n. 4, p. 32-36, 1 October 1966. Disponível em: https://doi.org/10.1177/002224296603000407. Acesso em: set. 2020.

REGAN, W. J. The Service Revolution. Journal of Marketing, v. 27, n. 3, p. 57-62, 1 July 1963. Disponível em: https://doi.org/10.1177/002224296302700312. Acesso em: out. 2020.

REINARTZ, W.; KRAFFT, M.; HOYER, W. D. The Customer Relationship Management Process: Its Measurement and Impact on Performance. Journal of Marketing Research, v. 41, n. 3, p. 293-305, 1 August 2004. Disponível em: https://doi.org/10.1509/jmkr.41.3.293.35991. Acesso em: out. 2020.

RIES, A.; TROUT, J. Posicionamento: a batalha por sua mente: como ser visto e ouvido em um mercado super competitivo. São Paulo: M. Books dos Brasil Ltda., 2009.

ROCKSTAR GAMES. Informação Geral. 2020. Disponível em: https://www.rockstargames.com/V/br/info. Acesso em: 6 out. 2020.

RONDANI, B. Bate-papo com Steve Blank sobre Henry Ford e Steve Jobs. Open Blog, 2013. Disponível em: http://blog.openstartups.net/bate-papo-com-steve-blank-sobre-henry-ford-esteve-jobs-por-bruno-rondani/. Acesso em: 10 mar. 2021.

ROSEMANN, M.; BRUIN, T. D. Towards a Business Process Management Maturity Model. European Conference on Information Systems (ECIS). [S.1.], [s.n.], p. 1-13, 2005.

ROSER, M.; RITCHIE, H.; ORTIZ-OSPINA, E. Internet. Our World in Data, 2020. Disponível em: https://ourworldindata.org/internet. Acesso em: 17 nov. 2020.

RUNCO, M. A.; JAEGER, G. J. The Standard Definition of Creativity. Creativity Research Journal, v. 24, n. 1, p. 92-96, 10 February 2012. Disponível em: https://doi.org/10.1080/10400419.2012.650092. Acesso em: out. 2020.

SAMOR, G. Wildlife, o unicórnio global brasileiro, já vale US\$ 1,3 bi. Brazil Journal, 5 December 2019. Disponível em: https://braziljournal.com/wildlife-o-unicornio-globalbrasileiro-ja-vale-us-13-bi\#:0alcance\%20global. Acesso em: 10 nov. 2020.

SCHERPENZEEL, A.; TOEPOEL, V. Recruiting a probability sample for an online panel: effects of contact mode, incentives and information. Public Opinion Quarterly, v. 76, n. 3, p. 470-490, 10 September 2012. Disponível em: https://doi.org/10.1093/poq/nfs037. Acesso em: out. 2020 . 
SCHROECK, M.; SHOCKLEY, R.; SMART, J. Analytics: the real-world use of big data: How innovative enterprises extract value from uncertain data. Executive Report. IBM Institute for Business Value and Said Business School at the University of Oxford. [S.1.]. 2012.

SCHWABER, K.; SUTHERLAND, J. The Scrum Guide. Agile Learning Labs, November 2020. Disponível em: https://agilelearninglabs.com/wp-content/uploads/2020/11/2020-ScrumGuide-US.pdf. Acesso em: 18 nov. 2020.

SCREEN SKILLS. What does a games publisher do? 2020. Disponível em: https://www.screenskills.com/careers/job-profiles/games/production/games-publisher/. Acesso em: 30 nov. 2020.

SEBRAE. O Plano de Marketing. 31 outubro 2021. Disponível em: https://www.sebrae.com.br/sites/PortalSebrae/galeriavideo/o-plano-demarketing,505d18bd7b847510VgnVCM1000004c00210aRCRD. Acesso em: 3 fev. 2021.

SEO, Y. Electronic sports: A new marketing landscape of the experience economy. Journal of Marketing Management, v. 29, n. 13-14, p. 1542-1560, 2013. Disponível em: https://doi.org/10.1080/0267257X.2013.822906. Acesso em: out. 2020.

SERRANO-LAGUNA, Á. et al. Application of Learning Analytics in educational videogames. Entertainment Computing, v. 5, p. 313-322, December 2014. Disponível em: https://doi.org/10.1016/j.entcom.2014.02.003. Acesso em: nov. 2020.

SHAIKH, A. et al. Implementation of a service platform for online games. Proceedings of the 3rd Workshop on Network and System Support for Games. Portland: [s.n.], p. 1-6, 2004.

SHAW, E. H.; JONES, D. G. B. A history of schools of marketing thought. Marketing Theory, v. 5, n. 3, p. 239-281, 1 September 2005. Disponível em: https://doi.org/10.1177/1470593105054898. Acesso em: out. 2020.

SHETH, J. N.; USLAY, C. Implications of the Revised Definition of Marketing: From Exchange to Value Creation. Journal of Public Plicy \& Marketing, v. 26, n. 2, p. 302-307, Fall 2007. Disponível em: https://doi.org/10.1509/jppm.26.2.302. Acesso em: out. 2020.

SHOSTACK, G. L. Breaking Free from Product Marketing. Journal of Marketing, v. 41, n. 2, p. 73-80, 1 April 1977.

SMITH, W. R. Product Differentiation and Market Segmentation as Alternative Marketing Strategies. Journal of Marketing, v. 21, n. 1, p. 3-8, 1 July 1956. Disponível em: https://doi.org/10.1177/002224295602100102. Acesso em: nov. 2020.

SREEJESH, S.; MOHAPATRA, S.; ANUSREE, M. R. Business Research Methods: an applied orientation. New York: Springer, 2013.

STEIN, M. I. Creativity and Culture. The Journal of Psychology, v. 36, n. 2, p. 311-322, 26 May 1953. Disponível em: https://doi.org/10.1080/00223980.1953.9712897. Acesso em: out. 2020.

STEWART, S. Video game industry silently taking over entertainment world. Ejinsight, 22 October 2019. Disponível em: https://www.ejinsight.com/eji/article/id/2280405/20191022video-game-industry-silently-taking-over-entertainment-world. Acesso em: 6 out. 2020. 
TAKAHASHI, D. Mobile game revenue grew 53\% to $\$ 11.9$ billion in Q1 2017. Venture Bear - VB, 13 April 2017. Disponível em: https://venturebeat.com/2017/04/13/worldwide-mobilegame-revenue-grew-53-to-11-9-billion-in-q1/. Acesso em: 17 nov. 2018.

THE DRUM. Is Facebook's Ads Manager a DSP? And how does its inventory stack up to other publishers? 18 April 2017. Disponível em: https://www.thedrum.com/industryinsights/2017/04/18/facebooks-ads-manager-dsp-and-howdoes-its-inventory-stack-up-other. Acesso em: 18 nov. 2020.

TROILO, G. Marketing In Creative Industries: Value, Experience and Creativity. New York: Macmillan Publishers Limited, 2015.

TSCHANG, T. Balancing the Tensions Between Rationalization and Creativity in the Video Games Industry. Organization Science, v. 18, n. 6, p. 989-100, November/December 2007. Disponível em: https://www.jstor.org/stable/25146154?seq=1. Acesso em: out. 2020.

TUCKER, F. Chapter 7.2 Game Industry Roles and Economics. Slide Player, 2016. Disponível em: https://slideplayer.com/slide/9347903/. Acesso em: 20 nov. 2020.

TURNER, D. W. Qualitative Interview Design: A Practical Guide for. The Qualitative Report, v. 15, n. 3, p. 754-760, May 2010. Disponível em: https://doi.org/10.46743/21603715/2010.1178. Acesso em: set. 2020.

VARADARAJAN, R. Strategic marketing and marketing strategy: domain, definition, fundamental issues and foundational premises. Journal of the Academy of Marketing Science, v. 38, p. 119-140, 28 April 2010. Disponível em: https://doi.org/10.1007/s11747-0090176-7. Acesso em: out. 2020.

VERKASALO, H. Behavioral COVID-19 Tracker. Verto Analytics, 17 July 2020. Disponível em: https://vertoanalytics.com/verto-analytics-behavioral-covid-19-tracker-bytracking-total-mobile-and-pc-time-spent-by-category-it-is-clear-that-pc-is-the-winner-againstmobile-in-not-only-gaining-but-also-retaining-online-us/. Acesso em: 1 mar. 2020.

VICTOR, M. Conheça a evolução dos jogos eletrônicos no Brasil e no mundo. Jornada Geek, 04 abril 2018. Disponível em: https://www.jornadageek.com.br/colunas/conheca-a-evolucaodos-jogos-eletronicos-no-brasil-e-no-mundo-pagina-7/. Acesso em: 7 out. 2020.

VILLANI, D. et al. Videogames for Emotion Regulation: a systematic review. Games for Health Journal, v. 7, n. 2, p. 85-99, 1 April 2018. Disponível em: https://doi.org/10.1089/g4h.2017.0108. Acesso em: nov. 2020.

WALLER, M. A.; FAWCETT, S. E. Data Science, Predictive Analytics, and Big Data: A Revolution That Will Transform Supply Chain Design and Management. Journal of Business Logistics, v. 34, n. 2, p. 77-84, 11 June 2013. Disponível em: https://doi.org/10.1111/jbl.12010. Acesso em: out. 2020.

WALLER, T. Marketing Strategies of Mobile Game Application Entrepreneurs. Walden Dissertations and Doctoral Studies, n. 1.809, 2015. Disponível em: https://scholarworks.waldenu.edu/dissertations/1809. Acesso em: ago. 2020.

WALlimAn, N. Métodos de Pesquisa. São Paulo: Saraiva, 2015. 
WATKINS, R.; MOLESWORTH, M. Attachment to Digital Virtual Possessions in Videogames. Research in Consumer Behavior, v. 14, p. 153-170, 22 November 2012. Disponível em: https://doi.org/10.1108/S0885-2111(2012)0000014012. Acesso em: set. 2020.

WIJMAN, T. Mobile Revenues Account for More Than 50\% of the Global Games Market as It Reaches \$137.9 Billion in 2018. Newzoo, 2018. Disponível em: https://newzoo.com/insights/articles/global-games-market-reaches-137-9-billion-in-2018mobile-games-take-half. Acesso em: 8 nov. 2020.

WORLD METER. Current World Population. 2020. Disponível em: https://www.worldometers.info/world-population/. Acesso em: 21 nov. 2020.

ZACKARIASSON, P.; WILSON, T. L. The Video Game Industry: Formation, Present State, and Future. New York: Routledge, 2012.

ZEITHAML, V. A.; PARASURAMAN, A.; BERRY, L. L. Problems and Strategies in Services Marketing. Journal of Marketing, v. 49, n. 2, p. 33-46, 1 March 1985. Disponível em: https://doi.org/10.1177/002224298504900203. Acesso em: out. 2020.

ZINN, W.; JOHNSON, S. D. The Commodity Approach in Marketing Research: Is It Really Obsolete? Journal of the Academy of Marketing Science, v. 18, p. 345-353, 1 September 1990. Disponível em: https://doi.org/10.1177/009207039001800411. Acesso em: nov. 2020. 


\section{APÊNDICE 1: VERSÃO FINAL DO ROTEIRO DE ENTREVISTAS}

\section{BLOCO 1. INTRODUÇÃO}

Entrevistador: Olá, bom dia/boa tarde/boa noite! Meu nome é Walney. Sou aluno do Mestrado Profissional em Empreendedorismo da FEA USP. O objetivo desta entrevista é a realização de um estudo para minha dissertação de mestrado que visa a entender melhor de que forma as empresas desenvolvedoras de jogos digitais estão se relacionando com atividades de marketing. A empresa não será identificada e as respostas serão avaliadas em conjunto, não individualmente. Toda e qualquer informação será tratada sob absoluto sigilo e com um propósito estritamente acadêmico. Gostaria de solicitar a sua permissão para gravar a entrevista para fins de registro.

A entrevista dura cerca de 1 hora. Podemos começar?

BLOCO 2. APRESENTAÇÃO DO ENTREVISTADO, TRAJETÓRIA PROFISSIONAL E CARACTERÍSTICAS DA EMPRESA

Entrevistador: Conte-me um pouco sobre você e a sua empresa.

[EXPLORAR: Informações-chave a serem coletadas caso o respondente não as mencione em sua fala]

- Nome do entrevistado:

- Cargo:

- Departamento:

- Tempo de empresa:

- Empresa:

- País de origem da empresa:

- Quantidade de países em que atua:

- Tipos de jogos (mobile, PC ou console):

- Número aproximado de colaboradores:

- Histórico da empresa:

- Mercados em que atua:

- Colaboradores (quantos? Cargos?):

- Parceiros (quais?):

\section{BLOCO 3. PRINCIPAIS ATRIBUIÇÕES E DESAFIOS}

Entrevistador: Descreva os principais desafios que você está enfrentando e quais são suas principais responsabilidades atualmente.

[EXPLORAR: Questões-chave a serem realizadas caso o respondente não as mencione ao longo de sua fala]

- Quais são os objetivos de curto, médio e longo prazos da área?

- Quais as pessoas que definem esses objetivos? 
- Quais são suas responsabilidades e desafios?

- Quais são seus principais problemas enfrentados diariamente?

- Quais são suas metas?

- Quais são os recursos que você possui à disposição para realizar essas atividades?

- Quais são as principais atividades realizadas na prática, no dia a dia?

\section{BLOCO 4. ESTRATÉGIA DE MARKETING}

Entrevistador: Gostaria de entender melhor sua estratégia de marketing.

[EXPLORAR: Questões-chave a serem realizadas caso o respondente não as mencione ao longo de sua fala]

- Vocês definem uma estratégia de Marketing? Se sim, de que forma isso é feito?

- Como trabalham ações de promoção? [divulgação produtos/novos produtos, acompanhamento/controle das ações]

- Qual(is) o(s) perfil(s) do(s) seu(s) público(s) alvo? Como isso [perfil do público alvo] tem sido definido?

- De que forma o conhecimento do(s) público(s)-alvo influencia na decisão a ser tomada?

- De que forma vocês trabalham a monetização dos jogos? Quem participa dessa decisão de monetização?

- De que forma(s) a empresa se comunica nos meios digitais? Há planejamento prévio para cada ação? Na sua opinião, quais ações têm dado melhor resultado?

- Quais são os principais canais de comunicação utilizados na divulgação dos jogos e de que forma os mesmos são escolhidos?

- Como a comunicação com o player é feita em termos de mensagem, criativos e temas de campanha?

- Como vocês se posicionam enquanto marca?

\section{BLOCO 5. MERCADO: CONCORRÊNCIA, SEGMENTOS E PÚBLICO-ALVO}

Entrevistador: Gostaria de entender melhor o processo de entrada no mercado, definição e tratamento do público-alvo dos jogos a serem lançados.

[EXPLORAR: Questões-chave a serem realizadas caso o respondente não as mencione ao longo de sua fala]

- Quais são seus concorrentes diretos? Como vocês lidam com a concorrência? Existem estratégias específicas para jogos que disputam o mesmo público?

- Quais são as formas de contato / aproximação com o(s) público(s) alvo?

- Quais tipos de levantamento/ pesquisa vocês realizam?

- Qual a natureza e procedimentos (qualitativos, quantitativos) envolvidos na realização desses estudos?

- De que forma vocês lançam um jogo no mercado? como testam/ pré-testam os jogos ou projetos-piloto? 
[OBS: SUBSTITUIU “RELACIONAMENTO COM OS CLIENTES”, QUE PASSOU A SER O BLOCO 9, APÓS A PRIMEIRA ENTREVISTA]

Entrevistador: Agora eu gostaria de compreender melhor a forma como os jogos são produzidos na empresa. Quais são as principais decisões envolvidas para lançar um jogo novo no mercado?

[EXPLORAR: Questões-chave a serem realizadas caso o respondente não as mencione ao longo de sua fala]

- Como se decide que um jogo novo será lançado? Como e quem propõe uma nova ideia de jogo?

- No momento em que o jogo está sendo desenvolvido o que se leva em consideração para garantir seu sucesso de mercado?

- O que se define como um jogo de sucesso pela empresa?

- Quem participa dos testes? Jogadores reais ou profissionais/especialistas? Como essa dinâmica funciona?

- Quando o jogo já está no mercado, de que forma(s) as decisões sobre atualização são tomadas? São feitos, por exemplo, testes A/B para validar hipóteses de melhorias?

- Quais são as premissas de um bom jogo seguidas pela equipe para satisfazer o públicoalvo?

\section{BLOCO 7. PREÇO}

Entrevistador: Quero agora entender mais a fundo como vocês lidam com o aspecto financeiro do jogo. De que forma vocês tomam decisões relacionadas a custos e a retornos esperados do projeto do jogo?

[EXPLORAR: Questões-chave a serem realizadas caso o respondente não as mencione ao longo de sua fala]

- Como são tomadas as decisões de investimento? Quanto, quando e como gastar a verba?

- De onde vem os principais recursos financeiros da empresa?

- Como o retorno sobre esse investimento é projetado?

- Qual é o modelo de monetização mais utilizado nos jogos da empresa?

- Por quais motivos esse é o modelo mais popular?

- Como pensam/ definem precificação? De que forma(s) isso tem sido feito?

\section{BLOCO 8. PRAÇA}

Entrevistador: Agora gostaria de compreender melhor a distribuição dos jogos criados: quais são as principais plataformas utilizadas e quais as principais decisões envolvidas nesse processo?

[EXPLORAR: Questões-chave a serem realizadas caso o respondente não as mencione ao longo de sua fala]

- Como avaliam/ acompanham o "match" entre plataforma escolhida e player target?

- Qual é a principal plataforma de distribuição que vocês utilizam? 
- Quais são os recursos utilizados para relacionamento com os players?

- Como ocorre a gestão das plataformas utilizadas para distribuição? Quantas pessoas/ equipes se dedicam a isso?

\section{BLOCO 9. PROMOÇÃO}

Entrevistador: Como os jogos são divulgados?

[EXPLORAR: Questões-chave a serem realizadas caso o respondente não as mencione ao longo de sua fala]

- Como é realizado o planejamento de mídia? Quem participa dessas decisões?

- Quais são os principais meios de comunicação utilizados?

- Com base em quais premissas ou estratégias as peças de comunicação são criadas?

- Como avaliam/realizam/ acompanham os KPIs de campanha?

\section{BLOCO 10. RELACIONAMENTO COM OS CLIENTES}

Entrevistador: Agora eu gostaria de compreender o relacionamento com os players dos jogos da empresa (jogadores que estão na "base"). De qual(is) forma(s) a empresa se relaciona com seus players?

[EXPLORAR: Questões-chave a serem realizadas caso o respondente não as mencione ao longo de sua fala]

- Quais as ferramentas, meios ou recursos utilizados para se relacionar com os jogadores da base?

- Como vocês trabalham para responderem a demandas, críticas ou solicitações desses jogadores? (Régua de relacionamento? Disparo automático de ações por eventos tagueados? CRM? etc.).

- De qual(is) forma(s) vocês se relacionam com seus jogadores? [Explorar: se utilizam fóruns, comunidades online externas à empresa]. De que forma essa relação é estabelecida?

\section{BLOCO 11. INTELIGÊNCIA DE MARKETING}

Entrevistador: Agora gostaria de compreender melhor como vocês trabalham com os dados para realização de análises e reports para melhorarem a experiência com os players.

[EXPLORAR: Questões-chave a serem realizadas caso o respondente não as mencione ao longo de sua fala]

- Quais são as principais fontes de dados utilizadas pela empresa?

- Como armazenam e organizam esses dados?

- Quais tipos de análises fazem com esses dados? Com qual periodicidade? Por quê?

- Quais são as principais finalidades dessas análises?

- Quais tipos de reports utilizam para acompanhamento de performance do jogo? 
- Quais são os principais indicadores de sucesso do jogo que são acompanhados durante e após seu lançamento?

- Vocês aproveitam dados de jogos já lançados para novos lançamentos? Se sim, de que forma esse processo ocorre?

- Qual é o nível de dificuldade de interpretação dos reports? Eles são visualmente atrativos e simples ou de difícil interpretação?

- Qual é o nível de automatização das análises e dos reports gerados?

\section{BLOCO 12. PERSPECTIVAS PARA A EMPRESA E PARA O MERCADO}

Entrevistador: Você poderia descrever, com base em sua opinião, um cenário ideal de maturidade em Marketing para alavancar os resultados da empresa na qual você trabalha?

[EXPLORAR: Questões-chave a serem realizadas caso o respondente não as mencione ao longo de sua fala]

Quais as perspectivas futuras para o segmento de games? Quais as perspectivas futuras para o seu negócio/ a sua empresa?

\section{BLOCO 13. DADOS ADICIONAIS E AGRADECIMENTO}

- Faturamento anual aproximado ou porte:

- Indicação de outras pessoas: 


\section{APÊNDICE 2: CARTA-BASE DE CONVITE ENVIADA À AMOSTRA SELECIONADA}

[A depender do entrevistado e das circunstâncias, o texto era modificado para personalização, conforme descrito em 4.4.2 Abordagem dos Potenciais Entrevistados]

\section{Assunto: [Convite] estudo USP sobre games}

Olá [XXXXXXX], tudo bem?

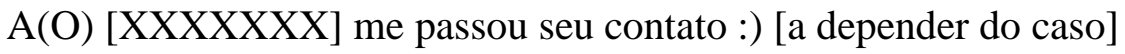

Meu nome é Walney Barbosa e sou aluno do Programa de Mestrado Profissional em

Empreendedorismo da Faculdade de Economia e Administração da Universidade de São Paulo (FEA-USP).

Estou conduzindo uma pesquisa para a minha dissertação com profissionais que possuem uma reconhecida experiência no mercado de Jogos Digitais.

Como parte do meu projeto, gostaria de convidá-lo(a) para uma entrevista online que dura em torno de 1 hora (via Google Meet). As análises serão realizadas de forma agregada e nenhum dado individual será divulgado. $\mathrm{O}$ projeto possui finalidade exclusivamente acadêmica.

Caso eu possa contar com sua participação, como retribuição você receberá um sumário executivo exclusivo com as principais conclusões do estudo, além de poder ter acesso à minha dissertação na íntegra, quando a mesma for concluída.

Você teria algum horário disponível nos próximos dias? Você poderia me passar alternativas que, com muito prazer, procurarei me adaptar à sua agenda:)

Caso queira, eu e minha orientadora estamos à sua disposição para quaisquer dúvidas. Meu email é: walney.reis@usp.br e o da Profa. Dra. Jane Marques é: janemarq@usp.br.

Muito obrigado, desde já!

W. 